Andrews University

Digital Commons @ Andrews University

\title{
A Study Of The Pokot Cultural Worldview: Missiological Implications For Seventh-Day Adventist Witness Among The Pastoral Nomads Of Kenya
}

Haron Matwetwe

Andrews University, matwetwe@andrews.edu

Follow this and additional works at: https://digitalcommons.andrews.edu/dissertations

Part of the Missions and World Christianity Commons

\section{Recommended Citation}

Matwetwe, Haron, "A Study Of The Pokot Cultural Worldview: Missiological Implications For Seventh-Day Adventist Witness Among The Pastoral Nomads Of Kenya" (2017). Dissertations. 1643.

https://digitalcommons.andrews.edu/dissertations/1643

https://dx.doi.org/10.32597/dissertations/1643

This Dissertation is brought to you for free and open access by the Graduate Research at Digital Commons @ Andrews University. It has been accepted for inclusion in Dissertations by an authorized administrator of Digital Commons@Andrews University. For more information, please contact repository@andrews.edu. 


\begin{abstract}
A STUDY OF THE POKOT CULTURAL WORLDVIEW: MISSIOLOGICAL IMPLICATIONS FOR SEVENTH-DAY ADVENTIST WITNESS AMONG THE PASTORAL NOMADS OF KENYA
\end{abstract}

by

Haron Nyamweya Matwetwe

Adviser: Wagner Kuhn 


\title{
ABSTRACT OF GRADUATE STUDENT RESEARCH
}

\author{
Dissertation \\ Andrews University \\ Seventh-day Adventist Theological Seminary
}

\section{Title: A STUDY OF THE POKOT CULTURAL WORLDVIEW: MISSIOLOGICAL IMPLICATIONS FOR SEVENTH-DAY ADVENTIST WITNESS AMONG THE PASTORAL NOMADS OF KENYA}

Name of the researcher: Haron Nyamweya Matwetwe

Name and degree of faculty adviser: Wagner Kuhn, $\mathrm{PhD}$

Date completed: September 2017

Seventh-day Adventist witness among the nomadic peoples of the East Africa region is faced with a number of challenges. Although the Church enjoys relative success in reaching most communities, its growth and development appears restricted to locations occupied by the settled communities. Unfamiliarity with nomads' cultural structures and values is partial explanation for why missionaries have failed to effectively connect with the nomads thereby hampering the establishment of a more vibrant mission work in pastoral nomadic regions.

This qualitative research sought to describe the Pokot cultural worldview as a step toward understanding their socio-cultural context and identify barriers to effective mission. This is fundamental in developing missional bridges that would potentially close 
the gap between the Church and the pastoralists. Using an ethnographic approach, data collected using focus-group interviews, participant observation, artifact examination, and casual dialogue enabled the description of the Pokot cultural worldview and exposed their cognitive, evaluative and affective assumptions of their culture.

The study reveals that although they are closely associated culturally with other Nilotic groups in East Africa, the Pokot are a distinct community with an exciting historical heritage and shared value systems. A high regard for communal life and rigorous religious practices and customs are among values characteristic of the people. In their communal living, group-thinking and decision-making above individual pursuits is fundamental. Rather than focusing on the individual, the Pokot emphasize the development and maintenance of relationships with others. Life and thought are centered on the group rather than on the individual or things. Every member of the community is expected to demonstrate loyalty and respect to their parents, older siblings, elders, age mates and friends. Among the benefits of communal living is the sense of belonging, respect for relationships, and cooperation and strength of the whole society against the outside world.

On the other hand, religion plays a key role in life among the Pokot. Each step of life, from birth to death (or even after death), is marked with some form of religious practice or ritual involving sacrifice, prayers, song and dance, or bowing in holy places. Worship in caves, on mountains, at river-banks, under trees, and at other sacred places where divine beings are presumed to inhabit is common. Their religious ceremonies are characterized by charismatic singing, dancing, chanting, jumping, and other forms of expressive passion that appease the deity. 
The pacification of the supreme being, tororot, and his assistants: asis, who witnesses human activities on earth, ilat, the messenger of the deities to humans, and the ancestral spirits is commonly practiced to alleviate calamity in the form of drought, disease, or death. Prayers in the form of songs are offered, entreating divine intervention for the protection of livestock and people, for more healthy calves to be born, and for enemies and wild animals to be kept away from the land.

Other valued customs include acts of heroism, generosity, respect, trust, bravery, wealth, versatility, and high moral standards. From early ages, younger people are groomed and expected to be loyal, patriotic, respectful, brave, and morally upright members of the community. The concept of poghishyo (peace and harmony) requires that people should aspire to live united if blessings in the form of rain, health, and enough food is to be expected from tororot. Initiation of young people into various stages of life helps to train, educate, and test their bravery and loyalty to authority, which is essential for unity and survival of the Pokot people in the midst of a region marked with scrambling of scarce natural resources.

In response to these findings, a comprehensive model for mission was developed. The model examined seven key strategies to guide mission initiatives that will result in the formation and development of mature Christians whose faith and practice is biblically based and spiritually guided.

First, worldview transformation is a topmost approach. Forming mature Christians from unbiblical backgrounds who will be able to witness to others require that a biblical worldview be developed from the initial stages of witnessing. This helps to alleviate unorthodox practices such as superficial surface-level conversion, minimal 
behavior modification, syncretistic practices, and dual allegiance, which are often results of improper witness related to a lack of worldview change. Through the development of strong social relationships with converts, providing Bible studies, communicating in culturally appropriate methods, and overcoming negative attitudes toward the nomads, missionaries are likely to win nomads' trust, enabling the development of a Christian worldview.

Second, a contextualized ministry is vital. Contextualization requires that nomads should hear and respond to the Word of God in their cultural setting. This can only be possible if the communication of the gospel is done through the use of cultural methods such as stories, songs, proverbs, sayings, and riddles. A contextualized ministry should also involve the establishment of congregational structures that are compatible with a nomadic life. Since periodic migration is central to the pastoralists' life, creating nomadic churches and training of missionaries who can provide ministry in nomadic contexts is imperative.

The third strategy is appropriate communication. Sharing the gospel in culturally appropriate ways is imperative for quality and fruitful Christian mission and ministry. Since meaning is often formed and largely influenced by how and what people communicate, the use of familiar methods of transmitting the gospel is necessary. Oral methods such as proverbs, stories, and songs, with which the pastoralists are familiar are vital avenues that will enable nomads to hear and respond to the gospel in what is now termed "heart language." A specialized ministry that focuses on nomads is fourth. The study showed that nomadic contexts are unique in comparison to settled environments where Christianity is better established and from which most missionaries originate. 
Specialization will likely benefit ministry as it would enable the recruitment, training, and mobilization of a skilled workforce. It would also ensure that mission resources are better managed and channeled.

Fifth is the incarnational ministries. Response to felt needs among pastoralists is a significant approach that would help to create bridges for sharing the gospel. Since poverty, disease, and limited sources of water are among the many challenges nomads face, Christians can address these pressing needs through specific ministries such as initiating self-help projects, operating health centers, constructing wells, among other initiatives. These, will provide needful solutions and empower the nomads in their daily lives.

Sixth, a prayer strategy is also of utmost importance. It is obvious that human efforts, without divine intervention, are insufficient when witnessing to people grounded in unbiblical worldviews. Mission workers will need to be guided and energized by divine power in order to know the what, when, and how to share the gospel. The strategy also challenges those who are not directly involved to intercede for divine intervention on behalf of missionaries and their targets for success to be achieved.

Finally, there is need for a group-oriented approach to evangelism among nomads. Their communal thinking requires that missionaries must recognize nomads' social structures by approaching them as a group rather than as individuals. Since the community elders are the spokesmen of the community, those engaged in various mission initiatives should seek the elders' permission, or at least notify them of Christian projects in their community. 
Andrews University

Seventh-day Adventist Theological Seminary

\title{
A STUDY OF THE POKOT CULTURAL WORLDVIEW: MISSIOLOGICAL IMPLICATIONS FOR SEVENTH-DAY ADVENTIST WITNESS AMONG THE PASTORAL NOMADS OF KENYA
}

\author{
A Dissertation \\ Presented in Partial Fulfillment of \\ the Requirements for the Degree \\ Doctor of Philosophy
}

by

Haron Matwetwe

September 2017 
(C) Copyright by Haron Nyamweya Matwetwe 2017 All Rights Reserved 


\title{
A STUDY OF THE POKOT CULTURAL WORLDVIEW: MISSIOLOGICAL IMPLICATIONS FOR SEVENTH-DAY ADVENTIST WITNESS AMONG THE PASTORAL NOMADS OF KENYA
}

\author{
A dissertation \\ presented in partial fulfillment \\ of the requirements for the degree \\ Doctor of Philosophy
}

by

Haron Matwetwe

\section{APPROVAL BY THE COMMITTEE:}

Faculty Adviser, Wagner Kuhn

Professor of World Missions and Intercultural Studies

Bruce L. Bauer

Professor of World Missions

Gorden R. Doss

Professor of World Missions

Boubakar Sanou

Assistant Professor of World

Mission and Christian Leadership
Director of PhD/ThD Religion Program Thomas Shepard

Dean, SDA Theological Seminary

Jiří Moskala 


\section{TABLE OF CONTENTS}

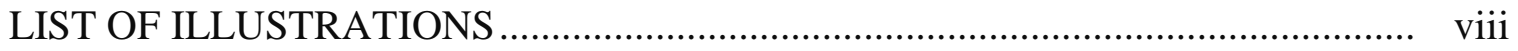

LIST OF TABLES ................................................................................. viii

LIST OF ABBREVIATIONS ..................................................................... ix

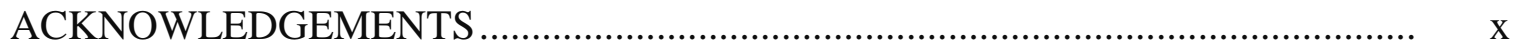

Chapter

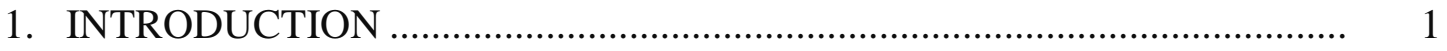

Background of the Study ................................................................. 1

Statement of the Problem................................................................. 8

Purpose of the Study ........................................................................ 8

Research Questions .............................................................................. 8

Significance of the Study .................................................................. 9

Conceptual Framework ..................................................................... 9

Methodology ................................................................................ 11

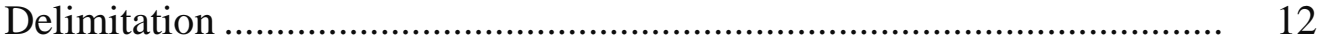

Limitations ...................................................................................... 13

Chapter Outline ............................................................................... 13

2. A THEORETICAL GROUNDING FOR MISSION: WORLDVIEW, NOMADS, AND SCRIPTURE ........................................................... 15

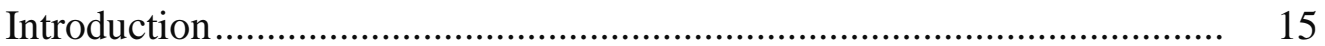

Worldview................................................................................ 16

Definition of Worldview ................................................................. 18

Dictionary Definition .................................................................. 18

Social Sciences Definition ........................................................ 19

Worldview Functions ........................................................................ 21

Worldview and Christian Mission ....................................................... 24

For Authentic Transformation .................................................. 26

For Effective Communication.......................................................... 27

For Contextualization................................................................. 28

To Create Respect for Culture ....................................................... 29

Nomadic Cultures ............................................................................ 29

Definition of Nomads ................................................................. 30

Types of Nomads ....................................................................... 31 
Population and Geographical Locations ................................................. 33

Examples of Nomads ..................................................................... 34

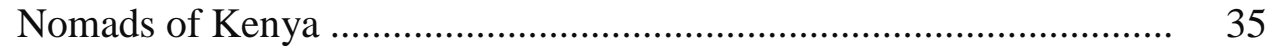

Christian Mission among East Africa Nomads........................................... 36

Nomads in Scripture ......................................................................... 37

A Nomadic God ........................................................................... 38

Calling Nomads unto Salvation ....................................................... $\quad 38$

Called for Mission......................................................................... 40

Protected by God............................................................................ 40

"Wandering," a Biblical Imagery ...................................................... 41

Mission and Nomads.............................................................................. 42

Motivation for Mission ................................................................... 43

Adventist Mission and Nomads .......................................................... 44

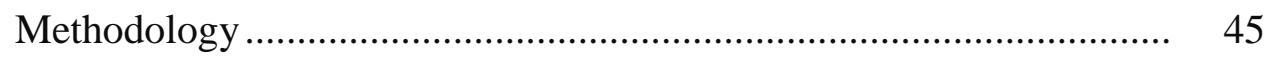

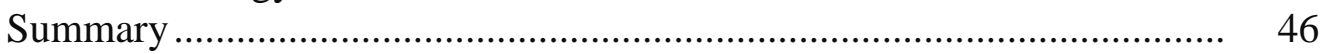

3. SOCIO-CULTURAL ANALYSIS OF THE POKOT ...................................... 48

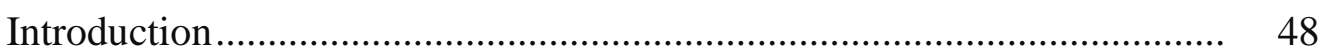

Migration and Settlement of Kenyan Peoples .......................................... 48

Previous Research on the Pokot............................................................. 50

Geographical Locations ................................................................... 55

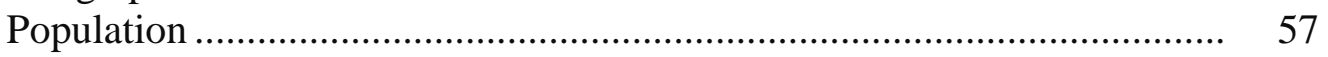

Origins and Historical Development ………………………………... $\quad 58$

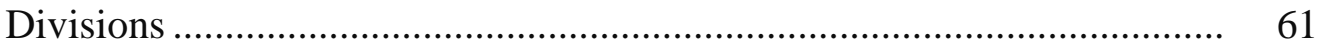

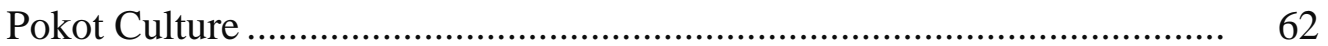

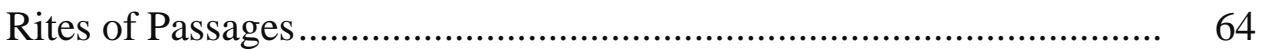

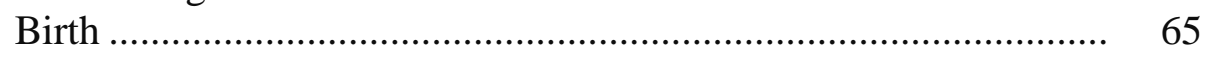

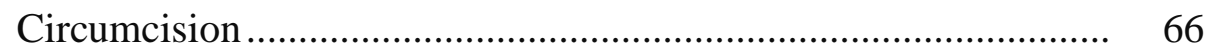

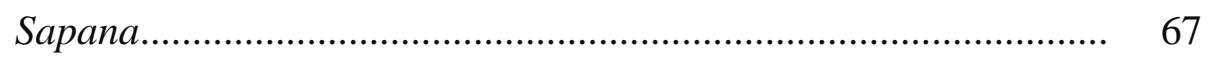

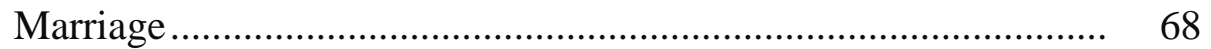

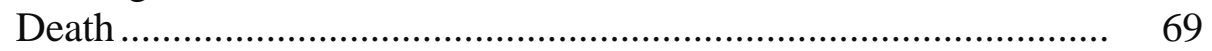

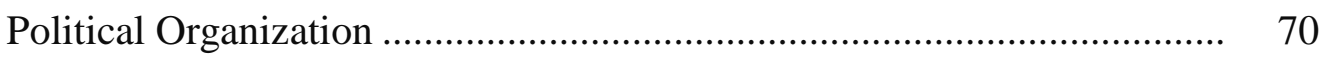

Economic Organization .................................................................... 71

Livestock Farming …………………………………................. 72

Crop Farming .......................................................................... 73

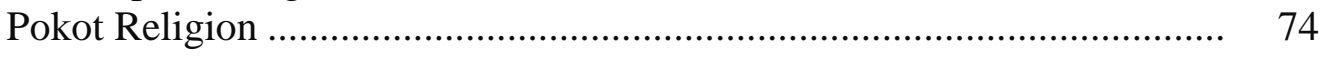

Religious Practices ......................................................................... 74

The Divine ……..................................................................... 75

Religious Officers ..................................................................... 76

Social Organization...................................................................... 77

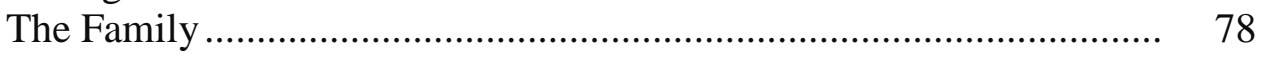

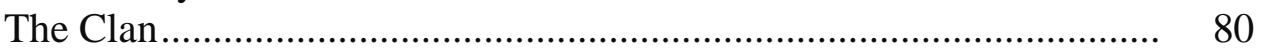

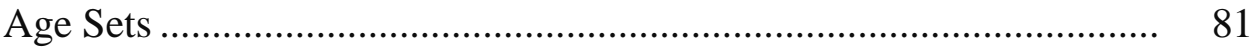

Christian Mission among the Pokot ............................................................ 82

Early Protestant Mission ................................................................. 82 
Catholic Mission .......................................................................... 83

Seventh-day Adventist Mission ....................................................... 84

Evangelism Methods.................................................................... 85

Health .......................................................................... 85

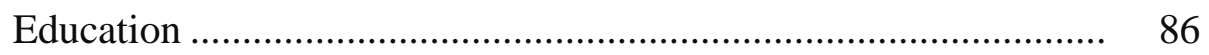

Global Mission Pioneers ........................................................... 86

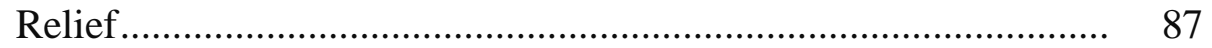

Construction of Churches ........................................................ 88

Advocacy for Peace ………………..................................... 88

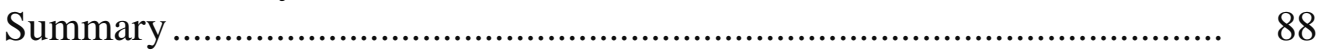

4. ETHNOGRAPHY OF THE POKOT: RESEARCH FINDINGS ...................... 90

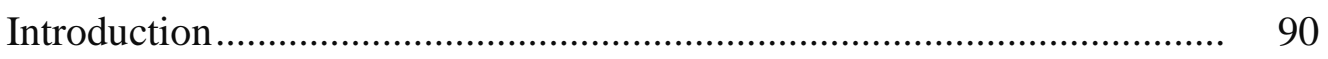

Qualitative Research Design .................................................................. $\quad 90$

Ethnographic Approach .................................................................. 91

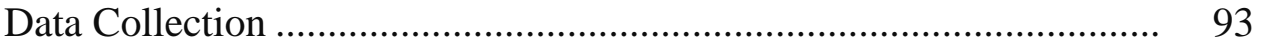

Participant Observation............................................................. 93

Interviewing ....................................................................... 94

Artifact Examination................................................................. 94

Casual Dialogue .................................................................... 95

Purposive Sampling ………………………………………........ 95

Ethical Considerations .................................................................... 96

Transcription and Analysis ............................................................. 96

Data Collection Procedures.............................................................. 98

Oral Interviews (Part 1) ………………………..................... 98

Artifact Examination............................................................... 98

Cognitive Themes ..................................................................... 99

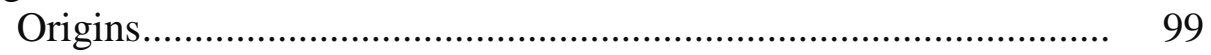

Time

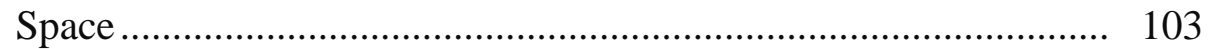

Destiny ................................................................................. 104

Individual/Group/Others ......................................................... 106

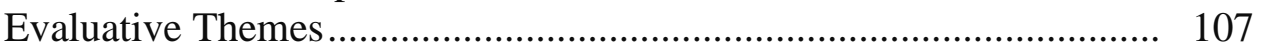

Pokot Heroes/Heroines ............................................................... 107

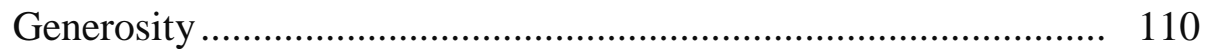

Respect and Trust................................................................. 111

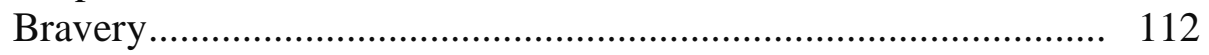

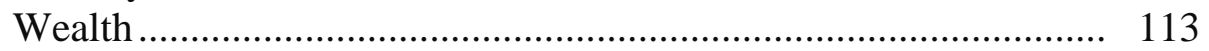

Versatility ........................................................................ 114

Premarital Purity .................................................................. 115

Affective Themes ....................................................................... 116

Expressive Culture ................................................................ 116

Fear of Spirits ....................................................................... 117

Orality ...................................................................... 118

Oral Interview (Part 2) ................................................................... 119 
Findings Generated by Interviews of Church Officers ..................... 121

Unreached Regions ......................................................................... 121

Inapt Mission Methods .................................................................. 123

Inadequate Missionaries......................................................... 124

Nomadism ................................................................... 125

Poor Communication ................................................................ 126

Analyses and Missiological Implications ........................................... 127

Traditional Religious Beliefs ..................................................... 128

Socio-economic Needs.......................................................... 132

Communication Tasks .............................................................. 134

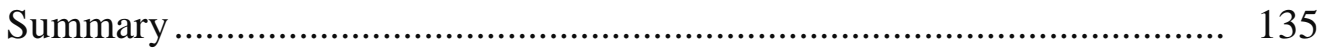

5. A MODEL FOR MISSION AND MINISTRY IN LIGHT OF THE POKOT CULTURAL WORLDVIEW: MISSIONAL RESPONSES............. 137

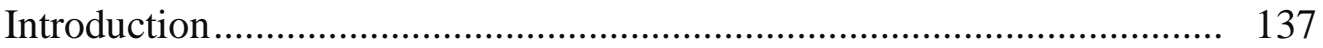

The Need for a Mission Model ........................................................... 138

A Comprehensive Approach ........................................................... 142

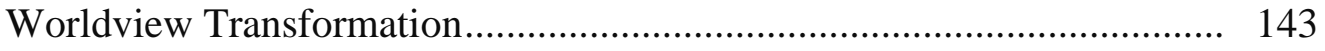

Reasons for Worldview Transformation........................................ 144

Methods for Worldview Transformation ........................................... 146

Developing Strong Relationships ........................................... 147

Bible Studies .................................................................... 148

Storytelling .................................................................. 149

Overcoming Negative Attitudes ............................................ 151

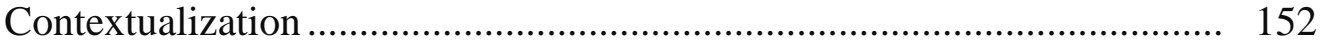

Critical Contextualization ........................................................... 152

A Contextualized Ministry for Nomads.......................................... 154

A Contextualized Theology ................................................ 155

Training Nomadic Theologians and Pastors ............................... 156

Nomadic Churches ............................................................. 157

Communicating with Nomads ........................................................ 159

Foundations of Christian Communication ...................................... 159

Challenges of Effective Communication ....................................... 160

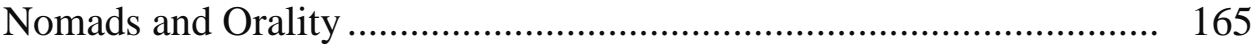

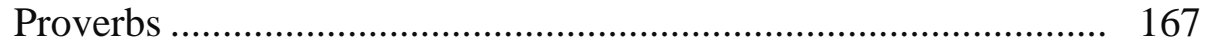

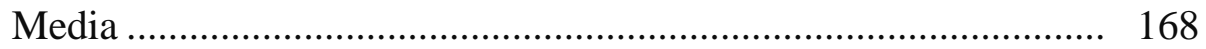

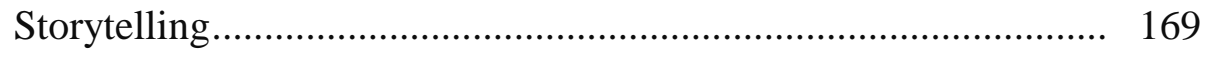

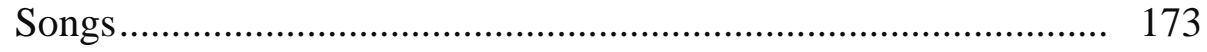

Redemptive Analogies ........................................................ 176

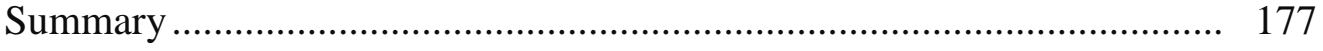

6. WITNESSING TO THE NOMADS: STRATEGIC RESPONSES ............... 179

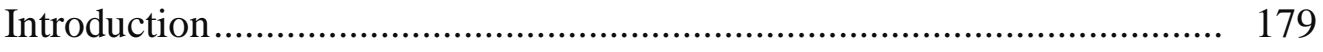

Specialization Strategy ............................................................ 180 
Biblical, Historical, and Contemporary Mandates ........................... 181

Importance of Specialization ..................................................... 183

Incarnational Ministry................................................................... 184

Foundations of Incarnation Motif ............................................... 185

Principles of Incarnation .............................................................. 186

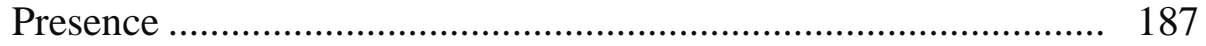

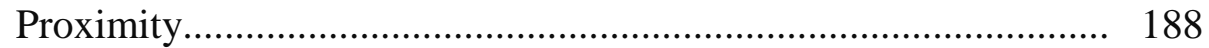

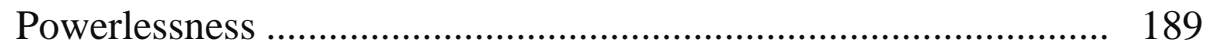

Proclamation ..................................................................... 190

The Prayer Strategy...................................................................... 191

Biblical and Historical Mandates for Prayer................................... 191

Challenges Necessitating Prayer..................................................... 193

Praying as Spiritual Warfare ......................................................... 194

Prayer for Openness and Receptivity.......................................... 194

Praying for Missionaries .......................................................... 195

Group Focused Evangelism .......................................................... 197

Summary .......................................................................... 201

7. SUMMARY, RECOMMENDATIONS, CONCLUSIONS ........................ 202

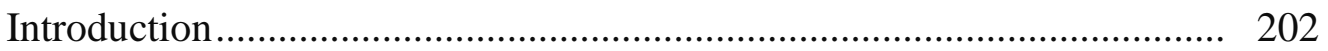

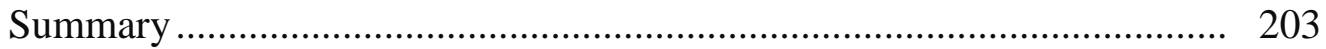

Nomadic Cultures .................................................................. 204

The Pokot Worldview ............................................................... 205

A Comprehensive Approach ....................................................... 206

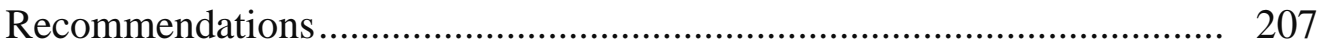

Conclusions ............................................................................. 209

Appendix

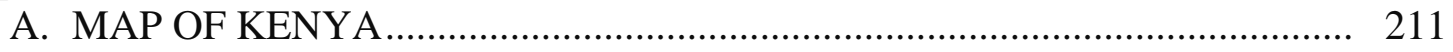

B. POPULATION DISTRIBUTION OF KENYA'S NOMADS ..................... 212

C. CAMPLE INTERVIEW PROTOCOLS ................................................ 213

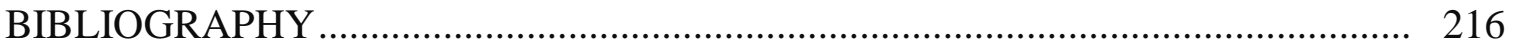

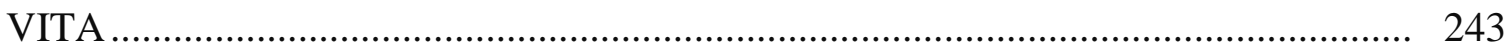




\section{LIST OF ILLUSTRATIONS}

1. Map of Kenya Showing West Pokot County............................................... 56

2. Pokot Milk Pail and Food Bowl ............................................................... 105

3. Pokot Walking and Defense Stick .......................................................... 111

4. The Pokot Pillow Chair ................................................................................... 114

5. The Pokot Non-bent Stick ................................................................. 115

6. Summary of Missiological Implications.................................................... 128

\section{LIST OF TABLES}

1. Worldview Dimensions and Themes........................................................... 97

2. Summary of Pokot Worldview Themes .................................................. 120 


\section{LIST OF ABBREVIATIONS}

ACNT An American Commentary on the New Testament. Edited by Alvah Hovey. Philadelphia, PA: American Baptist, 1881.

$\begin{array}{ll}\text { AFM } & \text { Adventist Frontier Missions } \\ \text { BCMS } & \text { The Bible Churchmen's Missionary Society } \\ \text { BI } & \text { The Biblical Illustrator. Edited by Joseph S. Exell. Grand Rapids, MI: } \\ \text { Baker Books, 1954. } \\ \text { BMW } & \text { Bicycle Missionary to the World } \\ \text { FGM } & \text { Female Genital Mutilation } \\ \text { GMP } & \text { Global Mission Pioneers } \\ \text { HBD } & \text { HarperCollins Bible Dictionary, condensed ed. Edited by Mark A. Powell. } \\ \text { NIV } & \text { Hew York: HarperCollins, 2009. } \\ \text { MVUA } & \text { Missionary Volunteers to Unentered Areas } \\ \text { NIB } & \text { The New Interpreter's Bible. 12 vols. Nashville, 1994. } \\ \text { NIV } & \text { The New International Version Bible. Grand Rapids, MI: Zondervan, } \\ & \text { 2011. } \\ & \text { Seventh-day Adventist Church }\end{array}$




\section{ACKNOWLEDGMENTS}

Completing a study of this magnitude is a task no individual can accomplish single handedly. I am thus deeply grateful to special individuals who enabled me to successfully complete the requirements and attain the purpose of this study. Apart from

providing materials necessary for the study, these persons gave moral support throughout a process that was rigorous and time consuming and also offered prayers and words of encouragement that motivated me to carry on.

First, I express my gratitude to Almighty God from whom all blessings flow. It was by God's grace and mercy that I was protected, encouraged, and provided with the tools that were necessary for this project.

Second, I am grateful to my dear wife, Deborah, and our children, Hannah, Huldah, and Zachary. They gave me ample time, sacrificed their comfort, and bore patiently with me as I was engrossed in the writing process. My brothers James Matwetwe and Kefa Matwetwe also were helpful. James connected me with my research informant while Kefa assisted me financially to attend Andrews University.

I recognize the faculty of Andrews University World Mission department who played a significant role in this study. The dissertation committee composed of Dr. Kuhn, Dr. Bauer, and Dr. Doss helped to perfect this work to meet required standards. My dear friend Dr. Sanou is also remembered for his continual and timely encouragement through prayer that came when the drive for writing was weaning. On the same note, I 
acknowledge Charissa Boyd and Linda Bauer for their editorial service. Their contribution enabled this work to meet a rightful standard.

I am also grateful to Pastor Joseph Lemokel, my informant, and the research crew in Pokot. Joseph helped me to organize the interview focus groups, offered translation of interview materials, and sacrificed his time to accompany me to various places of study. I also appreciate the generosity of the staff at Chepararia SDA Clinic. They opened their doors for me to stay for the period I spent in Pokot.

The officers of West Kenya Union Mission of Seventh-day Adventists are greatly appreciated. Pastor Maena provided timely permission, allowing me to conduct research within the Union territory. I also appreciate those who agreed to participate in the interviews - pastors Girimbe and Wanyonyi, and Elder Parklea.

Finally, I applaud the people of Chepararia, Sigor, and Kapenguria villages. They welcomed me into their homes, shared greetings, provided company, and were friendly throughout my stay among them. 


\section{CHAPTER 1}

\section{INTRODUCTION}

This dissertation is a study of the cultural worldview ${ }^{1}$ of the Pokot, a pastoral nomadic community ${ }^{2}$ of Western Kenya. By seeking to understand them at deeper worldview levels, the research aims to facilitate a more effective Seventh-day Adventist (SDA) mission strategy among these and other pastoralists in the East African region.

\section{Background of the Study}

Scripture presents Old Testament patriarchs as nomads who were followers of Yahweh. They were not only depositories of the knowledge of God in the midst of heathen nations but were also keepers of God's Word and heralds of the Messianic promise. ${ }^{3}$ Nomadic patriarchs such as Abraham, Isaac, Jacob, and Moses were custodians of God's statutes despite a lifestyle that demanded constant movement (Gen. 12; 26; Heb.

\footnotetext{
${ }^{1}$ A concept that describes deep levels of culture that includes peoples' beliefs and assumptions about the world around them and which they use to order their lives. See Paul G. Hiebert, Transforming Worldviews: An Anthropological Understanding of How People Change (Grand Rapids, MI: Baker Books, 2008), 25. See also Charles H. Kraft, Anthropology for Christian Witness (Maryknoll, NY: Orbis Books, 2004), 52.

${ }^{2}$ The three main types of nomads differentiated by their means of subsistence are the pastoralists, the hunter-gatherers, and the peripatetics. The pastoralists, who are the focus of this study, base their culture and subsistence on keeping domestic animals and seeking pasture for them. A description of the other nomadic types is given in chapter 2. See also David J. Phillips, Peoples on the Move: Introducing the Nomads of the World (Pasadena, CA: William Carey Library, 2004), 8.

${ }^{3}$ Gerhard Von Rad, Old Testament Theology: The Theology of Israel's Traditions (Louisville, KY: Westminster John Knox Press, 2001), 175.
} 
11:9-14). ${ }^{4}$ Part of the New Testament narrative also includes itinerant shepherds, moving their sheep from place to place in search of pastures and safeguarding the flock at night. These shepherds became the first recipients and bearers of the news about the birth of Jesus in Bethlehem (Luke 2:8-20). ${ }^{5}$

As believers grew in faith and developed a stronger relationship with God in successive generations, culture partly shaped the believers' religious expressions. Andrew F. Walls, who argues that culture is the workplace of Christian theology, ${ }^{6}$ presents a historical panorama, which suggests that the religion once practiced by the Old Testament nomadic patriarchs and the New Testament shepherds, gradually became identified with a settled lifestyle through cultural influences ${ }^{7}$ particularly through the principle of translatability. ${ }^{8}$

The Renaissance, the Industrial Revolution, and the introduction of the printing press gave birth to Western civilization and a new approach to all spheres of life

${ }^{4}$ All scriptural quotations are from the New International Version (NIV) unless otherwise stated.

${ }^{5}$ George R. Bliss, Commentary on the Book of Luke, An American Commentary on the New Testament (ACNT), ed. Alvah Hovey (Philadelphia, PA: American Baptist, 1881), 46-49; Mark Allan Powel, "Shepherds," HarperCollins Bible Dictionary (HBD), condensed ed. (New York: HarperCollins, 2009).

${ }^{6}$ Andrew F. Walls, The Missionary Movement in Christian History: Studies in the Transmission of Faith (Maryknoll, NY: Orbis Books, 2006), 146.

${ }^{7}$ Ibid., 16-25. Walls analyzes six phases of Christian history, noting that in each phase, expression of the Christian faith took an impress from the existing culture. In the Barbarian or third phase of Christian history for example, a new creation of Christianity that was less conditioned by the city-based literary, intellectual, and technological tradition of the Hellenistic-Roman phase developed. Expression of faith was constrained more by the circumstances of peasant cultivators and their harsh, uncertain lives. By the turn of the Western Europe phase, identity of the individual as an independent unit had developed. Christian faith became a matter of individual decision and application in contrast to the communal decision and mass response that characterized the barbarian Christianity.

${ }^{8}$ Ibid., 16-40. Translatability of the Christian faith describes how culture influences the process through which believers have historically responded to Christ within their cultural setting. See Ibid., 29. 
including the study of theology. ${ }^{9}$ Modern Christian mission frameworks such as the mission station that was predominant within the nineteenth century missionary movements in some regions ${ }^{10}$ came into existence. These mission developments fostered a philosophy of having converts settle in or near mission centers where they were nurtured into mature Christians and sent out as witnesses. ${ }^{11}$ Although in Africa the mission stations became administrative and educational centers while believers remained in their villages, ${ }^{12}$ the settled environment continued to remain a more convenient and effective context for mission work than nomadic settings.

The convenience of settled settings for mission work is more apparent for the SDA Church in Kenya. Church growth and development studies ${ }^{13}$ demonstrate that the Church has more often succeeded in evangelizing settled communities ${ }^{14}$ than nomads.

\footnotetext{
${ }^{9}$ Paul R. Spickard and Kevin M. Cragg, A Global History of Christians: How Everyday Believers Experienced Their World (Grand Rapids, MI: Baker Books, 2008), 146-69; 280-302.

${ }^{10}$ Donald A. McGavran, The Bridges of God (London, UK: World Dominion Press, 1955), 48-67.

${ }^{11}$ Donald A. McGavran, Understanding Church Growth (Grand Rapids, MI: William B. Eerdmans, 1990), 278-89.

${ }^{12}$ George G. Hunter III, “The Legacy of Donald A. McGavran," International Bulletin of Missionary Research, no. 4 (October 1992), 159. Mission stations were generally developed as first-stage exploratory witnessing activities with the intention of larger conversions in later times. Analysts indicate that wherever the in-gatherings did not occur, mission stations became the end and the mission experience was relegated to secondary purposes such as education, medicine, and relief-work. In this new paradigm shift, missionaries engaged themselves in activities with which they were more familiar and could see results, recruitment of mission workers was for individuals who could perpetuate the new focuses, and maintaining mission stations became the dominant agenda while churches remained primarily peripheral.

${ }^{13}$ Nehemiah M. Nyaundi, Religion and Social Change: A Sociological Study of Seventh-day Adventism in Kenya (Lund, Sweden: Lund University Press, 1993). Other studies include Clyde Morgan's East-Central Africa Unreached Assessment Report conducted in 2010. Nyaundi's study from a sociological perspective is the most comprehensive that details evangelism methods, expansion trajectories, and analyses of the impact of Adventism on Kenyan society.

${ }^{14}$ These are communities with permanent properties such as houses and land. Their economic survival does not require periodic movement or resettlement to other regions as with the nomads.
} 
Soon after evangelistic activities began among the ethnic groups of Western Kenya in 1906, significant progress was achieved, and the SDA work advanced toward Central Kenya and later toward the coast of the country. ${ }^{15}$ Over the years, progress was achieved with congregations composed of adherents from various communities of the Nyanza, Western, and the Coastal counties with an estimated membership of over 650,000 as of $2015 .{ }^{16}$

While this growth is a desirable and positive development, a dichotomy exists in the nature of its progress. The growth and the impact of Adventism on Kenyan society indicate that although the Church has been in Kenya for over a century, it is still largely restricted to the regions that are inhabited by settled communities. ${ }^{17}$ The Northern and Rift valley counties, which are home to significant populations of pastoral nomadic communities including the Pokot, are mostly unreached (see Appendixes A and B).

Apart from the early trends of the SDA Church in Kenya described above, mission researches by groups such as The Joshua Project also reveal that the Pokot and other nomadic pastoralists are among the least reached people groups in the world. ${ }^{18}$ These studies show that Kenyan pastoralists are still largely without the gospel and church membership in some of their populations is non-existent. A study by Clyde

\footnotetext{
${ }^{15}$ Seventh-day Adventist Encyclopedia (Washington, DC: Review and Herald, 1976), s.v. "Kenya."

${ }^{16}$ SDA Church, General Conference Office of Archives, Statistics and Research, accessed October 17, 2016, http://www. adventiststatistics .org/view_Summary.asp?FieldInstID=2066644.

${ }^{17}$ Nyaundi, Religion and Social Change; Clyde Morgan, "East-Central Africa Division Unreached Assessment Report," unpublished manuscript, April 22, 2010.

${ }^{18}$ The Joshua Project, accessed July 31, 2016, http//www.joshuaproject.net/countries.php?rog $3=\mathrm{UV}$. The Joshua Project is an organization dedicated to reaching people groups with the gospel.
} 
Morgan for the SDA Church in East Africa conducted in 2010 indicates the absence of churches, low membership, or minimal SDA presence among nomadic groups. ${ }^{19}$ In spite of attempts to reach the nomads through Global Mission workers, lay groups, and mission agencies, ${ }^{20}$ there has been little, no significant breakthrough, or systematic SDA presence among most pastoralists in the country.

The challenge of proclaiming the gospel among pastoralists can be attributed to multiple factors. First, affinity to culture and resistance to change, often manifested in conservative practices ${ }^{21}$ characteristic of most pastoralist groups, ${ }^{22}$ are possible causes of resistance to the gospel. Although adherence to culture is not a characteristic of pastoralists alone since all peoples have and operate under culture, ${ }^{23}$ efforts to initiate change in the traditional nomadic practices by settling them is the main focus of some agencies. This is done mainly through development projects, introducing them to new

${ }^{19}$ Morgan, "East-Central Africa Division Unreached."

${ }^{20}$ Joel Okindo, East-Central Africa Division, interview by author, Berrien Springs, MI, September 2, 2012. He indicates that there are occasional witnessing activities that employ traditional methods of witnessing particularly public preaching.

${ }^{21}$ Conservatism is defined as opposition to change, desiring to preserve the existing order of things. See Webster's Dictionary and Thesaurus (New Delhi, India: Allied Publishing Group, 2005), s.v. "Conservatism." Cultural conservatism would be the disposition to preserve or restore what is established and to limit change.

22 Paul Tablino, Christianity among Nomads: The Catholic Church in Northern Kenya, 2 vols. (Nairobi, Kenya: Paulines Publications Africa, 2006), 12. See also David J. Phillips, "Peoples on the Move: It Is Past Time to Target the Neglected Nomads," Evangelical Missions Quarterly 35, no. 4 (1999): 410417.

${ }^{23}$ David J. Hesselgrave, Communicating Christ Cross-Culturally, 2nd ed. (Grand Rapids, MI: Zondervan House, 1991), 196. 
religions, or other social reforms, which are perceived by nomads as threats to their core cultural identity. ${ }^{24}$

Second, historically poor responses to the gospel by pastoralists may be a result of unsuitable mission methods. Most missiologists working among nomads suggest that the strategies often used to reach nomads have been based on an inadequate understanding and lack of respect for nomadic cultures. Pointing to this challenge, Malcolm Hunter wonders if the expressions of Christianity the nomads have seen have been so inappropriate that it is our communication that has been far more resistant to the worldview and values of nomadic pastoralist people. ${ }^{25}$ He goes on to argue that mission must be done with attitudes of understanding, consideration, and appreciation of nomadic worldviews because those who have brought the gospel to nomads have often had difficulty leaving behind their own biases or comforts. ${ }^{26}$

David J. Phillips, who observes that because of inapt witness, nomads often consider the gospel to be for farmers or for town-dwellers, echoes Malcolm's sentiments. He insists that methods, media, and message must be empathetic and fully relevant to the nomads' ways of life. ${ }^{27}$

\footnotetext{
${ }^{24}$ Ibrahim O. Ogachi, Transforming Education and Development Policies for Pastoralist Communities in Kenya (Addis Ababa, Ethiopia: Organization of Social Science Research in Eastern and Southern Africa, 2011), 7-13.

${ }^{25}$ Malcolm J. Hunter, “Think Nomadic,” International Journal of Frontier Missions 17, no. 2 (Summer 2000): 9-13.

${ }^{26}$ Ibid.

${ }^{27}$ David J. Phillips, "Peoples on the Move: Toward Christ," International Journal of Frontier Missions 17, no. 2 (Summer 2000): 5-8.
} 
The appeal to be cognizant of nomadic worldviews when doing mission is not isolated to SDA workers alone. Similar calls have been expressed in recent times in various forums such as the Lausanne Conference held in Cape Town, South Africa, in 2010. In the meeting, it was noted that the greatest cause of rejection of the gospel among pastoralists in the past has been the missionaries' misunderstanding of nomadic culture. The "worldview of nomads must be understood by those who would reach them," 28 was the conclusional remark at the conference. Daniel R. Sanchez has also written, "An understanding of the people to be ministered is an absolute necessity for missionaries. Knowledge of cultures holds importance in the effort to communicate the gospel more effectively, for discipling believers, for training leaders, and for establishing indigenous churches." 29

Thus, examining human contexts by assessing what, how, and why people do the things they do is crucial for effective gospel proclamation. As a norm of Christian mission, it is indispensable for mission practitioners to cross cultural boundaries with the gospel, with an aim of transforming people's lives. ${ }^{30}$ A missiological response that would bring such transformation among pastoral nomads has to be considerate of their cultural core beliefs, feelings, values, and experiences. ${ }^{31}$ These tenets that are rooted in culture

\footnotetext{
${ }^{28}$ Aboutalib Fecha, "Best Practices for Reaching Pastoral Nomads," Lausanne Movement, accessed December 23, 2016, http://lausanne.org/uploads/resources/files/11281. See also Hunter, "Think Nomadic," 9-13.

${ }^{29}$ Daniel R. Sanchez, introduction to Worldview: Implications for Missionary Work (Fort Worth, TX: Church Starting Network, 2013), v.

${ }^{30}$ Robert L. Dana, Christian Mission: How Christianity Became a World Religion (West Sussex, UK: John Wiley and Sons, 2011), 8-11.

${ }^{31}$ Hiebert, Transforming Worldviews, 26.
} 
form the basis of worldview and determine the course of action individuals as well as groups are likely to take. Knowledge of the Pokot worldview will potentially unlock their inner cultural mindset and enable mission workers to address issues that are pertinent to their hearts and win them for Christ.

\section{Statement of the Problem}

Despite notable biblical examples of nomads who loved and worshipped God, there are few worshippers of the God of Abraham, Isaac, and Jacob among the Pokot and other Kenyan pastoral nomads. While SDA mission in the country thrives and experiences growth among settled communities, the pastoralists have been relatively unresponsive to Christian influences. Thus the Church is challenged to explore new approaches that would require and include an understanding of nomadic worldviews.

\section{Purpose of the Study}

The purpose of this research is to (1) describe the cultural worldview of the Pokot of Kenya, and (2) propose a biblically faithful and culturally appropriate model for effective mission and ministry among the Pokot and other nomads.

\section{Research Questions}

The main research questions guiding this study are:

1. What are the worldview themes, systems, and values of the Pokot?

2. What are the current and past missiological approaches employed in Kenya among the Pokot and other nomads, and why have they been generally ineffective?

3. Based on the understanding of nomadic worldviews, what biblical and cultural strategies and methods are appropriate for mission among the pastoralists? 


\section{Significance of the Study}

It is anticipated that this study will expedite the planning and implementation of more effective SDA mission work among the Pokot and other Kenyan nomads. By enabling gospel witnesses to better understand the Pokot cultural context, the proposed model of mission will potentially enhance SDA mission work in the region.

\section{Conceptual Framework}

The conceptual framework used to guide this study is based on three main missiological principles. First, Christian mission has to be incarnated. This principle is based on the adaptation of the theory of incarnation as a model for mission that was exemplified in the life and ministry of Jesus Christ (John 1:14, Phil 2:5-8). He "mingled with men as one who desired their good. He showed sympathy for them, ministered to their needs, and won their confidence." ${ }^{32}$ Christ's apostles, particularly Paul, also modeled incarnation as they witnessed across cultures by identifying themselves with local contexts (1 Cor 9:19-23).

In modern times, incarnation as an ideal model for mission is also advanced by many missiologists as defined by three major reasons: (1) the missionary must identify with the environment of the respondent community by incarnating into the culture of the people, learning how they think and make decisions, in order to aid the process of communicating the gospel in ways that can be understood; (2) the message has to be translated into the cultural context of the target group, a principle that embraces the use of

\footnotetext{
${ }^{32}$ Ellen G. White, Ministry of Healing (Boise, ID: Pacific Press, 1942), 143.
} 
communication methods, symbols, and objects that are familiar to the target group; ${ }^{33}$ and (3) incarnation as a motif should serve as the criteria and method for contextualizing the gospel that is "never-changing to the ever-changing cultures of the world." 34

In addition to being rooted in an incarnational focus, this study is also based on the principle that culture has deep structures that must be understood for effective mission work. ${ }^{35}$ As a result, an adaptation of Paul G. Hiebert's and Charles F. Kraft's models of exegeting culture is applied in the study of the Pokot cultural worldview. Their models of studying culture offer insights and methodologies for analyzing worldviews that include functions, characteristics, and categories. Based on their analyses, a study of pastoralists' worldviews will aim at understanding the six universal themes of life: classification, person/group, causality, time, space, and relationships.

Kraft argues that these are areas of life with which every known worldview deals. ${ }^{36}$ Hiebert also points to the three dimensions of worldview-cognitive, evaluative, and affective,- - which form the backdrop of culture. He notes that together these three dimension provide people with a way of looking at the world that makes sense to them,

\footnotetext{
${ }^{33}$ Gailyn Van Rheenan, Missions: Biblical Foundations and Contemporary Strategies (Grand Rapids, MI: Zondervan, 1996), 32.

${ }^{34}$ Quoted from Ross Langmead, The Word Made Flesh: Towards an Incarnational Missiology (Lanham, MD: University Press of America, 2004), 201; Craig Ott, Stephen J. Strauss, and Timothy C. Tennent, Encountering Theology of Mission: Biblical Foundations, Historical Developments, and Contemporary Issues (Grand Rapids, MI: Baker Books, 2010), 98-105.

${ }^{35}$ Hiebert, Transforming Worldviews; see also, Paul Hiebert, The Gospel in Human Contexts: Anthropological Explorations for Contemporary Missions (Grand Rapids, MI: Baker Books, 2009) and Kraft, Anthropology for Christian Witness.

${ }^{36}$ Kraft, Anthropology for Christian Witness, 63-65.
} 
gives them a feeling of being at home, reassures them that they are right, and serves as the deep structure on which they construct their explicit belief and value systems. ${ }^{37}$

The final principle guiding this study is the view that mission methodology must be based on an appreciative attitude toward culture. As such, the incarnation motif as a basis of contextualization that is advanced by Craig Ott, Stephen J. Strauss, and Timothy C. Tennent is consulted. Their model presents a view that contextualization is a missiological approach of communicating the gospel that takes into account the validity, respect, and significance of culture. ${ }^{38}$

\section{Methodology}

A literature review to establish definitions, characteristics, and the role of the concept of worldview was conducted. This provided a preliminary understanding of the theory of worldview and how this concept influences people's decision-making processes. In addition, a study of the biblical nomads was carried out along with a review of the general characteristics of nomads as presented by the social sciences with the aim of identifying specific features related to the Pokot and other Kenyan nomads.

Second, qualitative field research was conducted to better understand the Pokot worldview. Data were collected through purposeful sampling of individuals with an indepth knowledge of the community's belief and value systems. Since in pastoral cultures of Kenya the elders are the depositories of the pooled knowledge of the tribe, focus

\footnotetext{
${ }^{37}$ Hiebert, Transforming Worldviews, 65.

${ }^{38}$ Ott, Strauss, and Tennent, Encountering Theology, 102.
} 
groups, ${ }^{39}$ each composed of five Pokot elders, were conducted in three separate villages. Other activities included participant observation ${ }^{40}$ of amuro, a send-off ceremony that is customarily organized for visitors in the village, casual dialogue with informants and community members, and artifact examination, all of which aided me in understanding the belief systems and experiences that are valuable to the Pokot. Information gathered was written in notebooks and videotaped when necessary.

In order to describe SDA mission activities among Kenya's pastoralists in the past and present, personal interviews with church administrators and dialogues with the first baptized Pokot were also conducted. The interviews involved the Western Kenya Union and Western Kenya Conference evangelism directors, and a long time pastor serving in the nomadic regions. These three are currently working and guiding evangelism in Pokot and other pastoralist centers. Finally, analyses of strategies, methods and approaches employed to witness the Pokot were conducted.

\section{Delimitation}

This research focused exclusively on the Pokot of Kenya. Although nomadic communities are spread throughout the entire East Africa region, the research is delimited to the Pokot cultural worldview and Adventist mission activities among them. As a result, initiatives of other Christian groups were not investigated and recommendations given at the end of the writing are directed to the SDA Church even though mission to nomadic pastoralists is a challenge to most Christian groups.

${ }^{39}$ Edgar J. Elliston, Introduction to Missiological Research Design (Pasadena, CA: William Carey Library, 2011), 144-45.

${ }^{40}$ Ibid., 145-46. 


\section{Limitations}

There were four main limitations to this study. First, obtaining an ideal number of subjects for the research was a limitation. Most Pokot men are usually away from home tending animals or attending to community interests. Second, the nomadic lifestyle of the Pokot made it difficult to engage broader interview sessions due to the fact that the interviewees required breaks to attend to their animals. Third, contacting church leaders was also a challenge. They had busy office schedules, which at times required me to go out of my way to search for them and travel long distance. Lastly, limited availability of literature on the Pokot was also experienced due to some information being outdated or not easily on the Internet.

\section{Chapter Outline}

This study is presented in six chapters. Chapter 1 introduces the topic of study and outlines the problem, purpose, and significance of the research. Details of the conceptual framework that guided the study and an explanation of the field research methodology and procedures are also presented.

Chapter 2 covers a literature review of worldview, nomadism, and a history of Christian mission among the Pokot. As a fundamental cultural tenet that has gained prominence in missions, analysis of worldview, which includes the definition, foundations, functions, and the importance of the concept in Christian mission, is offered. Exploration of nomads in Scripture and in the contemporary world is also included. The chapter ends with highlights of particular mission efforts in Pokot areas.

A discussion of the socio-cultural context of the Pokot people is provided in Chapter 3. The chapter begins by examining the migration and settlement of Kenyan 
peoples which began in the seventeenth century. This era perhaps marks the descent of the Pokot and other East African nomads. In addition to the socio-cultural structures, the chapter explores SDA mission initiatives in Pokot.

Chapter 4 describes the ethnography of the Pokot. It explains the field research design that was used and presents the research findings and analyses. Details of the findings are categorized according to the cognitive, evaluative, and affective dimensions of cultural worldview.

A proposed model of mission among the Pokot and other nomads in light of their cultural worldviews is presented in Chapters 5 and 6 . In this comprehensive model, seven fundamental strategies for cross-cultural mission that should also guide SDA witness among the Pokot are examined. Transformation of worldviews, contextualization, and effective communication are detailed in Chapter 5 while the last four-specialization, incarnational ministries, strategic prayer, and group-oriented evangelism are presented in Chapter 6.

Conclusions, summary, and recommendations are offered in Chapter 7. The chapter provides recommendations for what can, and should be done by the SDA Church in its efforts to reach nomadic populations. 


\section{CHAPTER 2}

\section{A THEORETICAL GROUNDING FOR MISSION: WORLDVIEW, NOMADS, AND SCRIPTURE}

\section{Introduction}

An understanding of the relationship between the concepts of worldview, nomadism, and mission is fundamental to this study. Notably, these anthropological and missiological ideas are now widely studied and applied in various disciplines, and at the same time they are casually used in social discourse without proper historical and theoretical considerations. ${ }^{1}$ The widespread application of these key concepts has resulted in limited understanding of their role in the fields to which they are applied, ${ }^{2}$ and potentially erodes the value these concepts for missiology. Since providing meaningful recommendations for Christian witness among nomads is a priority in this research, it is imperative to explore the usage and relevance of these terms within the context of mission.

\footnotetext{
${ }^{1}$ Timothy C. Tennent, Invitation to World Missions: A Trinitarian Missiology for the Twenty-first Century (Grand Rapids, MI: Kreg Academic and Professional, 2010), 53-54. Tennent argues that apart from the secular and casual usage of the term mission, its reference to everything that is done in the Church has resulted in a slow migration of meaning and application from the original theocentric background to a more anthropocentric usage.

${ }^{2}$ David Beine, “The End of Worldview in Anthropology," SIL International, 2010, accessed October 29, 2016, http://www.sil.org/silewp/2010/silewp2010-004.pdf. His defense of worldview as a fundamental construct in anthropology indicates that even within anthropology, worldview is casually used simply to refer to the way people look at the world instead of its analytical functions.
} 
This chapter is divided into three sections: (1) an exploration of the concept of worldview with an emphasis on its definition, characteristics, functions, and relevance to Christian mission, (2) a biblical and social science analysis of nomadism, and (3) a description of Christian mission to the Pokot and other pastoralists.

\section{Worldview}

The concept of worldview originated and developed alongside other philosophical tenets in the nineteenth century and is generally lauded as a significant theoretical development in modern times. ${ }^{3}$ The importance of this concept as an analytical study tool spans across various disciplines, including theology, psychology, sociology, business, education, and anthropology, rendering worldview as one of the most investigated ideological concepts in modern history. ${ }^{4}$ Through its incorporation into the various fields where it is applied, the concept of worldview encourages the study of life from many perspectives. In anthropology, worldview plays a significant role in analyzing human cultures at deeper levels by describing a group's epistemological, ontological, and theological presuppositions. ${ }^{5}$

\footnotetext{
${ }^{3}$ For a comprehensive and illuminating historical account of worldview, see David K. Naugle, Worldview: The History of a Concept (Grand Rapids, MI: William B. Eerdmans, 2002).

${ }^{4}$ Ibid., xviii.

${ }^{5}$ Paul G. Hiebert, Anthropological Insights for Missionaries (Grand Rapids, MI: Baker Books, 2001), 30. Anthropology defines culture as "the more or less integrated systems of ideas, feelings, and values and their associated pattern of behavior and products shared by a group of people who organize and regulate what they think, feel, and do."
} 
Proclamation of the gospel in view of peoples' cultural worldviews is now considered an indispensable approach to effective cross-cultural evangelism. ${ }^{6}$ Fruitful and effective witness to non-Christians and constructive dialogue with unbelievers require Christians to begin at the foundational worldview level, which is the basis of thought, action, and mental interpretation of the world. ${ }^{7}$

Worldview awareness also fosters an understanding of the deep societal structures, relationships, and communication methods of a group, which are necessary tools for appropriate sharing of the gospel. ${ }^{8}$ This understanding is particularly necessary when witnessing to unreached and marginalized groups, ${ }^{9}$ such as the nomads, who have been pushed to the periphery of contemporary political and economic developmentpeople who live at the fringes of society — who nonetheless are in need of the gospel of Jesus Christ. ${ }^{10}$

${ }^{6}$ James N. Anderson, "The Importance of Worldview-Awareness," Crossway, January 24, 2014; Steve Strauss, "Worldview Awareness," Christian Research Journal 28, no. 3 (2005).

${ }^{7}$ Anderson, “The Importance of Worldview-Awareness,” Part 2 and 3.

${ }^{8}$ Strauss, "Worldview Awareness." He argues that worldviews are held beyond rational reasons. They encompass a larger system of value, acceptance, self-identity, purpose, and a person's place in the world. Thus, commitment to a worldview is tightly integrated with the elements in that system.

${ }^{9}$ Stan May, "Cultures and Worldviews," in Best Missional Practices for the 21st Century: Discovering the Mission of God, ed. Mike Barnett (Downers Grove, IL: InterVarsity, 2012), 380.

${ }^{10}$ Douglas J. Hayward, "Ministry to Non-industrialized Peoples: A Selected Bibliography," International Journal of Frontier Missions 14, no. 4 (October-December 1997): 199. 


\section{Definition of Worldview}

Most literature on worldview indicates the need to define the theory contextually. Extensive usage,${ }^{11}$ casual reference, diversified origins, ${ }^{12}$ elusive definitions, a variety of synonyms, and generalizations are among the reasons that worldview is vaguely understood or improperly applied. ${ }^{13}$ In spite of the relative and describer-dependent definitions that are given, efforts have been made to define the worldview concept.

\section{Dictionary Definition}

The Merriam-Webster Dictionary defines worldview simply as, "the way someone thinks about the world," while the Oxford English Dictionary defines it as "a particular philosophy of life or conception of the world." ${ }^{14}$ The term originated in Germany as, Weltanschauung, a combination of two words-Welt (world) and Anschauung (view) - , which denote "a comprehensive view or personal philosophy of human life and the universe." ${ }^{15}$ Thus, worldview is a way of thinking, a conception about the world, a philosophy of life, or one's view of the world and life in it.

\footnotetext{
${ }^{11}$ Mark E. Koltko-Rivera, "The Psychology of Worldviews," American Psychological Association Review of General Psychology 8, no. 1 (2004): 4.

${ }^{12}$ Ken A. McElhanon, "Worldview," Evangelical Dictionary of World Religions (Grand Rapids, MI: Baker Books, 2000), 1032.Western philosophy, which forms the basis of systematic theology, perceives worldview as a system of defense for fundamental Christian beliefs. Anthropologists view worldview as a system which different peoples and cultures use to categorize, structure, and interpret substance, knowledge, and life.

${ }^{13}$ Glenn Rogers, The Role of Worldview in Missions and Multiethnic Ministry (Dallas, TX: Mission and Ministry Resources, 2002), 14.

${ }^{14}$ Merriam-Webster Dictionary, s.v. "Worldview," accessed October 13, 2014, http://www.merriam-webster.com/dictionary/worldview; Oxford English Dictionary, s.v. "Worldview," accessed October 13, 2014, http://www.oxforddictionaries.com/us/definition/.

${ }^{15}$ Collins Dictionary, s.v. "Worldview," accessed October 13, 2014, http://www.collinsdictionary .com/dictionary/english/weltanschauung\#weltanschauung_1.
} 


\section{Social Sciences Definition}

The definition and conceptualization of worldview in the many disciplines where it is applied varies widely. Psychologists describe the notion as "a set of assumptions about physical and social reality that may have powerful effects on cognition and behavior." 16 Worldview describes the universe and life within it in terms of what exists, people's beliefs along with their limiting statements and assumptions, good and bad objects, and experiences among other usages. ${ }^{17}$ In psychology, the concept also addresses knowledge acquisition by describing what can be known and how it can be known, and includes a definition of life goals and how they should be pursued. ${ }^{18}$

\section{Christian theorists such as James W. Sire define worldview as}

A commitment, a fundamental orientation of the heart that can be expressed as a story or in a set of presuppositions, which may be true or entirely false, held consciously or unconsciously, consistently or inconsistently, about the basic constitution of reality and which provides the foundation upon which people live and move and have their being. ${ }^{19}$

James H. Olthuis also compares worldview to a vision of life, a framework, or a set of fundamental beliefs through which people view the world and their calling and their future in it. Olthuis concurs with other theorists noting that worldview may not be articulated, internalized, questioned, explicitly developed into a systematic conception of

\footnotetext{
${ }^{16}$ Mark Koltko-Rivera, abstract to "The Psychology of Worldviews."

${ }^{17}$ Mark E. Koltko-Rivera, “The Worldview Assessment Instrument (WAI): The Development and Preliminary Validation of an Instrument to Assess Worldview Components Relevant to Counseling and Psychotherapy," abstract (PhD diss., New York University, 2000).

${ }^{18}$ Ibid.

${ }^{19}$ James W. Sire, Naming the Elephant: Worldview as a Concept (Downers Grove, IL: InterVarsity, 2004), 122.
} 
life, theoretically deepened into a philosophy, or codified into a creedal form, yet it is a channel for ultimate beliefs, which give direction, and meaning to life. ${ }^{20}$

Others, such as William T. Wright, describe the worldview concept as the grid through which humans perceive reality, a framework embedded in stories, symbols, praxis, basic questions, and answers. ${ }^{21} \mathrm{~J}$. de Waal Dryden, who agrees that worldview is embodied in particular cultural ethos and artifacts like pottery, architecture, literature, clothing, philosophy, and sports, describes the concept as "an all-encompassing picture of reality touching all spheres of human knowledge and activity that serves to integrate human existence into a comprehensible unity."22 Even though anthropologists debate whether worldview is still a valuable analytical construct, ${ }^{23}$ the concept nonetheless remains useful in Christian mission.

Christian anthropologists regard worldview as a subset of culture and define it under that assumption. Charles H. Kraft describes the concept as "culturally structured

\footnotetext{
${ }^{20}$ James H. Olthuis, “On Worldviews,” in Stained Glass: Worldviews and Social Sciences, ed. Paul A. Marshall et al. (Lanham, MD: University Press, 1989), 26-40.

${ }^{21}$ Nicholas T. Wright, The New Testament and the People of God (Minneapolis, MN: Fortress, 1992), 1: 38 .

22 J. de Waal Dryden, Theology and Ethics in 1 Peter: Paraenetic Strategies for Christian Character Formation (Tubingen, Germany: Mohr Siebeck, 2006), 55.

${ }^{23}$ Beine, "The End of Worldview." In his ten-year study of the usage of the worldview concept in the field of anthropology, Beine discovered that although some anthropologists no longer consider worldview a valuable analytic construct, the concept remains in strong usage within contemporary anthropology. However, this interest was noted within particular anthropological specialties such as cognitive anthropology, medical anthropology, psychological anthropology and linguistic anthropology, which typically characterize the newly emerging paradigm of the anthropological sciences.
} 
assumptions, values and commitments underlying people's perception of Reality." ${ }^{24}$ His contemporary Paul G. Hiebert notes that the concept is composed of three main dimensions - cognitive, affective, and evaluative. With this presupposition, he defines worldview as "the foundational cognitive, affective, and evaluative assumptions and frameworks a group of people makes about the nature of reality, a fundamental cultural structure through which life is ordered." 25

Thus, the various ways in which worldview is defined and ultimately conceptualized imply that people view and understand the world, reality, and other aspects of human existence in diverse ways. It also means people respond and structure life differently based on their worldviews. In this study, worldview is defined within the frameworks heretofore given - a cultural structure shared by a people which they use to define their world and their reality, in order to provide meaning and purpose for life within a variety of circumstances.

\section{Worldview Functions}

As a lens through which people view the world and ultimately structure life, the worldview concept is a significant cultural construct within any group, serving various

\footnotetext{
${ }^{24}$ Charles H. Kraft, Christianity with Power: Your Worldview and Your Experience of the Supernatural (Ann Arbor, MI: Servant, 1989), 20. Kraft uses reality with a small $r$ to describe how human beings understand things (subjective reality) and Reality with capital $R$ to describe how God sees things (objective reality). See Ibid., 11-22.

${ }^{25}$ Hiebert, Transforming Worldviews, 25-26.
} 
social as well as cultural functions. These functions include: the provision of answers, the offering of emotional stability, authentication, integration, monitoring, and assurance. ${ }^{26}$

Worldview first provides answers to people's questions about ultimate reality, such as the origin of the earth, humanity, divinity, sin, tragedy, remedy, and destiny. ${ }^{27} \mathrm{By}$ offering mental models or blueprints of deeply ingrained assumptions, ${ }^{28}$ worldview attempts to explain where humans came from, the purpose of their existence, and their final destiny. Theories such as creationism and explanations of heaven and hell are forms of worldview. For a Christian, these theories answer questions regarding origins. ${ }^{29}$

Second, worldview offers emotional stability in stressful and uncertain life moments. It is notable that during life-changing events such as births, initiations, marriages, funerals, harvests, and celebrations, worldviews are most evident. ${ }^{30}$ On these occasions, when people are often challenged deeply and emotionally, worldview offers "psychological reinforcements," that are rooted in their cultural assumptions, enabling

\footnotetext{
${ }^{26}$ Ibid., 28-30. Charles Kraft expands these six functions to ten. See Kraft, Anthropology for Christian Witness, 58-63.

${ }^{27}$ James W. Sire, The Universe Next Door, 5th ed. (Downers Grove, IL: InterVarsity Press, 2009),
} 22. These questions are the focus of formal religions, which seek to find ontological meaning in life. These questions wrestle with the origins, purpose, and destiny of the universe, people, and individuals - the cosmic realities. For more discussion, see Paul G. Hiebert, R. Daniel Shaw, and Tite Tienou, Understanding Folk Religion: A Christian Response to Popular Beliefs and Practices (Grand Rapids, MI: Baker Books, 1999), 249-250; Eddie Karl Baumann, Worldview as Worship: The Dynamics of a Transformative Christian Education (Eugene, OR: Wipf and Stock, 2011), 19-23.

${ }^{28}$ Hiebert, Transforming Worldviews, 29.

${ }^{29}$ Debates regarding origins have always existed between science and religion, with the latter supporting the creation account. See, for example, John H Walton, The Lost World of Genesis One: Ancient Cosmology and the Origins Debate (Downers Grove, IL: InterVarsity, 2009).

${ }^{30}$ Ibid. 
people to mentally relax in the face of uncertainty ${ }^{31}$ Most cultures prescribe certain cerebrations, rituals, and other interventional mechanisms to assist members during such transitions.

Additionally, each society offers guidelines, whether scripted or memorized, which promote and encourage appropriate behavior among its members. Similarly, taboos are instituted to discourage and deter inappropriate behavior. ${ }^{32}$ This regulatory function is enabled by worldview through its predictive and prescriptive roles, which validate deep cultural norms used to evaluate people's experiences and choices. ${ }^{33}$ Moral standards, punishment, and ideals are embedded in a worldview.

Fourth, worldview unifies. By integrating the ideas, feelings, and values of a society, worldview enables people to live harmoniously as a group with a more or less cohesive unified view of reality. ${ }^{34}$ This function explains why individual decisions in communal cultures are not taken seriously since members of a society exist as a unit. ${ }^{35}$ Unification can also be seen in aspects of each culture's unique ways of doing things and the collective actions that are beyond an outsider's comprehension. ${ }^{36}$

${ }^{31}$ Charles H. Kraft, Culture, Communication, and Christianity: A Selection of Writings (Pasadena, CA: William Carey Library, 2001), 109.

${ }^{32}$ Kraft, Anthropology for Christian Witness, 62, 343-357.

${ }^{33}$ Hiebert, Transforming Worldviews, 29.

${ }^{34}$ Hiebert, Transforming Worldviews, 29.

${ }^{35}$ George A. Phiri, Social-Cultural Anthropology: Christian Communication with the African Society (Eugene, OR: Resource, 2009), 24. 60.

${ }^{36}$ Larry Samovar et al., Communication between Cultures, 8th ed. (Boston, MA: Cengage, 2013), 
A fifth aspect of worldview is its role in monitoring cultural change. ${ }^{37}$ Outside influences or changes that arise within a culture may cause instability or disrupt unity. Any pressure from new ideas, behavior, or products that has the potential to break the cultural fabric of a people is often rejected. This includes assumptions that undermine the society's cognitive order, unless they fit the overall cultural pattern. ${ }^{38}$

Finally, worldview provides psychological assurance that the world is truly as it is and supplies a sense of peace and being at home. In Terror Management Theory, a concept that was developed to explain humanity's capabilities to develop positive responses to danger, ${ }^{39}$ it was concluded that worldview is an instrument that provides assurance - the conviction that the world is not simply chaotic and dangerous, but is also orderly and its dangers are manageable if people live appropriately. ${ }^{40}$

\section{Worldview and Christian Mission}

The significance of the worldview concept in Christian mission is built on the inherent collaboration between Christian anthropology and Christian mission. This recent development, which was a response to the ethnocentrisms of stereotyping, racism, ignorance, and generalizations that engulfed Christian mission in the past, ${ }^{41}$ has aided

${ }^{37}$ Charles H. Kraft, Christianity in Culture: A Study in Dynamic Biblical Theologizing in Cross Cultural Perspective (Maryknoll, NY: Orbis Books, 1979), 56.

${ }^{38}$ Hiebert, Transforming Worldviews, 29.

${ }^{39}$ Eugene Webb, Worldview and Mind: Religious Thought and Psychological Development (Columbia, MO: University of Missouri, 2009), 71-72.

${ }^{40}$ Webb, Worldview and Mind, 71-72.

${ }^{41}$ Van Rheenen, Missions, 97-111. 
cross-cultural evangelism in many regions. Insights from anthropological research have spearheaded missionary work to other people. Human contexts, which are the field for gospel proclamation, are understood better at their deeper cultural levels. ${ }^{42}$

Through the work of anthropologists such as Ruth Benedict (1887-1948), ${ }^{43}$ Robert Redfield (1897-1958), ${ }^{44}$ Edward Sapir and Benjamin Whorf, Mary Douglas (1921-2007), ${ }^{45}$ Michael Kearney (1937-2009), ${ }^{46}$ and recently Charles Kraft ${ }^{47}$ and Paul Hiebert, ${ }^{48}$ cultures' deep structures have become more unveiled. These researchers' findings reveal the subconscious levels of culture-worldview, far below the surface levels that are visible to the human eye. This has become a fundamental focus for Christian witnessing and conversion.

Ralph Winter's speech at the Lausanne Congress on World Evangelization in 1974 inaugurated "a dramatic shift in missiological thinking"49 that focused on studying people at their basic cultural levels. It is noted that prior to the congress, interpretation of the Great Commission (Matt 28:18-20) was mostly centered on locations rather than

${ }^{42}$ Hiebert, The Gospel in Human Contexts, 76.

${ }^{43}$ Ruth Benedict, Patterns of Culture (New York: Mariner Books, 2005).

${ }^{44}$ Clifford Wilcox, Robert Redfield and the Development of American Anthropology (Lanham, MD: Lexington Books, 2004), 146.

${ }^{45}$ Mary Douglas, Natural Symbols: Explorations in Cosmology (New York: Taylor and Francis, 2004), 57-71.

${ }^{46}$ Michael Kearney, World View (Novato, CA: Chandler \& Sharp, 1984), 14.

${ }^{47}$ Charles H. Kraft, Worldview for Christian Witness (Maryknoll, NY: Orbis Books), 12; Kraft, Anthropology for Christian Witness, 63-64.

${ }^{48}$ Hiebert, Transforming Worldviews, 28-30.

49 Tennent, Invitation to World Missions, 359-370. 
focusing on evangelism to ethnic people groups around the world. These groups which later came to be known as "unreached people groups," drew missionaries' attention, and concerned agencies began drawing up lists, publishing ethnographic research, and mapping projects.

The new approach of evangelism that focused on people at their cultural levels was intended to ensure that the gospel was communicated to different world cultures in ways that could be understood by the hearers. ${ }^{50}$ Although Winter's proposition retained a geographical focus which he called the 10/40 Window, spanning across North Africa and Asia, ${ }^{51}$ missiologists have nonetheless continued to propagate the gospel in light of people's cultural orientations for the following reasons.

\section{For Authentic Transformation}

First, worldview describes people's understanding of reality. For Christian witnesses to better address the needs of the target people so as to complete the cycle of mission, it is imperative to understand their experiences, assumptions, and logic. This approach is necessary for making Christian witness relevant and also supports effective and genuine transformation while counteracting surface-level change that often results in christo-paganism and syncretic practices. ${ }^{52}$

Christian ministry should seek transformation of the whole culture, not just the modification of external behavior alone. Scripture confirms that the starting point for

\footnotetext{
50 Stan May, "Cultures and Worldviews,” 378.

${ }^{51}$ Greg H. Parsons, Lausanne' 74: Ralph D. Winter's Writings with Responses (Pasadena, CA: William Carey Library, 2015), 1-10.

${ }^{52}$ Hiebert, Transforming Worldviews, 69.
} 
such change is internal rather than external (Matt 23:24-27; Luke 11:38-42)." ${ }^{\text {53 }}$ This means true lasting change requires transformation that begins at the worldview level. ${ }^{54}$ This type of transformation is integral to biblical conversion. ${ }^{55}$ Heart matters are to be diligently addressed because it is in the heart that serious decisions are made (Deut 4:9; Prov 4:23, Matt 12:34, 15:18-19).

Since the primary task of Christian mission is the proclamation of God's salvation for the conversion of unbelievers, ${ }^{56}$ total transformation that includes a change of both the visible lifestyle traits and the invisible worldview assumptions should be emphasized.

\section{For Effective Communication}

Meaning is created by hearers rather than the speaker. ${ }^{57}$ Understanding the communication patterns of a people is an imperative in missions. ${ }^{58}$ Missionaries should

\footnotetext{
${ }^{53}$ Robert Strauss and Tom Steffen, "Change the Worldview, Change the World," Evangelical Missions Quarterly, 45 no. 4 (October, 2009): 463. Both authors assert that a ministry that focuses on observable phenomena is insufficient and fundamentally disrespectful, adding that ministry is never complete until true and lasting change is achieved by addressing core worldview assumptions and values.

${ }^{54}$ Gailyn Van Rheenen, Communicating Christ in Animistic Contexts (Pasadena, CA: William Carey Library, 1991), 90. He states that a Christian conversion without worldview change in reality is syncretism.

${ }^{55}$ Larry L. Lichtenwalter, "Worldview Transformation and Mission: Narrative, Theology, and Ritual in John's Apocalypse," Journal of the Adventist Theological Society 21, nos. 1-2 (2010): 211. He challenges SDA mission to seek personal and corporate transformation, leading people to experience biblical conversion, which should include belief, being, behavior, worship, and underlying cultural presuppositions.

${ }^{56}$ Ott, Strauss, and Tennent, Encountering Theology of Missions, 106-113.

${ }^{57}$ Charles H. Kraft, Communication Theory for Christian Witness (Maryknoll, NY: Orbis Books, 1991), 81-98.

58 The Willowbank Report: Lausanne Theology and Educational Group, "Changing Cultures and the Gospel," Third Way: Towards a Biblical Worldview 2, no. 11 (June 1978): 3. Following the First International Congress on World Evangelization, the cultural factor in evangelism is emphasized with an admonition that no Christian witness can succeed at communicating the gospel meaningfully if the cultural factor is ignored since missionaries are products of one culture and are inevitably involved in cross-cultural
} 
undertake this task during the initial stages of developing a people group profile. An

understanding of how people communicate with one another, how they pass on their cultural heritage to younger generations, how education is presented, and how they prefer to learn should be sought. ${ }^{59}$ This knowledge challenges missionaries to choose appropriate and relevant communicative strategies that will enable the audience to hear and make informed responses.

\section{For Contextualization}

The worldview concept is a viable tool in mission operandi as an operational tool to affect contextualization. By using oral communication strategies such as storying, songs, proverbs, and narrative, the gospel is presented in culturally appropriate and palatable means, which is a recipe for positive responses. ${ }^{60}$ Additionally, worldview unveils important cultural beliefs, rituals, stories, or artifacts that may form bridges for

communication. It is noted that sometimes people resist the gospel not because they think it is false but because they perceive it as a threat to their culture, especially the fabric of their society and their national or tribal solidarity. Additionally, the gospel is often presented to people in alien cultural forms leading to resentment of the missionaries as their message is rejected. Their work is seen not as an attempt to evangelize but as an attempt to impose their own customs and ways of life. It is also observed that when missionaries bring with them foreign ways of thinking and behaving, or attitudes of racial superiority, paternalism, or preoccupation with material things, effective communication is often hampered.

59 J. D. Payne and John M. Terry, Developing a Strategy for Missions (Encountering Mission): A Biblical, Historical, and Cultural Introduction (Grand Rapids, MI: Baker Books, 2013).

${ }^{60}$ Oral communication strategies such as story, proverb, poetry, drama, and song, have been the focus of study and application in many fields, given that a large number of the world's population are oral communicators who think in terms of stories, and not in outlines, guidelines, principles, steps, concepts, or propositions, which are largely foreign to their way of learning and communicating. See, for example, Steven Evans, "Communicating Christ in a Cross-Cultural Context: Developing Effective Media and Communication Strategies Leading to Church Planting Movements," accessed November 23, 2016, www.reachingandteaching.org/wp-content/uploads/sites/8/2014/06/WorldofOrality.pdf. 
the gospel. ${ }^{61}$ Analogies such as the Peace Child story, told by Don Richardson, ${ }^{62}$ indicate that in each culture, there can be found meaningful structures that can be used to unravel the mysteries of the gospel.

\section{To Create Respect for Culture}

As previously discussed, people view the world and interpret reality differently. Missionaries who are the products of one cultural orientation but are engaged in crosscultural evangelism need to be aware of this truth. In the past, ethnocentric errors occurred in the mission field partly because of missionaries judging other cultures from within their own cultural contexts. ${ }^{63}$ Through research and reflection on mission practice, evangelism in light of cultural differences is likely to lead to greater respect toward others and the avoidance of the errors of the past.

\section{Nomadic Cultures}

To provide a clearer picture of the worldview of nomadic cultures, this section explores various groups of people whose lifestyle is nomadic. It is expedient to clarify here that the lifestyle of moving, nomadism, is not a culture in its entirety. Peterson observes that nomads are compelled to move because of the needs of their animals. ${ }^{64}$

\footnotetext{
${ }^{61}$ Scott A. Moreau, Contextualization in World Missions: Mapping and Assessing Evangelical Models (Grand Rapids, MI: Kregel, 2012), 146.

${ }^{62}$ Don Richardson, Peace Child: An Unforgettable Story of Primitive Jungle Treachery in the 20th Century (Ventura, CA: Regal Books, 2005).

${ }^{63}$ Stephen B. Bevans, Models of Contextual Theology (Maryknoll, NY: Orbis Books, 2002), 250.

${ }^{64}$ Gideon Petersen, "Ministry to Nomads: A Comprehensive Missiological Approach" (PhD diss., University of the Free State, 2011), 88.
} 
Thus nomadism describes more an economic activity or lifestyle of people who nonetheless retain distinctive cultural beliefs and customs that define them. This study focuses on the cultural beliefs and practices of the Pokot people.

\section{Definition of Nomads}

The origin of the English word nomad can be traced to the Greek word nomas, which means "wandering" or "roaming in search of pasture." ${ }^{65}$ Although debate over a precise definition of nomadism is on-going ${ }^{66}$ because some nomads have permanent settlements, the noun nomadism generally describes the transitory lifestyle of a community in movement. This way of life does not suggest unrestricted or undirected wandering but rather periods of temporary stability depending on the availability of resources such as food supplies, pastures, water, and the technology for exploiting them. $^{67}$

According to the Webster-Merriam Dictionary, nomadic people are mostly without a permanent abode, moving from place to place instead of settling in one area permanently. ${ }^{68}$ Although there exist other transitory populations such as migrants and refugees, these groups differ widely from nomads. Most people move from one place of

\footnotetext{
${ }^{65}$ The Free Dictionary, s.v. "Nomad,” accessed July 3, 2016, http://www.thefreedictionary.com /nomad.

${ }^{66}$ Giorgio Ausenda, ed., After Empire: Towards an Ethnology of Europe's Barbarians (San Francesco, CA: Boydell, 2002), 26.

${ }^{67}$ Encyclopedia Britannica, s.v. "Nomadism," accessed November 4, 2016, http://www .britannica.com/EBchecked/topic/417292/nomadism.

${ }^{68}$ Merriam-Webster Dictionary, s.v. "Nomad,” accessed July 13, 2016, http://www.merriamwebster.com/dictionary/nomad.
} 
residence to another permanent settlement, ${ }^{69}$ while nomads move periodically or cyclically, reaching destinations without the purpose of settling. Fixed locations are utilized as resupply and refresher points or as temporary harbors during extreme weather." ${ }^{, 70}$ Their trek is continuous and often leads back to the original location, from which their journey began. ${ }^{71}$ Thus, regular periodic movement is the chief characteristic of the nomadic people.

\section{Types of Nomads}

There are three main categories of nomads differentiated by their chief means of subsistence: hunter-gatherers, peripatetics, and pastoralists. ${ }^{72}$ Hunter-gatherers survive mainly through hunting wild animals and gathering or cultivating seasonal edible crops. Their movement is necessitated by changes in seasons and limited quantities of food and raw materials. By constantly moving, cultivation of new areas and natural replenishment of depleted resources takes place. ${ }^{73}$ In addition to the hunter-gatherers are those referred to as "sea nomads." Sea nomads do not have a pure hunter-gathering lifestyle because they also rely on other sources for sustenance. They are nonetheless predominantly

${ }^{69}$ Richard Grant, American Nomads: Travels with Lost Conquistadors, Mountain Men, Cowboys, Hoboes, Truckers, and Bull-riders (New York: Grove, 2003), 142.

${ }^{70}$ Ibid., 142.

${ }^{71}$ New World Encyclopedia, s.v. "Nomad," s.v. "Nomad," accessed December 18, 2016, http://www.newworldencyclopedia.org/entry/Nomad

${ }^{72}$ Phillips, Peoples on the Move, 8.

${ }^{73}$ Ibid. 
foragers. Their mobility represents a significant economic, social, and cultural part of life. ${ }^{74}$

Peripatetics are also known as service nomads, commercial nomads, non-foodproducing nomads, symbiotic nomads, wanderers, and travelers. ${ }^{75}$ These groups move among settled communities to offer services or crafts thereby earning their income. While peripatetic nomadism seems to be diminishing globally, some communities in Asia, the Middle-East, Africa, and Europe still practice semi-peripatetic nomadism.

Nomadic pastoralists are the largest, most common, and most frequently referenced nomadic type. The chief characteristic of pastoralists is dependence on animal husbandry in arid and semi-arid lands which requires them to continually on the move to find adequate grazing land and water. ${ }^{76}$ Although pastoralism is a broad term and may include other economic forms like transhumance, agro-pastoralism, and nomadic pastoralism, ${ }^{77}$ herding animals and moving in search of pasture defines their socioeconomic life. $^{78}$

${ }^{74}$ Jérémie Gilbert, Nomadic Peoples and Human Rights (New York, NY: Routledge, 2014), 7.

${ }^{75}$ Ibid., 7.

76 "Defining Nomadic Pastoralists," Nomadic Peoples Network, accessed November 18, 2016, http://nomadicpeoples.net/defining-nomadic-pastoralists/.

${ }^{77}$ Sarah M. Nelson, Identity and Subsistence: Gender Strategies for Archaeology (Lanham, MD: AltaMira, 2007), 238-39.

${ }^{78}$ Phillips, Peoples on the Move, 7. 


\section{Population and Geographical Locations}

Establishing the demographics of a nomadic population is a challenge to most researchers and governments. Constant movement, marginalization, hostile environments without access to modern technology, and general negative attitudes held toward nomads are among the reasons why their populations are poorly understood. ${ }^{79}$ Even though the notion that pastoralism is declining exists among most scholars, ${ }^{80}$ research shows that nomadism is still vibrant in many regions and that nomads still constitute a significant portion of the population in some parts of the world. ${ }^{81}$

The New Internationalist Magazine, which exists to report on issues of world poverty and inequality, estimates that there were about thirty to forty million pastoral nomads spread throughout the six continents of the world in $1995 .^{82}$ By 2011 , Malcolm Hunter reported the nomadic population had increased to about 200 million people, nearly equal to the number of people on earth when Jesus gave the Great Commission

\footnotetext{
${ }^{79}$ Nomads are categorized among the "hard-to-reach populations." Tom W. Smith, "Surveying Hard-to-Reach Populations in Comparative Perspective," University of Chicago GSS Cross-National Report No. 33, November 2012, accessed July 31, 2016, publicdata.norc.org:41000/gss/documents/CNRT /CNR\%2033.pdf; see also World Health Organization, "Eritrea: Map of the Migratory Routes of the Nomads in Northern and Southern Red Sea Zobas, May 30, 2007, accessed November 27, 2016, $\mathrm{http} / / /$ reliefweb.int/report/eritrea/eritrea-map-migratory-routes-nomads-northern-and-southern-red-seazobas.

${ }^{80}$ Pastoralism in most of sub-Saharan Africa is said to be declining due to (1) modern technology and improved animal husbandry methods and (2) government border restrictions on the pastoralists for ecological reasons. Pastoralists are viewed as the motor for desertification and environmental destruction. See Neville G. Gregory and Temple Grandin, Animal Welfare and Meat Production (Cambridge, MA: CAB International, 2007), 15; Pierre Hiernaux, The Crisis of Sahelian Pastoralism: Ecological or Economic? (Addis Ababa, Ethiopia: International Livestock Centre for Africa, 1996), 3.

${ }^{81}$ Phillips, Peoples on the Move, xv.

82،"The Facts," New Internationalist, April 5, 1995, accessed November 18, 2016, http://newint.org/features/1995/04/05/facts/; Encyclopedia Britannica, s.v. "Nomadism," accessed November 4, 2016, http://www.britannica.com/EBchecked/topic/417292/nomadism.
} 
(Matt 28:18-20) ${ }^{83}$ Although no current data of nomads' demographics are available, their growth trends since 1995 suggest their numbers have increased.

\section{Examples of Nomads}

Pastoral nomads are spread throughout the world. Heavy populations of nomads can be found in countries such as Pakistan, India, Iran, Afghanistan, Kenya, Tanzania, Namibia, and Nigeria. It is estimated that there are 9.3 million nomads in Nigeria. ${ }^{84}$ Notably large communities include the Fulani of West Africa, the Amazigh (Berbers) of North Africa, the Tuareg of the Sahara Desert, the Masaai of East Africa, the Qashqai of Iran, the Roma of Eastern Europe, the Bedouin of the Middle East and North Africa, the Kuchi of Afghanistan, the Sami of Scandinavian countries and the Tibetan nomads of China, India, Nepal, and Bhutan, among others. ${ }^{85}$ Apart from these, there are also smaller groups who live along the borders of many countries.

\footnotetext{
${ }^{83}$ Malcolm Hunter, "Who Are These Nomadic People and Why Bother about Them?" Nomadic Peoples Network, August, 2011, accessed November 1, 2016, http://nomadicpeoples.net.

${ }^{84}$ Fatimah Kelleher, "Reaching Nomadic Communities: Providing Inclusive Quality Education," Commonwealth Education Partnership 2007, accessed October 21, 2016, www.cedol.org/wp-content /uploads/2012/02/65-67-2007.pdf.

${ }^{85}$ Dave Dalton, People on the Move: Nomads and Travelers (Chicago: Heinemann, 2006), 45-46; Lorraine Boissoneault, "The World's Last Wanderers: 10 Nomadic Peoples," The Weather Channel, September 3, 2013, accessed on November 27, 2016, http://www.weather.com/travel/news/worlds-lastwanderers-10-nomadic-peoples-20130828\#/5. For a more comprehensive survey of world nomads, see Phillips, Peoples on the Move, 137-449.
} 


\section{Nomads of Kenya}

Of the forty-five tribes that compose Kenya's population, ten communities are pastoral nomads classified linguistically as Nilotes or Cushites. ${ }^{86}$ These groups, which migrated mostly from southern Sudan, the Ethiopian highlands, and Somalia during the sixteenth- and seventeenth-century migration of East African peoples, ${ }^{87}$ include the Maasai, Turkana, Somali, Pokot, Samburu, Rendile, Gabbra, Orma, Boran, and Daasanach peoples. ${ }^{88}$ According to Lewis M. Paul, there are more than 2.5 million members in these communities. ${ }^{89}$ While the accuracy of these figures is often disputed due to frequent movement which prohibits systematic censuses, these numbers are still significant.

Kenya's pastoralists occupy up to seventy-five percent of Kenya's total landmass. They spread out over the dry northeast, northwest, southern rift, and the inland parts of the coast. ${ }^{90}$ They can also be found along the border areas with Somalia, Ethiopia, Sudan, Uganda, and Tanzania.

\footnotetext{
${ }^{86}$ Paul Spencer, Nomads in Alliance: Symbiosis and Growth among the Rendile and Samburu of Kenya (New York: Oxford University Press, 1973), 1.

87 “Conflict Assessment: Northern Kenya,” Pragya, accessed May 10, 2016, http://www.pragya .org/doc/Conflict_Assessment_Report.pdf.

${ }^{88}$ For a detailed sketch of the migration and settlement of Kenyan tribes, see Kizito Muchanga, History and Government (Nairobi, Kenya: East Africa Educational Publishers, 2006), 22-31.

${ }^{89}$ Lewis M. Paul, Ethnologue: Languages of the World, 16th ed. (Dallas, TX: SIL International, 2009).

${ }^{90}$ Abdi Umar, "Resource Utilization, Conflict, and Insecurity in Pastoral Areas of Kenya," (paper presented at the USAID Seminar on Conflict Resolution in the Horn of Africa, Nairobi, Kenya, March 27 29, 1997), 2.
} 


\section{Christian Mission among East African Nomads}

Christian witness among nomadic people has always been a challenge. The nomads' lifestyle of frequent movement in search of pasture for their animals, negative attitudes toward outside influences like Christianity (which is viewed as a religion for women and children), ${ }^{91}$ and their life on the fringes of society are some of the main reasons attributed to the ineffective witness of the gospel among them. In spite of these challenges, efforts to reach the nomads of Kenya and those of the East African region continue to be a priority for many mission agencies.

One notable mission group in the area is the Comboni Missionaries, founded in 1867 by St. Daniel Comboni. Their area of concentration is mostly in South Sudan among pastoral communities such as the Dinka, Nuer, Bari, Mundari, and Kuku. ${ }^{92}$

Through collaboration with local Catholic churches, the Comboni Missionaries conduct various witnessing activities. They are engaged in evangelization and pastoral care among the nomads, fostering the formation of leaders, lay ministers, priests and missionaries. They are also involved in mission animation, vocational promotion, education, and health care, while at the same time advocating for justice, peace, and

\footnotetext{
${ }^{91}$ This view is prevalent particularly among older men of most pastoralist societies like the Pokot because early Christian mission came through schools where children were the main target of the missionaries. See Cliff Barton, "Missionary Spotlight—Kenya, Reaching the Pokot People," Evangelical Times: Christian News and Comments, November 2007, accessed December 23, 2016, http://www .evangelical-times.org/archive/item/2657/Kenya/Missionary-Spotlight---Kenya-reaching-the-Pokotpeople/; Afe Adogame, Janice McLean, and Anderson Jeremiah, eds., Engaging the World: Christian Communities in Contemporary Global Societies (Eugene, OR: Wipf and Stock, 2014), 29.

${ }^{92}$ For more information of their activities, see Comboni Missionaries: South Sudan, accessed December 22, 2015, http://www.combonisouthsudan.org/.
} 
reconciliation among warring nomadic factions. ${ }^{93}$ They utilize mass media through their participation in the Catholic Radio Network.

Coordination of efforts to reach nomads is observable in other places. Notable is northern Kenya where the Catholic Church, African Inland Church, and the government have cooperated to develop agricultural settlements during periods of drought since the early 1970s. ${ }^{94}$

\section{Nomads in Scripture}

Historically, it should be noted that a considerable portion of the biblical narrative describes the socioeconomic life and activities of people who were nomadic. Several Old Testament books and chapters ${ }^{95}$ are entirely devoted to stories of figures such as Abraham, Lot, Isaac, Jacob, the Israelites, and others who moved from place to place with their livestock searching for pasture and sources of water. ${ }^{96}$ Their stories reveal a

${ }^{93}$ Ibid.

${ }^{94}$ Elliot Fratkin and Eric Abella Roth, As Pastoralists Settle: Social, Health, and Economic Consequences of the Pastoral Sedentarization in Marsabit District, Kenya (New York: Plenum, 2006), 44.

${ }^{95}$ The books of the Pentateuch are particularly devoted to stories of nomadic patriarchs and the nation of Israel. Other books such as Joshua also present the conquest of Canaan by migrating Israelites and their eventual settlement in Canaan.

${ }^{96}$ Igor P. Lipovsky, “At the Sources of Biblical History,” accessed on September 22, 2016, http://www.biblicaltheology.com/Research/LipovskyIP02.pdf. Lipovsky observed that the Old Testament patriarchs were heads of a network of families or clans that grazed together and carried out other economic activities as a group until their population enlarged enough to separate. He argues that the separations, which occurred between Abraham and Lot, Isaac and Ishmael, and finally Jacob and Esau, were triggered by population growth, which had gradually become sufficient to lead to their ability to function as separate and independent peoples. The keeping of animals, which was the principal occupation of these tribes, did not allow a large group of fellow tribesmen to come together on any one segment of territory. This forced them to constantly search for new land with adequate pasture and sources of water for their cattle. Abraham's departure to the south of Palestine was not a result of the high density of population in the central part of the country but of the lack of available pasture. There, in southern Canaan, Jacob and Esau, his descendants through Isaac, found a new homeland for themselves and their tribes. 
developing and enduring relationship between God and those who wander in deserts and remote areas of the earth looking after animals.

\section{A Nomadic God}

God's love for and interest in nomads is founded on God's very nature of being transcendent, unbound by time or space ${ }^{97}$ Throughout the journeys of the Israelites, God walked with and among them, promising to be with them wherever they were sent (Exod 33:14). On their journey from Egypt to Canaan, the Lord's guidance was signified by a pillar of cloud by day and a light by night (Exod 13:21-22).

\section{Calling Nomads unto Salvation}

Abraham was called to move from his home country of Ur, where he lived with his father Terah and his extended family, to a land that God would show him (Gen 12:13). These texts demonstrate that the future custodian of God's plan of salvation had grown up in the midst of a culture that was predominantly idolatrous, superstitious, and heathen. ${ }^{98}$ In order for God to qualify him for service, Abraham had to separate from the associations of his early life. ${ }^{99}$ During the encounter with Abraham, God pronounced three promises: to make of him a great nation, to provide him with a blessing, and to make his name great (Gen 12:2).

\footnotetext{
${ }^{97}$ Phillips, Peoples on the Move, 55.
}

98 Joseph S. Exell, "Commentary on Genesis 12:1-3," The Biblical Illustrator (BI) (Grand Rapids, MI: Baker Books, 1954), 1: 523.

${ }^{99}$ Ellen G. White, The Story of Patriarchs and Prophets (Nampa, ID: Pacific Press, 1958), 125. 
In order for Abraham to be a channel through whom the world was to receive a

blessing, he had to experience the blessing of God first. These texts allude to the fact that

the Father of faith was to develop a relationship with God and experience salvation

before becoming a channel of hope to others. Abraham's move from his fatherland was

necessitated neither by poverty, nor adventure, but was initiated by God. ${ }^{100}$

Subsequent patriarchs, such as Isaac, Jacob, and others, were also invited to

continue the legacy of Abraham by being God's followers. Even though rebellion and

apostasy marked the history of some, most of those called responded to God's invitation.

These became light-bearers, beacons of hope to a superstitious and idolatrous world. ${ }^{101}$

${ }^{100}$ Exell, “Commentary on Genesis 12:1-3," 526.

101 James Atwell, The Sources of the Old Testament: A Guide to the Religious Thought of the Hebrew Bible (New York: T and T Clark International, 2004), 37ff. In his comparison of the nomadic Israel's religion, which was mostly conducted at the mobile tents or around the campfire, and that of the Canaanites, Atwell notes that myths and tales of jealousies, intrigues, and exploits of Canaanite gods were recounted at religious ceremonies and as popular entertainment. This was also characteristic of much of the Canaanite and Ancient Near Eastern culture. On the other hand, the Israelite patriarchs had a rich human story to tell around the campfire. In place of tales of gods like Baal, which fascinated and excited their subjects, stories and experiences of Israel's adventures and encounter with Yahweh were remembered. At the campfire were stories of heroes who were a reflection of Yahweh and a revelation of His will. Whereas tasks, life, and festivals were cyclic, seasonal, and repetitive for the Canaanite people, each day was different with unique encounters for the Hebrew. There was emphasis on the significance of people, relationships, and decisions. A sense of pilgrimage, traveling toward a destiny preoccupied the Hebrew mind. God promised protection through unique events, guaranteed the offspring would inherit property, and provided the hope of settlement and land. There was an immediate goal and a distant one. Life was working to an end with a sense of purpose. There was a human story to be told. Even after settling in Canaan after the Exodus, the Hebrew nomads never abandoned their identity as "wandering Arameans" throughout their history. They remained with that experience and never threw off the claim of the desert faith. The Tent religion offered a critique of the established Canaanite religious conventions. Loyalty to Yahweh challenged the perceived unfaithfulness of a relationship with many gods. Inventions like cultic prostitution that were practiced in religious meetings conflicted with the strict morality of the Hebrew clan. Thus the Hebrews became a leavening agent within their cultural context because they retained the sense of transition. They never forgot that their identity was bound up with being wandering Arameans. The unique experience of the Exodus under Moses played a major role of ensuring a lasting relationship with God in the midst of idolatry and rebellion. 


\section{Called for Mission}

The call of Abraham stated that through him all the nations of earth would be blessed (Gen 12:1-3). The theme of blessing stands out throughout the rest of the story, being referenced more than eighty-eight times in Genesis alone. ${ }^{102}$ This blessing was a gift from God that would be mediated through a human being. Abraham set out as a nomad, without knowing where he was going (Heb 11:8-9). He lived in tents as an alien in the land of promise, with Isaac and the succeeding heirs of the Messianic promise. This promise given to Abraham was reiterated by God (Gen 26:24; 27:29) in the years that followed.

Later, Moses was called while tending flocks in the wilderness of Midian (Exod 3:1-10) and entrusted with the task of liberating Abraham's descendants, the Israelites, from slavery in Egypt and bringing them to the Promised Land. This came about through a forty-year-long journey of wandering in deserts and waste lands.

\section{Protected by God}

God renewed the promise to protect Abraham and his descendants through a covenant with Israel, as they wandered near Mt. Sinai (Exod 19-20). Although they faced hardships such as hunger and thirst, and often complained against God, the Israelites realized their protection as God accompanied them on their journey to the Promised Land. God dealt with them tenderly, giving them manna for food (Exod 16:1-4), water from a rock (Exod 17:6), and clothes and sandals that did not wear out (Deut 8:4). ${ }^{103}$ In

${ }^{102}$ Genesis 12:1-3, The New Interpreter's Bible (NIB).

${ }^{103}$ Ellen G White, Prophets and Kings (Nampa, ID: Pacific Press, 1943), 312. 
addition to these provisions, their security was guaranteed as the fierce tribes of Amorites, Moabites, and Philistines were conquered by God on Israel's behalf.

\section{"Wandering," a Biblical Imagery}

The act of wandering is presented in Scripture as a way of life through which God establishes a saving relationship with humanity. The Old Testament emphasizes the act of walking (a synonym of wandering) as an experience believers should desire. "Blessed are they whose ways are blameless, who walk according to the law of the Lord. Blessed are they who keep his statutes and seek him with all their heart. They do nothing wrong; they walk in his ways" (Ps 119:1-3). The one who is not shaken is "he whose walk is blameless and who does what is righteous, who speaks the truth from his heart" (Ps 15:2, 5). Those who walk in God's ways experience restoration and strength, and God guides them along the path of righteousness (Ps 23:3).

Christ's incarnated life on earth is also viewed as an exodus of the Son from the Father into the world and His later return to the Father. His earthly life was characterized by wandering: His flight to Egypt, return to Nazareth, annual pilgrimage to the temple in Jerusalem, and His entire public ministry were filled with movement from one region to another to the extent that He said, "The Son of Man has nowhere to lay his head" (Matt $8: 20)$.

In the New Testament, wandering is also presented as a worthwhile characteristic for believers awaiting the heavenly home. The apostle Peter exhorts Christians to be strangers, sojourners, and pilgrims (1 Pet 1:1, 4, 17;2:11). To him, believers are like the patriarchs, nomads living in a strange land, looking for a spiritual city. John also appeals 
to believers not to love the world nor the things in it (1 John 2:15). The world should not feel like a permanent home for those aspiring for a heavenly one.

Thus, although nomads are often abandoned by the world, they are not abandoned by God, who provides the necessities they need for survival. Their lifestyle of wandering is a permanent and symbolic reminder to trust God in life's journey toward eternity. The example set by nomads should inspire the Christian Church to develop a life dependent on God's provision for basic human needs, along with eternal salvation.

The biblical narrative about the relationship between God and nomads indicates that God's people, both settled and nomadic, are to have a mentality of travelers being led by their Herdsman. The close ties Yahweh had with biblical nomads, demonstrate God's desire to befriend the travelers and to use them to reach others. God's relationship with nomads also marked the lifestyle of the early church and should inspire modern-day believers to be travelers and pilgrims in an unfriendly world and to rally themselves under the care of their master shepherd, Jesus Christ.

\section{Mission and Nomads}

Mission encompasses God's eternal activities as recorded in Scripture, from creation to the final elimination of sin and reconciliation with humanity. ${ }^{104}$ God's initiative is to save the world through Jesus. Mission invites men and women, then, to be a part of this saving plan. Just as God sent the patriarchs, the prophets, Jesus, and the apostles, God now sends the Church to accomplish these salvific purposes. George W. Peters asserts that God has chosen human instruments to accomplish the task in human

${ }^{104}$ Christopher J. H. Wright, The Mission of God (Downers Grove, IL: InterVarsity, 2006). 
hearts within a human society surrounded by a human environment. ${ }^{105}$ Tennent also describes missions as the specific and varied ways in which the church crosses cultural boundaries to reflect the life of the triune God in the world and, through that identity, participates in His mission, celebrating through word and deed the breaking of the new creation. $^{106}$

The mandate to proclaim God's will among nomadic people is therefore rooted in God's desire to save all humanity, regardless of their lifestyle or culture. This universal nature of mission ${ }^{107}$ that is demonstrated by God sending the Son and the Holy Spirit to accomplish the plan of salvation indicates that all humans are recipients of the merits of Christ's sacrifice. The call of nomadic figures such as Abraham and other Old Testament patriarchs, ${ }^{108}$ who wandered about with their livestock, confirm that all people, including those without permanent settlements, are to be recipients of the Good News of the gospel.

\section{Motivation for Mission}

Nomads are very much a part of God's saving plan for all nations. Since God was deeply engaged with nomads as evidenced in Scripture, present-day nomads like the Pokot deserve every chance to hear of salvation. ${ }^{109}$ Yet the nomads are among the

${ }^{105}$ George W. Peters, A Biblical Theology of Missions (Chicago: Moody, 1972), 163.

106 Tennent, Invitation to World Missions, 59.

${ }^{107}$ David Bosch, Transforming Mission: Paradigm Shifts in Theology of Missions (Maryknoll, NY: Orbis, 1991), 1.

108 Jirí Moskala, “The Mission of God's People in the Old Testament," Perspective Digest 16, no. 2 (2008), accessed December 5, 2016, http://www.perspectivedigest.org/article/38/archives/16-2/missionof-god-s-people-in-the-old-testament.

109 "What is the Nomadic Peoples Network?” Nomadic Peoples Network, accessed July 1, 2016, http://nomadicpeoples.net/what-is-the-nomadic-peopls-network/. 
world's most misunderstood and marginalized people, without a voice or representative in decision-making circles. ${ }^{110}$ Living in the most remote and undeveloped parts of the world, where communication and facilities are limited or non-existent, has contributed to their state of being neglected. Because of prejudices held toward nomads and the inhospitable areas they occupy, missionaries from settled backgrounds continue to have difficulty witnessing to nomads, with few wanting to evangelize or live among them. This makes nomads the last and least likely group to hear the gospel. ${ }^{11}$

\section{Adventist Mission and Nomads}

The goal of SDA mission, which is grounded and embedded in the context of the Church's unique understanding of Scripture, is to make disciples of all people. The mandate to impart the gospel is based on the context and interpretation of the three angels' messages of Revelation 14:6-12, ${ }^{112}$ which calls for the proclamation of the gospel to "every nation, tribe, tongue, and people" (Rev 14:6). ${ }^{113}$ Communicating the everlasting

\footnotetext{
${ }^{110}$ Hunter, "Think Nomadic," 9. See also "Chronic Marginalization, Fragmentation, Encroachment, Lack of Land Rights: Pastoralists in Africa among Poorest in World, Indigenous Forum Told," United Nations Meetings Coverage and Press Releases, May 23, 2013, accessed October2, 2016, http://www.un.org/press/en/2013/hr5135.doc.htm.

111 "What Is the Nomadic Peoples Network?"

112 General Conference of Seventh-day Adventists, Seventh-day Adventists Believe (Silver Spring, MD: General Conference of Seventh-day Adventists, 2005), 233. While believing that salvation is all of grace and not of works, Adventists affirm that the fruit of salvation is obedience to the commandments of God, which develops Christian character and results in a sense of well-being. These principles of God's law which are embodied in the Ten Commandments and exemplified in the life of Christ express God's love, will, and purposes concerning human conduct and relationships and are binding upon all people in every age. For Adventist, the commandments are the basis of God's covenant with His people and the standard of judgment. Through the agency of the Holy Spirit they point out sin and awaken a sense of need for a Savior.
}

${ }^{113}$ Rajmund Dabrowski, ed., SDA Church Statements, Guidelines and other Documents (Hagerstown, MD: Review and Herald, 2010), 1. 
gospel across the various cultures of the world, encouraging people to accept Jesus as a personal Savior and unite with His worldwide Church, has been and continues to remain the main task of SDA mission. This mission also includes discipling converts to serve God among their people and prepare others for Christ's soon return.

In order to be relevant and to meaningfully proclaim the gospel in a multi-cultural context, the Church must be intentional in communicating the gospel in light of cultural diversity. By seeking to contextualize its approach, SDA mission realizes that contextualization efforts must be faithful to the Scriptures, guided by the Spirit, and relevant to the host culture. ${ }^{114}$

\section{Methodology}

From the beginning of the SDA movement, preaching, teaching, healing, and discipling have remained the main missional strategies to reach people with the gospel. ${ }^{115}$ In spite of changing times and cultural variations, these approaches have continued to be used in various parts of the world to evangelize diverse groups of people, including the nomads.

Although there are no available records of mission activities specific to nomads, various attempts have been made by local SDA communities, agencies, independent organizations, and individuals to reach these wandering populations. Organizations such

114 "Roadmap for Mission," Seventh-day Adventist Church, October 13, 2009, accessed September 31, 2016, https://www.adventist.org/en/information/official-statements/documents/article/go//roadmap-for-mission/.

115 General Conference of Seventh-day Adventists, "Mission Statement of the Seventh-day Adventist Church," October 13, 2014, accessed November 19, 2016, http://www.adventist.org/information /official-statements/statements/article/go/0/mission-statement-of-the-seventh-day-adventist-church/. 
as Adventist Frontier Missions have been foremost in reaching nomads around the world. ${ }^{116}$

Seventh-day Adventist mission to nomadic people should, first, be guided by the Almighty God who works directly with nomads to bring them to salvation. Second, missionary agents, the Church, and other movements are invited to join the work of God among nomads, revealing the Lord's love and grace through word and deed. Third, the Scriptures, which are a revelation of God's past dealings with humanity and His future intentions, should inform mission methods and strategies employed to reach nomadic people. Fourth, mission to nomads should be contextualized to reach the deepest levels of nomadic cultures.

\section{Summary}

Adaptation of the concept of worldview from its philosophical and theological roots of the eighteenth century into the various disciplines where it is applied has resulted in a better understanding of human cultures. In missions, worldview is useful as an analytical tool that reveals deep levels of culture important to the process of conversion. Understanding a people's worldviews also aids in effective communication of the gospel.

Nomadic peoples are among the cultures who can benefit most from worldview research. Throughout the world, they are still considered some of the least reached by the gospel. Although the Scriptures show that God worked with and through nomads to reveal the plan of salvation, a limited understanding of their culture has often resulted in

\footnotetext{
${ }^{116}$ For a detailed record of Adventist Frontier Missions (AFM) projects, see "Who We Serve," Adventist Frontier Missions, accessed December 2, 2015, http://www.afmonline.org/serve/projects/all. Among others, note the Himba of Namibia Project, at "Himba Frontier Missions, accessed December 2, 2016, http://www.afmonline.org/serve/detail/himba.
} 
inappropriate witnessing methods, which is a probable cause of their rejection of Christian influences. Christian witness to nomads should, therefore, be considerate of their cultural values if sustainable presence is to be achieved.

Since nomads are not an exception in the plan of salvation, SDA mission is challenged to increase its efforts to witness to these communities. The energies, resources, and sacrifices that are directed to other people groups should also be devoted to reaching nomadic communities.

The following chapter examines the socio-cultural organization of the Pokot, including a brief sketch of Christian mission history among them, as a foundation to studying their worldview. Since most African societies share common historical and cultural themes, a review of the migration and settlement of Kenya's tribal societies is given at the beginning to establish the context of the study. 


\section{CHAPTER 3}

\section{SOCIO-CULTURAL ANALYSIS OF THE POKOT}

\section{Introduction}

In spite of the large population and cultural diversity that characterize African communities, most of the groups share similar cultural ties and an ancestral heritage. ${ }^{1}$ Close encounters experienced during migration and settlement in the past played a role in shaping their socio-cultural existence. To study African communities in isolation, as evidenced by the Limited Comparative Approach, ${ }^{2}$ denies the connections and parallels that exist between them. Such attempts are "fiercely particularistic" and likely to provide only a part of the story. ${ }^{3}$ It is therefore necessary to review the nineteenth century migration experience of the East African people as a precursor to exploring the sociocultural structure of the Pokot community.

\section{Migration and Settlement of Kenyan Peoples}

Historical records, mostly from the sixteenth to the nineteenth centuries, indicate

\footnotetext{
${ }^{1}$ Anthony Appiah and Henry Louis Gates, Encyclopedia of Africa (Oxford, UK: Oxford University, 2010), 1: 440.

2 The Limited Comparative Approach is one of multiple scientific approaches to studying humans. It was popular among the first generation pioneer anthropologists to study African people groups in isolation of one other. See Udobata R. Onunwa, A Handbook of Methodologies of African Studies (Pittsburgh, PA: Red Lead, 2010), 50.

${ }^{3}$ Ibid.
} 
that most regions of the African continent were preoccupied with the migration and settlement of people. ${ }^{4}$ Widespread movement of tribal communities from diverse locations was dictated by numerous causes and experienced across the region. ${ }^{5}$ In Eastern Africa, migration activities continued and intensified until the early part of the twentieth century.

Written and oral history indicate that in addition to the Bantu people, ${ }^{6}$ who moved from Central Africa to the eastern and southern parts of Africa, large groups of Nilotic ${ }^{7}$ and Cushitic groups also moved from the northeast, mostly from Egypt, Ethiopia, Somalia, and Sudan. ${ }^{8}$ Their dependence on the natural resources of the Nile River precipitated migration southward into Kenya, Uganda, and other neighboring countries where they eventually settled. In the process, some indigenous people who occupied

\footnotetext{
${ }^{4}$ For a more comprehensive migration history of African peoples, see Andrea L. Stanton and Peter J. Seybolt, eds., Cultural Sociology of the Middle East, Asia, and Africa: An Encyclopedia (Washington, DC: Sage, 2012), 35-40; Mary Fitzpatrick, Tim Bewer, and Matthew Firestone, East Africa (Melbourne, Australia: Lonely Planet, 2009), 25-28.

${ }^{5}$ Diseases and epidemics that afflicted flocks, internal feuds and external attacks, adventure, population pressure, and the need for fresh grazing land and water for herds are generally cited as reasons that triggered these movements. Julius Makong'o and Kizito Muchanga, Peak Revision K.C.S.E. History \& Government (Nairobi, Kenya: East African Educational, 2006), 28-29.

${ }^{6}$ Large groups of communities are believed to have descended from the Cameroon highlands in West Africa. Their widely spoken language in Central, Eastern, and Southern Africa bare a common suffix $n t u$ to the nouns which mean group as a whole or a place characterized by the presence of many items. Philip M. Peek and Kwesi Yankah, eds., "The Bantu," African Folklore: An Encyclopedia (New York: Routledge, 2004), 902; Ineke Smeets, A Grammar of Mapuche (Berlin, Germany: Walter de Gruyter, 2008), 109.

${ }^{7}$ Nilotes are several related communities in Central, Eastern, and Southern Africa who are believed to have descended from Sudan or the Ethiopian highlands along the Nile River. They are divided into plain, river-lake, and highland Nilotes based on their economic subsistence. They also share similar cultural traits and speak Nilotic languages. Alan Barnard and Jonathan Spencer, "Africa: Nilotic," Encyclopedia of Social and Cultural Anthropology (New York: Routledge, 2002), 10.

${ }^{8}$ Beneah Manyuru Mutsotso, "Conflict and Social Change: The East Pokot Pastoralists Adjustment to Conflict," American International Journal of Social Science 2, no. 8 (December 2013): 126.
} 
these areas disappeared through assimilation, displacement, or war, or they united with others to form new communities. ${ }^{9}$

The Pokot, also known as the Pokoot, Pakot, or Suk in early literature, ${ }^{10}$ are among the communities that emerged from that nineteenth century migration experience. Linguistic similarities, coupled with oral and written history, indicate that this community is closely linked to Nilotic groups who currently reside in Sudan and Ethiopia and those who moved southward into Uganda, Kenya, and Tanzania.

\section{Previous Research on the Pokot}

Research on the Pokot community that was helpful in this study is based on early studies by Harold Schneider, beginning in 1953. His doctoral dissertation, "The Pakot (Suk) of Kenya with Special Reference to the Role of Livestock in their Subsistence Economy," examined the Pokot subsistence economy and the value of cattle to their livelihood. ${ }^{11}$ Pokot male values and how they are intertwined with the practice of possessing livestock are among Schneider's research highlights. In 1955, he also wrote on the Pokot and other Kalenjin societies' socio-economic organization and concluded that the strict socio-political structures which characterize these groups, are the major reason for their historical resistance to change.

\footnotetext{
${ }^{9}$ Karega Munene, Holocene Foragers, Fishers and Herders of Western Kenya (Lansing, MI: University of Michigan, 2002); Makong'o and Muchanga, Peak Revision, 22-32.

${ }^{10}$ Selma Jeanne Cohen, ed. International Encyclopedia of Dance (Oxford, UK: Oxford University Press, 1998), 209.

${ }^{11}$ Harold K. Schneider, "The Pakot (Suk) of Kenya with Special Reference to the Role of Livestock in their Subsistence Economy” (PhD diss., Northwestern University, IL, 1953).
} 
According to Schneider, the Pokot people value and desire to continue their traditional ways of life, which incorporate the socio-economic structures created by tororot (God). ${ }^{12}$ Kjartan Jónsson also notes that the strong adherence to their belief system explains the natural fear among the Pokot that the fundamental principle of poghishyo (peace and harmony) might be jeopardized if change were accepted with unforeseen consequences and misfortunes for both animals and humans. ${ }^{13}$

Schneider's work was complemented by Francis P. Conant who in 1965 wrote about the Korok-inter-dependent community units or neighborhoods which shape Pokot culture, physically and socially. ${ }^{14}$ In a physical sense, Conant noted that the scattered Pokot homesteads reflect the relative intensity with which the different environments may be worked by farming and herding. Socially, the Pokot herders and farmers are connected through intermarriage, exchange of subsistence produce, and shared common rituals and local councils. ${ }^{15}$

In 1991, Gerrit Van Steenbergen explored the concept of sin, ngoki, among the Pokot. ${ }^{16}$ He found that the concept of sin is vaguely described and is mostly context dependent, compared to the comprehensive Christian understanding. In the absence of

\footnotetext{
${ }^{12}$ Harold K. Schneider, "Pakot Resistance to Change," in Continuity and Change in African Cultures, ed. William R. Bascom and Melville J. Herskovits (Chicago, IL: University of Chicago, 1959), 158.

${ }^{13}$ Kjartan Jónsson, "Pokot Masculinity: The Role of Rituals in Forming Men” (PhD diss. University of Iceland, 2007), 17.

${ }^{14}$ Nathan J. Corbitt, "Korok: A Variable Unit of Physical and Social Space among the Pokot of East Africa," American Anthropologist 67, no. 2 (1965): 429-434.

${ }^{15}$ Ibid., 433.

${ }^{16}$ Gerrit Van Steenbergen, "Translating 'Sin' in Pokoot: An Analysis of the Problem," The Bible Translator 4, no. 42 (October 1991): 431-437.
} 
ngoki (sin), Steenbergen observed that there is poghishyo (peace and harmony). This peace entails living harmoniously in the community without "bad words" that disturb relationships between humans and nature. This peace also includes the absence of "bad birds" singing, threats from wild animals, human and animal sickness, and cattle raiders from the Turkana. Concurrently, poghishyo, is characterized by people standing firm like Mt. Mtelo and a god, Tororot, who is not angry and who is looking down upon people from Mt. Mtelo with favor, providing the blessings of having many children, healthy calves and lambs, and sufficient rainfall. These characteristics of poghishyo are desired by all community members. ${ }^{17}$

An illuminating and wide-ranging historical account of the Pokot people was chronicled by David K. Patterson in 1969. His research work titled The Pokot of Western Kenya, 1910-1963 highlights the coming of Western missionaries to the region and describes the challenges encountered by colonial powers in their effort to introduce Western education and agriculture to a people essentially resistant to change. ${ }^{18}$ Apart from Patterson's historical study, broad research was later conducted by others who utilized the linguistic, archeological, and ethnographic materials of Christopher Ehret. ${ }^{19}$

Michael Bollig's An Outline of Pre-colonial Pokot History deals with a history of the Eastern Pokot, those living in the Nginyang Division of Baringo County. His fieldwork between 1987 and 1989 in Baringo District (now Baringo County), concluded

${ }^{17}$ Steenbergen, "Translating Sin in Pokot," 433.

${ }^{18}$ David K. Patterson, The Pokot of Western Kenya, 1910-1963: The Response of a Conservative People to Colonial Rule (Syracuse, NY: Syracuse University, 1969).

${ }^{19}$ Christopher Ehret, "Outlining Southern African History: A Re-evaluation A.D. 100-1500," Ufahamu: A Journal of African Studies 1, no. 3 (1972): 9-28. 
that the East Pokot originated from the hilly regions of the northern Cherengani and Sekerr ranges in Western Kenya, according to oral traditions provided by clan elders. ${ }^{20}$

In 1992, Barbara A. Bianco wrote her dissertation, “The Historical Anthropology of a Mission Hospital in Northwestern Kenya.” In her research, Bianco describes missionary work that received little attention in anthropological and historical literature concerning Christian evangelism during colonial rule. Her field and archival research argues that the incorporation of a Western medical institution into a non-Western therapeutic landscape is best understood in terms of the changing politics of vulnerability that linked European newcomers and African natives. ${ }^{21}$

Other studies include anthropologist Elizabeth Meyerhoff's dissertation titled “Socio-economic and Ritual Roles of Pokot Women." In responding to popular views of the time that Pokot women were dominated by men, she outlines various rituals associated with Pokot women's sexuality as a source of power over men. ${ }^{22}$

In 2001, Anne Kisaka Nangulu researched how the Pokot have over the years utilized limited resources to produce food in an arid environment with inadequate amounts of water and scanty vegetation. ${ }^{23}$ She argues that in addition to outside relief and

${ }^{20}$ Michael Bollig, "An Outline of Pre-Colonial Pokot History,” Afrikanistische Arbeitspapiere, no. 23, (1990): 73-91.

${ }^{21}$ Barbara Bianco, "The Historical Anthropology of a Mission Hospital in Northwestern Kenya" (PhD diss., New York University, 1992).

22 Elizabeth L. Meyerhoff, "The Socio-economic and Ritual Roles of Pokot Women" (PhD diss., Cambridge University, 1982).

${ }^{23}$ Anne Kisaka Nangulu, Food Security and Coping Mechanisms in Marginal Areas: The Case of West Pokot, Kenya, 1920-1995 (Leiden, Netherlands: African Studies Centre, 2009). 
government aid, which at times is politically influenced ${ }^{24}$ the adaptation of traditional coping mechanisms like herding, hunting, gathering, and trading activities have significantly contributed to food security among the Pokot over the years. Her work was followed by Kjartan Jónsson’s “Pokot Masculinity: Roles of Rituals in Forming Men” in 2006. ${ }^{25}$ Jónsson sketches a series of age-set Pokot rituals from birth to death and shows how these shape men as credible members within Pokot culture.

Other recent studies include "Beads of Empowerment: The Role of Body Art in Challenging Pokot Gender Identities" by Jennifer Fleischman. ${ }^{26}$ Her 2012 thesis reveals how Pokot female body art identifies a woman's beauty, husband, and social rank among the Pokot community through color, pattern, and mass. Recently, Irene Chepoisho Tulel has explored the role of women in peace-building in pastoral conflicts with particular reference to the Pokot women of the Sigor region or West Pokot County. She argues that although women are essential to the community and entrusted with various roles including leadership, they are generally viewed as "not very visible in peace efforts."27 It is therefore evident that efforts have been made to study Pokot culture from various perspectives. However, it is also evident that in spite of these studies, little

${ }^{24}$ Ibid., 233.

25 Jónsson, "Pokot Masculinity."

${ }^{26}$ Jennifer R. Fleischman, "Beads of Empowerment: The Role of Body Art in Challenging Pokot Gender Identities” (master's thesis, Georgia State University, 2012).

${ }^{27}$ Irene Chepoisho Tulel, "Women and Peace-Building in Pastoral Conflicts: A Case Study of Pokot Women in Sigor Region of West Pokot County, 1984-2000" (master's thesis, Nairobi University, 2013), 1 . 
attention has been given to a comprehensive study on the deep underlying layers of Pokot culture and its implications for Christian ministry.

\section{Geographical Locations}

The Pokot are primarily found in two East African countries, Kenya and Uganda, where they are well established in the Western and Eastern regions respectively. ${ }^{28}$ In Kenya, the community inhabits the Northwest region occupying the highlands and plains of West Pokot County (Figure 1), which comprises the Pokot South, Pokot North, Pokot Central, and West Pokot sub-counties. The Eastern Pokots reside in the East Pokot Subcounty of Baringo County, in the former Rift Valley province. Neighbors to the Kenyan Pokot are Uganda's Pokot, who inhabit the Amudat district in the Eastern region neighboring Kenya.

Additional significant numbers of young Pokots reside in various cities and towns, such as Kitale, Kapenguria, Narok, Eldoret, Kisumu, and even the capital Nairobi. ${ }^{29}$ They include youth from various pastoral communities who often migrate to urban centers in search of menial jobs to supplement their families' livelihood due to food shortages caused by frequent droughts. ${ }^{30}$ This particular migration is a social

\footnotetext{
${ }^{28}$ Julaina A. Obika and Harriet K. Bibangambah, "Climate Change and Peacebuilding among Pastoralist Communities in Northeastern Uganda and Western Kenya," in Conflict and Peacebuilding in the African Great Lakes Region, ed. Kenneth Omeje and Tricia Redeker Hepner (Bloomington, IN: Indiana University, 2013), 141-144.

${ }^{29}$ Gufu Oba and Walter J. Lusigi, An Overview of Drought Strategies and Land Use in African Pastoral Systems (London, UK: Overseas Development Institute Agricultural Administration Unit, 1987), 13.

${ }^{30}$ Mutsotso, "Conflict and Social Change," 126; Jonathan Baker and Tade Akin Aina, The Migration Experience in Africa (Uppsala, Sweden: Nordic Africa Institute, 1995).
} 


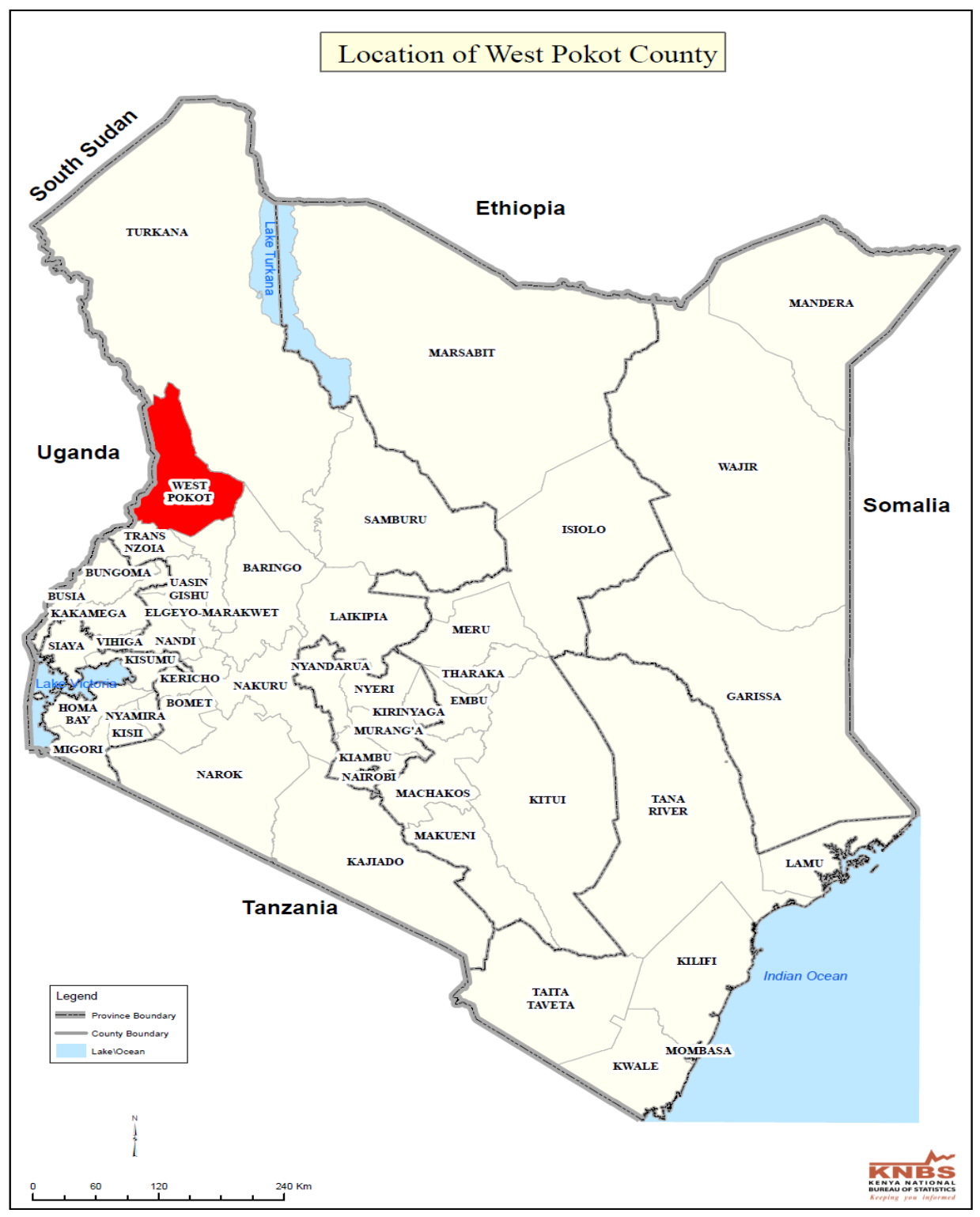

Figure 1. Map of Kenya Showing West Pokot County. Taken from "First County Integrated Development Plan, 2013 - 2017," County Government of West Pokot, accessed July 31, 2016, http://www.westpokot.go.ke/uploads/CIDPfinaldraft.pdf. 
transformation that is common among Kenyan pastoralists and is also experienced across sub-Saharan Africa. ${ }^{31}$ These young people work as night guards in private homes or in business entities while the elderly and children are left in rural areas. Thus, although the Pokot are primarily found in Western Kenya and Eastern Uganda, they can also be found beyond these designated boundaries.

\section{Population}

As indicated in Chapter 2, establishing the nomads' population numbers is a continual challenge not only for governments but also for organizations and agencies working among them. Dissimilar figures frequently provided by agencies involved in development programs in the region ${ }^{32}$ are believed to be a result of periodic movements beyond borders in search of grass and water for animals, which becomes a major hindrance in articulating exact numbers during the national censuses. However, as a consequence of new national political structures that have established stronger regional county governments in charge of local administration and development, ${ }^{33}$ consistent working numbers are now emerging.

\footnotetext{
${ }^{31}$ Chukwuedozie K. Ajaero and Patience C. Onokala, "The Effects of Rural-Urban Migration on Rural Communities of Southeastern Nigeria," International Journal of Population Research (2013), accessed November 22, 2016, http://dx.doi.org/10.1155/2013/610193.

32 Billow Kerrow, "Census Circus and the Need to Independently Audit Results," East Africa Standard Digital, September 5, 2010, accessed September 24, 2016, http://www.standardmedia.co.ke /?id=2000017690\&catid=612\&articleID=2000017690; Saverio Krätli and Jeremy Swift, "Counting Pastoralists in Kenya," (Nairobi, Kenya: DLCI/REGLAP, 2014), accessed September 6, 2016, http://www .fao.org/disasterriskreduction/east-central-africa/documents/detail/en/c/4148/.

33 The 2010 Constitution of Kenya, which replaced the 1969 constitution, introduced a new normative framework of administration with devolution of power from the central government to fortyseven regional county governments headed by an elected governor and senate, among other gains.
} 
The West Pokot County government estimates that there are 640,000 Pokot people in West Pokot County alone. ${ }^{34}$ In Baringo County, out of the 560,000 Baringo County residents, 150,000 are presumed to be Pokots who inhabit East Pokot sub-county. The number of Pokots along the Kenya-Uganda border and those in urban centers across the region but who occasionally reunite with their families and are still attached to the Pokot culture is largely unknown. Other sources of population numbers include the Joshua Project, which estimates that there are 726,000 Pokots in Kenya. ${ }^{35}$

\section{Origins and Historical Development}

Unlike most African tribal communities who trace their origins chronologically to a common ancestry, accounts of Pokot origin are vague and mostly dependent on oral sources provided by the community's elders. ${ }^{36}$ This ambiguity has resulted in a multiplicity of theories regarding Pokot origins, as evidenced by their stories and literature. One popular theory suggests that the Pokot are an assimilation of various Kalenjin sub-tribes, a larger Nilotic community that comprise Nandi language speakers. ${ }^{37}$

\footnotetext{
${ }^{34}$ County Government of West Pokot, "First County Integrated Development Plan 2013-2017," accessed July 31, 2016, www.westpokot.go.ke/docs/CIDPfinaldraft.docx.

35 "Kalenjin, Pokot in Kenya," The Joshua Project, accessed December 3, 2015, https:// joshuaproject.net/people_groups/14428/KE.

${ }^{36}$ Most studies indicate that Pokot elders have been the chief source of information regarding Pokot origins since documentation of early history of most communities is non-existent. See for example, Michael Bollig, Michael Schnegg, and Hans-Peter Wotzka., Pastoralism in Africa: Past, Present and Future (New York: Berghahn Books, 2013), 293; Bollig, "Pre-Colonial Pokot History," 73-91. Some Eastern Pokot lineages claim their roots to be from the hilly regions of the northern Cherengani and Sekerr ranges in Western Kenya.

${ }^{37}$ Michael Bollig, Risk Management in a Hazardous Environment: A Comparative Study of Two Pastoral Societies (New York: Springer Science and Business Media, 2006), 22.
} 
This assimilation theory is narrated by William Lopetakou, ${ }^{38}$ who claims that the earliest and nuclei members of the Pokot community were the Kimkon who defected from the Tirik, an affiliate group of the Kalenjin. The Kimkon were progressively joined by others during their southward migration as they fought over cattle and grazing land with their powerful neighbors, the Turkana, the Karamojong, and the Maasai. ${ }^{39}$ Armed with spears and bows with poisonous arrows, the Pokot, who were esteemed as fierce fighters defeated and assimilated indigenous tribes like the Ogiek, Senquer, Orkom, Llpkop (Kwavi Masaai), Sekelai, and Sirikwa. ${ }^{40}$ Since then, most of these groups have become either extinct, or were forced to migrate southward to Tanzania and westward to Rwanda.

In addition to wars and expansion which led to the assimilation of the Pokot, a prolonged drought in the late 1800s that ended in the early 1900s contributed to people assimilating into the Pokot community. ${ }^{41}$ The drought significantly decreased the number of livestock, causing great social turmoil, including reduced bride price and postponement of murder compensation. Consequently, destitute and deprived people, chepleng, from neighboring communities joined the Pokot, with their women being married at a substandard bride price. $^{42}$

\footnotetext{
${ }^{38}$ William Lopetakou is a Pokot community elder and historian.

${ }^{39}$ Godfrey Mwakikagile, The People of Kenya and Uganda (Dar es Salaam, Tanzania: New
} Africa, 2014), 17.

${ }^{40}$ Lopetakou, interview by author, Kapenguria, June 11, 2014.

${ }^{41}$ Bollig, Schnegg, Wotzka, Pastoralism in Africa, 127.

42 Ibid. 
Another common theory among most Pokots proposes that their ancestral roots can be traced directly back to Khartoum in Sudan. They argue that the name Khartoum in Pokot means "the river that blocks celebrations" $" 43$ in reference to the period when the Nile River flooded preventing their southward migration and community festivals.

Finally, some authorities consider the Pokot to be one of the larger Karamojong group. ${ }^{44}$ This theory is based on the shared traditional practices common to both communities, such as the celebration of sapana. This ritual requires young morans (warriors) to choose a particular bull that is significant to them and develop an appearance and a name that reflects the bull. These men then sing songs in praise of the bull in order to attract women for marriage. ${ }^{45}$

With the expansion of the larger and more powerful Turkana people, the Pokot moved southward toward the Cherengani hills. Some began practicing agro-farming to supplement their economy. Their warlike and ferocious status continued to characterize them. Swahili traders in the 1860 s reportedly refused to enter Pokot lands for fear of their hostility. ${ }^{46}$

The vague explanation of Pokot origins is summed up by Kjartan Jónsson's words:

${ }^{43}$ Lopetakou, interview.

${ }^{44}$ Nat Dyer, Shadrack Omondi, and Michael Wantsusi, Securing Pastoralism in East and West Africa: Protecting and Promoting Livestock Mobility (London: International Institute for Environment and Development, 2008), accessed September 1, 2015, http.www.pubs.iied.org/pdfs/G03036.pdf.

${ }^{45}$ Ruto Pkalya, Mohamud Adan, and Isabella Masinde, Indigenous Democracy: Traditional Conflict Resolution Mechanisms (Nairobi, Kenya: Greenwood, 2004), 12.

${ }^{46}$ Patterson, Pokot of Western Kenya. 
The Pokot people, as an ethnic group, does not have a myth of common ancestry or origin, nor historical memories of a common past, they have a known history of the last one hundred years or so, share many elements of a common culture and have a sense of solidarity based on the same religion, values and language. Their will to stick together is based on voluntary adherence and identification, loyalty and solidarity. The clans, on the other hand, have myths about their origin in Pokot and migration stories about the journeys from their places of origin to the present home in Pokot and the reason why they moved. ${ }^{47}$

Of these theories of origin, the assimilation theory appears most dependable, mainly because of the shared cultural practices between the Pokot and other Kalenjin groups. Practices such as the ear-piercing of animals, particularly goats and cows, is common among pastoral nomadic communities and is viewed by the elders as a sign of shared ancestry. These symbols are viewed as ports of entry into deeper dimensions of reality and are valued as intermediaries between the human world and the divine. ${ }^{48}$

\section{Divisions}

In spite of the shared culture, the Pokot are divided into two sub-groups based on their locations and occupational practices. Approximately half of them are pastoralists, living in the plains of East Pokot, the Nginyang Division of Baringo County, ${ }^{49}$ and in the lowlands of West Pokot, north of the Kapenguria and Kacheliba constituencies. These are referred to as pipo tich, meaning "livestock people". ${ }^{50}$ They keep herds mainly of cattle,

${ }^{47}$ Jónsson, “Pokot Masculinity,” 25.

48 John Galaty, "Dreams, Symbols, and Totems," New Internationalist Magazine, April 5, 1995, accessed October 2, 2016, http://newint.org/features/1995/04/05/dreams/.

${ }^{49}$ Mutsotso, "Conflict and Social Change," 126-127. Mutsotso examines the beginnings of the East Pokot of Baringo County who were predominantly pastoralists but have made adjustments to include crop farming and beekeeping as a mechanism to settling disputes with their neighbors. The West Pokot of West Pokot County are also either pastoralists, or agriculturalists.

${ }^{50}$ Ciarunji Chesaina and Ciarunji Chesaina Swinimer, The Pokot. The Heritage Library of African Peoples (New York: The Rosen, 1994), 11. 
sheep, and goats, which they depend on for their survival. Recently, camels have become preferred for their resilience during prolonged dry conditions. The other half of the group are called pipo pagh — grain people, ${ }^{51}$ who can be found along the lowlands of Pokotland. In addition to keeping animals, the pipo pagh practice agriculture in areas that are favorable for crop farming. Analyses of the Pokot economy is provided later in this chapter.

\section{Pokot Culture}

Three factors describe the nature and purpose of culture and are worthy consideration when examining Pokot culture. First, no culture is static. Gary Ferraro and Susan Andreatta argue that even though enacted laws and regulations tend to preserve and protect traditional cultural patterns by erecting barriers to outside ideas and influences, "change in culture often occurs, at times at an accelerated pace that makes it difficult to manage the resulting impact." 52 The function of culture as a mechanism for problem-solving between people and the environment requires its adaptation to the physical, the socio-cultural environments, pressure from other cultures, and world

\footnotetext{
${ }^{51}$ Ibid.

${ }^{52}$ Gary Ferraro and Susan Andreatta, Cultural Anthropology: An Applied Perspective (Stamford,
} CT: Cengage Learning, 2014), 41-42. It is also argued that culture is ever evolving in response to new developments within societies or stimulations from the outside. Developments such as new possibilities or options challenge societies to make new choices regarding the ideas or values of a people's worldview. See Patrick Ryan, ed., "Theology Inculturation in Africa: Methods, Praxis, and Mission," (paper presented at the Catholic University of East Africa, Nairobi, 2003), 7, quoted in Rhodian G. Munyenyembe, Christianity and Socio-cultural Issues: The Charismatic Movement and Contextualization in Malawi (Mzuzu, Malawi: Mzuni, 2011), 28. 
development, all of which are always dynamic. ${ }^{53}$ These factors often generate a shift in the beliefs and behavior of a people.

Second, Pokot culture is changing. Although they are widely recognized as cultural loyalists, who are persistently resistant to change, their ways of life today are quite in contrast to previous years. Their food choices, cooking methods, dress codes, religious practices and belief systems, economic activities, political organization, and other areas of social life today are in contrast to their practices of the past. T. J.

O’Dempsey notes this change when he writes,

In recent times, Pokot society has been in a phase of transition, influenced by new opportunities of educational, economic and social interaction, particularly since the completion of a tarmac road through the district in 1983. While many of these changes are undoubtedly beneficial to the community, they have been associated with a disintegration of traditional Pokot society. ${ }^{54}$

Matthias Österle also describes changes in Pokot economic practices, noting that in some Pokot territories, there has been an economic transformation from specialized, highly mobile, and subsistence-oriented cattle herding to sedentary and market-oriented keepers of small stock. ${ }^{55}$ This trend, which is largely influenced by developers, seems to be geared toward diversifying their economy in order to have the Pokot more settled.

The third observation of Pokot culture suggests that in spite of cultural change pressured by outside influences, the Pokot have still maintained a relatively conservative 1996), 169.

${ }^{53}$ Larry L. Naylor, Culture and Change: An Introduction (Westport, CT: Bergin and Garvey,

${ }^{54}$ T. J. O’Dempsey, “Traditional Belief and Practice among the Pokot People of Kenya with Particular Reference to Mother and Child Health: The Pokot People and their Environment," Ann Trop Paediatr 2 (June 1988): 49-60.

${ }^{55}$ Matthias Österle, "From Cattle to Goats: The Transformation of East Pokot Pastoralism in Kenya," Nomadic Peoples 12, no. 1 (Summer 2008): 81-91. 
cultural identity. Traditional practices such as Female Genital Mutilation (FGM), circumcision, sapana, cattle raiding, and belief in spirits are still widespread in the group. ${ }^{56}$ The Pokot are one of the few Kenyan communities who have consistently attracted researchers and tourists because of these enduring, unique, and outstanding traditions.

\section{Rites of Passage}

In various ways, Pokot culture is comparable to that of other Kalenjin groups. Their customs and practices are incredibly similar to those of groups such as the Karamojong, Turkana, and Masaai, from whom they are believed to have descended. ${ }^{57}$ Close association and interaction between these groups is viewed as a channel through which the Pokot acquired some of their shared customs. ${ }^{58}$ As in most African cultures, Pokot cultural practices are manifest in every phase of life-from birth to death. During occasions and events such as births, the celebration of rites of passage, naming, marriage, death, dressing, and harvesting, Pokot culture is highly displayed.

\footnotetext{
${ }^{56}$ Immanuel Lokwei, ed., "Conflict and Cultural Change, The Pokots," Long Mouth Social Commune, May 22, 2012, accessed December 22, 2016, http://longmouthsocialcommune.org/2012 /05/22/chapter-6-conflict-and-cultural-change-the-pokots/. Lokwei argues, for example, that in spite of numerous projects such ranging, disarmament, and sensitization meetings aimed at both solving conflicts and peace-building among Kenyan pastoralists, livestock raiding is still persistent among the Pokot, perhaps even more so than in the past.

${ }^{57}$ John Lamphear, Encyclopedia of African History, ed. Kevin Shillington (New York: Fitzroy Dearborn, 2005), 127-135.

${ }^{58}$ For intertribal interactions and association among the pastoralists, see Michael Bollig, "PreColonial Pokot History," 73-91. Mutsotso also claims that some cultural practices such as singing, the baboon dance, and the sapana rite of passage were learned from Karamojong and the Turkana groups. See Mutsotso, "Conflict and Social Change," 126.
} 
Pokot people undergo a series of rites throughout their lifetimes to mark the beginning and end of each phase of life. These rites, which correspond with one's age, signify important stages of life and point to new expectations, functions, statuses, and roles in the upcoming phase of life. The most significant rites are birth, circumcision, sapana (initiation), marriage, and death.

\section{Birth}

The birth of children is significant among the Pokot. Children are viewed as a blessing from Tororot (god) and their birth proves the manhood and womanhood of those who are newly marrieds. ${ }^{59}$ Birth also signifies the continuity and survival of marriage and the community at large given that divorce is usually high in childless situations.

Celebrations and rituals are conducted by the whole community to ensure the safe delivery and survival of the new-born. This includes a purification ceremony known as parpara which guarantees peace between clans and families for any outstanding quarrel. ${ }^{60}$ The father-to-be stops hunting to avoid being killed by wild animals and also to offer support to the expectant mother. ${ }^{61}$ An experienced midwife, kokeogh, who is usually available in each neighborhood, oversees delivery, assisted by close relatives. ${ }^{62}$

\footnotetext{
${ }^{59}$ Childless parents, especially men, are generally despised and viewed as not being "fully men." Male children are valued since they give societal status to parents and inherit their father's property. See Robert B. Edgerton, "Pokot Intersexuality: An East African Example of the Resolution of Sexual Incongruity," American Anthropologist 66, no. 6 (October 28, 2009); Chesaina and Swinimer, The Pokot, 41 .

${ }^{60}$ Chesaina and Swinimer, The Pokot, 41.

${ }^{61}$ David Reed Shaffer and Katherine Kipp, Developmental Psychology: Childhood \& Adolescence (Belmont, CA: Cengage Learning, 2010), 148.

${ }^{62}$ O’Dempsey, “Traditional Belief and Practice,” 125-134.
} 
As a sign of fertility, the placenta is buried in the goat enclosure, and the new mother is secluded from public for up to three months in order to devote time to her recovery and to the child. ${ }^{63}$ Community values are instilled through stories, imitations, riddles, and role playing, as the child grows.

\section{Circumcision}

The rite of circumcision is one of the most significant ceremonies among the Pokot. Young men between the ages of fifteen and twenty ${ }^{64}$ undergo this rigorous exercise to qualify them to assume the role of morans (warriors), to permit them to marry, or to allow them to assume leadership positions, among other societal roles. During the ceremony, young men are in circumcision camps and secluded in huts, mencha ${ }^{65}$ sometimes for up to three and a half months, undergoing rigorous rituals and mentorship from the community's mature men. ${ }^{66}$ They are also tested for bravery and taught respect for the elderly, the functions and roles of men, the values of the Pokot society, and fighting techniques. At the end of the seclusion, a kipuno ceremony which incorporates them into the community is held to welcome and recognize the new members.

\footnotetext{
${ }^{63}$ Shaffer and Kipp, Developmental Psychology, 148.

${ }^{64}$ Chesaina and Swinimer, The Pokot, 41.

${ }^{65}$ Ibid., 42.

66 Jónsson, "Pokot Masculinity."
} 
On the other hand, young girls of about thirteen years, chemeri, undergo FGM. ${ }^{67}$

This controversial ceremony, which is associated with health complications, including death, ${ }^{68}$ is still valued among the Pokot, who regard the practice as preparation for a girl's transition to womanhood. Apart from being a rite of passage, it is commonly believed that FGM serves as a deterrent to sexual desire that might lead to promiscuity, especially during the months in which husbands are out in the fields tending animals. Although the practice is highly discouraged by both government and health organizations, it is still prevalent in rural and remote areas where government supervision is unavailable or inadequate. ${ }^{69}$

\section{Sapana}

The sapana ceremony symbolizes a young man's transition into adulthood. ${ }^{70}$ It follows the ritual of circumcision and is the most esteemed initiation rite among Pokot men. During the ceremony, each individual chooses a bull, normally provided by an uncle or a friend of the father. After a date is set, notification is given to the community, who assemble to witness the spearing of the bull by the initiate. Blood is collected and

\footnotetext{
${ }^{67}$ Chesaina and Swinimer, The Pokot, 41.
}

68 "Health Complications of Female Genital Mutilation," World Health Organization, accessed July 14, 2014, http://www.who.int/reproductivehealth/topics/fgm/health_consequences_fgm/en/.

69 "Uganda: FGM among the Pokot Heightens HIV Risk," IRIN, accessed July 31, 2016, http://www.irinnews.org/indepthmain.aspx?InDepthID=15\&ReportID=59941.

70 The age for sapana participation varies and is dependent on various aspects. In the case of aging parents with one son, the parents may encourage the son to undergo sapana to enable him to marry so he can bear them grandchildren. Availability of a bull for slaughter is another factor. In cases where a family cannot afford one, a relative or family friend may offer, or else, sapana for an individual is postponed. See J. G. Peristiany, "The Age-Set System of the Pastoral Pokot: Mechanism, Function and Post-Sapana Ceremonies," Africa, no. 21 (1951): 279-302; Siegfried Modola, "Rites of Manhood," Reuters: The Wider Image, accessed February 12, 2016, https://widerimage.reuters.com/story/rites-of-manhood. 
mixed with milk to be drunk by the attendees. Songs, dances, food, and other celebratory activities follow the successful slaughter of the animal. ${ }^{71}$

Functions of sapana include rendering a man eligible for marriage, wider social ties, and integration into a larger age-set. Sapana enables one to become a warrior who conducts cattle raids to increase or to obtain wealth and signifies one's age status at the kerket circle. ${ }^{72}$ It is also after undergoing sapana that individuals are allowed to sit at the elders' council, kokwo, and to preside over community leadership.

\section{Marriage}

Traditional Pokot marriages are mostly arranged. Young girls of about fourteen years old are engaged to their future husbands through secret arrangement by their parents. ${ }^{73}$ A bride price, kandin, composed mostly of cows, the community’s most valued wealth, is given to the bride's family. ${ }^{74}$ Although divorce is uncommon after children are born, it is not unusual for couples to divorce in childless circumstances. Polygamy is common and allowed particularly for men with large herds of cattle.

Since marriage among the Pokot is considered an important social construct, a number of taboos to enforce its significance are observed. These include prohibition of

\footnotetext{
${ }^{71}$ For a comprehensive study of sapana, see Peristiany, "The Age-Set System,"; Jónsson, "Pokot Masculinity," 210-223; "Kenya: Pokot, the Rite of Initiation: Sapana,” Southworld, September 1, 2014, accessed December 20, 2016, http://www.southworld.net/kenya-pokot-the-rite-of-initiation-sapana/.

72 Peristiany, "The Age-Set System."

${ }^{73}$ Chris Pleasance, "Young Women Dragged Away from Their Village for a Dowry of 20 Goats and 3 Camels: Inside the Traditional Tribal Wedding Ceremony That Still Takes Place in Kenya," Daily Mail, December 10, 2014, accessed January 20, 2017, http://www.dailymail.co.uk/news/article-2868693/.

74 Daniel Nganga, "Culture as the Cause of Conflict. A Case Study in West Pokot District, Kenya,” In Fact-is Pax 6, no. 1 (2012): 51-69.
} 
marriage between close relatives, particularly those sharing the same grandparent or from the same clan. ${ }^{75}$ There is also strong discouragement of extra-marital relationships under penalty of death and public shaming of men or women, kilapat, who fail to meet their marriage commitments. ${ }^{76}$

\section{Death}

Death marks the end of life. It is regarded as a terrifying experience. People fear touching the dead bodies of even close relatives lest they contaminate themselves with death. ${ }^{77}$ Even though the Pokot do not believe in life after death, spirits of the dead (oy) are believed to exist, roaming around bushes and near human settlements. ${ }^{78}$ Rituals to appease them in order to avert calamity and maintain a state of peace and harmony (poghishyo) are conducted.

Customarily, foods such as tobacco and milk are placed on the grave to be consumed by the spirits. If forgotten, the ancestral spirits may return to cause calamities such as human and livestock disease. ${ }^{79}$ Other ceremonies include a cleansing ceremony,

${ }^{75}$ Francis P. Conant, "Frustration, Marriage Alternatives, and Subsistence Risks among the Pokot of East Africa: Impressions of Co-Variance,” Anthropological Quarterly 47, no. 3 (July 1974): 314-327; Chesaina and Swinimer, The Pokot, 47.

${ }^{76}$ R. B. Edgerton and Francis Conant, "Kilapat: The Shaming Party among the Pokot of East Africa,” Southwestern Journal of Anthropology 20, no. 4 (1964): 404-418.

77 John Fox, "Pokot Beliefs about Death," CNN, October 20, 1998, accessed December 12, 2016, http://www.cnn.com/TECH/science/specials/africaquest/week3/; "Pokot," World Mission Center, accessed July 25, 2016, http://www.worldmissioncentre.com/index.html; Jónsson, “Pokot Masculinity,” 123-124.

${ }^{78}$ Michael Bollig, Risk Management in a Hazardous Environment, 36.

79 Ibid. 
kilokunogh po karun, that is performed thirty days after death has occurred ${ }^{80}$ It involves the sharing of property, settling of any debts that were left behind, and choosing someone to inherit the deceased's wife and take care of the children.

\section{Political Organization}

The Pokot community is generally considered an egalitarian society where principles of equality and fairness characterize its leadership structure. ${ }^{81}$ A council of elders, kokwo, composed of initiated men, govern collectively the affairs of the local community. This highest socio-political institution for managing conflicts is also found among other pastoralists, such as the Samburu, and is charged with presiding over important tribal decisions, festivals, and religious celebrations, among other duties. ${ }^{82}$ Although all men are eligible to contribute toward decisions on matters such as resource management, only senior ranking men moderate meetings and dominate in decisionmaking. ${ }^{83}$

Next to the kokwo council are the prophets, werkoyon, and a ritual expert, kapolokyon. A werkoyon, who may be male or female, ${ }^{84}$ is believed to be divinely gifted

${ }^{80}$ See Francis Kiyapyap, comment, July 15, 2015 (4:04 am), on "Pokot - Religion and Expressive Culture," accessed July 8, 2016, http:/www.everyculture.com/Africa-Middle-East/Pokot-Religion-andExpressive-Culture.html.

${ }^{81}$ See Michael Bollig, "Staging Social Structures: Ritual and Social Organization in an Egalitarian Society: The Pastoral Pokot of Northern Kenya," Ethnos: Journal of Anthropology 65, no. 3 (2000); Bollig, Risk Management, 35.

82 Jónsson, "Pokot Masculinity, 325.

${ }^{83}$ Bollig, Risk Management, 35.

${ }^{84}$ David Levinson, Encyclopedia of World Cultures: Africa and the Middle East (Boston, MA: Garrison K. Hall, 1995), 285. 
to foresee the future and guides the Pokot on how to alleviate danger. In the case of impending threat from neighboring tribes such as a raid or war, the werkoyon decides what the community should do. Their functions also include advising the community on the best time for initiation, preferably when there is peace since the initiates may not fight when secluded. ${ }^{85}$ The kapolokyon leads out in various rituals, including affirming decisions made by the kokwo.

Although the traditional system of government was more defined during precolonial times, it was overtaken by colonial and post-colonial government structures, which appointed local leaders. These include local chiefs, councilors, members of the County assembly, members of parliament, senators, and a governor. ${ }^{86}$ They oversee the interests of the national government at the local level and form the final authority of leadership. In spite of the administrative structures, the Pokot people continue to recognize the role of clan elders and accord them respect as they solve criminal cases before turning them over to modern courts.

\section{Economic Organization}

Even though they are mostly known for their pastoralism like most of the Kalenjin groups, the Pokot are an agro-pastoral community. ${ }^{87}$ Livestock keeping, which

${ }^{85}$ Bollig, Risk Management, 35.

${ }^{86}$ For more information on the political structures of Kenya, see Kempe R. Hope, "Decentralization and Local Governance," in The Political Economy of Development in Kenya (New York: Continuum, 2011), 152-165.

\footnotetext{
${ }^{87}$ A practice of agriculture that combines growing of crops and raising of livestock.
} 
is still valued as the ideal livelihood, ${ }^{88}$ is practiced alongside crop farming to supplement the income of most families, particularly in regions where the climate is favorable for arable farming.

\section{Livestock Farming}

Historically, the Pokot have been known for animal rearing, and their animals serve many purposes within the community. They are kept as a basic source of food in a region that experiences long periods of drought. Animal products, such as milk, butter, and cheese, supplement the family's food and income. Breeds that can withstand long dry seasons are mostly preferred. Animals also serve the purpose of giving identity and pride to the Pokot. ${ }^{89}$ The famous saying, "Better walk with a cow than with a woman," up the relationship between cows and the self-image of a Pokot man. An individual without animals is considered as a failure or under a curse.

Animals are also essential for religious or communal ceremonies, where they are offered as sacrifices. Rites of passage require rituals and animal sacrifice. ${ }^{91}$ No marriage can take place without a bride price composed of cows. Livestock are also used in exchange for other necessary items that may not be available in the community or are used to pay fines in order to settle cases.

\footnotetext{
${ }^{88}$ Beneah M. Mutsotso, "The Centrality of Cattle in the Social Organization of the East Pokot Pastoralists of North Western Kenya," European Scientific Journal 10, no. 8 (March 2014): 497-507.

${ }^{89}$ Jónsson, "Pokot Masculinity," 187.

${ }^{90}$ Mutsotso, "The Centrality of Cattle," 491.

${ }^{91}$ Mutsotso, "The Centrality of Cattle," 491.
} 
Cows, goats, sheep, and recently camels are the main animals kept by the Pokot. Cows in particular are quite significant because they produce more milk and serve more people when slaughtered. Recent research conducted to evaluate pastoralism as an economic activity in Western Kenya, however, indicates that unlike in the past, the rearing of goats now seems to supersede that of cows because they are more convenient to keep. ${ }^{92}$ The increase in the Pokot population has reduced grazing space leading most households to resort to keeping goats because they consume less than cows. Goats also tend to survive dry seasons better than cows and allow for more frequent sales, thus providing a steadier household income than cows. ${ }^{93}$

\section{Crop Farming}

Besides livestock farming, parts of Pokot land support crop farming. Fertile soil with periodic rainfall and irrigation allows for the growing and production of major Agricultural products such as maize, potatoes, and onions, among other produce. In more productive areas, cash crops like pyrethrum, coffee, and tea are also grown, contributing to family incomes.

92 Österle, "From Cattle to Goats," 81; Aletia C. Imana, "Goat Rearing as a Livelihood Strategy of Turkana: Pastoralism in North West Kenya" (PhD diss., University of The Free State, 2008).

${ }^{93}$ Ibid. 


\section{Pokot Religion}

As observed, "African people are notoriously religious and religion has such a

grip in their entire life, ${ }^{\circ 94}$ Among the Pokot, religion is an essential component of daily life whereby religious ceremonies, rituals, and celebrations are practiced on many occasions. Although many years have elapsed since Christianity was introduced, the majority of the Pokot still practice African traditional religious beliefs. ${ }^{95}$

\section{Religious Practices}

Religion is key to Pokot life. Each step of life is marked with some form of religious practice or ritual characterized by offering of sacrifice, prayers, song and dance, or bowing in holy places. Worship in caves, on mountains, at river-banks, under trees, and at other sacred places is common. Religious practices also include offering of sacrifices to appease deities so as to avert calamities like drought, disease, lightening, invasion of wild animals, and war. These are believed to be consequences of angry deities due to unacceptable human behavior or actions.

${ }^{94}$ See Maurice M. Makumba, "Philosophy and African Traditional Religions," in An Introduction to African Philosophy: Past and Present (Nairobi, Kenya: Paulines, 2007), 166; John S. Mbiti, African Religions and Philosophy (Portsmouth, NH: Reed, 1990), 1.

${ }^{95}$ Mission research indicates that only fifteen to twenty percent are Christians, who still possess traditional beliefs and worldview, and eighty-five percent practice traditional religion. See "Kalenjin, Pokot in Kenya," The Joshua Project; "Pokot," World Mission Center. 


\section{The Divine}

According to Pokot religious beliefs, the divine supreme being is tororot (some literature uses tororut). ${ }^{96} \mathrm{He}$ is believed to dwell above the sky, beyond human dwellings. As the chief deity, tororot is worshiped as the creator of humans and is interested in their affairs. Through prayers and animal sacrifices, his intervention to bless and protect is invoked periodically. Tororot responds by listening to prayers, giving blessings in the form of healthy animals, and averts calamity such as disease, war, drought, and misfortune. He also rebukes, warns, and punishes evil doers. ${ }^{97}$

In addition to tororot (god), are asis (sun), and ilat (rain). ${ }^{98}$ Just as the sun shines light on all corners of the earth, asis is responsible for witnessing human activities on earth. ${ }^{99}$ On the other hand, ilat acts as the messenger of the deities to humans. As a son of the creator (tororot), ilat spills water in the form of rain when asked to fetch. ${ }^{100}$ 2014), 135 .

${ }^{96}$ See, for example, Michael Jordan, Dictionary of Gods and Goddesses (New York: InfoBase,

${ }^{97}$ Harold K. Schneider, The Africans: An Ethnological Account (Upper Saddle River, NJ: Prentice Hall, 1981), 191.

98 "Pokot Religion and Expressive Culture," Countries and Their Culture, accessed July 8, 2016, http://www.everyculture.com/Africa-Middle-East/Pokot-Religion-and-Expressive-Culture.html.

${ }^{99}$ Levinson, Encyclopedia of World Cultures, 283.

${ }^{100}$ Jordan, Dictionary of Gods, 135. 


\section{Religious Officers}

The most important human figure in Pokot religion is the werkoyon (prophet). ${ }^{101}$ A werkoyon, who may be a male or a female, ${ }^{102}$ is a mediator between humans and the divine, receiving messages from Ilat in the form of dreams and visions. A Werkoyon has the ability, given by Tororot, to foresee impending disaster, such as illness, famine, and raids. They also seek to know people's problems and recommend expiation through animal sacrifice in order to ease punishment. ${ }^{103}$

There are also diviners and seers whose functions range from foretelling rain or impending raids, to guiding the community away from danger. ${ }^{104}$ These include the rainmakers, mompokaw, milk diviners, chepsokoyon nyo rosei cho, reader of intestines, pkwanian, and sandal throwers, chepsokoyon kwegh. Using items such as animal intestines and milk, these diviners are able to foretell the future through a skillful reading of patterns formed by these items when spilled. ${ }^{105}$

Finally, there are religious leaders who deal with witchcraft, sorcery, and magic. Ponin, sorcerers, are the most feared because they cause harm to society. Ponin use items such as herbs, dried lizards, sticks, and snake skins, to protect themselves against curses from others while inflicting harm on others because of jealousy. Their work is often checked by a kapolokyon, a witchdoctor whose work is for the benefit of society.

\footnotetext{
101 Jónsson, "Pokot Masculinity," 127; "Pokot -Religion," Countries and Their Culture. 
Kapolokyon, who are usually men, ${ }^{106}$ also use items such as clay and dried larvae to curse wrongdoers and punish sorcerers. They can foretell the future of individuals and are therefore often consulted by people and are paid for their services. ${ }^{107}$

\section{Social Organization}

Unilateral descent groups ${ }^{108}$ and age grades, which are central characteristics of most African societies, ${ }^{109}$ describe the Pokot community as well. Considered a patrilineal society, ${ }^{110}$ the Pokot are "highly structured by descent and age grading." ${ }^{111}$ In spite of existing modern governance mechanisms after independence, the Pokot continue to maintain well-defined social structures ${ }^{112}$ that ensure identity, continuity, respect for elders, maintenance of law and order, and general tribal discipline as it existed in precolonial years. ${ }^{113}$ These structures include a nucleus family that is surrounded by an

106 Ibid., 136.

107 Ibid.

${ }^{108}$ Also known as unilineal descent, unilateral descent establishes group membership from either a male or a female line. See William A. Haviland, Harald E. L. Prins, and Bunny McBride, Cultural Anthropology: The Human Challenge (Belmont, CA: Cengage, 2011), 240.

${ }^{109}$ Francis E. Godwyll, "Migration of Ethnic Groups," in Cultural Sociology of the Middle East, Asia, and Africa: An Encyclopedia, ed. Andrea L. Stanton (Washington, DC: Sage, 2012), 1:37.

${ }^{110}$ Also known as agnatic descent, patrilineal societies trace lineage exclusively from the male side, while in matrilineal societies, descent is traced from the woman. See Bollig, Risk Management, 33.

111 Bollig, "Staging Social Structures,” 341-365.

${ }^{112}$ Brian M. Howell and Jenell Williams, Introducing Cultural Anthropology: A Christian Perspective (Grand Rapids, MI: Baker Books, 2011), 66. Other terms used to denote social structures include social order or social organization.

${ }^{113}$ Emily D. Drani, "Synergy between Modern and Traditional Governance Mechanisms Experiences from Uganda," Mashariki: Culture and Peace Building Journal 1, no. 1 (2014). 
extended family and patrilineal clans that are composed of groups of families. The next section examines some of the Pokot social structures.

\section{The Family}

As a patrilineal society, the Pokot nucleus family is composed of a husband, a wife (or wives in polygamous situations), ${ }^{114}$ and children, all living in the same compound. Separate houses for polygamous wives and grown children are built until after marriage, when the sons move out to embark on their own lives, separate from their parents. ${ }^{115}$ Each family member is governed by regulations and rules that guide behavior and roles.

As heads of families, husbands are the overall administrators with unquestionable authority. Their responsibilities include making major decisions on important family matters, such as presiding over property distribution, negotiation of bride price, division of inheritance, land use, instilling discipline, and maintaining order. ${ }^{116}$ When the time comes to move, this being a norm for nomads, fathers decide when and where to relocate. Respect is accorded to them depending on how large their families are and the number of

\footnotetext{
114 Polygamy is widely practiced by wealthy Pokot men and those of other pastoralist communities. Young girls are engaged to men with many cattle with the goal of fetching income for their families through the bride price and are married as young as fifteen years old. See Courtney Schultz, "Kenyan Pokot People Need Water: Christian Ministry," Baylor Lariat, August 22, 2005, accessed December 25, 2016, http://www.baylor.edu/lariatarchives/news.php?action=story\&story=35050; Alexander Lucie-Smith, ed., Mission Ad Gentes: The Challenge for the Church in Kenya, Occasional paper no. 21 (Nairobi, Kenya: Pauline, 2007), 49; Barton, "Missionary Spotlight-Kenya."

115 Tulel, "Women and Peace-Building," 24.

${ }^{116}$ Philip W. Porter and David R. Faust, A World of Difference: Encountering and Contesting Development (New York: Guilford, 2009), 293.
} 
cows they own. Those with more cows are likely to marry more women because they can afford the bride price, which amounts to several animals. ${ }^{117}$

Pokot mothers undertake family and community responsibilities. In spite of popular notions about the low status of women in African communities, Pokot women are respected and hold special positions, whose duties include the up-bringing of children and providing daily food. They plant grains, weed gardens, and engage in small trades involving the exchange of grains to supplement family food. ${ }^{118}$ During migration, mothers also pack and transport family belongings and assist in the construction of a homestead. Those with many children are held in high regard while those without children are presumed to be cursed.

As members of the family, the children's responsibilities vary depending on gender. Younger boys are responsible for grazing animals closer to home until they become older when, after initiation as morans (warriors), they can travel further to other lands in search of green pastures or to marry. Younger girls stay closer to their mothers, from whom they learn household chores, which include fetching water when available, collecting firewood, and the periodic smearing of houses with mud and cow dung. After undergoing initiation rites, older girls cook and can engage in a mother's work because they are expected to be married and start their own families soon.

In addition to the nucleus family, the extended family includes other relatives such as in-laws, cousins, grandparents, and others who are blood related. Extended families play a significant role in the community. They participate in conflict

\footnotetext{
${ }^{117}$ Pkalya, Adan, and Masinde, Indigenous Democracy, 23.

${ }^{118}$ Porter and Faust, A World of Difference, 293.
} 
management and resolution in matters that transcend the nucleus family. Porror (neighbors) are also supportive members of the community and may be consulted for advice or counsel during disputes. ${ }^{119}$

\section{The Clan}

A collective group of Pokot families form a clan. Research indicates that there are over thirty clans among the Pokot, each having a common ancestor and symbolized by a totem animal. ${ }^{120}$ Clans play significant roles in community life. First, clans are responsible for providing security and defense against invaders such as cattle rustlers who frequently invade the community with sophisticated weapons. Older men and morans spend their nights outside the compounds or among their livestock to ensure safety against outside threats. During migration, several families unite to move as a group to ensure safe traveling and support in case of danger. Men from the clan are expected to stay vigilant.

Second, clans provide a sense of belonging, identity, and continuity for the family legacy. ${ }^{121}$ The Pokot take pride in their clans, as evidenced in the unique tattoos on animal ears, which signify the owners' clan. Third, in addition to the traditional education provided at home by parents, clans are also responsible for educating and instilling community values. During initiation ceremonies that are conducted at the clan level,

${ }^{119}$ Pkalya, Adan, and Masinde, Indigenous Democracy, 23.

${ }^{120}$ Chesaina and Swinimer, The Pokot, 30.

${ }^{121}$ Adoption of new members from other communities through marriage or as economic refugees requires clans to offer an integration base. Eventually these new members become identified as members of the Pokot society. See Kim de Vries, "Identity Strategies of the Agro-Pastoral Pokot: Analyzing Ethnicity and Clanship within a Spatial Framework" (master's thesis, University of Amsterdam, 2007). 66-69. 
younger generations are instructed on various topics that include respect for the elderly, societal beliefs, taboos, and values. An example of a taboo is the prohibition against marriage between two individuals of the same clan.

Fourth, clans also offer the highest institution of conflict management and sociopolitical structure among the Pokot. A council of clan elders, kokwo, is charged with the responsibility of resolving community matters. The kokwo is mostly composed of respected, wise, elderly men who are knowledgeable in community affairs and history, are good orators and public speakers, and are able to use proverbs and wisdom phrases to bring conflicting parties to a truce. Every village is represented in the kokwo, and respected elderly women are allowed to contribute while seated. ${ }^{122}$

\section{Age Sets}

Members of Pokot society are generally organized according to their age in groups often called age sets. ${ }^{123}$ Each age set is composed of individuals born in the same year or season. It is at the age set that much of the traditional education is instilled, especially during initiation ceremonies. Members of each age-set are expected to exhibit specific character traits and behavior. ${ }^{124}$

Disciplinary actions against wrongdoers are administered by age-mates as a warning and deterrent of unwanted behavior among group members. For instance, if one is caught in an act of adultery, after a series of warnings, age-mates are entitled to

\footnotetext{
122 Pkalya, Adan, and Masinde, Indigenous Democracy, 23.

${ }^{123}$ Peristiany, “The Age-set System,” 188-206.

${ }^{124}$ Chesaina and Swinimer, The Pokot, 44.
} 
discipline the individual. Young circumcised men of similar age combine skills to raid neighboring communities for animals and to graze animals as a group beyond the clan borders.

\section{Christian Mission among the Pokot}

Life sketches, diaries, interviews, web sources, oral accounts, and other records of evangelistic activities are the main sources of the history of Christianity among Kenya's pastoralists. Systematic historical documentation of Christian activities in the region is largely unavailable or scantly accessible in historical literature. Analyses of the available sources indicate that the proclamation of the gospel among the Pokot, which began in the middle of the twentieth century, has been conducted by various Protestants, Catholics, lay movements, individuals, and development agencies.

\section{Early Protestant Mission}

The Anglican Church through the Bible Churchmen's Missionary Society (BCMS) was the first documented Christian movement to begin work among the Pokot as early as $1931 .{ }^{125}$ Lawrence Totty, a BCMS missionary pioneer, established work at Kacheliba that year and was later joined by his wife, Annette Tarr, a teacher from England. Among the first activities they engaged in was the translation of the New Testament into the Pokot language, which was completed in 1936 and was published by the Trinitarian Bible Society. At their retirement, Totty and Tarr left twelve churches, fourteen schools, and a number of converts.

\footnotetext{
125 Anglican Church of Kenya, "The Church History," accessed September 1, 2016, http://www.ackenya.org/ack/history.html.
} 
Around this same period, Tom Collins, an African Inland Church missionary pioneer from England, began mission work at Maron in East Pokot and Marakwet. Working under challenging circumstances including a physical ailment, ${ }^{126}$ Collins learned the Pokot language, participated in the New Testament translation, Kisilat nyo rel, spent considerable time walking with Pokot warriors, spent nights in their huts, and tried to reach the neighboring Turkana people from this region. ${ }^{127}$

\section{Catholic Mission}

The Catholic mission followed the Protestant mission initiatives in 1943 when a parish was established at Tartar through the efforts of the Mill Hill Fathers of the Mukumu Parish in Kakamega County. ${ }^{128}$ These early missionaries found the Pokot resistant to Christianity, education, and other developmental work. Later in 1973, the Comboni Missionaries launched mission work at Kacheliba under the leadership of Piero Endie, who was later joined by Antonio Dolzan.

The Comboni Missionary Sisters arrived in $1974^{129}$ and have since been involved with health-related projects in the community. They started a mobile clinic, which proved to be a better means to approach the local population. The mobile clinic reaches remote areas where people cannot travel to centers for medical treatment. This service is a

${ }^{126}$ Mary Honer, Missy Fundi: Kenya Girl (Lincoln, NE: iUniverse, 2003), 292-293.

127 Art Davies, From Foot Safaris to Helicopters: 100 Years of the Davis Family in Missions (Bloomington, IN: iUniverse, 2011), 98; K. N. Phillips, Tom Collins of Kenya: Son of Valour (Nappanee, IN: Evangel House, 2003).

${ }^{128}$ Lucie-Smith, Mission Ad Gentes," 57.

${ }^{129}$ Comboni Missionaries in Kenya, “Kacheliba," accessed December 22, 2016, http://kenya comboni.org/. 
powerful demonstration of Christian care and religious consciousness. Currently, the Comboni Missionary Sisters run maendeleo (development) programs for women, which include classes teaching sewing, hygiene, cookery, and horticulture.

While developing mission buildings and other projects, the first missionaries began to learn the Pokot language, which they used to prepare catechetical materials to assist the catechists. The catechists were mostly young men who had completed school and were well accepted by the children and women.

Some of the goals and accomplishments of the Catholic mission in the region include sponsoring schools in order to facilitate educational opportunities for the Pokot. Individual children are also assisted through sponsorships up to the secondary level. ${ }^{130}$ Other projects include printing and translation of any material that is profitable for pastoral care and assisting people with aid, building schools, nurseries, drilling wells, maintenance of boreholes, and relief during times of drought.

\section{Seventh-day Adventist Mission}

SDA mission among the Pokot began in the early 1980s. According to an oral account provided by Joseph Parklea, ${ }^{131}$ the SDA message first entered Kapenguria, the county capital, when it was introduced by a local, Robert Kamakil. Kamakil had accepted the SDA message in 1955 when it was presented by some Nandi preachers who had come to witness in the region. Kamakil was baptized away from home and later returned to begin a church at Kapenguria, together with his children.

\footnotetext{
${ }^{130}$ Comboni Missionaries, "Kacheliba."

${ }^{131}$ Joseph Parklea, interview by author, Kapenguria, West Pokot, June 12, 2014.
} 
In the Chepararia area, Adventism was introduced by two lay businessmen who were engaged in a tailoring business in the Chepararia Village of West Pokot County. They shared SDA literature with Parklea, which confirmed his long-time conviction that the seventh-day of the week was the Sabbath of the Lord as proclaimed in the fourth commandment (Exod 20:8-11). Parklea began witnessing, and reinforcement came from Pastor Nathan Oyiengo from the Kapenguria district, which by then was a more established church under the Western Kenya Field of SDAs. Through public evangelistic meetings, work expanded mostly in urban centers.

\section{Evangelism Methods}

Historically, SDAs have relied on health, education, and preaching as their main evangelistic methods. This is also the case with the Pokot, where schools, a clinic, and relief efforts are the main approaches employed to reach the people. Employment of Global Mission Pioneers (GMP) and involvement of various lay groups have contributed to SDA work with the Pokot.

\section{Health}

The Chepararia SDA clinic in West Pokot County offers medical care, maternity needs, and healthful living education to the community. Although limited in equipment and trained personnel, due to low wages, ${ }^{132}$ the Chepararia clinic serves a large population who are mostly poor and live a great distance from more well-developed facilities in larger towns. In addition to child delivery services, the clinic also offers

\footnotetext{
132 Tabitha Nasambu, Chepararia SDA clinic nurse in-charge, interview by author, June 25, 2014. She indicated that most nursing graduates leave soon after employment in search of better wages in the cities. Currently, there is only one registered nurse assisted by untrained workers.
} 
assessment and treatment of patients with minor ailments, with referrals of more complicated illnesses to bigger hospitals in Kapenguria.

\section{Education}

A number of primary schools and secondary schools are in operation. They include Chepararia Primary School in Sigor, Borali Adventist Secondary School in Pokot North and Samuel Kim Adventist Secondary School in Pokot Central Sigor Constituency both constructed by the Bicycle Missionary to the World (BMW) lay group. ${ }^{133}$ Even though school enrollment, attendance, and retention of students among the pastoralists is still minimal due to the cultural pressure which requires younger boys to stay home and graze cattle, these schools continue to provide a link with the community. Education is also helpful seeing that students who graduate seek employment in cities and supplement family income.

\section{Global Mission Pioneers}

Mobilization, recruitment, and sending of mission pioneers ${ }^{134}$ have strengthened mission efforts to the Pokot. Drawn mostly from other communities with a few Pokot SDA GMP witness by establishing contacts with local people, learning their culture, and developing loving relationships within the community. With sponsorship from

\footnotetext{
${ }^{133} \mathrm{BMW}$ is a group composed of laypeople and pastors from Korea, living in the USA. They are engaged in evangelism through medical activities as well as development projects in various parts of the East Central Africa Division of Seventh-day Adventists.

${ }^{134}$ Church members who volunteer each year to establish a new congregation within their own culture or that of others by taking advantage of their knowledge of culture and the language and blending with the local people. See, Seventh-day Adventist Church, "Why Global Mission," accessed November 9, 2016, http://adventistmission.gcnetadventist.org/why-global-mission.
} 
individuals and groups such as $\mathrm{BMW}^{135}$ and Missionary Volunteers to Unentered Areas (MVUA), ${ }^{136}$ Global Mission workers visit and pray for the sick, share Bible stories, and when the opportunity opens up, they invite people to commit their lives to God. Global mission work has not been fruitful among the Pokot however. There is no known congregation which has been established through this means. ${ }^{137}$

\section{Relief}

Offering relief is another approach Seventh-day Adventists employ to reach the community. Since Pokot territories are mostly arid with prolonged drought, food relief has enabled contact with the Pokot. Lay groups such as the Pokot Mission Project coordinate with other agencies to supply maize, clothing, water, toys, and other items to meet the needs of the people. ${ }^{138}$

\footnotetext{
${ }^{135}$ Although BMW is engaged in other evangelism activities, such as the construction of the Borali Adventist Secondary School and Samuel Kim Adventist Secondary School, their main focus is to provide bicycles to missionaries to ease mobility. For more information, see Hansoo Kim, "Oregon Koreans Minister in Kenya," GleanerNow, September 1, 2006, accessed September 22, 2015, http://gleanernow.com/news/2006/09/oregon-koreans-minister-kenya.

${ }^{136}$ MVUA seeks to promote, recruit, train, and send volunteer missionaries to un-entered areas like Pokot. Currently, efforts include sponsoring global mission workers to nomads (including five among the Pokot), promoting a spirit of self-support among believers, and assistance in construction of shelters for congregations. For more information, see "What We Do," MVUA -Missionary Volunteers to Unentered Areas, accessed October 5, 2016, http://www.mvua.or.ke/index.php/what-we-do.

${ }^{137}$ Rafael Wanyonyi, interview by author, Kitale, June 2, 2014. According to Pastor Wanyonyi, most Global Mission workers abandon their work because they have become discouraged, due to unreliable payments from foreign sponsors. The uniqueness of nomadism and family ties are other reasons for abandoning work.

${ }^{138}$ Other projects sponsored by PMP include advocacy for long-term government involvement in Pokot, sponsoring students from poor families, conducting evangelistic campaigns, periodic community health education and free clinics, and the construction of the Kolowa SDA Church. For additional information on projects by PMP, see "About_Pokot Mission Project," accessed August 21, 2015, http://pokotmission.blogspot.com/p/about.html.
} 


\section{Construction of Churches}

In urban areas with more settled populations, especially among the agriculturists, churches have been constructed by various groups. These include Ginyang SDA, in North Pokot, that is sponsored by the Back to Africa group ${ }^{139}$ in conjunction with the University of East Africa-Baraton.

\section{Advocacy for Peace}

The Pokot territory is a region marred with hostility and warfare. Communities with differing cultural practices fight for cattle and compete for grazing land. Advocacy and the promotion of peace is another avenue through which Seventh-day Adventists address the needs of the people. Although this approach has not proven beneficial on a large scale, several initiatives to care for warfare victims, especially orphans and widows have been started. Initiatives by groups such as the Pokot-Turkana Peace Initiative include an orphanage at Kapedo, East Pokot, which takes care of children orphaned by tribal clashes or Human Immunodeficiency Virus (HIV) or Acquired Immune Deficiency Syndrome. ${ }^{140}$

\section{Summary}

The Pokot of East Africa are a well-established community with a history dating back to the eighteenth century migration and settlement of the African peoples. They are

139 The Back to Africa group is mostly composed of African American Seventh-day Adventists. In collaboration with others, they are engaged in missionary activities throughout most parts of Africa.

${ }^{140}$ For additional information, see "Pokot-Turkana Peace Initiative: Initial Findings and Recommendations,” Pokot-Turkana Peace Initiative, accessed November 11, 2016, http://www.pokot turkanapeaceinitiative.com/about.html. 
characterized by a complex socio-cultural heritage that remains the focus of anthropological investigation.

Christian mission among the Pokot continues to be a challenge. Various Christian groups are engaged in witnessing throughout the region, employing methods such as relief, health, education, Global Mission workers, and advocacy for peace. In spite of these approaches and efforts, the unique Pokot cultural heritage that distinguishes them from other groups and a lifestyle of constant movement continue to be barriers to effective witness. The next chapter presents an analysis of the Pokot worldview based on field research conducted in the summer of 2014. 


\section{CHAPTER 4}

\section{ETHNOGRAPHY OF THE POKOT:}

\section{RESEARCH FINDINGS}

\section{Introduction}

In the summer of 2014, I conducted qualitative research to collect data that better enabled me to: (1) describe the Pokot cultural worldview and (2) investigate challenges facing the growth and development of the SDA mission in Pokot. This chapter describes the research process and presents the analyses and findings.

\section{Qualitative Research Design}

Generally, deep, sensitive, delicate, and complex cultural worldview themes such as people's beliefs, values, and spirituality are better studied through a qualitative research method of inquiry. ${ }^{1}$ These critical concepts require an approach that ensures flexibility in research and the conducting of inquiry in a more natural setting, a fundamental environment for establishing a broad and well-rounded picture of the topic

\footnotetext{
${ }^{1}$ Elliston, Introduction to Missiological Research, 74; Jane Ritchie et al., Qualitative Research Practice: A Guide for Social Science Students and Researchers (New York: Sage, 2013), 103.
} 
of study. ${ }^{2}$ The Qualitative research also requires the use of various approaches such as ethnography, grounded theory, field research, and phenomenology when investigating particular topics in particular contexts ${ }^{3}$

Selecting an approach to employ is an important step in the qualitative research process. When considering an approach, the purpose of the research, the role of the researcher, and the method of data collection and analysis are of the utmost influence. ${ }^{4}$ It is recommended that broad and rigorous topics such as the shared cultural values of a group, which require greater time and patience, be studied through the ethnographic approach. This method was adopted to investigate the Pokot cultural worldview.

\section{Ethnographic Approach}

Ethnography is central, widely used, and the preferred approach for studying complex and broad culture-related topics. To investigate socio cultural patterns of communities, institutions, and other social settings, ethnography is suitable because it takes into account complex group behaviors by revealing interrelationships among

\footnotetext{
${ }^{2}$ John W. Creswell, Qualitative Inquiry and Research Design: Choosing among Five Approaches (Thousand Oaks, CA: Sage, 2013), 46. Creswell states that qualitative research should: (1) be conducted in a natural setting preferably the field where participants experience the issue under study; (2) rely on the researcher as a key instrument in data collection; (3) utilize multiple methods that are interactive and humanistic; (4) involve complex reasoning fluctuating between inductive and deductive; (5) focus on participants' perspectives, their meanings and their multiple subjective views; (6) situate the research within the context or setting of participants' social settings politically and historically; (7) involve an emergent and evolving design rather than a tightly prefigured design; (8) be reflective and interpretivesensitive to the researcher's biographies/social identity; and (9) present a holistic picture See also Margaret R. Roller and Paul J. Lavrakas, Applied Qualitative Research Design: A Total Quality Framework Approach (New York: The Guilford, 2015), 4-9.

${ }^{3}$ William Trochim, James P. Donnelly, and Kanika Arora, Research Methods: The Essential Knowledge Base (Boston, MA: Cengage, 2015), 60.

${ }^{4}$ Ibid.
} 
multifaceted dimensions of group interactions. ${ }^{5}$ It is easier to study an entire culturesharing group through ethnography rather than the interaction of a few individuals who share particular values that may differ from other community members. ${ }^{6}$

Explanation of context is an important component of ethnography. Understanding the reasons behind certain behaviors and events, what and why people do what they do, is a feature that enables researchers to make informed conclusions about lifestyle, practices, and belief systems rather than offering speculation. ${ }^{7}$ Ethnography also helps to reveal qualities of group experience, in addition to determining future questions and types of follow-up research.

The role of the researcher is key in ethnography. Functions of the researcher include the choice of a research site, sampling of the research participants, data collection, data analysis, and presentation of the findings. ${ }^{8}$ The researcher is also responsible for building positive rapport enabled by good relations with the community and adherence to research ethics. In order to enhance learning about a community and extract verifiable data, a researcher must also develop intimacy with the community through fully participating in daily activities such as eating local food, accepting invitations to social events, and being attentive to personal narratives. ${ }^{9}$ In addition to my

\footnotetext{
${ }^{5}$ Stephen L. Schensul, Jean J. Schensul, and Margaret Diane LeCompte, Essential Ethnographic Methods: Observations, Interviews, and Questionnaires (Lanham, MD: Altamira, 1999), 1.

${ }^{6}$ Creswell, Qualitative Inquiry, 90.

${ }^{7}$ Ibid.

${ }^{8}$ Harry F. Wolcott, Ethnography: A Way of Seeing (New York, Altamira, 2008), 54.

${ }^{9}$ Margaret Diane LeCompte and Jean J. Schensul, Designing and Conducting Ethnographic Research: An Introduction (Lanham, MD: AltaMira, 2010), 15.
} 
prior knowledge of the Pokot people, I spent two months among them holding conversations, conducting interviews, and participating in daily activities.

\section{Data Collection}

Various activities are conducted to collect data in ethnography. Participant observation, interviews, artifact examination, and casual dialogue are the methods most frequently used. The topic of study and context of the research determine the method for data collection.

\section{Participant Observation}

Participant observation is the most common and universally accepted field strategy for gathering data. ${ }^{10}$ It is described as the "hallmark" of both anthropological and sociological studies that systematically describes the events, behavior, and artifacts of a people under study. ${ }^{11}$ Through activities such as active looking and listening, memorizing, casual dialogue, and writing notes, participant observation enables a researcher to describe existing situations in a community.

The personal involvement of the researcher in the social setting is imperative since it allows one to experience the explicit and implicit reality of a people. ${ }^{12}$ This is made possible when the ethnographer gets deep into the culture, becoming an active

\footnotetext{
${ }^{10}$ Kathleen M. DeWalt and Billie R. DeWalt, Participant Observation: A Guide for Fieldworkers (Lanham, MD: AltaMira, 2011), 2.

${ }^{11}$ Barbara B. Kawulich, "Participant Observation as a Data Collection Method," Forum Qualitative Research 6, no. 2 (May 2005), accessed December 3, 2016, http://www.qualitativeresearch.net/index.php/fqs/article/view/466/996.

${ }^{12}$ Corrine Glesne, Becoming Qualitative Researchers: An Introduction (London, Longman, 1999).
} 
participant in community rituals, daily activities, interactions, and social events, while making observations and recording. ${ }^{13}$

\section{Interviewing}

Interviewing for data collection is described as "a conversation with purpose" where communication takes place "frankly and freely" while at the same time remaining focused and controlled so that the initial purpose of the interview is achieved. ${ }^{14}$

Interviews may be informal, standard, or general. ${ }^{15}$ In ethnography, interviews are mostly informal without predetermined responses, which allows a researcher to explore wider topics and uncover the participant's perspectives, an approach that is vital to understanding deep culture. ${ }^{16}$ Open-ended questions are usually pursued since they tend to permit participation and to elicit additional information from the participants.

\section{Artifact Examination}

Artifacts are things that people make or do. A community's artifacts represent beliefs, values, and meaning, through which a culture is produced, used, or modified. ${ }^{17}$ Since researchers are challenged not to assume the meaning of artifacts, which may be

${ }^{13}$ DeWalt and DeWalt, Participant Observation, 1-2.

${ }^{14}$ Robert Louis Kahn and Charles F. Cannell, The Dynamics of Interviewing: Theory, Technique, and Cases (DeKalb, IL: John Wiley, 1957), 97.

${ }^{15}$ Michael Quinn Patton, Qualitative Research \& Evaluation Methods (Thousand Oaks, CA: Sage, 2002), 341-347. 2015), 125.

${ }^{16}$ Carolyn Babione, Practitioner Teacher Inquiry and Research (San Francisco, CA: Jossey-Bass,

${ }^{17}$ Julian Murchison, Ethnography Essentials: Designing, Conducting, and Presenting Your Research (San Francisco, CA: Jossey-Bass, 2015), 164. 
created for different reasons than the researcher expects, involving an informant to guide artifact analysis is essential. ${ }^{18}$

\section{Casual Dialogue}

In spite of its "aimless appearance" and "apparent trivial content," casual conversation is a highly structured functional activity that establishes who people are, their relation with the environment and fellow humans, and what they think of the world ${ }^{19}$ Valuable information that enhances a study can be gathered through casual conversation with community members. ${ }^{20}$ Positive rapport and interesting topics of conversation are necessary ingredients to attain the dialogues, which are necessary for gathering data.

\section{Purposeful Sampling}

Selection of a subset of a population to participate in research on behalf of the whole group is a primary step in qualitative research. Preselected criteria determine the selection process and guide the number of participants, based on the nature of study. ${ }^{21}$ One of the fundamental requirements for participation is having an in-depth knowledge

${ }^{18}$ Murchison, Ethnography Essentials.

${ }^{19}$ Nicole Müller and Martin J. Ball, eds., Analyzing Casual Conversation (New York: Wiley and Sons, 2013), 6.

${ }^{20}$ Manohar S. Pawar, Data Collecting Methods and Experiences: A Guide for Social Researchers (Elgin, IL: New Dawn, 2004), 164.

${ }^{21}$ Emily Adler and Roger Clark, How It Is Done: An Invitation to Social Research (Belmont, CA: Thompson Learning, 2008), 121-123. Other types of sampling include quota sampling, snowball sampling, and convenient sampling. 
of the topic being investigated. ${ }^{22}$ In ethnographic research, the availability of willing participants in an uncontrolled environment plays a major role in data collection.

\section{Ethical Considerations}

Adherence to ethical standards when conducting research that involves humans is fundamental. The Belmont Report spells out research guidelines for situations in which human beings are subjects. These guidelines include the respect of persons, justice, and beneficence, evidenced by the signing of informed consents. ${ }^{23}$ In accordance with these standards, which were amplified and stipulated by the Andrews University Institutional Review Board, ${ }^{24}$ the interview venues in this study were of the participant's choice and ensured the interviewee's privacy and comfort. The collected data in notebooks and videotapes were securely locked and were accessible only to me.

\section{Transcription and Analysis}

The process of transcription and analysis typically begins while in the field and continues throughout the research process until presentation. ${ }^{25}$ Obtained data were categorized according to the three cultural worldview dimensions - cognitive, evaluative,

\footnotetext{
${ }^{22}$ Marguerite G. Lodico, Dean T. Spaulding, and Katherine H. Voegtle, Methods in Educational Research: From Theory to Practice (San Francisco, CA: Jossey-Bass, 2010), 101.

${ }^{23}$ For more information on research standards, see U.S. Department of Health and Human Services, "The Belmont Report," accessed September 2, 2016, http://www.hhs.gov/ohrp/regulations-andpolicy/belmont-report/.

${ }^{24}$ The Andrews University Institutional Review Board makes certain that research involving human subjects is conducted under ethical and scientific principles that ensures participants' rights and welfare, and that recruitment to participate in research is free of coercion and safeguarded. For more information, see "Research Integrity and Compliance," accessed May 11, 2014, http://www.andrews.edu /services/research/research_compliance/.

${ }^{25}$ Margaret Diane LeCompte and Jean J. Schensul, Analysis and Interpretation of Ethnographic Data: A Mixed Methods Approach (Plymouth, UK: AltaMira, 2013), 27.
} 
and affective dimensions ${ }^{26}$ (see Table 1). The cognitive dimension revealed various conceptual assumptions, which the Pokot use to define and explain the nature of reality. They included concepts of origins, time, space, destiny, individuality, community, and causality.

\section{Table 1. Worldview dimensions and themes}

\begin{tabular}{lll}
\hline Cognitive Themes & Affective Themes & Evaluative Themes \\
\hline Origins & Forms of Expression & Moral standards \\
Time & Central story/message & Heroes and heroines \\
Space & Worship, awe, music, & Standards, manners \\
Destiny & expressions & Respect \\
Individual/group/others & Feelings, guilt, spirits & Trust \\
\hline
\end{tabular}

In the evaluative dimension, Pokot assumptions regarding moral standards, virtues, manners, and social order were explored. Rules, taboos, and expectations serve as criterion determinant of what is right and wrong, true and false, and also what is likable and what is unlikable. On the other hand, heroism, generosity, bravery, virginity, trust, respect, and wealth are emphasized as virtues to be emulated. The affective dimension describes deep feelings such as joy, anger, sorrow, fear, awe, worship, and other expressions. Among the Pokot, these emotions were displayed mostly during musical dances, funerals, and community celebrations.

Data collected were analyzed using the Content Analysis Method. ${ }^{27}$ This approach is suitable when analyzing data in a narrative form and is collected using

\footnotetext{
${ }^{26}$ Kraft, Anthropology for Christian, 63-65; Hiebert, Transforming Worldviews, 57-60.

${ }^{27}$ Margrit Schreier, Qualitative Content Analysis in Practice (Washington, DC: Sage, 2012).
} 
interviews, focus groups, and participant observation. Content analysis categorizes verbal and behavioral data for the purpose of summarization and tabulation in order to highlight vital and central themes.

\section{Data Collection Procedures}

The first part of the research involved interviews with elders from the Kapenguria market center and the villages of Sigor and Chepararia in West Pokot County. These sites are approximately 50 kilometers apart, more central and secure, and research participants were more readily available here than at other locations.

\section{Oral Interviews (Part 1)}

Oral interviews with three separate focus groups of Pokot elders were conducted. The focus groups were each composed of five Pokot male elders of fifty years and older since they are the depositories of the pooled knowledge of the Pokot culture. An interview protocol generated from the literature explaining the composition of cultural worldview themes was used. In order to obtain clarity of information, follow-up questions and casual dialogue with people and the key informants were also considered part of the data collection strategy.

\section{Artifact Examination}

Cultural artifact items such as walking sticks for the elderly, food containers, herding sticks for warriors, morans, and "pillow chairs" were examined. These items harbor deep cultural values and meanings and are significant to Pokot daily living. Other research activities included observation of open-air market activities and participation in amuro, a cultural send-off ceremony organized for me by the Sigor village members. 


\section{Cognitive Themes}

As previously discussed, the cognitive dimension of worldview describe mental concepts held by a people concerning themes such as origins, time, space, self and others, and causality. ${ }^{28}$ Understanding these concepts helps one communicate the gospel more effectively by because barriers and bridges that exist in new territories can be more easily identified. $^{29}$

\section{Origins}

Differing opinions about Pokot origins exist. In Sigor, interview participants pointed to the adjacent Cherengani hills as the original home of their ancestors who migrated to different settlements in the past, including the present locations. In Chepararia village, one elder, Olukoi, stated that since the Pokot people are closely related to their neighbors, the Kalenjin groups, who also originated from Egypt and Sudan along the Nile River, they too consider Sudan as their original homeland. He argued that the Pokot migrated along with other tribes from the Khartoum area because this name is translated "the river that blocks" in the Pokot language. He explained that Khartoum referred to the time when during floods along the River Nile, the Pokot and other tribes were prevented from advancing in their migration expansions.

One interviewee in Sigor, Lorube, responded that the Pokot have no single ancestral descent but are instead an amalgamation of people from various Kalenjin ethnic backgrounds. He mentioned that the Pokot are cousins with the Turkana, the Tugen, the

${ }^{28}$ Hiebert, Transforming Worldviews, 50-59.

${ }^{29}$ Scott A. Moreau, Evvy Hay Campbell, and Susan Greener, Effective Intercultural Communication (Encountering Mission): A Christian Perspective (Grand Rapids, MI: Baker Books, 2014), 64-65. 
Samburu, and other Nandi speaking tribes. They must have come from the same ancestors since they share similar cultural values and practices. The rest of the group agreed with him that Kalenjin groups descended from northern Kenya, the direction of their neighbors and sworn enemies, the Turkana people. The group also noted that common sociocultural practices such as circumcision, female genital mutilation, and tattooing of animals among the pastoral groups signify a common ancestry. According to Lopetakou, the theory of shared ancestry explains why some Pokot people trace their roots to the various clans of groups such as the Tugen, Keiyo, Marakwet, Nandi, Sebei, Njemps, Samburu, Turkana, and Karamojong peoples.

Various reasons for the Pokot migration from their original home or separation from other groups were given. These were categorized as either internal or external, economic or political, social or adventurous. Lemokel cited the search for land for expansion and for pastures for animals as the outstanding economic reasons for migration. He also noted that politically, wars with other communities because of land disputes played a key role for moving. Other interview participants unanimously named disease, adventure, and drought as socioeconomic reasons that prompted the Pokot to migrate to new settlements.

Migration to new places is still prevalent among the Pokot. During a casual tour in Sigor with an informant, abandoned homesteads from where some clans had recently moved were observed. The informant stated that rain had been rare in the area for several months and this had caused animals to die and forced some people to move to distant lands.

The different opinions expressed concerning Pokot origins and their migration experience have previously existed. Most of the responses obtained from the interviews 
were consistent with existing oral and written historical accounts discussed in the previous chapter. $^{30}$

\section{Time}

The Pokot understanding of time can be described as cyclical. Past occurrences, seasons, and actions have tremendous implications for life in the present and in the future. The elders spend considerable time narrating past events and stories on various subjects, such as origins, wars, and calamities. These are intended to teach values of generosity, respect, kindness, and trust and to promote virtuous living among the younger generation.

Birthdays are remembered based on seasons or significant events of the past.

When asked about the year they were born, most participants referred to past events such as floods, hunger, drought, or disease as the time when they were born. One elderly man recalled that when they moved to the village in Sigor, he was "just a little boy" when the Turkana raided their village and took their animals. For the elderly, the exact year did not matter- the event told time.

The four-year period of 1878-1882 is still considered one of the harshest moments in Pokot history. During that time, a great famine killed nearly all of the livestock except a few goats, an outbreak of smallpox killed large numbers of Pokot people, and humanlike man-eater lions and other wild animals attacked, killing most of the remaining Pokot during that era. Drawings of these fearsome animals were shown by Lopetakou during the interview. The period is significant because the Pokot people were nearly wiped out

\footnotetext{
${ }^{30}$ Jónsson, "Pokot Masculinity,” 25; Bollig, Risk Management, 22.
} 
and drastically reduced in number. Kapenguria village elder, Mariamoi, stated that it is widely known that the few people who survived the 1878-1882 tragedies sought shelter among other Kalenjin groups.

Other important periods mentioned were the three-year famine and Rinderpest outbreak of 1905-1908 and the cerebral spinal meningitis epidemic of 1917. These two eras are remembered, second to tragedies of 1900s, as periods when there was a great loss of life.

The coming of the Europeans in the twentieth century is a memorable event in Pokot history and a major historical moment in Pokot socioeconomic existence. Apart from losing independence in most areas of life, the Pokot people lost property. One aged man vividly recalled the forceful eviction of the Pokot by white settlers from their fertile land of northern Trans-Nzoia in the early part of that century. He stated that the Pokot were pushed out to less fertile regions along the Kenya-Uganda border, which are marked by less rain and poor soils for cultivation. According to him, these bitter memories have been the cause of the Pokot skepticism toward outsiders who many believe harbor ulterior motives.

The Pokot like, most tribal communities, value events more than the keeping of time. This was manifested perfectly at the research sites when research participants expressed no hurry coming to the interview site or leaving at the end of the sessions. They hovered around the interview centers exchanging casual conversations with other community members who were curious to know what was taking place.

When asked what time of day it was, respondents of the Chepararia interview group unanimously gazed at the sky to find the position of the sun since this is the common way of telling time. Wearing of watches is rare or nonexistent. No one was 
observed to have a watch for telling time. It was also observed that people generally spend time socializing in market places without any sense of urgency. Men were observed roaming in villages and public centers dialoging while the women relaxed in groups sharing conversations under the shade of trees or houses.

\section{Space}

There are ordinary places where people live and carry on daily activities and there are holy places, which are dwellings of divine beings and the spirits of ancestors. Among the sacred places are Mt. Mtelo in Uganda, which is considered the seat of God, from which Tororot reigns, uttering blessings and curses. During periods of calamity, such as unfamiliar diseases, prolonged drought, and war, people seek and receive answers and instructions by offering animal sacrifices and rituals at the mountain. Deliverance and protection against destruction from one's enemies or spirits is achieved through similar processes. Other places considered habitations for divine beings and therefore sacred are caves, river banks, thick forests, and certain trees.

For instance, Loroupe, one of the Sigor village clan elders, noted that prevalent Pokot mythology indicates that there is a tree on Mt. Mtelo that cures cholera, typhoid, and other diseases. To obtain directions and instructions on how to cure such diseases, traditional religious ceremonies are held while facing the mountain. Religious leaders who are responsible for instructing the community on religious matters give special procedures and precautions, which include what and what not to touch, disposal of sacrificial carcasses, and positions to be assumed by the worshippers. Other activities carried out at the mountain include the conducting of rituals and ceremonies in honor of 
the divine by individuals or by a whole clan when favors such as rain, victory at war, and healing occurs.

Mt. Kadem in Uganda is another sacred place for the Pokot. Spirits of ancestors are believed to inhabit the mountain as well as a particular type of tree, keipkoyoy, which is considered a biological weapon. Only selected religious personnel are allowed to handle the tree since its leaves are believed to possess healing as well as destructive powers. The most senior elders from the three villages stated that when burned, smoke from the leaves of the keipkoyoy tree can destroy everything that comes in its way. The elders added that no birds land on the tree and no other trees grow close to the keipkoyoy, a sign of the tree's dangerous and divine powers.

\section{Destiny}

The Pokot believe in life after death. Deceased elderly people are assumed to exist among the living in a spirit form. As a result, respect and adoration of the "living dead" (ancestors) is strongly held among the Pokot. Olukavi, an aged woman, said, "This belief is the very reason why special rituals and ceremonies are conducted during and after a burial to honor and 'bring home' the spirit of departed family members." In a casual dialogue with an informant, it was stated that these ceremonies are not conducted for younger people who die in the field grazing animals. The young morans (warriors) who die in the field are often abandoned in the wilderness for wild animals to consume their remains, even though the practice is declining in modern times.

Among the practices for honoring the living dead is the serving of food at the gravesite. On one homestead, food containers around the edge of a grave were observed. The informant stated that usually foods, which the deceased people liked when they were 
alive, are served in special cultural containers (see Figure 2). These remain overnight for the deceased spirit to consume. In the morning, the food containers will be found empty, indicating that the deceased consumed the food.

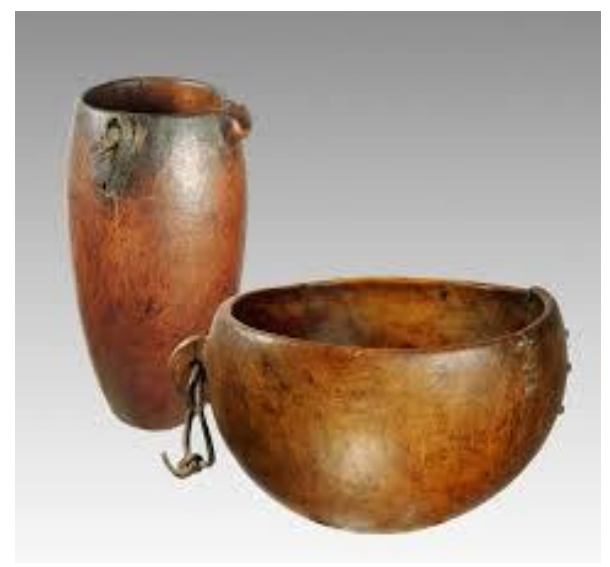

Figure 2. Pokot Milk Pail and Food Bowl. The Pokot milk pail and food bowl are used for children as well as for men out in the field grazing animals. These same dishes are used for serving food to the ancestral spirits. The size of the milk pail or food bowl is dependent on the age and role of the family member. Men's containers are usually larger.

Dishonoring the dead is a taboo among the Pokot. Dishonoring may include not serving food, not conducting rituals to appease the spirits, or allowing children to play on or around the grave. Such neglect may result in angering the dead, which leads to attacks from the spirits in the form of disease, hunger, drought, warnings from evil birds such as the owl, theft of animals, or other calamities. During situations of disaster resulting from dishonoring the living dead, and to avoid future occurrences, rituals are recommended.

The living dead (ancestors) play a significant role among the living. They are believed to be mediators between the living and divine beings, showering the community with blessings believed to communicate warnings through calamities and destruction when the community's and poghishyo (peace and harmony) if laws and regulations are 
obeyed. They are also poghishyo is endangered by disobeying societal order. One elderly man, Mariamoi, mentioned that ancestors are part of the family. They instruct, warn, bless, and offer direction. Children are named after those ancestors with good moral reputations or those who contributed to the community's survival during war or calamity, wooing them to emulate these figures.

\section{Individual/Group/Others}

Among the Pokot, communal life is more highly valued than individual existence. Life and thought are centered on the group rather than on the individual or things. Every member of the community is expected to demonstrate loyalty and respect to their parents, older siblings, elders, age mates and friends. Respect for the elders' authority is paramount and unquestionable. It was unanimously agreed upon among the respondents that groups offer mutual support and strength during times of need. They stated that a person living alone cannot survive. Groups also offer a sense of belonging and a respect for relationship. At Sigor, a moran (warrior), who was allowed to speak interjected, "When people live together communally and agree on tasks and rules to be followed, it guarantees cooperation and strength to the society." Generally, individuals are only respected for their contributions to the group rather than for their individual accomplishments. Close trust and reliance on others is also emphasized.

The value of community was also noted in acts of sharing. At Sigor, young men were observed delivering meat to various homesteads. This had had been slaughtered by elders from a neighboring village who and had the urge to share with their neighbors. The informant stated that such a practice is common and widely encouraged. Sharing is also common during cerebrations such as birth, circumcision, sapana, marriage, and death. 
During these occasions, an invitation is unnecessary since everyone is expected to attend or support the event in some way.

\section{Evaluative Themes}

The evaluative dimension describe the moral code, virtues, and societal order of a group. ${ }^{31}$ Standards for upright living, such as heroism, generosity, respect, and trust, bravery, wealth, and versatility are embedded under the evaluative assumptions of worldview. ${ }^{32}$

\section{Pokot Heroes/Heroines}

Various Pokot and non-Pokot people are revered as heroes and heroines. These individuals serve as models whom every community member, particularly the youth, are expected to emulate. Distinguished leadership qualities, selflessness living, bravery, heroic acts, and other valued contributions to the survival and existence of the Pokot people are factors that characterize heroism. Most of these figures exhibited heroism in the past or in the present and are therefore respected for enabling continuity of the community in challenging times.

Pokot heroes were categorized as spiritual, political, or religious leaders. They served during various historical times such as the pre-colonial, colonial, or post-colonial era. The spiritual leaders, diviners, seers, prophets, and chief advisors were pre-colonial heroes. They are still considered heroes in the present time since they mediate between the people and the divine. Through direct communication with the divine, spiritual

\footnotetext{
${ }^{31}$ Hiebert, Transforming, 60-64.

${ }^{32}$ Ibid.
} 
leaders provide the Pokot with instructions on daily living so as to prevent displeasing Tororot and therefore avoid calamity. It is widely assumed that Tororot's will is communicated through these leaders.

Parma and his son Mariamoi, who led the highland Pokots, are honored as spiritual leaders. They heroically led the Pokot during periods of war against neighboring groups. Apart from offering direct attacks against the enemy, they are said to have also presided over religious rituals, which culminated in successful warfare. After Parma's death before colonial era, his son Mariamoi continues the legacy of his father.

The pastoralists also recognize Tamatachom, Arimot, and Apalodir, who lived in Trans-Nzoia before the eviction of 1916-1920. Tamatachom was a military as well as a spiritual leader for the North Pokot. His counterpart in Uganda, Arimot, ruled during the same era. His son Arimot, who led the pastoralists in Trans Nzoia until the eviction of 1916-1920, succeeded Tamatachom. Strong leadership qualities were also displayed among the East Pokot. Ptura and his son Lomomuk are remembered for leading the group during challenging moments and thereby contributing to their survival.

Other respected leaders include the medicine people, especially women. The role of women in child care has consciously given them tremendous experience in diagnosing disease and identifying herbs for curing various illnesses. Others are cow-healers, who detect and prescribe herbs to treat cattle diseases. In every village, presumably, a cowhealer offer services as a free-will contribution to the community's well-being. Lopetakou stated that in order for the colonialists to control the Pokot, most of these spiritual leaders and healers were exiled as a strategy of weakening the Pokot to pave the way for colonialism. 
The council of elders, kokwo, was named as an important leadership institution in Pokot throughout the years. In spite of leadership transitions in post-independence Kenya, kokwo continues to remain an important informal crisis-solving institution among the Pokot. Kokwo's composition of experienced aged men that are endowed with wisdom and historical information, guarantees that justice consistent with the community's value and belief system is served.

Other Pokot heroes remembered to date surprisingly include the second British District Commissioner, Crampton, who governed between 1918 and 1920. It was during Crampton's period of influence that the Pokot lost large numbers of livestock to the Turkana, who frequently raided their neighbors. After one of the attacks, Crampton led a military operation against the well-armed Turkana to disarm them because of the frequent raids they waged against the Pokot. He successfully managed to restore stolen animals back to the Pokot, and peace prevailed in the region. During the interview, Lotodo, one of the village elders retorted that no military operation like that of Crampton has been witnessed in the region. It was also noted that since the time of Crampton, the Pokot have not experienced large-scale livestock loss to rustlers. Tonoi, a Kapenguria village elder said, "The Crampton's legacy of still reigns and is a hero for us."

The local chiefs who served during the colonial and post-colonial era are also respected because of their ability to maintain law and order. Among them is Lokuk Atachalee. He is remembered as the only Pokot chief whom the white colonialists would salute. His British royal uniform that contained a royal crown required everyone, including the colonialists, to salute him not because he was a chief but because he wore the crown. In East Pokot, another chief, Komol Kaper, is revered as a strong leader who defied colonial authority. When colonialists sought to improve the quality of Pokot 
livestock by reducing their numbers through vaccinations and other treatments, Komol Kaper rejected the proposal. His people, who held no trust of the intruders, believed that the chief helped to protect the community against insidious moves by the colonialists to eliminate the Pokot livestock and therefore prevented the outsiders from advancing their agenda in Pokot land.

\section{Generosity}

The character trait of generosity is highly valued and promoted among the Pokot. Each member of the community is expected to offer their property, time, and effort for the benefit of others. Sharing and helpfulness are considered most important for good community citizenship. On route to Sigor village, a group of elderly men was observed slaughtering a cow donated by a member of the village. After a few minutes, young men went around the village making delivery of the meat. The informant stated that sharing meat is common, especially during dry seasons when crops are scarce.

Similarly, families with more cattle are expected to give to those with less. In a casual conversation with one elder, it was stated that "people should be willing to share rather than work to get ahead or save for the future." Helping the community is valued above individual ambition.

In Sigor, elders lamented that Western education had robbed the community of its younger people who are responsible for grazing cattle. It was stated that because of the individual pursuits that are emphasized in Western education, most morans (warriors), who are depended on for protection and development, had left the community for cities and rarely came back to offer support. 


\section{Respect and Trust}

Respect for the elderly people is an obligation of all Pokot. It is believed that wisdom comes with age, and therefore, senior members of the community deserve absolute respect from the younger generation. It is a taboo for young people to talk while in the company of older people unless allowed to so. There are also special places at home and in public reserved for elderly people to sit. Community members are expected to observe their position and role in the social ladder. One elder pointed to a walking stick (see Figure 3) stating that if the stick is pointed to a young person, it serves as a warning for impending discipline or as a prediction of a troubled future for an individual without respect or moral character.

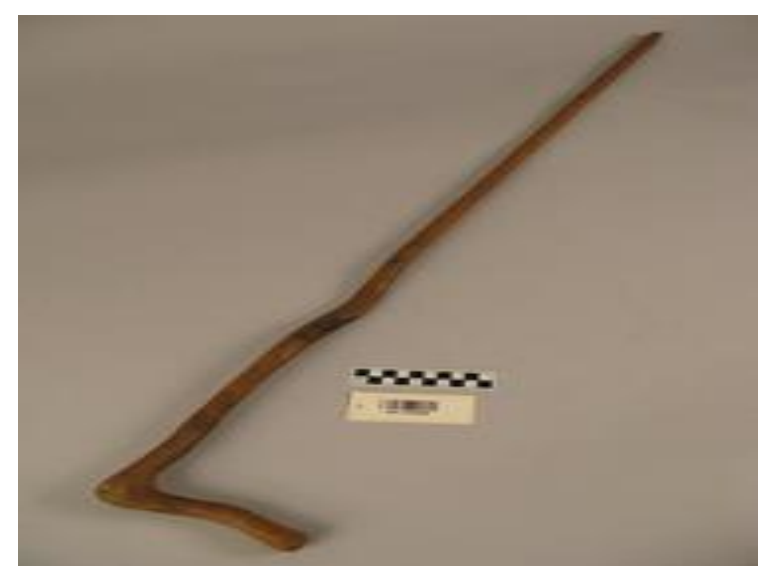

Figure 3. Pokot walking and defense stick. The walking stick is mostly for elderly men. When young people go against community morals and regulations, elders point at them with this stick as a sign of disappointment.

Personal relationships among other community members are also based on mutual respect. Care not to be disrespectful toward others is observed disrespect may cause calamity from angering tororot (god) and break poghishyo (peace and harmony) in the community. During a tour of one village homestead, it was stated that because respect 
and trust are valued, a moran (warrior) can spend the night at another moran's house, even in the absence of the host moran without the suspicion. Respect of hierarchy and authority is required indiscriminately. Family and public authority is obeyed with dire consequences if not followed.

\section{Bravery}

Bravery is a virtue instilled and expected of all men. From childhood, young boys are groomed to be brave because the community's security and survival against fierce and aggressive neighbors is dependent on brave men. In order to achieve and instill bravery, boys undergo various initiation rites throughout their lifetimes. These rituals and celebrations, which include circumcision and sapana, also serve as a test for bravery before one is entrusted with a role.

During the administration of initiation rites, interviewees from all three focus groups agreed that boys cannot flinch. The ritual of circumcision requires one undergoing the practice to be brave without displaying any jot of fear or pain, a test for one entering moranhood (warrior hood). When asked what would happen to one who flinched, the informant stated that the individual who displays fear may suffer loss of respect among age-mates, face punishment through beatings and public shaming, or lose status and role in the community. These penalties serve as a warning to others.

Bravery is highly displayed when defending the community against attacks from enemies or cattle rustlers. Morans were observed spending their nights out in the field with animals. The informant stated that they are expected to keep wild animals away from livestock and human habitations. At the Sigor interview, five morans had come from the field to collect food for their group which had been away in the field looking 
after livestock for over a month. Although bravery is expected of all members, it is more expected of men than the women.

\section{Wealth}

The Pokot desire to obtain and possess wealth. For the most part, the number of livestock (mostly cows) an individual owns measures an individual's wealth. Cows are valued for two main reasons: (1) for their products (milk, meat, and skin), which are essentials for survival, and (2) as a bride price. In a region severely limited in agricultural production, livestock products are the only means of survival for the community. The informant who hails from the region stated that "death of cows means death of people."

Men with many cows are considered rich and are, therefore, highly favored for various privileges and societal positions. These include accessibility to leadership roles because they are considered responsible and productive people who can care for their families and, thus, a whole community. Lopetakou, an elder from Kapenguria, stated that having many cows is "the chief reason why men with many cows are polygamous." Such men are able to pay the bride price, and, therefore, most families do not mind giving their daughters to such men in marriage since they are likely to fetch wealth for the family.

To be without livestock is considered a shame and curse. Leguk, an elder from Chepararia, said that no man is admissible to speak in public if he has no cows. "Such people have no future," he reiterated. Lopetakou clarified a widely-held notion that the Pokot worship cows. He stated that livestock are generally valued as a symbol of favor from Tororot to the people to guarantee prosperity. "Had they been objects of worship, we could not sacrifice them because they are holy," Lopetakou concluded. 


\section{Versatility}

Adaptability is a valued trait among the Pokot. A casual conversation with the informant revealed that with limited sources of food due to extreme climate, the Pokot have unconsciously adjusted themselves to survive in various ways. Lomomuk stated that most families eat once a day in the evening because of insufficient food. He noted that only young children eat twice a day when food is available. Even in cases when food is available, people are encouraged to continue being frugal in preparation for difficult times.

Consequently, most people spend their time during the day under the shades of large trees because of high temperatures in the region. Men have adjusted to a simple mobile life which enables them to walk around with their akicholong, pillow chair (see Figure 4). This assistive device is conveniently used for sitting when elders meet or rest in the shade in public, or as a pillow for the head when napping during a hot day. Herdsmen were also observed carrying their pillow chairs wherever they travel.

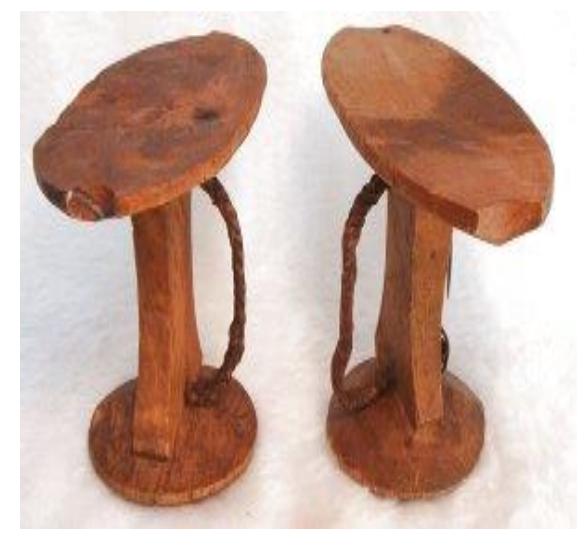

Figure 4. The Pokot Pillow Chair. The pillow chair, akicholong, ranges in color and shape. They are carved from a single piece of wood and have a leather handle attached for easy carrying. 
Other adaptive devices include the non-bent stick (see Figure 5). The non-bent stick is used by young men to tame cattle while grazing, engage in stick fighting ceremonies to choose a future marriage partner, or to kill wild animals like snakes. Most men carry these survival devices and use them to execute their grazing duties more conveniently.

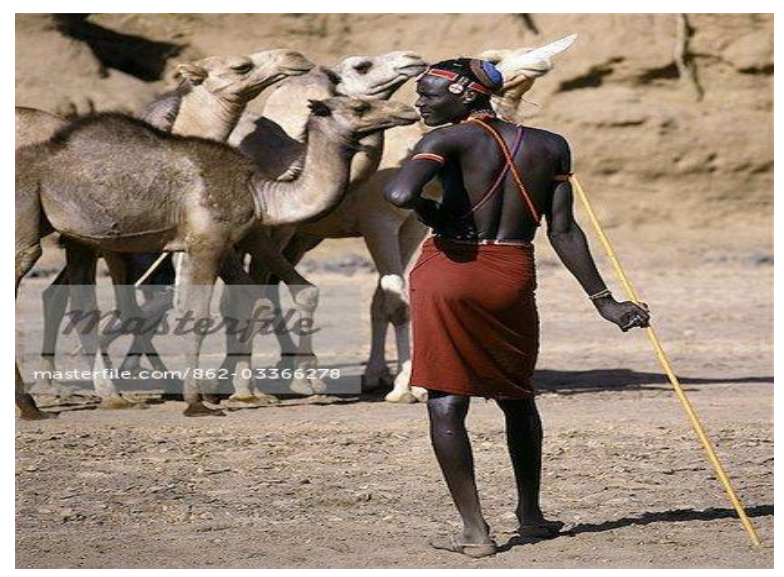

Figure 5. The Pokot non-bent stick

\section{Premarital Purity}

Premarital sexual relationships are a taboo in Pokot. The three focus groups were unanimous in their agreement that boys and girls are expected to be free of any intimate relations until marriage takes place. The informant stated that girls who remain virgins until marriage fetch more cows as a bride price for their parents compared to girls who bear children before marriage.

Parklea of Kapenguria stated that measures to protect pre-marital purity are in place throughout all of the Pokot clans. He named FGM as one important measure to 
minimize sexual desire in younger girls until marriage takes place. The other measure is imposition of heavy fines against boys involved in sexual activities before marriage.

\section{Affective Themes}

The affective dimension focuses on the emotional and expressive aspect of a people's culture. ${ }^{33}$ It encompasses aspects of fear, charisma in religious services, and social interactions through stories, proverbs, songs, dances, and riddles.

\section{Expressive Culture}

The Pokot are generally expressive in various aspects of life. Charisma in religious services is normal and flows naturally from individuals. Singing, dancing, chanting, jumping, and other forms of expressive passion during ceremonies were noted. Prayers in the form of songs are offered, entreating divine intervention for the protection of livestock and people, for more healthy calves to be born, and for enemies and wild animals to be kept away from the land.

One of the songs sung to welcome me and the research informant to Sigor village was a call to Tororot (god) to keep wild animals and rustlers away from attacking the cattle, to provide rain in due time, and to defend the people against disease and tragedy. The presenters, who were dressed in colorful garments, jumped, danced, and shook bangles around their necks and wrists. Well-coordinated dance moves were witnessed in various ceremonies including amuro, the send-off ceremony.

During celebrations and other community events, every member is expected to participate in singing and dancing as a sign of mutual solidarity and appreciation of

\footnotetext{
${ }^{33}$ Hiebert, Transforming Worldviews, 59-60.
} 
community. These songs are mostly learnt from childhood as they are often used to educate the youth community values.

\section{Fear of Spirits}

Fear of the spirits is characteristic of the Pokot culture. Casual conversations with the community members revealed that fear of and guilt from angering divine beings and spirits dominate the daily life of the Pokot people. Keen attention is paid not to anger these divine beings lest people suffer calamities of various nature and magnitude. Kaparmoi said that offenses like stealing cattle or other items from a fellow Pokot, premarital pregnancy, disobedience, insult and abuse of the elderly, and moral offenses are highly abominable because this angers the spirits and destroys poghishyo (peace) within the society.

In order to appease displeased spirits, offenders conduct rituals and ceremonies, be they individuals or the community as a whole. It was mentioned by Lopetakou that often people travel to Mount Kadem in Uganda, where spirits are said in inhabit, to offer sacrifices and conduct cleansing rituals. This follows incidents of disease breakdown, unexpected death in the family, or crop failure, which are signals of unpleased spirits.

Apart from divine spirits, the fear of ancestral spirits is also significant. It is believed that ancestral spirits play a significant role in the lives of the living. It was mentioned that spirits of the dead provide guidance on various issues within families because the dead are constantly watching over the living and their spirits are the messengers. It is widely believed that unpleased spirits of the dead cause disasters in the form of disease and unexplained misfortunes such as sudden death. These spirits too 
require animal sacrifice, religious ceremonies, and rituals to appease them in order to escape curses and spells from displeased ancestors.

\section{Orality}

Oral tradition is fundamental to the Pokot community. The value of stories, riddles, dances, songs, and proverbs to communicate messages cannot be underestimated. Transmission of information orally is viewed as a social process that reinforces interpersonal as well as intergenerational relationships. Young people learn important life lessons by listening to frequently narrated thought-provoking stores, proverbs, or riddles. Oral methods are also used to rebuke offenders, teach moral values, and challenge mental capabilities in young people. Lopetakou mentioned that Proverbs riddles, and sayings are often quoted by elders in community meetings as an indication of wisdom and leadership qualities.

Lopetaou's sentiments were affirmed by the informant who stated that clan elders apply proverbs extensively to rebuke, to shame, and discourage bad behaviors, or to warn young people from straying away from moral paths. They are skillfully quoted publicly during the elders' council, kokwo, as a sign of eloquence and oratory when deliberating and settling disputes. Many of the proverbs use livestock as a symbol to emphasize and illustrate values to be emulated.

Concerning stories, William Lopetakou said that stories are narrated at family circles, in the field during celebrations and rituals of rites of passage, or when tending animals. He noted that elderly men or women are usually the primary story-tellers. They use illustrations from nature to capture the attention and imagination of young listeners. 
Most ceremonies and rituals are never fulfilling unless accompanied with songs and dances. Like proverbs and stories, songs convey lessons and instructions for daily living as well as petitioning divine beings for protection, providence, and leadership.

Riddles are mostly applied by a storyteller to children to sharpen their thinking and imagination. Children use riddles among themselves when looking after animals or playing at home.

Chanting during rituals and ceremonies is also a form of communicating with the ancestors. During amuro, the send-off ceremony, the village elder repeatedly chanted, "May he have a blessing to finish his school. May his family be blessed too. May he be healthy and have safety return home and help his people." The villagers retorted back in unison saying “Anaam” (Let it be so). The importance of orality was observable when during the interviews, members requested one of them to sign on behalf of the group or use their thumb prints as a sign of approval to participate in the research. Table 2 provides a summary of these worldview assumptions.

\section{Oral Interviews (Part 2)}

In addition to the previous data collection activities, three oral interviews involving the Western Kenya Union evangelism director (Paul Girimbe), a district pastor, (Rafael Wanyonyi), and the first and long-time serving elder, (Joseph Parklea). The purpose of this part of the research was to establish growth trends and ministry challenges the SDA Church faces in its effort to reach the Pokot. This section presents the protocol that was used to guide the interviews and the findings of the second phase of the research. 


\section{Table 2. Summary of Pokot worldview themes}

\begin{tabular}{|c|c|c|}
\hline Worldview Theme & Pokot Concepts & Summary \\
\hline Origins & $\begin{array}{l}\text { South Sudan, Ethiopian } \\
\text { highlands, Cherengani } \\
\text { hills, Kalenjin groups }\end{array}$ & $\begin{array}{l}\text { Various theories of } \\
\text { origins are generally held. }\end{array}$ \\
\hline Causation & $\begin{array}{l}\text { Tororot (god), ancestral } \\
\text { spirits, demons, } \\
\text { witchcraft }\end{array}$ & $\begin{array}{l}\text { Sickness, death, } \\
\text { unhealthy animals }\end{array}$ \\
\hline Values & $\begin{array}{l}\text { Livestock, family } \\
\text { heroes/heroines, respect, } \\
\text { bravery, generosity }\end{array}$ & $\begin{array}{l}\text { Cows are a sign of wealth } \\
\text { which give owners a } \\
\text { distinguished status. }\end{array}$ \\
\hline Knowledge & $\begin{array}{l}\text { Gained through stories, } \\
\text { riddles, songs, dances, } \\
\text { drama, proverbs, artifacts }\end{array}$ & $\begin{array}{l}\text { Community values and } \\
\text { preservation of history are } \\
\text { through oral means. }\end{array}$ \\
\hline Success & $\begin{array}{l}\text { Many cattle, large family, } \\
\text { absence of disease and } \\
\text { drought, having enough } \\
\text { food }\end{array}$ & $\begin{array}{l}\text { Success is based on what } \\
\text { one possesses or the } \\
\text { absence of drought and } \\
\text { sickness. }\end{array}$ \\
\hline Relation to others & $\begin{array}{l}\text { Skeptical of outsiders, } \\
\text { friendly, generous, kind } \\
\text { to visitors, harsh and } \\
\text { ruthless to cattle rustlers }\end{array}$ & $\begin{array}{l}\text { Causes of skepticism } \\
\text { include experiences of } \\
\text { colonialism, evictions, } \\
\text { marginalization, raids } \\
\text { from neighbors, and } \\
\text { modern efforts to settle } \\
\text { pastoralists. }\end{array}$ \\
\hline Family & $\begin{array}{l}\text { An important unit, } \\
\text { composed of father, } \\
\text { mother (or mothers in } \\
\text { polygamous homes) and } \\
\text { children }\end{array}$ & $\begin{array}{l}\text { Those without children } \\
\text { are considered incomplete } \\
\text { and under a curse. They } \\
\text { are generally not allowed } \\
\text { to offer solutions in the } \\
\text { community. }\end{array}$ \\
\hline Virtues to be emulated & $\begin{array}{l}\text { Bravery, courage, } \\
\text { kindness resilience, } \\
\text { heroism, sharing, } \\
\text { community }\end{array}$ & $\begin{array}{l}\text { Demonstrated in the lives } \\
\text { of heroes/heroines. }\end{array}$ \\
\hline
\end{tabular}




\section{Findings Generated by Interviews of Church Officers}

All three of the church officers have spent considerable time and effort in reaching the pastoralists. Parklea, the SDA Church elder working since the early 1980s, has been engaged in various witnessing activities such public evangelistic campaigns and sharing of literature among those able to read. Currently, he conducts radio programs in the Pokot language covering various topics that include health, family-life and SDA Church doctrines.

Pastor Rafael Wanyonyi, who serves as the Kitale SDA station director has ministered among the nomads in the region, including the Pokot. In addition to his current position, Wanyonyi also oversees SDA mission programs to the pastoralists in the Western Kenya Conference region.

On his part, Pastor Girimbe is responsible for the wider West Kenya Union territory, which is home to most pastoralists in Western Kenya. He is involved with the promoting, recruiting, and staffing of Global Mission Pioneers and also the directing of resources necessary for evangelism. In spite of the various challenges, these church officers expressed optimism for the work and made an appeal for support toward the work of evangelizing the nomads.

\section{Unreached Region}

The representatives of the SDA Church administration in Western Kenya stated that the pastoral communities in the region are largely unreached. Pastor Paul Girimbe noted that the Pokot, Samburu, Teso, Turkana, Tugen, Kuria, and the inhabitants of other 
regions such as Baringo, Uyoma, and Siaya are largely unreached. These are nomadic or semi-nomadic communities found within the Western Union territory. Both Girimbe and Wanyonyi stated that because urban centers are the main focus and emphasis of evangelism at the moment, countryside regions occupied by the Pokot, Teso, Turkana, Samburu, and Tugen are frequently sidelined. They noted that the entire region of West Pokot County has a few established churches in the urban centers such as Chepararia and Kapenguria, while other parts have few or no congregations. The directors' assessment collaborates with the East-Central Africa Division Unreached Assessment Report (See Appendix B), which shows that an SDA presence is minimal among the nomads and some communities are without any SDA presence.

One of the reasons cited as contributing to this state of witness and level of evangelism among pastoralists was the lack of entry points for mission. Girimbe stated that historically Seventh-day Adventists have depended on schools, medical facilities, and institutional centers for vulnerable populations as avenues to reach-out and equip workers for ministry yet these facilities are scarce or unavailable among the pastoralists. The three interviewees unanimously agreed that in the entire West Pokot County, only Chepararia health center and primary school are operational and serving a large population with health and educational needs. They argued that even though vulnerable populations such as the poor, orphans, and widows are continually increasing due to ethnic clashes and disease, there are no centers where such groups can receive basic necessities and have the opportunity to hear the gospel.

Girimbe reasoned that the felt needs of nomadic communities are numerous and diverse, yet response from the SDA Church is scarcely felt. There is inadequate food and clean water, a high rate of illiteracy, high poverty rates, frequent animal and human 
disease, mother and child health concerns, and poor infrastructure. Because these needs have not been adequately addressed by Seventh-day Adventists, most pastoralist communities have generally developed a perception that Adventism is out of touch with real life situations. Pastor Wanyonyi suggested that responses through food and clothing relief, construction of boreholes to supply water, veterinary services for animals, health centers and schools, and training in various trades to supplement family income could open doors for witnessing among the Pokot. Although some effort has been made to respond to the needs, it is still insufficient and unreliable.

\section{Inapt Mission Methods}

Methods of evangelism are also blamed for the ineffective witness. The three leaders observed that evangelism to the pastoralists involves the use of traditional methods of public preaching and presentation of abstract truths in a topical sequence using modern technology. Parklea, who is a Pokot himself, notes that this approach does not resonate with the pastoralists' cultural forms of communication. He said that even though the Pokot are primarily oral communicators who rely on stories, proverbs, riddles, and songs to relay information, most missionaries often emphasize the literal reading of Scripture.

Strict lifestyle teachings on dress codes and food choices in areas where Adventism had been introduced are incompatible with the Pokot context. Parklea indicated that Seventh-day Adventists emphasized lifestyle teachings such as diet, dress, and family-life lessons, and have constant negative attitude toward other denominations. "This turns off the heart of our people," Parklea declared. He narrated how an Adventist group witnessing in the region was forced to leave before finishing their campaign when 
they made negative remarks on another denomination that had been offering aid to the nomads. The pastoralists wondered how the visiting group of Seventh-day Adventists who had been present for only a few days in the community could insult other Christians who had spent significant time in the community, lived among the people, and were now running a health center. Wanyonyi noted that in some regions where Adventism has been introduced, most Pastoralists are resistant to the message partly because of the negative attitude that is held toward other Christian groups.

\section{Inadequate Missionaries}

Inadequate witness is a challenge for mission-work in Pokot. The three church leaders noted, for example, that in the whole region of West Pokot County, which is home to over 720,000 people, there are only two poorly equipped SDA pastors ministering to the nomads' spiritual needs. These ministers are located in urban centers where some nomads are more settled and accessible, leaving the rural areas without spiritual care or pastoral ministry. The two pastors are assisted by a few Global Missionary Pioneers, who are mostly dependent on aid from unreliable donors and wellwishers for their upkeep. Because of poor or no training in cross-cultural mission and an irregular salary, most of these workers abandon the work or are incapable of serving effectively.

It was noted that support from the conferences or union is also lacking and is, therefore, a major challenge for ministry among the pastoralists. Pastor Wanyonyi stated that he experienced inadequate support from the church administration in spite of frequent requests to have additional staff and funds, translate songs for worship, train oral communicators, and empower lay groups to enhance the work in Pokot. The union and 
conference officials countered the argument by stating that a training program for workers in nomadic contexts was already underway at the University of Eastern AfricaBaraton. Although it was verified that training was taking place, the officials noted that most of the graduates prefer to work in urban centers where living is more comfortable than in rural areas. Citing the current focus on cities, the conference church official argued that mission emphases were at times directed from higher levels of the organization regardless of local needs.

\section{Nomadism}

The itinerant lifestyle of pastoralists is viewed as a hindrance to effective gospel proclamation. Pastor Wanyonyi stated that it is a challenge to access pastoralists who spend long periods in the fields looking after their animals. He noted that in some regions, pastoralists are away for up to three months searching for pastures and water. This is worse during dry seasons, when the nomads crisscross boundaries, going as far as Uganda. Wanyonyi argued that even after baptism has taken place, following up or nurturing new believers is nearly impossible. He noted that nomads such as the Pokot require someone who can walk among them, live in their tents, listen to their experiences, and offer spiritual care.

Apart from the difficulty accessing pastoralists, there is the challenge of finding missionaries who are willing and equipped to serve the pastoralists. Paul Girimbe noted that after graduation from the regional seminaries, most pastors prefer, or are better equipped to work among settled communities than among nomads. These graduates often look forward to settling down, having a family, and pursuing further education, all of which are not possible if they serve among the nomads. As a result of these challenges, 
pastor Girimbe argued that Global Mission workers who are drawn from among the nomads are the most suitable personnel for pastoralists since they are familiar with their lifestyle.

The Pokot valued cultural practices were alluded to as additional hindrances to witnessing and contributing factors to the negative response toward the gospel. Practices such as polygamy and female genital mutilation were cited as obstacles for accepting biblical teachings since they are completely antagonistic with Christian beliefs. Pastor Girimbe said, "Polygamy is still widely practiced among the pastoralists. It is generally expected that Pokot men with many cows are entitled for larger families involving many wives as a sign of wealth They cannot comprehend living outside of the society beliefs of an ideal wealthy man."

Concerning FGM, Parklea indicated that even though FGM is a major health risk and is generally outlawed, it is still valued and espoused. The Pokot view FGM as an indispensable rite of passage for girls transitioning into womanhood. One informant mentioned that a Pokot girl who has not undergone FGM will live in shame, fetch lower bride price (dowry) for her family, and will be suspected of infidelity since the practice is also meant to decrease sexual desire when the men are away in the fields.

\section{Poor Communication}

Poor infrastructure and lack of modern technology were mentioned as an underlying factor affecting the state of SDA mission in Pokot. Even with the development of a tarmac road from Kapenguria across West Pokot County to South Sudan, the availability of mobile phones, and the rural electrification programs that supply electricity in some regions these projects have not been fully realized in all 
regions. The electrical supply is unreliable; the tarmac road is poorly maintained and unsafe in some parts that are inhabited by bandits and heavily-armed cattle rustlers.

Furthermore, the terrain in the Pokot region includes rugged mountains without proper passage to people's homes. Pastor Wanyonyi recalled how he and some believers spent over eight hours walking from one village to another on a dusty path filled with thorny shrubs because there were no other means of transport. He testified of his personal experiences stating that nurturing believers in such conditions is understandably difficult or nearly impossible. One informant also remembered how in a distant region away from an urban center, believers were neither served the holy communion because they did not know what to do without an ordained elder or minister nor did they congregate with others for annual camp-meetings for over three years due to transport difficulties.

In addition to dealing with witnessing and nurturing difficulties due to poor infrastructure, the three church officials agreed that keeping track of church members and updating church records is also a difficult task. Although this challenge is partly associated with the itinerant lifestyle of the nomads who migrate into neighboring Uganda, the lack of transportation for pastoral visitation is also to blame. Pastor Wanyonyi said that an influx of motorcycles for public transport has improved visitation programs, but this is also limited to certain areas.

\section{Analyses and Missiological Implications}

Research of the Pokot cultural worldview highlights two main categories of mission challenges that witnesses have to contend with: socio-economic and missiological challenges. Figure 6 further illustrates these tasks. 


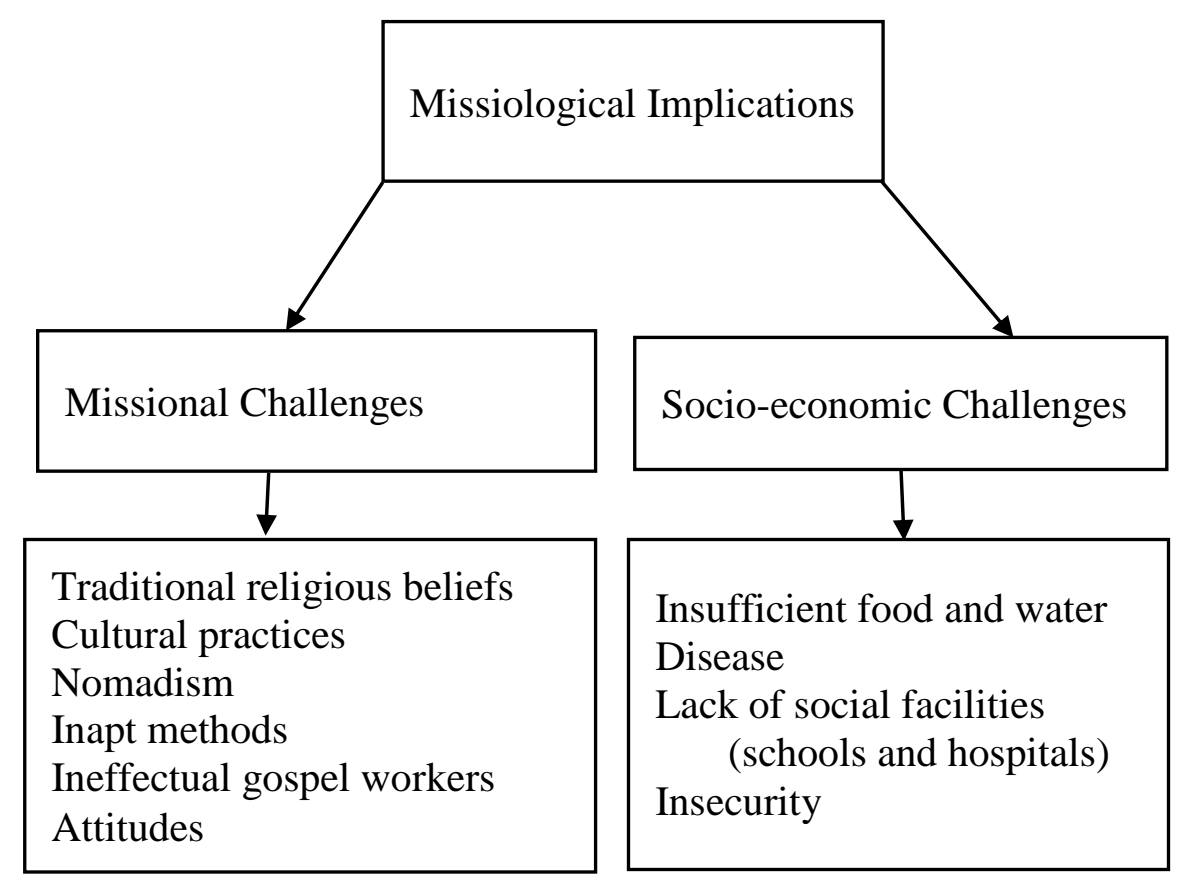

Figure 6. Summary of missiological implications

\section{Traditional Religious Beliefs}

John Mbiti has described Africans as "notoriously religious" 34 and this is true of the Pokot people. Even though Christianity has been in existence in Pokot for over eighty years now, ${ }^{35}$ adherence and devotion to traditional religious beliefs is still strong and commonly practiced. Most people are deeply committed to the worship and fear of Tororot (god) as evidenced by numerous rituals and sacrifices often accompanied by songs and dances. These are frequently conducted at Mount Kadem and other sacred places, such as caves, hills, and riverbanks where spiritual beings are believed to exist.

\footnotetext{
${ }^{34}$ Mbiti, African Religions and Philosophy, 1.

${ }^{35}$ Anglican Church of Kenya, "The Church History."
} 
The fear of ancestral spirits is also widely practiced. As Bollig also asserts, ${ }^{36}$ ancestral spirits play a significant role in the lives of the Pokot. Apart from providing guidance, spirits are also revered as messengers from dead relatives who are constantly watching over the living. Animal sacrifice, religious ceremonies, and rituals to appease the spirits, are regularly conducted in order to escape curses and spells from displeased ancestors. It is widely believed that unpleased spirits of the dead cause disasters in the form of disease and unexplained misfortunes such as sudden death. ${ }^{37}$

Commitment to Pokot religion is also seen during dedication of animals and family members. This practice is marked by offering of prayers that seek for blessings for grass, rain, and health. The prayers are often accompanied by singing in praise of the divine and petitioning the gods during significant occasions throughout life. In addition to prayers and numerous rituals, a belief in sacred places such as mountains, rivers, caves, and trees is common. Daily human activities in these sacred places are forbidden since they are assumed habitations for the divine beings and ancestral spirits and therefore unapproached unless authorized.

These unbiblical practices are contrasted with fundamental Christian teachings. Scripture presents God as one who is loving (Deut 7:9; John 3:16; Rom 5:8; 1 John 4:911), forgiving (Isa 1:18, 43:25; Matt 6: 14-15; Acts 3:19; 2 Cor 5: 17; Eph 1:7; Heb 10:17; 1 John 1:9), and patient (Num 14:18; Exod 34:6; Ps 86:15, 103:8; Joel 2:13; 1 Pet 3:20), among other attributes. While the basis of worship among the Pokot is fear, the principle nature of worshiping the God of the Bible is love that is founded in the gospel,

\footnotetext{
${ }^{36}$ Bollig, Risk Management, 36; Lokwei, “Conflict and Cultural Change.”

${ }^{37}$ Schneider, The Africans, 191; Bollig, Risk Management, 36.
} 
which also invites humanity to respond freely and willingly. This love is manifested in God's forgiving character in spite of humanity's depravity. ${ }^{38}$

The belief in continual existence of the dead in spirit form (immortality) held by the Pokot is also critical for SDA mission. Based on biblical evidence, the church holds a position that only God is immortal (1 Tim 1:17) because God alone is uncreated, selfexistent, and without beginning or end. As a member of the trinity, the Holy Spirit also possesses similar divine attributes and contributes in the salvation process through teaching, reminding, convicting, and comforting, among other roles (John 14:18, 26, 16:8, Acts 9:31; 1 John 2: 27).

On the other hand, the Scriptures are clear that humans are mortal and subject to death (Job 14:2, 10-12; Ps 78:39; James 4:14). The death experience or temporal unconsciousness is a result of $\sin ($ Rom 6:23) and is often referred to as "sleep" (1 Kings 2:10; 11:43; Job 14:10-12; Ps 13:3; Eccl 9: 10; Matt 9:24; John 11:11-14; Acts 7:60; 1 Cor 15:51, 52; 1 Thess 4:13-17).

Ellen white has indicated that in the last days, a belief in the conscious state of the dead will be one of the last deceptions that Satan will use to ensnare God's people in falsehood. ${ }^{39}$ Basing their arguments on scriptures such as Ecclesiastes 12:7, which state that at death the body returns to dust and the spirit returns to God, some suggest that this is evidence that the essence of a person continues to exist after death. However, a harmonious study of Scripture reveals that "neither the Hebrew nor the Greek term for

\footnotetext{
38 Tom Hale and Steve Thorson, "1 John 4: 7-21," Applied NT Bible Commentary (Colorado Springs, CO: David C. Cook, 2012).

${ }^{39}$ Ellen G. White, The Great Controversy (Nampa, ID: Pacific Press, 1996), 556.
} 
spirit, ruach and pneuma respectively, refers to an intelligent entity capable of a conscious existence apart from the body. Rather, these terms refer to the "breath" - the spark of life essential to individual existence, the life principle that animates animals and human beings." 40

Therefore, since death is a consequence of $\sin ($ Gen 3:19; Rom 6:23), the hope for humanity regaining life after death is solely based on believing in the sacrificial death of Christ on behalf of humanity (Rom 6:23, 1 John 5:11; 2 Tim 1:10; 2 Cor 15:22). The Bible teaches that a full restoration to life without end is an eschatological event to be realized at the resurrection (1 Thess 4:13-17). To produce this biblically based belief on issues of life and death among Pokot converts and believers is a fundamental goal for SDA mission workers.

Since SDA missionaries will constantly confront these worldview traditions and belief systems, a model for mission that allows reflection and change is necessary. To address Pokot religiosity by focusing on their fundamental fears, and leading them to find answers for the unknown is at the core of Christian witness to this people group. Time, patience, and suitable methods of communicating biblical truths that will transform their deep religious and cultural background are of the essence since quick fix strategies commonly employed to witness are insufficient. ${ }^{41}$ Even after conversion, believers from such backgrounds will need constant spiritual care and ample time for reflection in order

${ }^{40}$ General Conference of Seventh-day Adventists, Seventh-day Adventists Believe, 353.

${ }^{41}$ Methods such as public evangelism, short term witnessing, or casual lessons from Scripture do not allow time for building relationships, trust, reflection, and informed responses, which are necessary ingredients for Bible-based witnessing. 
to develop transformed and mature Christian responses and lives. ${ }^{42}$ This will also assist in breaking the tendency of converts from such worldview to revert to old religious practices that often provide comfort during crisis. ${ }^{43}$

\section{Socio-economic Needs}

Socioeconomically, numerous challenges confront the Pokot people. Insecurity related to frequent tribal clashes, ${ }^{44}$ poor infrastructure, land disputes, and the proliferation of weapons are among the social upheavals with which the community contends. This is in addition to a lack of adequate and well-equipped social amenities such as hospitals, clinics, and schools. Consequently, high mortality rates, illiteracy, malnutrition, disease, ${ }^{45}$ and continuous increase of large numbers of destitute people — orphans, widows, and the poor-are in part results of the social challenges. ${ }^{46}$

Another social challenge that hinders effective witness is skepticism and suspicion. Because of the historical experiences of colonialism and modern attempts to

\footnotetext{
${ }^{42}$ Stephen B. Bevans and Roger P. Schroeder, Constants in Context: A Theology of Mission for Today (Maryknoll, NY: Orbis Books, 2004), 385.

${ }^{43}$ Boubakar Sanou, "Responding Biblically and Missiologically to the Threat of Religious Syncretism,” Journal of Adventist Mission Studies 9, no. 2 (2013): 94-109.

${ }^{44}$ Paul Spencer, Time, Space and the Unknown: Maasai Configurations of Power and Providence
} (New York: Routledge, 2003), 16. In addition to cross-border weapons trafficking, cultural practices of moranhood that require young warriors to engage in cattle rustling are also causes of ethnic or clan clashes.

${ }^{45}$ Nancy Johnson and Ayago Wambile, eds., "The Impacts of the Arid Lands Resource Management Project (ALRMPII) on Livelihoods and Vulnerability in the Arid and Semi-Arid Lands of Kenya," International Livestock Research Institute, 2011; USAID, "Understanding Nutrition Data and the Causes of Malnutrition in Kenya," Famine Early Warning Systems Network (September, 2006); Abdikarim Sheik-Mohamed and Johan P.Velema, "Where Health Care Has No Access: The Nomadic Populations of Sub-Saharan Africa," Tropical Medicine and International Health 4, no. 10 (October 1999), 695-707.

${ }^{46}$ See for example, Pokot Turkana Peace Initiative "We are your Orphans," accessed November 11, 2016, http://www.pokotturkanapeaceinitiative.com/sponsor-an-orphan.html; Harvesters International “Chemolingot Children's Home," accessed December 23, 2016, https://harvesters.net/chemolingotchildrens-home/. 
settle nomadic people through development projects, the Pokot and other pastoralists are generally distrustful toward outsiders or those who propose change. ${ }^{47}$

Economic challenges include insufficient food sources, poor infrastructure, and a general scarcity of natural resources. Even though crop farming is practiced in some regions of Western and Northern Kenya, a larger portion of land is dry with prolonged droughts, high temperatures, and inadequate pastures for animals. Crop farming in these parts is rare, and people are generally dependent on animal products for their survival. The one meal per day schedule is a result of insufficient food conditions caused by the unproductive land. Their dependency on livestock as the only source of food products milk, meat, and blood-partly explains why cows are highly valued.

Shortage of natural resources is also attributed to frequent movements across established boundaries ${ }^{48}$ and the root cause of the unending ethnic clashes among the pastoralists. ${ }^{49}$ The scramble for available resources is viewed as a key contributor to destruction of property, loss of life, and human displacement, a chief characteristic of life among pastoralists.

\footnotetext{
${ }^{47}$ Elliot Fratkin, Martha A. Nathan, and Eric Abella Roth, "Is Settling Good for Pastoralists?" accessed October 23, 2016, http://www.saga.cornell.edu/saga/ilri0606/23presentation.pdf.

48 "Kenya: The Dangers of Pastoralism," IRIN, accessed January 10, 2016, http://www.irinnews .org/Report/85252/KENYA-The-dangers-of-pastoralism.

${ }^{49}$ For more information on ethnic clashes among the nomads, see "Kenya: Drought Exacerbating Conflict among Pastoralists," IRIN, accessed December 10, 2015, http://www.irinnews.org/Report/82683 /KENYA-Drought-exacerbating-conflict-among-pastoralists; "Conflict Assessment: Northern Kenya," Pragya Kenya; Terry Mwaniki et al., Conflict Management: Joint Case Study of North Rift Region of Kenya (Nairobi, Kenya: Paulines Publications Africa, 2007), 23. The frequent bloody ethnic clashes among the pastoralists are attributed to the scramble for limited resources. The Northern and Western Kenya clashes have increased over time and are mostly related to disputed sources of water and pastures, competition for cattle, unclear land ownership, proliferation of weapons from war-torn neighboring countries, and historical rivalry among the pastoral communities.
} 
The socio-economic challenges presented require a rounded approach, which will address religious as well as physical needs. Since the gospel of Christ is proclaimed both word and deed, ${ }^{50}$ The SDA Church is challenged to rise to the occasion to meet the Pokots' felt needs in addition to proclaiming the gospel. Through its holistic approach to ministry, the church will have to respond to human needs as a way of building trust and building of mission bridges for sharing the gospel.

\section{Communication Tasks}

Communication tasks involve the dynamics that would be best used to share the gospel among the Pokot. First, the concept of orality is central to Pokot culture. Like most pastoral communities in the region, the Pokot communicate primarily through proverbs, stories, songs, riddles, and dances. Their history is not written in books but in their memory. They possess no scriptures as a basis for their religion, but they have religious teachings in stories, proverbs, and songs. Prayers are also offered in song or chants that are also used for instructing, admonishing, rebuking, and teaching cultural values such as generosity, humility, obedience, respect, and kindness.

Second, the research and literature review indicate that not all Pokot cultural values are antagonistic with biblical teachings and practices. Biblical values such as kindness, humility, respect for the elderly, honesty, morality, and hospitality, which believers are urged to emulate, resonate with Pokot cultural values as well. Scripture urges believers to treat others as one would want to be treated (Luke 6:31; Col 4: 1-18),

${ }^{50}$ Edward L. Smither, "Word and Deed," in Mission in the Early Church: Themes and Reflections (Eugene, OR: Cascade Books, 2014), 127-148. See also David Bosch argument that evangelism is not only verbal communication, in David J. Bosch, Transforming Mission: Paradigm Shifts in Theology of Mission (Maryknoll, NY: Orbis 2011), 428. 
to be kind and forgiving to one another (Micah 6:8; Eph 4:32), to show hospitality even to strangers (1 Pet 4:9; Rom 12:9-13; Heb 13:1-3), to seek all the fruits of the Holy Spirit (Gal 5:22-23), to love at all times (Prov 17:17), to be generous (Matt 25:35, Rom 12:13), and to be kind, sympathetic, and humble (1 Pet 3: 8-12; Col 3:12-14; 1 Cor 13: 1-13). These virtues are also promoted among the Pokot and encouraged from childhood.

An analysis of Pokot orality and cultural values raises two fundamental missiological conclusions. First, since God not only speaks to culture but also through culture, the Pokot cultural values listed above should be encouraged and emphasized. Missionaries should employ them as bridges to share Jesus Christ who is the ultimate source of virtuous living. Missionaries should begin with these known lessons and transition to the unknown biblical teachings. Other cultural practices such as polygamy, which are clearly against biblical teachings, will require a change of worldview through Bible studies so that believers ground their lives in the revealed will of God. The second conclusion is the importance of effective communication. Communicating biblical truths with the pastoralists will require employing oral strategies such as proverbs, stories, songs, riddles, and other means with which they are accustomed.

\section{Summary}

Chapter 4 presented findings of qualitative research I conducted in the summer of 2014. A description of the research process and the parameters which guided the study, are spelled-out. Since objective data in ethnography is crucial, a flexible method that allowed free interaction with the study subjects and informants was adopted. This included interviews with three separate groups of elders and informants and observation of daily life activities and ceremonies, which revealed pertinent information about the 
Pokot cultural worldview. Analyses of data through the Content Analysis Method gave rise to critical implications for mission that are discussed in the last part of the chapter.

In general, the Pokot people hold differing opinions regarding their origins. While some claim that they migrated from South Sudan alongside other Nilotic groups in the East Africa region, others claim that they defected from various groups with whom they share cultural values. Information about origins is vague and dependent on whoever is interviewed.

Apart from their displeasure and suspicion of outsiders who propose changes to their culture and lifestyle, the Pokot people are sociable, generous, and respectful of the elderly and visitors. Religion plays a key role in their life. Rituals and ceremonies for the appeasement of the divine and the ancestral spirits are commonly practiced.

Out of this study, various missiological challenges emerged. Besides sharing the gospel, response to human needs is fundamental. The pastoralists are faced with dire hardships of drought, disease, ethnic clashes, and lack of development caused by poor infrastructure and marginalization. For SDA mission to be more relevant and meaningful in the community, meeting the basic needs of the people is inevitable and necessary. The Church will have to adopt a model that addresses these multiple challenges in a holistic manner.

The following two chapter present a model to guide SDA mission and ministry among the pastoralists in light of their cultural and socio-economic context. The chapters examine key missiological strategies that will potentially expedite witness and advance the course of Christian faith among the nomads of Kenya. 


\section{CHAPTER 5}

\section{A MODEL FOR MISSION AND MINISTRY IN LIGHT OF THE POKOT CULTURAL WORLDVIEW: MISSIONAL RESPONSES}

\section{Introduction}

The socio-cultural dynamics discussed in Chapters 3 and 4 have regularly impacted SDA mission efforts among the nomads of Western and Northern Kenya. Inadequate and smooth transmission of the gospel due to inappropriate or unproductive methodologies employed that fail to address the social as well as cultural challenges are partly a cause for the plateaued state of SDA witness. Consequently, the Church is challenged to re-examine the current conventional strategies used to evangelize nomads since these approaches have failed to effectively witness adequately or respond to the nomads' socio-economic needs. In place of the existing methods, relevant, creative, and effective strategies are needed if a more dynamic SDA mission presence in the region is to be realized.

In this chapter and the next, a comprehensive model of mission to guide SDA witness among pastoralists is proposed. The developed model examines seven key crosscultural strategies that address cultural, socio-economic, and communication barriers for efficient ministry. Of the seven approaches, worldview transformation, contextualization, and effective communication are discussed in this chapter. The last four strategic 
approaches that focus on building bridges for mission, that is, incarnational ministries, specialization, strategic prayer, and group-oriented evangelism are presented in chapter 6.

\section{The Need for a Mission Model}

In various missiological forums, the need for an ideal model to guide Christian witness among nomads has been a key topic. ${ }^{1}$ It is often noted that numerous sociocultural factors arising from the vast and complex contexts of nomads worldwide have partly kept the gospel from effectively reaching people; therefore, this quest for suitable methodologies.

Among the barriers, unfamiliarity with and misunderstanding of nomadic cultures is the single greatest reason pastoralists are still largely unreached. ${ }^{2}$ Missionaries from settled backgrounds often find it challenging to witness to nomads whose lifestyle of constant movement and unique cultural orientation they find quite foreign. ${ }^{3}$ This research attempted to uncover the deep cultural values of the Pokot in order to advance the process of sharing the gospel more effectively.

Among the revelations of this study, the communal lifestyle of the pastoralists was identified as a significant barrier for proper communication and for obtaining the

\footnotetext{
${ }^{1}$ A mission model for nomadic contexts is a need generally recognized and championed by those who have extensively researched and worked among nomads. See Jason Mandryk, Operation World: The Definitive Prayer Guide to Every Nation (Colorado Springs, CO: Jason Mandryk and GMI, 2010), 100; Hunter, "Think Nomadic," 9-13.

${ }^{2}$ Hunter, “Think Nomadic," 9-13.

${ }^{3}$ Malcolm Hunter, "The Challenge of Reaching Nomadic Pastoralists," International Journal of Frontier Missions 14, no. 4 (October-December, 1997): 183-190. The common desire in missionaries to have a house is impractical in nomadic situations. Other challenges include the possibility of inviting in poor, destitute, and dependent nomads who have lost their property are in need of material support.
} 
desired response to the gospel. In place of methods that involve group decision-making, most mission entities use models that are rooted in Western individualistic worldviews. These foreign models tend to appeal to the individual — a personal conversion experience, a personal piety, and a personal relationship with God, among other emphases. ${ }^{4}$ Because group-based decision making is central to nomads' cultural values, the individual-focused tactics are largely irrelevant to and inconsiderate of the nomads' ways of life. Such approaches fail to accommodate the community in the witnessing process, thereby alienating pastoralists and keeping them from hearing the gospel. For nomads, personal resolutions or pursuits do not replace group values. ${ }^{5}$

Second, apart from a deep-seated cultural worldview that limit outside influences seeking change, pastoralists also experience physical, economic, and social hardships. Some of the challenges identified include scarcity of resources such as water, food, pastures, infrastructure, security, and social amenities. ${ }^{6}$ Since response to human need is an important part of Christian mission, it is imperative that SDA mission among nomads should address these challenges along with the proclamation of the gospel.

A third factor hampering effective mission deals with the unhealthy relationships existing between most nomads and settled peoples. Ethnocentric attitudes describe the

\footnotetext{
${ }^{4}$ Rabbi B. Albin, A Spiritual History of the Western Tradition (Raleigh, NC: Lulu, 2008), 117. Emphasis on personal experience is the foundation of the evangelical movement, which also dominates protestant Christianity and witness. 298.

${ }^{5}$ Chesaina and Swinimer, The Pokot, 17; Bollig, Schnegg, and Wotzka, Pastoralism in Africa,

${ }^{6}$ For examples of the challenges with which nomads contend, see Zakaria Godson Maro, Peter Ngatia Nguura, and Jemal Umer, Understanding Nomadic Realities: Case Studies on Sexual and Reproductive Health and Rights in Eastern Africa (Nairobi, Kenya: KIT Publishers, 2012).
} 
nomads' view of settled people and vice versa. ${ }^{7}$ Deep-seated attitudes of inferiority, superiority, and skepticism are widely reported and are the cause of acts of intolerance and ethnic clashes between these two groups.

As mentioned in Chapter 4, most nomads hold negative opinions about settled people. They consider themselves economically superior to others because animal products such as meat, milk, hides, leather, and wool cannot be produced by crop farmers. ${ }^{8}$ From an ethnocentric perspective and because of their love for traveling, nomads also consider settled people as alien, inferior, enclosed, unhealthy, unclean, and even unholy. ${ }^{9}$ Others, particularly those with a Muslim backgrounds, view their own esteemed origins and religious practices, such as long and frequent prayer sessions as more spiritual than those of settled people. ${ }^{10}$ Skepticism toward outsiders and their influences are also common among the pastoralists due to previous interactions with those who came to colonize or appropriate their land.

On the other hand, settled people also harbor prejudice against pastoralists. Limited development in nomadic areas and biases created by the media paint a negative picture of nomadism and this has influenced settled people's view of pastoralists as poor,

\footnotetext{
${ }^{7}$ Carlo Caldarola, Religion and Societies: Asia and the Middle East (Berlin, Germany: Walter de Gruyter and Company, 1982), 156.

${ }^{8}$ Dawn Chatty, Nomadic Societies in the Middle East and North Africa: Entering the 21st Century (Leiden, Netherlands: Brill Academic, 2006), 82.

${ }^{9}$ Phillips, Peoples on the Move, 46.

${ }^{10}$ Ibid.
} 
fierce, unintelligent, and non-contributors to national development. ${ }^{11}$ Because they do not own permanent property such as houses and land, the pastoralists are often judged as economically dependent, headstrong, unwilling to change, lawless, uncivilized, criminal, subordinate, and as second-class citizens. ${ }^{12}$ As a result, they are frequently manipulated, left vulnerable, and generally neglected or abused. Although pastoralists make major contributions to national food security and economic prosperity, their efforts are unrecognized by most policy-makers, donors, and the public.

This hostility between nomads and settled peoples is a major barrier for church operations and witness. It hampers a positive environment necessary for evangelism and impedes the sharing of the gospel since most missionaries to nomads come from settled groups. Christian witness is usually received either with distrust or is perceived to be inferior to the traditional religion of the pastoralists. In order to overcome this gulf, a mission model that will assist in building trust, respect, mutuality, and sincerity for the benefit of sharing the good news is essential.

In summary, nomadic contexts are complex. For the SDA Church to make mission in-roads among the Pokot and other regions occupied by nomads, cultural, economic, religious, and social barriers that impede witness must be addressed. The

\footnotetext{
${ }^{11}$ For examples of stereotypes, discrimination, and prejudices against nomads see Mike Shanahan, "Media Perceptions and Portrayals of Pastoralists in Kenya, India and China," Gatekeeper, no. 154 (April 2013); Naomi Kipuri, "Indigenous Peoples' Rights to Lands, Territories and Resources Related to Discrimination in Employment and Occupation: Case Study on Practices of Pastoralism and HuntingGathering in Kenya," The International Labor Organization, February 2008; Phillips, Peoples on the Move, 47-48; Leandro O. Ogola, "Human Security in Pastoralist Areas of Eastern Africa," African Security Review 19, no. 3 (2010), 27-40.

${ }^{12}$ Phillips, Peoples on the Move, 42. Other recent studies attempting to uncover media perceptions and portrayals of pastoralists in Kenya, India, and China indicate that Kenyan pastoralists feature mostly in "bad news"- stories featuring conflict and drought. See Shanahan, "Media Perceptions and Portrayals."
} 
models of mission currently employed are insufficient in meeting the existing missional challenges, and this necessitates a more comprehensive approach.

\section{A Comprehensive Approach ${ }^{13}$}

In view of the complex socio-cultural dynamics discussed above, an approach that combines various lines of mission work is necessary. Experiences from other areas of engagement in nomadic regions indicate that a more inclusive and holistic approach is necessary when reaching nomads. ${ }^{14}$

A comprehensive approach combines theory and practice. It ensures that the primary goal of mission (sharing of the gospel) is conducted alongside appropriate responses to human needs. ${ }^{15}$ This approach should also aim at holistically addressing the various challenges nomads face because of their interconnectedness. It means, for example, confronting traditional religious beliefs that are antagonistic to biblical teachings while at the same time supplying water through the construction of wells, providing education through the building of schools, ensuring community health through

\footnotetext{
${ }^{13}$ In his dissertation, Gideon Petersen discusses and limits the Comprehensive Approach primarily to communication barriers that exist between the missionary and the nomad. See Petersen, "Ministry to Nomads," 21. In this study, comprehensiveness is expanded to include other components of cross-cultural mission.

14 "Policy Framework on Nomadic Education in Kenya," The Government of Kenya, accessed October1, 2016, http://planipolis.iiep.unesco.org/upload/Kenya/KenyaPolicyFrameworkNomadic Education.pdf. The government of Kenya through the ministry of education admits that education service delivery to nomadic population cannot be done in isolation from the social, cultural, and economic issues which need to be addressed as well. It is noted, for example, that education service delivery to the nomads often fails when cultural, economic, and social concerns are not addressed. In most cases, school age children are required to stay home to take care of animals, the only source of income. Similarly, insufficient rain is a cause of frequent mobility, resulting in clashes with other groups as they scramble for available basic resources. This suggests that if water were available, nomads would live and move within their boundaries, thereby avoiding clashes with other groups. Provision of these services, therefore, requires a multi-sectoral approach.

${ }^{15}$ Panagiotis E. Petrakis, Culture, Growth and Economic Policy (New York: Springer, Science, and Business Media, 2014), 9.
} 
clinics and hospitals, and establishing community development programs that uplift the community's standard of living.

Specific aspects of the following strategies are limited and beyond the scope of this study. Developing practical and precise steps is better suited to the field. Further inquiry into the implementation of the suggested approaches is recommended.

\section{Worldview Transformation}

Transforming converts from unbiblical cultural worldviews and practices to an understanding of the gospel is fundamental to Christian mission. The study of the converts' lifelong beliefs is necessary since people from all cultural backgrounds are called to spiritual reformation, which encompasses the renunciation of sin and a return to God as Creator and Lord. ${ }^{16}$ New believers are encouraged to examine their preconceived ideas about the world, origins, God, sin, death, destiny, tragedy, and other key worldview assumptions as a foundational step toward becoming mature Bible-based Christians, the ultimate goal for mission. ${ }^{17}$ In this process, unbiblical cultural beliefs and practices need to be discarded, paving the way for spiritual transformation, growth, and sanctification.

It is advisable from the initial steps of evangelism for mission workers to address the core cultural beliefs of the target group. ${ }^{18}$

\footnotetext{
${ }^{16}$ Hiebert, Transforming Worldviews, 307.

${ }^{17}$ May, “Cultures and Worldviews,” 388.

${ }^{18}$ Bruce L. Bauer, "The Importance of Worldview Change in the Discipling Process," Journal of Adventist Mission Studies 12, no. 2 (2016): 184-193. Bauer suggests that newly baptized Adventist church members should have a conversion experience that goes deeper than outward behavior or change of belief system. This can only be possible if more time is spent teaching and discipling new converts rather than relying on short-term evangelistic campaigns which are insufficient to change deep and life-long held
} 


\section{Reasons for Worldview Transformation}

Mission studies indicate that conversion without a change of one's underlying worldview assumptions is a primary cause of unbiblical practices in most Christian congregations. ${ }^{19}$ Unorthodox practices such as superficial surface-level conversion, minimal behavior modification, syncretistic practices, and dual allegiance are consequences of improper witness related to a lack of worldview change. ${ }^{20}$ Paul Hiebert admonishes Christians to:

move beyond immediate ministries to the long and difficult task of transforming people's animistic worldviews into biblical ones. Working within traditional Christian explanation systems, there is a real danger that the gospel will be transformed into Christo-paganism - animism with a Christian veneer. New Christians often see Christian prayer as magic formula, Bible verses as amulets and preachers as magicians more powerful than their old ones. Christianity is perceived as powerful witchcraft and spiritism, and the fear of spirits remains. ${ }^{21}$

For Seventh-day Adventists, worldview change is an important biblical concept with eschatological implications. It includes experiencing biblical conversion summed up in the understanding of the eternal gospel proclaimed in Rev 14:6. ${ }^{22}$ This fundamental change includes accepting the trinitarian authority - God as the Creator of the world, Jesus Christ as a personal Savior, and the Holy Spirit as the agent of salvation. This

beliefs. See also Loh Hung Chey, "The Change Process," in Transforming into Christlikeness (Guildford, UK: Genesis Books, 2011), 67-72.

${ }^{19}$ See for example, Kelvin O. Onongha, "Towards a Missiological Model for Worldview Transformation among Adherents to African Traditional Religion in Yorubaland" (PhD diss., Andrews University, 2014); Paul A. Dosumu, "Missiological Study of the Phenomenon of Dual Allegiance in the Seventh-day Adventist Church among the Yorba People of Nigeria" (PhD diss., Andrews University, 2010).

\footnotetext{
${ }^{20}$ Van Rheenen, Christ in Animistic Contexts, 89.

${ }^{21}$ Hiebert, Shaw, and Tienou, Understanding Folk Religion.

${ }^{22}$ Lichtenwalter, "Worldview Transformation and Mission,” 211-212.
} 
unique expression of the biblical worldview by Seventh-day Adventists should shape the Church's mission, identity, and message among pastoralists. $^{23}$

As an eschatological goal, worldview change aims at forming a true people of God who are spiritual, Bible-centered, and distinct from the world. Paulo Candido de Oliveira asserts, "The final goal of Adventist missions is worldview transformation leading to a biblically-shaped worldview. This will only be possible by understanding a people's worldview and analyzing it under the light of Scripture that will indicate the necessary changes to produce shifts in allegiance without compromising the cultural essences."24

A change of worldview benefits new congregations in many ways. It is necessary for the retention of new members since their allegiance shifts to God and they become grounded in God's will as revealed to them in Scripture. David Dockery notes that a new Christian worldview obtained by converts becomes a driving force for life that gives them a sense of God's plan and purpose for the world and also shapes their identity whereby they no longer see themselves as alienated from their Creator. More so, in the midst of life's challenges and struggles, a transformed worldview provides stability, anchoring believers to God's faithfulness and steadfastness. It gives confidence and hope for the future amid the uncertainties of life. ${ }^{25}$

23 Ibid.

${ }^{24}$ Paulo Candido de Oliveira, "Developing an Interdisciplinary Analysis and Application of Worldview Concepts for Christian Mission” (PhD diss., Andrews University, 2006), 192.

${ }^{25}$ David Dockery, “A God-centered Worldview," accessed December 10, 2016, https://www.gospelproject.com/2013/10/21/the-importance-of-a-christian-worldview/. 
The elimination of syncretism and dual allegiance is fundamentally possible when worldviews are transformed by old and new members alike. This is a necessary endeavor in developing mature Christians who are true to God and are effective witnesses. De Oliveira asserts that the gospel must maintain its disruptive qualities and bring radical change in both individual and community life from generation to generation. ${ }^{26}$ SDA mission practitioners must therefore work toward ensuring that Pokot converts are fully exposed to the biblical worldview so as to establish spiritually strong ethnic congregations.

\section{Methods for Transforming Worldviews}

Seeking to change the way people believe and live is a challenging undertaking. Missiologists and anthropologists agree that changing cultural worldviews is a process requiring time and patience and is not a one-time event. Just as worldviews are formed and shaped over time through associations, experiences, and explanations, a change worldview will equally require time and the necessary tools to help people evaluate their existing beliefs in light of those being introduced. ${ }^{27}$

According to Charles Kraft, worldview change occurs when a new perspective is gained. ${ }^{28}$ The development of such views is often the result of extensive explanations and

${ }^{26}$ de Oliveira, "Developing an Interdisciplinary Analysis," 192.

${ }^{27}$ Baumann, Worldview as Worship, 17. Baumann argues that transformation of a worldview is a paradigm shift, a new way of thinking where a new theory emerges and is accepted by the community as a better explanation than the previous. For such a change to develop, it requires the development of cultural tools that will assist in resolving conflicts, rather than creating random events that stimulate the questioning of the existing worldview. Establishing a biblical worldview will thus demand the development of spiritual tools that will allow believers to evaluate values of the dominant society in light of the description of the normative aspects of worldview expressed in Scripture.

${ }^{28}$ Kraft, Anthropology for Christian Witness, 359. 
experiences that challenge existing assumptions which have always provided answers and meaning to a community. Some of the valuable biblical, missiological, and cultural tools that can be used to initiate a change process among the Pokot and other pastoralists include strong interpersonal relationships, Bible studies, story-telling, and overcoming negative attitudes.

\section{Developing Strong Relationships}

Close relationships and associations are vital for the development and shaping of worldviews. This is more apparent in African societies where for example younger people learn from their elders until they come of age. In these societies, there are shared values, belief systems, and motivations. ${ }^{29}$ The communal ideology that defines African societies often leads people to view life in almost the same way. It is in such close relationships, manifested in group life, that worldviews are either formed or reinforced. Within community-based societies such as the Pokot, with close relationships and shared experiences, and where individual decisions are less valued, worldview transformation must begin and be focused at the group level.

One strategy that has been used to encourage close relationships and could be implemented to develop and enhance close relationships among the Pokot is the formation of interest-related groups. ${ }^{30}$ When common agendas cause people to come

${ }^{29}$ Phiri, Social-Cultural Anthropology, 24.

${ }^{30}$ Interest-related groups are mostly formed by people who pursue particular interests in unison. Interests could be in a form of business, politics, and health, among other topics. In the case of the Pastoralists, interest groups can be based on grazing land management, care of water resources, or solidarity in seeking justice. For more information on formation and benefits of interest groups, see "Motivations behind the Formation of Interest Groups," Boundless Political Science, accessed April 20, 2016, https://www.boundless.com/political-science/textbooks/boundless-political-science- 
together for a unified pursuit, catalytic conversations occur. ${ }^{31}$ This environment for dialogue is necessary for introducing new perspectives on life, leading people to examine their preconceived assumptions in light of new experiences.

Strong relationships also enable ministry to people in a group setting. This is advantageous for the Pokot who are communally based and whose values include group decision-making. This view is supported by Strauss and Steffen who state that "parachuting into a community without engaging in authentic friendships and understanding a society's worldview is not effective in the transformation process." ${ }^{\prime 32}$ Missionaries should be encouraged to use these valuable cultural structures to further develop healthy congregations where faith and Christian virtues will develop and grow a biblical worldview.

\section{Bible Studies}

A study of the Bible is central to the development of a biblical worldview. As the revealed will of God, the Bible provides a believer with teachings regarding God, origins, sin, salvation, tragedy, destiny, and other lifelong puzzling questions. In order for converts to obtain genuine, permanent, and authentic Christian transformation - the goal

textbook/interest-groups-7/interest-groups-47/motivations-behind-the-formation-of-interest-groups-280$3551 /$.

31 Ann C. Baker, Catalytic Conversations: Organizational Communication and Innovation (Armonk, NY: M.E. Sharpe, 2010), 4. Baker indicates that catalytic conversations are a favorable ground for inspiring and provoking change with less energy. Such conversions involve listening that leads to substantive change through constructive controversies and the creation of new knowledge. Conversations in interest-related groups also enable asking questions, exploring differences, sharing experiences and stories, and new light shed, which are necessary for worldview transformation.

${ }^{32}$ Robert Strauss and Tom Steffen, "Change the Worldview, Change the World," Evangelical Missions Quarterly 45, no. 4 (October, 2009): 463. 
of Christian witness, ${ }^{33}$ - Bible studies are indispensable. Prompt systematic Bible studies should be encouraged as soon as evangelistic programs begin and should continue throughout the believer's lifetime. ${ }^{34}$

In giving Bible studies to new believers, time is of the essence. Ample time for reflection and decision-making about what has been learned should be allowed in order to enable believers to personalize the message received. ${ }^{35}$ This implies that instant baptisms often conducted across the continent following public evangelistic events are insufficient for changing long-held perceptions about life. Such exercises do not allow converts time to process information and may result in unintended negative consequences such as syncretism and dual allegiance after missionaries leave the scene. In many cases, new converts revert to old belief systems they are familiar with when confronted with worldview realities such as sickness, death, and drought.

\section{Storytelling}

In spite of biases against communicating the gospel through stories, ${ }^{36}$ stories are valuable catalysts in the process of worldview change. In almost all cultures, stories are

\footnotetext{
${ }^{33}$ Van Rheenen, Communicating Christ, 90.

${ }^{34}$ Bauer, "The Importance of Worldview Change," 188.

${ }^{35}$ Chuck Sutton, "The Challenge of Religious Pluralism," in Overcoming the World Missions Crisis: Thinking Strategically to Reach the World (Grand Rapids, MI: Kregel, 2001), 140.

36 Tom A Steffen, "Why Communicate the Gospel through Stories," in Perspectives on the World Christian Movement, eds. Ralph D. Winter and Steven C. Hawthorne (Pasadena, CA: William Carey
} Library, 2009), 440. 
the most preferred, appropriate, acceptable, and effective cultural methods for communicating, teaching, and preserving people's values and concepts. ${ }^{37}$

The holistic character of stories allows them to touch not only the mind but also the heart and emotions, the center of worldviews. ${ }^{38}$ Steven Evans argues that unlike cognitive philosophies, instructions, and abstract propositions, stories touch the whole person, provoking tears, cheers, fear, anger, confidence, conviction, sarcasm, despair, and hope. $^{39}$

The need to connect people's stories to God's story is vital. Bruce Graham notes that people often desire to understand their history and origins. By telling and re-telling stories, a group's worldview and identity develops. ${ }^{40}$ Missionaries ought to be deliberate in connecting the people's stories about origins, the divine, evil, and destiny to the mega story_God's salvation. Without the link between human stories and God's story, the purpose of employing stories misses the mark and people are left "hopeless and without an enduring purpose" in life. ${ }^{41}$

The Pokot should be assisted in discovering their place and purpose on earth in light of God's story among the nations. Through the steps of critical contextualization,

\footnotetext{
${ }^{37}$ A. Steven Evans, "Orality, Story and Cultural Transformation: The Critical Role of Storytelling in Affecting Worldview and Values," accessed July 31, 2016, http://gnh-movement.org/papers/evans.pdf.

${ }^{38}$ Naugle, Worldview, 267-274; James A. Fyock, "The Effect of the Teacher's Worldviews on the Worldviews of High School Seniors" (PhD diss., Liberty University, 2008), 35-37.

${ }^{39}$ Steffen, "Why Communicate the Gospel," 441.

${ }^{40}$ Bruce Graham, "Transforming Worldviews through the Biblical Story," in Perspectives on the World Christian Movement, eds. Ralph D. Winter and Steven C. Hawthorne (Pasadena, CA: William Carey Library, 2009), 442.

${ }^{41}$ Ibid.
} 
Pokot cultural stories should be analyzed in order to build mission bridges that would convey biblical truths and values contained in Scripture. ${ }^{42}$ Following this approach, the unknown mysteries of salvation can be uncovered through the known, leading to transformation of the Pokot perspectives on fundamental worldview themes.

\section{Overcoming Negative Attitudes}

Unhealthy relationship between nomads and settled people is widespread. Nomads base their assumption on what they perceive as Western forms of Christianity and Christian development initiatives such as agriculture, technology, church buildings, hospitals, and schools. Basically they view Christianity as a religion of settled people. ${ }^{43}$ Without denying the possibility of nomads becoming Christians, most mission agents perceive nomadism as inconvenient and objectionable. They therefore seek to settle the pastoralists through development projects such as ranches and settlements in order to create suitable environments for them to evangelize.

These ethnocentric attitudes held by pastoralists and settled peoples is a hindrance that leads to suspicion and hatred of one another. These attitudes must be overcome to make space for cross-cultural evangelism. It needs to be affirmed that nomads contribute extensively to the world economy and in some instances they provide supplies that settled communities are dependent on. In addition, nomads are known to make use of the barren lands of the earth that are viewed as inhospitable to settled people. They also defend the

\footnotetext{
${ }^{42}$ Eugene A. Nida, God's Word in Man's Language (New York: Harper and Row Publishers, 1952), 21. He notes that even where there may seem to be an apparent inadequacy, there is no lack of words and phrases to express spiritual truths once the missionary has learned intimately the life of the people - there will always be rich spiritual significance in each culture's customs.

${ }^{43}$ Nida, God's Word, 47.
} 
borders of countries against invaders and contribute to the mosaic of world cultures.

Missionaries ought to be foremost in overcoming these negative presuppositions by developing a positive view of nomads as equal members of the human family.

\section{Contextualization}

Broadly defined, contextualization is "the process whereby Christians adapt the forms, content, and praxis of the Christian faith so as to communicate it to the minds and hearts of people with other cultural backgrounds." 44 This indispensable missional practice is founded on the precept that just as God the Son incarnated into our human sphere (Luke 1:35; Phil 2:5-8), the transforming biblical truths, which are universally-intended and applicable, are to permeate diverse human cultures.

In contrast to the past when most missionaries in foreign lands widely rejected the people's traditions and practices, present mission strategies have encouraged Christian witnesses to the need for guiding new believers from other cultural orientations to practice faith in biblical ways that are appropriate to their culture.

\section{Critical Contextualization}

Of the commonly identified and applied models that address culture and mission, ${ }^{45}$ the critical contextualization model describes a superior approach for bridging

\footnotetext{
${ }^{44}$ Scott A. Moreau, Contextualization in World Missions: Mapping and Assessing Evangelical Models (Grand Rapids, MI: Kregel Academic, 2012), 36.

${ }^{45}$ Dean S. Gilliland, "Contextualization," Evangelical Dictionary of World Religions (Grand Rapids, MI: Baker Books, 2000), 227. Some of the models include: (1) adaptation, which emphasizes Western traditional ideas as the norm for Christianity for all cultures; (2) the anthropological model, that underscores the validity of all cultural forms as vehicles of truth; (3) the critical model, which supports scrutiny of culture and Scripture with the goal of finding new ways for expressing faith and practice; (4) the semiotic model, which seeks to connect church tradition and culture; (5) the synthetic model, which
} 
the tension and gap that often exist between culture and the gospel. Paul Hiebert's four cardinal steps contained in this process underscore the necessity of allowing believers to have a voice in how they practice faith within their settings or biblically respond to culture-related issues. $^{46}$

Benefits of the critical model of contextualization are numerous. The model helps to define the role of the missionary in cross-cultural witnessing. Rather than being viewed as a destroyer of culture or an imposer of foreign ideology, ${ }^{47}$ the Bible worker primarily functions as a facilitator in the learning process rather than prescribing of what should be done. Hiebert states that "the missionary may not always agree with the choices the people make, but it is important, as far as conscience allows, to accept the decisions of the local Christians and to recognize that they, too, are led by the Spirit of God."48 Apart from defining the role of the missionary and that of the congregation, the contextual approach also ensures that the gospel is proclaimed to all people without any kind of hindrances or barriers. The apostle Paul exemplifies this when declares,

Though I am free and belong to no one, I have made myself a slave to everyone, to win as many as possible. To the Jews I became like a Jew, to win the Jews. To those

combines the gospel, Christian tradition, culture, and social change, thereby validating all four as equal sources of truth; and (6) the translation model, which emphasizes originality of biblical forms as the norm for all Christian practice.

${ }^{46}$ Hiebert, Anthropological Insights for Missionaries, 186-187. Foremost among the steps is for a congregation at a particular locality to deal with culture-related issues. During challenging occasions such as birth, sickness, and death, when people are often prone to seek for answers or make responses, Christians have to critique what their culture proposes in-light of biblical revelation. In the second step, the congregation examines traditional beliefs and practices. This allows people to investigate deeper worldview assumptions that are unconsciously held and also to find out why they do what they do. The third step requires gospel practitioners to guide the church in examining the Scripture to establish the will of God. By facilitating bible study sessions and seminars, the missionaries guides believers to find biblical truth for the various situations in which they find themselves. The fourth step is mainly decision-making. Believers choose how to deal with their cultural issues in-light of what is revealed to them in Scripture.

${ }^{47}$ Stephen B. Bevans, Mission \& Culture: The Louis J. Luzbetak Lectures (Maryknoll, NY: Orbis Books, 2012), 67.

${ }^{48}$ Ibid., 190. 
under the law I became like one under the law (though I myself am not under the law), so as to win those under the law. To those not having the law I became like one not having the law (though I am not free from God's law but am under Christ's law), so as to win those not having the law. To the weak I became weak, to win the weak. I have become all things to all people so that by all possible means I might save some. I do all this for the sake of the gospel, that I may share in its blessings (1 Cor 9:19-23).

\section{A Contextualized Ministry for Nomads}

The need for contextualizing Christian ministry in nomadic contexts cannot be over emphasized. As previously discussed, nomads often reject Christian influences primarily because the Christian forms regularly presented are foreign and out of touch with the nomads' socio-cultural reality. Gideon Petersen observes that often times the Christian message to nomads arrives "pre-packaged" with Westernization-a written text (the Bible), a church (a building or meeting place), and a congregation (a new social structure) among other packaged items. ${ }^{49}$ Such approaches that disregard the nomads' cultural realities render the gospel of less value and even entirely irrelevant. ${ }^{50}$

Missiologists and missionaries to nomadic groups agree that a contextualized ministry for nomads should engage three main Christian life areas among others. These include a nomadic theology, a nomadic pastoral ministry, and a nomadic church structure.

\footnotetext{
49 Petersen, "Ministry to Nomads," 21.

${ }^{50}$ Michael Frost and Alan Hirsch, The Shaping of Things to Come: Innovation and Mission for the 21st-Century Church (Grand Rapids, MI: Baker Books, 2013).
} 


\section{A Contextualized Theology}

Although Scripture is a revelation of God containing everlasting truths for all ages and cultures, it nevertheless speaks to particular people in particular times ${ }^{51}$ This claim poses pertinent implications for cross-cultural mission where people from diverse sociocultural realities expect to hear the gospel message and apply Scripture within their own culture. A contextualized theology for nomads will involve self-theologizing. ${ }^{52}$

The self-theologizing principle is a mandate for every established congregation and challenges Christians to make theology their own concern. The principle calls upon each church, through a faithful study of Scripture, to respond biblically to cultural issues and faith challenges raised by its people. ${ }^{53}$ In the case of nomads, self-theologizing should include developing a hermeneutical strategy to assist in the interpretation of Scripture in light of their context. ${ }^{54}$ This step is necessary to allow pastoralists to understand and find relevancy in the Word of God—ethnohermeneutics. ${ }^{55}$ David Phillips argues that developing an interpretive strategy of Scripture for nomads does not lead to a

${ }^{51} \mathrm{~J}$. Todd Billings, The Word of God for the People of God: An Entryway to the Theological Interpretation of Scripture (Grand Rapids, MI: Eerdmans, 2010), 57-58.

${ }^{52}$ Hiebert, Anthropological Insights for Missionaries, 214-216.

${ }^{53}$ Ibid. Specific worldview themes such as the quest for salvation, death and life beyond, the reality of the human condition, God's promises, how to relate with the "spirit world" (God, spirits, demons), the importance of initiation rites, and God's advocacy for justice, community life, and morality, responsible living, are common and should be the focus in the development of hermeneutical strategies for the Pokot. See, Zablon Nthamburi and Douglas Waruta, "Biblical Hermeneutics in African Instituted Churches," in The Bible in African Christianity: Essays in Biblical Theology, ed. H. W. Kinoti and J. M. Waliggo (Nairobi, Kenya: Acton, 1997), 55-56.

${ }^{54}$ For an example of a biblical hermeneutics for a nomadic group, see David J. Ndegwah, Biblical Hermeneutics as a Tool for Inculturation in Africa: A Case Study of the Pokot People of Kenya (Charlotte, NC: Creations Enterprises, 2007).

${ }^{55}$ Rogers, The Role of Worldview, 128. 
different message but to an essential reinterpretation of "our knowledge of the Bible by a rediscovery of the Bible's own emphasis on being travelers and pastoralists and seeing God as our herdsman and shepherd. This implies thinking like nomads and seeing the Bible from their perspective, a practice which is wholly biblical. ${ }^{556}$

The development of hermeneutics for nomadic contexts should also include Bible study programs that are adaptable to nomads' needs and challenges so that they find the Good News to be deeply relevant and helpful. ${ }^{57}$ In place of an abstract presentation, teaching, and interpretation of biblical texts that is often used to reach other people, an approach that examines Scriptures holistically should be adopted.

\section{Training Nomadic Theologians and Pastors}

The training of theologians and pastors from and for nomadic contexts is fundamental for enhancing the work of God among nomads and missionaries should endeavor to make this a priority. As cultural insiders, local theologians and pastors are better suited to wrestle with issues arising from their culture rather than depending on explanations from missionaries coming from outside. ${ }^{58}$ Apart from being key to mission ownership once missionaries leave the area, locally trained church workers are also more helpful in advancing faith in their own community and beyond. Their love for God and exemplary commitment is likely to lead people to develop an appreciation of God as their creator and savior, just as $\mathrm{He}$ is to the settled people. For workers coming from outside, a

\footnotetext{
${ }^{56}$ David J. Phillips, “The Need for a Nomadic Theology (Part One)," International Journal of Frontier Missions 17, no 2 (Summer 2000).

${ }^{57}$ Ibid.

${ }^{58}$ Hiebert, Anthropological Insights for Missionaries, 215-216.
} 
specialized orientation that often lacks in regular seminary training is required. ${ }^{59}$ While qualities such as love for adventure flexibility to experience a nomadic lifestyle are necessary, a deeper curriculum that will assist theologians and pastors is important. This should assist workers to find biblical themes, discipleship, and church models that are relevant to people, gain skills in oral communication to enable appropriate sharing of the gospel, and develop strategies for fostering close relationship with nomads in order to gain their trust among other gains. ${ }^{60}$

\section{Nomadic Churches}

Traditionally, Christianity has been centered around permanent structures for routine weekly worship as it arose within Western civilizations. However, evangelistic efforts to nomadic people have opened new frontiers, challenging mission stakeholders to rethink the church structure. Although some mission funding agencies and churches still prefer the construction of Western forms of church in nomadic contexts, ${ }^{61}$ these efforts are viewed as stumbling blocks for ministry among nomads and confirm their view that Christianity is a religion of settled people. ${ }^{62}$

${ }^{59}$ David J. Phillips, "Factors in Training Workers for Nomadic Peoples," International Journal of Frontier Missions 17, no. 3 (Fall 2000), 41.

${ }^{60}$ Phillips, "Factors in Training Workers," 41-43.

${ }^{61}$ David J. Phillips, "Striking Camp with Nomads," Mission Frontiers, accessed December 3, 2016, http://www.missionfrontiers.org/issue/article/striking-camp-with-the-nomads?from_navigate=true.

${ }^{62}$ Ibid. The construction of buildings for worship meetings can be the cause of stalled work among nomads. Such buildings might be ignored, distort understanding, or destroy the nomadic cycle, thereby disrupting the nomads' way of life. This also demonstrates the workers' ignorance of the value of nomadism to the people being reached. 
These frustrations with Western forms of church are expressed in the famous comment of a Somali nomad to Malcolm Hunter when he said,

When you can put your church on the back of a camel, then I will think that Christianity is meant for us Somalis. I am a Muslim because we can pray anywhere, five times a day, every day. We only see you Christians praying once a week, inside a special building, when one man stands in front and talks to God while everybody else hangs their heads and looks to be falling asleep. ${ }^{63}$

Some of the suggestions regarding a nomadic church include Petersen's Abrahamic model of worship, which emphasizes family worship that is centered on the father as the teacher of God's will. ${ }^{64}$ Because of the strong social ties that characterize most nomadic societies, ${ }^{65}$ the Abrahamic model endorses the fact that religion is better practiced every day and at any time within family circles than at appointed times such as the Sabbath days, or at specific locations such as church buildings. This leaves the question of how to incorporate larger gatherings.

Hunter suggests that since nomads are already used to a social life that may consist of close contact with only two or three companions for long periods of the time, developing personal relationships is preferable to establishing larger organizations. Nomads' larger gatherings involving religious observances and extended family rites of

\footnotetext{
${ }^{63}$ Malcolm J. Hunter, "The Nomadic Church: The Church in Its Simplest Form." International Journal of Frontier Missions 17, no. 3 (Fall 2000), 16.

${ }^{64}$ Petersen, "Ministry to Nomads," 99.

${ }^{65}$ Craig Ott and Gene Wilson, Global Church Planting: Biblical Principles and Best Practices for Multiplicity (Grand Rapids, MI: Baker Books, 2011), 102. Both authors argue that the social strength in nomadic societies needs to be the foundation of the church for nomads. Instead of focusing on individual conversion, transformation of families or groups should be encouraged, until a sufficient number has been reached to establish a broader congregation.
} 
passage (such as circumcisions, sapana, and weddings) could become models for occasional larger congregational meetings. ${ }^{66}$

The annual camp-meeting session common within Adventism can also be considered as an option for the larger periodic gathering of believers from nomadic backgrounds. ${ }^{67}$ These meetings can be used to encourage nomads to evangelize fellow nomads and also for reporting on the progress of mission among the community. ${ }^{68}$

\section{Communicating with Nomads}

Communication plays a key role in missions. ${ }^{69}$ Together with other social sciences, communication contributes to the discipline of missiology, which deals with the deep analysis of cultures to enable a thorough understanding of a community. This understanding aids in the appropriate and relevant communication of the gospel. ${ }^{70}$

\section{Foundations of Christian Communication}

The foundation of Christian communication is based on God's character of being a communicating God. From the beginning, and through various means, God has sought to connect with humanity, seeking to re-establish a relationship, which was broken by sin.

${ }^{66}$ Hunter, "The Nomadic Church."

${ }^{67}$ Petersen, "Ministry to Nomads," 99-100.

${ }^{68}$ During the research, it was noted that camp-meetings for nomads are already taking place among other pastoralists in the Rift-valley. This development could be adopted in Pokot as well since the groups share a similar wandering life-style.

${ }^{69}$ Edward Rommen and Gary Corwin, Missiology and the Social Sciences (Pasadena, CA: William Carey Library, 1996), 10. According to these authors, missiology is the branch of theology that is by definition inclusive of the social sciences.

${ }^{70}$ McGavran, Understanding Church Growth, 265. 
God's divine love, will, purposes, and promises of reuniting with humanity, enabled by the salvation plan, are all messages that have been and continue to be conveyed. ${ }^{71}$

Paul writes that "in the past God spoke to our forefathers through the prophets at many times and in various ways, but in these last days he has spoken to us by his Son, whom he appointed heir of all things, and through whom he made the universe" (Heb 1:1-2). God also communicated through other means such as dreams (Gen 46:2; Dan 10; Joel 2:17; Matt 1:21; 2:13), visions (Amos 3:7; Acts 2:17), fire (Amos 1:10; Acts 2:13), and through nature—birds (Gen 8:6-8, 1 Kgs 17:6-8, Matt 26: 36, 75), animals (Num 22:21-33), and a burning bush (Exod 3:1-4:17). ${ }^{72}$

The various methods God uses to communicate with the world signify that there is no limitation to the ways through which God's will is revealed to humans. Divine plans can be found in the written word, dream, and stories, as well as in music. This also implies that God is considerate of human situations.

\section{Challenges of Effective Communication}

Effective communication of the gospel cross-culturally is a continual task for Christian mission. ${ }^{73}$ This challenge arises primarily because of cultural differences in understanding, interpretation, and responses that tend to vary from one group to another. It is widely known that within the human context, there exist broad social gaps and

\footnotetext{
${ }^{71}$ Kraft, Communication Theory for Christian Witness, 11-22.

${ }^{72}$ William A. Dyrness and Veli-Matti Kärkkäinen, eds., Global Dictionary of Theology: A Resource for the Worldwide Church (Downers Grove, IL: InterVarsity, 2008), 241-242.

${ }^{73}$ Van Rheenan, Missions, 32.
} 
variances, such as gender, social class, age, educational background, occupation, subculture, and dialect. ${ }^{74}$

A great majority of the world's Christian workers come from literate cultures and tend to present the gospel using alien and highly literate communication strategies. ${ }^{75}$ In the context of nomadic communities, Christian groups have traditionally employed public evangelism as the main method of sharing the gospel. This approach involves abstract presentation of Christian teachings through the use of illustrations and modern technology, which are often foreign to these groups. ${ }^{76}$ As Carlos A. Valle points out, Whoever is the receiver of the message is not taken into account. His socio-cultural conditions are not a determining factor. The meaning of sin, the concept of peace, freedom, and salvation is accompanied by the same prescription no matter whether he lives in the country or the city. It does not matter whether he/she is young or old from Switzerland or Angola. ${ }^{77}$

This approach is one of the reasons why nomads such as the Pokot have persistently responded negatively to Christian influences, since the methods used undermine their cultural ways of life and worldviews. ${ }^{78}$

${ }^{74}$ Kraft, Communication Theory, vii.

75 International Orality Network, "Making Disciples of Oral Leaners," in Perspectives on the World Christian Movement, 4th ed., ed. Ralph D. Winter and Steven C. Hawthorne (Pasadena, CA: William Carey Library, 2009), 437.

76 The target groups are invited to public meetings where preachers use loud public address systems to present messages and invite people individually to commit their lives to Jesus. In most cases, people respond not so much because they are convinced of the message but because of the noise and confusion that accompany the event. After the public campaign, most converts revert to their old ways of life, proving that effective communication did not occur.

${ }^{77}$ Carlos A. Valle, Challenges of Communication (Delhi, India: ISPCK Press, 1995), 14.

${ }^{78}$ Hunter, "Think Nomadic," 9-13. 
In spite of these differences, the gospel has to be communicated to all people groups in ways that will benefit the hearers in their settings. This is enabled by the development of various theories and principles that guide effective cross-cultural witnessing.

Notable is the "Three Culture Model of Missionary Communication" by Eugene A. Nida. ${ }^{79}$ His proposal suggests that missionaries should understand the Bible culture, the sender's culture, and the respondent's culture in order to complete the cycle of communication. The Three Culture Model is generally effective since it accounts for cultural differences between the messenger and the respondent. ${ }^{80}$ The model also requires missionaries to exegete the target culture, uncovering their methods of communication to enable mission workers to relay the gospel in familiar ways so their targeted people can understand. ${ }^{81}$

Similar to the Three Culture Model is a proposal by Valle to intentionally seek an understanding of the owner of information (God), the content of the message (the gospel), and receiver of the message (humans). ${ }^{82}$ Additionally, David J. Hesselgrave expresses the need to explore the role of culture in communication by examining the

${ }^{79}$ Nida, God's Word.

${ }^{80}$ Sean S. O'Neal, Bridges to People: Communicating Jesus to People and Growing Missionary Churches in a Multi-Ethnic World (Maitland, FL: Xulon Press, 2007), 156.

${ }^{81}$ Hiebert, Gospel in Human Contexts, 12.

${ }^{82}$ Valle, Challenges of Communication, 10-15. 
challenge cultural diversity poses to evangelism. ${ }^{83} \mathrm{He}$ writes that the missionary must look at two other cultures other than one's own when communicating the gospel. ${ }^{84}$ These fundamental theories that guide effectiveness in communicating the gospel bring to the fore key principles that are applicable for SDA witness among nomadic peoples.

First, communication of the gospel ought to be incarnated. The incarnational model for cross-cultural communication challenges ministers to study the language, culture, values, and ethics of the respondent community and be able to adapt and employ these in conveying the gospel. George A. Phiri's comment on the incarnation models of Christ and Apostle Paul affirms,

The gospel though important and significant as it is, will not be relevant and make any impact to any people unless incarnated into the culture of the respondent society. Just as Jesus Christ became relevant to the Jewish society through incarnation and Apostle Paul to the gentiles, so should the church planter and a missionary be in Africa. Both Christ and Paul studied and learnt the beliefs, values, rituals, language, and culture of his immediate society in order to communicate the message of salvation. Christ did not bring into the world from heaven the language or culture... They (Christ and Paul) learned and adapted beliefs and value systems, culture, language, food, ethics, and morals of their immediate societies. A church planter ought not to import his culture into the missionary field. ${ }^{85}$

Employing the respondents' valued communication methods, symbols, and objects means that God speaks directly to people in a manner they are familiar with. It is imperative that missionaries to nomads take time to study the songs, parables, proverbs, stories, and sayings, which nomads are already accustomed to and use these in ministry

${ }^{83}$ David J. Hesselgrave, "The Role of Culture in Communication," in Perspectives on the World Christian Movement, ed. Ralph D. Winter and Steven C. Hawthorne (Pasadena, CA: William Carey Library, 2009), 425-429.

${ }^{84}$ Ibid, 425.

${ }^{85}$ Phiri, Social-Cultural Anthropology, 34-35. 
rather than imposing unfamiliar methods. If applied among nomads, the incarnational model for communication is likely to produce a positive response to the gospel message.

Second, Christian witness should be mindful and respectful of social structures. This principle is most critical when ministering outside of one's cultural background, where socio-political leadership roles are defined differently from that of the missionary or even Scripture. ${ }^{86}$ John Apeh admonishes,

Before a mission advances its organizational methods and principles, a study of the people and their leadership pattern is warranted. Organizing believers into a local congregation necessitates the selection and appointment of leaders. The steps taken to install a culturally and biblically based leadership must be in agreement with the practices of one's receptors. ${ }^{87}$

The need to be attentive to people's social structures is imperative when evangelizing nomads. Groups such as the Pokot, although based on a decentralized power system, ${ }^{88}$ still value and recognize the authority of elders and respects them as the spokespersons of the community. In such contexts, the sharing of the gospel should begin with the elders, who are mandated to make decisions for the rest of the society. At the very least, missionaries should seek to notify and seek the approval of the elders about evangelistic activities in the community.

${ }^{86}$ Paul's admonition for the Corinthian women believers to be silent during worship services (1 Cor 14:34) is indicative of the fact that the local culture has significant influence over how a congregation operates. In those societies where community leadership is primarily the responsibility of elderly men, appointing women to lead a church congregation composed of men who are capable leaders may produce negative responses from the larger community.

${ }^{87}$ John E. Apeh, Social Structures and Church Planting (Shippensburg, PA: Companion, 1989), 8.

${ }^{88}$ Bollig, "Staging Social Structures." 


\section{Nomads and Orality}

Orality is central to communication in nomadic communities. The concept, which has been studied extensively by Walter J. Ong, is built on the notion that among oral communicators, sounds play a key role in the transmission and retention of information. Paul Hiebert also writes that in most societies, sounds signify power and are sacred. "To say the right sounds is to cause things to happen. The right sounds can cause rain to fall. Other oral sounds such as drumming and shouting protect people from evil spirits." 89

Additional significant elements in orality include the significance of the human voice. ${ }^{90}$ In reference to African societies, Vincent Kituku explains that, the human voice is the vehicle through which knowledge is passed on from one generation to another. In the past, "voice unified a family, a clan, or a community. Enforcement of customs depended on voice. When a person died, his or her voice was no longer to be heard; it was as if a whole library had been destroyed." $" 91$

Transmission of knowledge is possible through oral methods. In oral societies, learners carry with them what they know through stories, proverbs or mental pictures of life events, which they can remember and use as necessary when facing adversity. They depend on their memory for understanding. They often have a remarkable ability to memorize long stories and treasure them, since these stories are perceived as authoritative

${ }^{89}$ Hiebert, Transforming Worldviews, 116.

${ }^{90}$ Sharon Wilson, “African Oral Tradition,” accessed March 17, 2016, http://www .blackandchristian.com/articles/academy/swilson-09-03.shtml. See also Walter J. Ong, "World as View and World as Event," American Anthropologist 71, no. 4 (November 1969): 641-643; Hiebert, Transforming Worldviews, 115.

${ }^{91}$ Vincent Muli wa Kituku, East African Folktales: From the Voice of Mukamba (Little Rock, AR: August House, 1997), 11. 
or a significant component of one's heritage. ${ }^{92}$ Knowledge in the form of stories, parables, songs, aphorisms, proverbs, riddles, poems, and creeds, which can be easily remembered, are also stored in rituals.

An outstanding feature of oral communication is its highly relational nature. For the most part, orality takes place in specific contexts with a particular audience or person and focuses on certain messages. Aside from information, other messages, such as feelings and moral judgment are also conveyed through oral and physical methods, through tone of voice, gestures, facial expressions, and standing distance. Active listening and long-term memory are expected. This relational aspect of oral language explains why oral communicators tend to learn together communally. They depend a great deal upon the feelings and opinions of peers, valuing shared beliefs.

Since the Pokot and other Kenyan pastoralists are primarily oral communicators, ${ }^{93}$ whose principal method of storing and relating information or teaching cultural values is through oral means, it is imperative that missionaries rely on the nomads' oral methods of communication to convey the gospel in their heart language.

${ }^{92}$ Ibid.

${ }^{93}$ Evans, "Communicating Christ." Oral cultures are centered in the practice of storytelling. It is their primary means of communication. They prefer these integrative ways of learning rather than the fragmented, analytical approaches that are common in contemporary education. Western-style education emphasizes analysis - breaking things apart and focusing on extracted principles. Oral communicators prefer holistic learning, keeping principles embedded in the narratives that transmit them. Oral communicators learn better through the concrete, relational world of narratives than they do through the abstract, propositional framework of Western educational systems. Both learning approaches deal with propositional truth, but oral communicators keep the propositions closely tied to the events in which those truths emerged. People who are steeped in literacy can more easily detach the propositions and deal with them as abstract ideas. In both cases people are learning "truth," but the way the truth is packaged and presented differs dramatically. 


\section{Proverbs}

Proverbs and sayings are important oral means of communication through which the gospel can be shared among pastoralists. The use of proverbs to convey God's message has a long history. Old Testament wisdom literature books such as Job, Proverbs, Ecclesiastes, and Songs of Solomon contain God's message in the form of proverbs and sayings to the people of Israel. Christ's own ministry was influenced by Jewish wisdom traditions. He often quoted proverbs and used parables and sayings to present the gospel to His audience demonstrating that these are valid methods of communicating biblical truths. ${ }^{94}$

In African communities, proverbs and sayings are traditionally useful techniques for teaching values and promoting virtuous living. ${ }^{95}$ Most tribal groups utilize proverbs to teach, rebuke, shame, or caution the youth against unscrupulous behavior or straying from moral paths. ${ }^{96}$ This is evident among the Pokot, where proverbs and sayings illustrate vital life lessons. Proverbs are quoted either privately or publicly to instruct young people or during the elders councils when settling disputes. In the kokwo, the elders' council, these methods are mostly used to demonstrate a point rather than to teach.

Since proverbs and sayings are significant means of communication among nomads, missionaries should tap into the community's proverbs to relay the gospel. Apart 267.

${ }^{94}$ Donald J. Goergen, The Mission and Ministry of Jesus (Eugene, OR: Wipf and Stock, 2003),

${ }^{95}$ Hesselgrave, Communicating Christ Cross-Culturally, 327.

${ }^{96}$ Hiebert, Transforming Worldviews, 105-122; Petersen, "God Speaks,” 98-109; Gideon, Petersen, “Training Oral Leaders: An Adventist Challenge.” Journal of Adventist Mission Studies 5, no. 2 (Fall 2009): 86-96. 
from aiding an understanding of the culture and traditional religion of those targeted, proverbs also assist in the interpretation of Scripture in a culturally relevant way, thus contributing to the contextualization process. ${ }^{97}$

\section{Media}

International organizations and other groups in collaboration with the government have developed other contextual strategies to communicate with pastoralists. An educational strategy called The Distant Learning Approach, instituted by the International Institute for Environment and Development in conjunction with the Ministry of State for the Development of Northern Kenya and other Arid Lands, ${ }^{98}$ advocates using radio to assist nomads in acquiring the education and skills needed to compete with the rest of society, without abandoning their nomadic life.

This program is focused on reversing the current disparity in education between pastoral nomads and the rest of the Kenyan people. It has piloted innovative distance learning approaches using radio and communication technology in isolated nomadic communities and has developed strategies that allow nomadic children and their families to access education. This eradicates the need for nomadic people to choose between getting an education and herding.

Similar usage is witnessed among mission workers. The Catholic mission of Marsabit County is currently using wireless radios to reach the pastoralist population in

\footnotetext{
${ }^{97}$ W. Jay Moon, African Proverbs Reveal Christianity in Culture: A Narrative Portrayal of Builsa Proverbs Contextualizing Christianity in Ghana (Eugene, OR: Pickwick, 2009), 3-4.

98 "Education for Nomads," International Institute for Environment and Development, accessed December 19, 2016, http://www.iied.org/education-for-nomads.
} 
the area. It is reported that Eugene Blaj, who is the head of the Maikona Parish, is reaching the local population with radio services. ${ }^{99}$ Films, cassettes, and other recorded messages are also used by organizations trying to reach pastoralists.

Because of poor and seasonal roads that impede accessibility to pastoral regions, reaching nomads is a challenge. Consequently, the government and some organizations have resolved to use radio broadcasts and taped messages to reach pastoralists. ${ }^{100}$ Positive mail responses to these broadcasts indicate some degree of success. The SDA Church must study and implement ways in which the unique message of the gospel can be shared through the radio, taped cassettes, and films. ${ }^{101}$

\section{Storytelling}

The significance of using stories when sharing the gospel is far reaching. Because of the communicative qualities associated with stories, they would also be beneficial in witnessing to nomads.

Stories are advantageous because they are a universal form of communication. ${ }^{102}$ They are popularly employed not only in oral contexts but also among literate cultures. It is estimated that more than half of the world's population prefer using stories in the

\footnotetext{
99 "Kenya: Missionary Starts Radio Communication with Nomads," All Africa, accessed November 13, 2016, http://allafrica.com/stories/200409240854.html.

${ }^{100}$ Office of the Prime Minister, "Getting to the Hardest-to-teach: A Strategy to Provide Education to Nomadic Communities in Kenya," accessed September 15, 2016, http://pubs.iied.org/pdfs/G02742.pdf. See also, David Siele, Jeremy Swift, and Saverio Krätli, "Reaching Pastoralists with Formal Education: A Distance Learning Strategy for Kenya" (paper presented at the International Conference on the Future of Pastoralism, Tufts University, MA, March 21-23, 2011).

${ }^{101}$ See further recommendations by Phillips, Peoples on the Move, 124.

${ }^{102}$ Steffen, "Why Communicate the Gospel," 441.
} 
process of learning. ${ }^{103}$ This is evidently true across academic disciplines where, because stories have the inherent power to capture the attention of the audience and connect with imagination and emotions, ${ }^{104}$ they are used widely to propagate ideas. ${ }^{105}$

For Christian witnesses, the use of stories is vital because seventy-five percent of the Bible is narrative. ${ }^{106}$ The Old Testament captures stories of the creation, the fall, the flood, the patriarchs, the prophets, the call of Abraham, and the Israelites, among others. In the New Testament stories about the birth and ministry of Jesus, who widely used stories to teach, ${ }^{107}$ the disciples, the Early Church, and about the second coming of Jesus are included. As an essential tool for teaching religious dogmas, other major religions also use stories to socialize its young, convert potential followers, and indoctrinate members.

Stories are also useful in ministry because they create instant evangelists. ${ }^{108}$ People often retell interesting stories they have heard if they are funny, interesting, or when sharing ideas. Most of the people Jesus healed went out telling what Jesus had done

103 Ibid.

${ }^{104}$ Steffen, "Why Communicate the Gospel," 441.

105 Jennifer A. Moon, Using Story to Enrich Learning and Teaching: In Higher Education and Professional Development (New York: Routledge, 2010), 8-9.

106 Steffen, "Why Communicate the Gospel," 441.

${ }^{107}$ Ibid., 443.

${ }^{108}$ Ibid., 440. 
to them and in some cases people came looking for the Savior based on what they heard. ${ }^{109}$

In the context of Africa, stories enable people to understand concrete concepts such as God, sin, and redemption with ease. The acts of God and His dealings with humanity are unfolded with clearer understanding through frequently narrated stories. ${ }^{110}$ Commenting on their impact on African religiosity, Joseph G. Healey writes that, "African stories have always been privileged places of God's revelation. The proverbs and myths of African people reveal that the Holy Spirit sowed seeds of the good news in African cultures long before the African people ever heard of Jesus' words and teachings."111

Since oral communicators tend to describe people by telling stories about them, ${ }^{112}$ pastoralists are likely to learn about God and Jesus by hearing stories, which describe and speak about them. Other stories which might appeal to nomads include stories of God's community - the Church, the second coming of Jesus, and the final destruction of sin.

Stories are also helpful in worldview transformation. The art of telling and listening to stories helps to reveal worldviews as people narrate insights of their beliefs and assumptions and the reasons why they act the way they do. Because people develop worldviews from childhood as they interact with society, stories often told in a

\footnotetext{
${ }^{109}$ See examples of the woman at the well (John 4:1-30), healing of a blind man (John 9), and healing of a man with unclean spirit (Mark 5:1-20).

110 Joseph G. Healey, African Stories for Preachers and Teachers (Nairobi, Kenya: Paulines Publications Africa, 2005), 153.

${ }^{111}$ Ibid.

${ }^{112}$ Samuel Poe, "Bringing the Good News to Oral Cultures," accessed November 2, 2016, http://www.newfrontierschurch.com/downloads/cbs/oralcultures.pdf.
} 
community help to construct their worldview. In a similar manner, it is also through telling of new stories which challenge older views that worldview can be changed.

In order for stories to impact nomads, skillful storytelling is essential. The Chronological Bible Storytelling strategy has often been used to communicate the gospel in oral contexts. Since the concept of time among oral communicators is viewed as the present with the incorporation of both the past and future, ${ }^{113}$ telling key stories of the Bible in chronological order will help pastoralists, who depend upon memory, to retain what they have learned and to remember life experiences through the lens of the stories they have heard. ${ }^{114}$ With the gospel then put to memory, new believers can continue to tell others the story, thus becoming disciples themselves. ${ }^{115}$

The chronological approach, which follows the story of the fall, the call of Abraham, and the Old Testament sacrificial system and its promises of redemption, helps to construct a biblically-shaped worldview. ${ }^{116}$ This approach is helpful for linking scriptures together, forming one overarching story rather than isolated abstract topics, as is often the case in modern evangelism. This assists the hearers in beginning to understand each individual story in the context of God's Big Story. ${ }^{117}$ Such an approach

${ }^{113}$ Hiebert, Transforming Worldviews, 115.

114 Poe, "Bringing the Good News."

115 Ibid.

${ }^{116}$ David J. Hesselgrave, Planting Churches Cross-Culturally: North America and Beyond (Grand Rapids, MI: Baker Books, 2000), 145.

117 Trevor McIlwain, Firm Foundations: From Creation to Christ (Sanford, FL: New Tribes Mission, 2009). 
will also help avoid the blending of individual biblical stories or truths with conflicting worldview assumptions held within the hearers' own cultural stories and experience.

In addition, Chronological Biblical Storytelling fosters a sense of community by uniting the story-teller and the listeners. ${ }^{118}$ Close relationships arise through telling and listening to one another's stories. In this way, trust between the missionary and the audience is developed. Effective proclamation of the gospel through story telling will require missionaries to be good storytellers and to be able to engage the community in a relational way by dialoguing and listening to their stories as well. ${ }^{119}$

\section{Songs}

Songs are key biblical as well as cultural methods of communication. In Scripture, entire books such as Psalms are musical expressions of God's love and promises for protection, provision, and salvation for His people. The song texts also appeal to people to praise, exalt, and worship God for His faithfulness and assuring promises (Exod 15:121; 2 Chr 5:13; Ps 71:23; 95:1; 98:1-7; 105:1-5). Other potions of Scriptures contain songs of emotional petitions and prayers for deliverance and thanksgiving for God's mercy when people faced trying moments (Exod 15:1-21; Ps 32:7; 2 Sam 22). In addition, believers are encouraged to comfort, teach, and cheer each other through singing (Eph 5:19; Col 3:6).

As cultural tools of communication, songs are useful for the formation and preservation of a culture. Anthony Seeger observes that for a community to maintain its

\footnotetext{
118 J. O. Terry, "Chronological Bible Storying to Tribal and Nomadic Peoples," International Journal of Frontier Missions 14, no. 4 (Fall 1997): 6.

119 Moon, "Eyes of Oral Learners."
} 
identity, motivate its members to work together, struggle for common goals, or resist outside influences in order to create and maintain future of their own design, deep-seated bonds forged through the senses play a significant role. Even though music is popularly associated with leisure and entertainment, a community's repetitive music sounds help to create its cultural identity and to erase the identity of outsiders. ${ }^{120}$

They also play a key role in the transmission of information when teaching, counselling, and warning. Songs also inspire people during their celebrations, when conducting rituals, or when going to war. Among pastoralists such as the Borana, every aspect of culture is captured in song and handed down from one generation to the next. Children are educated and acculturated through music. ${ }^{121}$ The celebrations of rites of passage or victory against enemies are accompanied by song and dance.

The use of songs when sharing the gospel among nomads will be beneficial in many ways. In her argument for why songs matter, Miriam Adeney notes that songs are much faster and accurate tools for teaching biblical truths to oral communicators compared to other methods. She quotes Viggo Søgaard's experience with Buddhist converts indicating that oral communicators can learn up to twenty new songs in a week with no major effort if these were played over and over. ${ }^{122}$ This means that if biblical

\footnotetext{
${ }^{120}$ Anthony Seeger, "Traditional Music in Community Life: Aspects of Performance, Recordings, and Preservation," Cultural Survival Quarterly Magazine (December 1996).

${ }^{121}$ Francis Omondi and Orvill Boyd Jenkins, "The Borana of Ethiopia and Kenya," Strategy Reader Resource Kit, accessed July 1, 2016, http://strategyleader.org/profiles/borana.html.

${ }^{122}$ Miriam Adeney, "Feeding Giraffes, Counting Cows, and Missing True Learners: The Challenge of Buddhist Oral Communicators," in Communicating Christ Through Story and Song: Orality in Buddhist Contexts, ed. Paul H. De Neui (Pasadena, CA: William Carey Library 2008), 101-102.
} 
texts were committed to songs, people from an oral background will learn much more easily than if they were taught through literary means.

Repetitive singing is advantageous in two main ways: memorization and accuracy. The melody accompanying songs often act as a mnemonic device assisting in the memorization of the messages. ${ }^{123}$ Repeated singing also ensures accuracy of information. While other methods of teaching allow a speaker's additions to a text (a major cause of biblical distortion), rhythm and melody in song ensures stability of a text through faithful and accurate transmission. ${ }^{124}$ Information repeatedly sung can be easily remembered and any change detected or resisted. ${ }^{125}$

Songs also address fundamental worldview questions thereby assisting in its transformation. Nathan J. Corbitt states that "music is theological. It talks about God and our relationship to Him and our world, and answers one basic question: what is the good life and how does one attain it?"126 This element of music is fundamental in witnessing since the ultimate goal for sharing the gospel is having transformation of worldviews. Music can also assist in providing a meaningful interpretation of concepts that are difficult to understand for believers from oral regions. Although other oral methods can help in explaining major Christian concepts, music and song often "pave a pathway

\footnotetext{
${ }^{123}$ Ibid., 102; Ivor Calvin Greer, “Orality and Christian Discipleship: Developing A 'Living' Word” (PhD diss., Bangor University, Bangor, Thailand: 2008), 53.

124 Adeney, "Feeding Giraffes, Counting Cows," 102.

${ }^{125}$ Greer, "Orality and Christian Discipleship," 53.

${ }^{126}$ Nathan J. Corbitt, The Sound of the Harvest: Music's Mission in church and Culture (Grand Rapids, MI: Baker Books, 1988), 173.
} 
through the complexity." ${ }^{127}$ Building bridges for relationships and enhancing a sense of community are additional benefits of witnessing through songs. Oswald asserts that song is "frequently the first medium through which people hear the gospel." 128

\section{Redemptive Analogies}

Virtues of strength, bravery, and heroism are aspired and expected among the Pokot. As noted earlier, young people undergo rigorous initiation and training in order to develop these attributes as early as possible. In chapter 4, it was observed that heroic and brave acts of the past are retold to motivate community members to make sacrificial contributions toward the survival of the people. The virtues could serve as a bridge of sharing Jesus, who demonstrates the ultimate virtues of strength, bravery, and heroism.

Among the biblical examples of Jesus' heroism was His selfless and sacrificial life on behalf of humanity to defeat $\sin$ (Mark 10:45, Rom 5:6; 14:15; 1 Thess 5:10; John 10:11; 11:50; 1 Tim 2:6; 1 Peter 2:24). God's names include that of lion or bear, both symbols of strength and bravery (Jer 25:38; 49:19; 50:44; Lam 3:10; Hos 5: 14; 11:10; 13:8). Lion is also used in the Old Testament covenantal relationship between God and His people to reference Christ's redemptive work which culminated in the New Testament (Gen 49: 9-10; Rev5:5). Christ is also depicted in holy writhe as one with power and authority. He is called King of kings or Lord or lords (Deut 10:17, Ps 136:3; I Tim 6:15; Rev 1:5; 17:14; 19:11-16).

\footnotetext{
${ }^{127}$ John Oswald, "Gospel Communication in Tibetan Song," in Communicating Christ Through Story and Song: Orality in Buddhist Contexts, ed. Paul H. De Neui (Pasadena, CA: William Carey Library 2008), 239.

${ }^{128}$ Ibid., 241.
} 


\section{Summary}

Chapter 5 presented a model for mission, focusing on three key missional responses to guide witnessing activities among the Pokot and other Kenyan pastoralists. In this model, transforming the pastoralists' cultural views about origins, God, sin, salvation, and destiny into a biblically-shaped worldview is topmost on the mission agenda. To achieve worldview transformation, mission workers are encouraged to initiate and maintain strong relationships among believers, provide timely and extensive Bible studies and access the cultural tools of storytelling. Once converts achieve the desired transformation, they are likely to safeguard their faith against unbiblical influences, authenticate their faith, and grow into mature Christians able to witness to others.

A second key characteristic of the model is the contextualization of the gospel message. The underlying principle in contextualization is to ensure that the gospel speaks to the pastoralists and allows them practice their faith within their own cultural settings. Through the development of local theologies, training local theologians, and establishing church structures that are relevant to nomadism, pastoralists will be enabled to experience a more personal relationship with God and to respond to the gospel within their own context.

Effective communication is the third principle. The use of oral methods such as proverbs, stories, and songs, with which the pastoralists are familiar, is vital. This enables them to hear and respond to the gospel in their heart language.

The missiological responses discussed in this chapter are fundamental to crosscultural witnessing and foundational to a mission model for SDA witness among Kenya's 
nomadic peoples. Along the same thought, the next chapter explores possible mission strategies that will expedite witnessing in the region. 


\section{CHAPTER 6}

\section{WITNESSING TO THE NOMADS: STRATEGIC RESPONSES}

\section{Introduction}

While prayer and the leading of the Holy Spirit are the primary motivations for carrying out mission-work, developing a working strategy for how to accomplish a specific mission goal is vital and consistent with God's work. Human plans for mission and ministry do not contradict God's ownership of mission but are instead complementary. Jonathan Lewis describes human strategies as "attempts to anticipate the future God wants to bring about." Besides, mission strategies are merely overall approaches, plans, or descriptions of how to go about reaching goals or solving problems. $^{2}$

Even though standard mission strategies can be applied across various contexts, often times specific guidelines help identify the most suitable approaches for a particular mission context. According to Peter Wagner, a mission strategy should be (1) biblically grounded, (2) efficient enough to minimize waste of resources, and (3) relevant to the time and context. ${ }^{3}$ The proposals presented in this chapter have been widely applied in

\footnotetext{
${ }^{1}$ Jonathan Lewis, World Mission: The Biblical: An Analysis of the Christian Movement (Pasadena,
} CA: William Carey Library, 1994), 6-4.

${ }^{2}$ Ibid., 6-8.

${ }^{3}$ Peter C. Wagner, Stop the World: I Want to Get On (Pasadena, CA: William Carey Library 1980), 76-77. 
various contexts, including nomadic regions and are thus likely to effectuate a more systematic witness among Kenya's nomads.

\section{Specialization Strategy}

It is obvious that a congregation is God's primary agent for proclaiming the good news of salvation. ${ }^{4}$ However, mission demands are often times enormous and overwhelm the capabilities of ordinary congregations. The formation of specialized mission structures to support witness beyond what a typical church can accomplish has existed throughout the history of mission. Founded on the concept of the Two Structures of the church, various mission-oriented entities have been instrumental in facilitating witness to unentered and challenging regions. ${ }^{5}$ Advocates of the Two Structure theory, such as Paul E. Pierson, argue that cross-cultural evangelism is rarely done effectively without specialized mission-focused structures. ${ }^{6}$

Supportive evidence for specialized structures of witnessing can be found in Scripture as well as in modern history. Examples of these structures indicate that individuals, independent agencies, and congregation-sponsored organizations are often better equipped, more efficient, and more useful for targeting people in unentered and challenging territories.

\footnotetext{
${ }^{4}$ Ott, Strauss, and Tennent, Encountering Theology, 195-196.
}

${ }^{5}$ For more discussions of the Two Structure theory, see C. Gordon Olson, What in the World Is God Doing: The Essentials of Global Missions: An Introductory Guide (Cedar Knolls, NJ: Global Gospel Publishers, 2003), 313-319; Ott, Strauss, and Tennent, Encountering Theology, 201-214. For a discussion of the same topic within the Adventist Church, see Bruce L. Bauer, "Congregational and Mission Structures and How the Seventh-day Adventist Church Has Related to Them" (D.Miss diss., Fuller Theological Seminary, 1992.

${ }^{6}$ Paul E. Pierson, The Dynamics of Christian Mission: History Through a Missiological Perspective (Pasadena, CA: William Carey, 2009), 40. 


\section{Biblical, Historical, and Contemporary Mandates}

In Scripture, records of individuals who evangelized particular regions and peoples during the early Church era are numerous. The Apostles Paul and Phillip were foremost among many others whose life experiences and sacrifices led them to witness outside of their comfort zones. After persecution commenced in Jerusalem, Philip went down to Samaria and proclaimed the gospel, leading to many conversions (Acts 8:4-13). Paul and Barnabas also travelled from Antioch to new frontiers in the cities of Seleucia, Salamis, Iconium, Lystra, and Derbe (Acts 13:4-14:21). With other companions, Paul later traveled to other Gentile regions, independent of church leadership in Jerusalem or Antioch (Acts 14:27). He and those he worked with managed to support their ministry with tent-making projects (Acts 18:1-4).

At the beginning of the modern missions movement in the nineteenth century, Christian evangelism from the West to foreign lands was spearheaded by mission structures that were mostly composed of lay people convicted that God was calling them to minister to specific culture groups or in specific places. ${ }^{7}$ The formation of mission boards during that era enabled the spread of the gospel in regions beyond the reach of local churches. ${ }^{8}$

In addition to these earlier trends, modern mission work takes place in what is now described as the "era of mission specialization." Most Christian groups are

\footnotetext{
${ }^{7}$ Ibid., 33.

${ }^{8}$ For a comprehensive review of mission agencies in the nineteenth century, see Pierson, The Dynamics of Christian Mission, 32.

${ }^{9}$ Ministry to groups such as Muslims, Hindus, Buddhists, and tribal societies is now common within mission circles.
} 
becoming increasingly focused on particular cultural or social groups in their mission effort. Specialized ministry to groups such as Muslims, Hindus, Buddhists, cities, refugees, immigrants, and tribal societies are now common. These groups utilize distinctive mission methods to reach their targeted people groups. The specialization approach holds a higher potential for success than more generalized mission tactics.

In spite of the important role mission structures play in reaching hard-to-reach groups, SDA ministry to nomads in Kenya still relies on congregational efforts, which are undoubtedly inadequate. ${ }^{10}$ The few independent groups discussed in Chapter 3 are managed by foreign mission agencies that are largely unknown to the local church administration and thus, the work of the two bodies is poorly coordinated. Because these foreign-based groups conduct short-term mission activities without consistent coordination with local churches, they often have limited understanding of nomadic culture due to the short amount of time they spend among the nomads. Since most of the workers live outside of the country, the work often suffers from poor follow-up, inefficient planning, and a lack of financial accountability. ${ }^{11}$

The absence of an SDA organizational structure focused on mission to nomads is problematic. Consequently, the Church should consider developing such an organization to spearhead witnessing activities in the region. The prevalent application of generalized

${ }^{10}$ This study revealed that Adventist churches in close proximity to nomadic regions are expected to witness to the nomads. Although most of the believers in these churches interact with the pastoralists in daily associations, they are not equipped to conduct substantial evangelism that will produce significant results.

${ }^{11}$ A number of lay-led mission agencies in Pokot are based in USA. According to the church leaders I interviewed, donations are given by friends and well-wishers. Some members of these groups travel once or twice a year to conduct evangelistic campaigns until another year when they travel back to continue from where they stopped. 
mission approaches, which may be effective in other contexts, is likely a significant cause for the plateaued state of mission among nomads.

\section{Importance of Specialization}

Even though specialization is blamed for fostering an attitude of expertise and professionalism that often creates dependency by "disabling everyone except the professional,"12 the approach is nonetheless useful when reaching cultural groups with unique beliefs and lifestyles. There are numerous advantages associated with specialization in ministry that could also benefit SDA mission efforts to nomads.

Recruiting, screening, cross-cultural training, equipping, and sending of workers who will become effective long-term missionaries is possible in a specialized ministry. ${ }^{13}$ This approach allows better planning and implementation of care for those working in the field as well as for the converts and new church members.

Through specialization, mission workers are enabled to be more focused, familiar with, and intentional with the target groups. Mission workers are able to spend adequate time learning the deeply held cultural beliefs and values of the targeted people. Sufficient time spent also enables missionaries to build stronger relationships, a strategy that leads to more fruitful witnessing.

\footnotetext{
${ }^{12}$ Vinay Samuel and Chris Sugden, eds., Mission as Transformation: A Theology of the Whole Gospel (Eugene, OR: Wipf, 2009), 303. Other perceived dangers of specialization include: (1) specialized thinkers often become closer to cultured despisers of the faith than to their fellow Christians; (2), expert knowledge is often pursued as an end in itself; (3), it is assumed that specialized knowledge can only be understood by the expert, creating a gap between experts and ordinary people; (4), development and originality are highly prized creating a misconception that the newer is truer and the latest is greatest; (5), it is often forgotten that ignorance is constant in human affairs and that the capacity to act is often greatest when the clarity of understanding is smallest; (6), members of the new knowledge class slowly adapt to the language and logic of the expanding world of seminars, forums, and congresses, moving further and further from Christianly discourses such as preaching and prayer.

${ }^{13}$ Olson, What in the World Is God Doing, 316.
} 
The specialization approach also enables the effective channeling of resources to high priority mission needs. Since those most directly involved are able to make quicker assessments and decisions when they are not required to maneuver through the bureaucracies of the higher levels of church organization, resources are likely to be more efficiently used.

Apart from the independent mission agencies and groups discussed in Chapter 3, a specialized denominational mission structure to guide ministry to nomads seems necessary for the SDA Church. Such an arrangement should be established at every level of the SDA Church structure, beginning with local fields and conferences with representation all the way to the General Conference level. Responsible leaders with indepth knowledge of nomads should be charged with organizing and facilitating mission activities that include research, as well as training and equipping workers to serve in nomadic contexts.

\section{Incarnational Ministry}

The invitation to share the gospel is multifaceted. Apart from proclaiming the claims of God as revealed in Scripture, the call for mission also challenges Christians to respond to human needs in the communities in which they minister. ${ }^{14}$ Incarnational ministry as founded and exemplified in the life and ministry of Christ and helps ensure

\footnotetext{
${ }^{14}$ For more information on the relationship between the proclamation of the gospel and the response to human needs, see Ronald J. Sider, Good News and Good Works: A Theology for the Whole Gospel (Grand Rapids, MI: Baker Books, 1999); Bryant L. Myers, Walking with the Poor: Principles and Practices of Transformational Development (Maryknoll, NY: Orbis Books, 1999).
} 
that the gospel is proclaimed through word as well as through deeds. ${ }^{15}$ Christ associated with people of all classes, teaching, healing the sick, feeding the hungry, raising the dead and comforting the bereaved. Through this approach, He was able to build relationships with people that enabled Him to share the gospel. Throughout subsequent generations, the Church has continued to emulate Christ's example of responding to human needs among its members and those in society as part of the greater call of announcing the good news of salvation, ${ }^{16}$ and also as a strategy of building bridges to witness.

\section{Foundations of the Incarnation Motif}

Christ's incarnated life and ministry demonstrate the scope and practicality of gospel proclamation. By embracing human nature and living among people Jesus indicated His physical presence among humanity (John 1:1-14). In order for Him to dwell among humanity, He became part of the human community although He was indeed God. He relinquished His divine power, keinosis, and became dependent upon God, just as any other human. Paul calls upon believers to have this same humble and self-sacrificing mind of Christ Jesus (Phil 2:5-8).

Christ's entering into the human sphere as a human and His life of humility and service provide the perfect model for ministry. The incarnation motif challenges those engaged in ministry to fully adopt the culture of their host people, just as Jesus identified

\footnotetext{
${ }^{15}$ Wagner Kuhn, Redemptions and Transformation through Relief and Development: Biblical, Historical and Contemporary Perspectives of God's Holistic Gospel (Benton Harbor, MI: Patterson, 2013), 212. Kuhn indicates that the gospel is multi-faceted, of which relief and development are an integral part. The integration of word and deed, being and doing, are characteristics of true holistic mission.

${ }^{16}$ Ibid., 79-107.
} 
with humanity (1 Cor 9:19-23; Phil 2:5). Jesus modeled holistic ministry, living out the gospel both in word and in action. While Christ focused on all humanity, He paid added attention to the underprivileged - the poor, oppressed, and marginalized of society. Incarnation proponents have argued that Jesus' example should be the basis for contextualizing the gospel and the Church. Missionaries are expected to mediate the life of Christ by becoming like Him to the people they serve (Gal 2:20; 1 Cor 11:1-2). ${ }^{17}$

As a model for Christian mission in the twenty-first century, incarnational ministry is thus an ideal and relevant approach to reaching marginalized groups like nomads. ${ }^{18}$ In contrast to other models, which fail to link the gospel with human social needs and fail to respond to cultural demands, an incarnational ministry requires that in addition to proclaiming the gospel, Christian witness effectively responds to human needs.

\section{Principles of Incarnation}

The incarnational approach generates four major principles that should guide witnessing activities among nomads. These principles that were exemplified in the life and ministry of Christ include presence, proximity, powerlessness, and proclamation. ${ }^{19}$

\footnotetext{
${ }^{17}$ John Cheong, "Reassessing John Stott's, David Hesselgrave's, and Andreas Köstenberger's Views of the Incarnational Model," in Missionary Methods: Research, Reflections, and Realities, eds. Craig Ott and J. D. Payne (Pasadena, CA: William Carey Library, 2013), 41.

${ }^{18}$ Hayward, "Ministry to Non-industrialized Peoples," 199.

${ }^{19}$ Allan Hirsh, The Forgotten Ways: Reactivating the Missional Church (Grand Rapids, MI: Baker Books, 2006), 133-140.
} 


\section{Presence}

By coming, assuming human nature, and dwelling among people, Christ not only defined God's view of culture but also demonstrated how God engages people at their cultural level. Christ's presence also points to His intentional purpose in mending broken relationships by living among people separated from Him by sin. In modern times when “in your face" approaches ${ }^{20}$ are prevalent and often the only known witnessing strategies, missionaries' physical presence in the community they minister to still form the backdrop of a successful Christian mission methodology. Allan Hirsh observes,

The presence of Christ in the Nazarene neighborhood for more than thirty years and no one noticed should be profoundly disturbing to our normal ways of engaging mission. .. . There is a time for "in your face" approaches to mission, but there is also a time to simply become part of the very fabric of a community and to engage in the humanity of it all. Furthermore, the idea of presence highlights the role of relationships in mission. It means we are going to have to be directly present to the people in our circle. ${ }^{21}$

The principle of presence challenges missionaries to be physically present among nomads, dwelling among them by traveling with them, sleeping in their huts, eating their food, and becoming aware of their interests, just as Jesus did with people in Israel. This practice will potentially build trust and positive relationships that prepare a conducive environment for witnessing. Strategies in which gospel workers mingle with nomads, leading them to greener pastures for their herds and more so to scriptural truths for their hearts are imperative. Provision of services for global mission pioneers who are likely to

\footnotetext{
${ }^{20}$ Ruth Tucker, Not Ashamed: The Story of Jews for Jesus (Colorado Springs, CO: Multnomah Books, 1999), 105.

${ }^{21}$ Allan Hirsh and Debra Hirsh, Untamed: Reactivating a Missional Form of Discipleship (Grand Rapids, MI: Baker Books, 2010), 134-135.
} 
spend considerable time with nomads and church structures that will account for the itinerate lifestyle should be considered. Presence also denotes the need for missionaries to lead an authentic Christian life of humility and genuine love, which presents a most compelling case for Christ. ${ }^{22}$

\section{Proximity}

Christ was not merely present in the streets, villages, or lakeside. He interacted with children, adults, men, women, lawyers, teachers, learners, mourners, revelers, and the hungry. His close association with people won Him favor, and many followed Him wherever he went. He ate and moved about with the outcasts and the marginalized, such as the Pharisees, prostitutes, and tax collectors. Ellen G. White writes, "Christ's method alone will give true success in reaching the people. The Savior mingled with men as one who desired their good. He showed His sympathy for them, ministered to their needs, and won their confidence, and then He bade them, follow me. ${ }^{23}$ Dean S. Gilliland also notes,

However theologically straight or doctrinally correct our teaching may be, the gospel is not good news if it does not provide answers to the felt needs of the people. This requires the messenger be in close and constant contact with people in order to know as deeply as possible their needs, their pain, their hopes and the injustices they feel. This kind of knowledge comes only by living in purposeful identity with them while studying their problems and searching for ways to meet problems once we know what they are. ${ }^{24}$

Missionaries in nomadic areas should not only to be present in a community but also available, consistent, and spontaneous in making friends and genuinely seeking their

\footnotetext{
${ }^{22}$ Paul G. Hiebert, Incarnational Ministry: Planting Churches in Band, Tribal, Peasant, and Urban Societies (Grand Rapids, MI: Baker Books, 1995), 146-147.

${ }^{23}$ White, Ministry of Healing, 143.

${ }^{24}$ Dean S. Gilliland, "The Incarnation as Matrix for Appropriate Theologies," in Appropriate Christianity, ed. Charles H. Kraft (Pasadena, CA: William Carey Library, 2005), 501.
} 
good. This readiness to meet human needs signifies decided efforts to address the social, economic, and spiritual needs of the community. Through the provision of basic needs like water, veterinary services for their animals, and health and education services, the love and closeness of the God who provides for human needs will be felt and is part of the missionary mandate. ${ }^{25}$

\section{Powerlessness}

Christ humbled Himself and took the form of a servant (Phil 2:5). He relinquished His power in order to give power and strength to the powerless. His Apostle echoed the same principle of powerlessness, particularly the apostle Paul, when he exclaimed, "I have become all things to all people so that by all possible means I might save some ... I do all this for the sake of the gospel that I may share in its blessings" (1 Cor 9:9-23). This servant-leadership modeled by Christ's incarnation and exemplified in His life should be emulated by church leaders and should define mission leadership in nomadic mission fields. The missionary should restrain from imposing an outsider's worldview upon the nomads and expecting and enforcing alien standards of behavior.

Powerlessness also means serving faithfully at the expense of personal rights and entitlements. Missionaries need to emulate Christ's powerless attitude in becoming all things to all so as to save some.

\footnotetext{
${ }^{25}$ Myers, Walking with the Poor; Sider, Good News.
} 


\section{Proclamation}

Proclamation encapsulates the whole essence of mission — sharing the gospel message. It is the enduring priority of Christian mission since human needs are fundamentally spiritual and eternal. ${ }^{26}$ In the context of nomadic regions where physical needs are widely spread and may divert attention from announcing forgiveness of sin and the love of God through Christ's sacrifice, it is advisable that the preaching of the gospel should remain the center of mission activities while addressing the needs of people.

Appropriate methods for sharing the gospel is fundamental in the proclamation principle. If Christ stepped down to speak to people in ways they could understand, missionaries should also be foremost in studying how nomads communicate and utilize those familiar means to speak the word of God. Incarnational communication should embrace the use of methods with which the respondents are acquainted. In place of foreign methods, which emphasize ideologies and abstract lessons, contextual methods ${ }^{27}$ should be applied.

Thus, by following Christ's example, missionaries will be faithful and true to the intents of the gospel through incarnational ministries to nomads. They should respond to human needs through ministries such as medical ministry, veterinary services, range and stock management, economic empowerment through alternative economic options, and training for appropriate trades such as bee keeping and carpentry.

${ }^{26}$ Dean Flemming, Recovering the Full Mission of God: A Biblical Perspective on Being, Doing, and Telling (Downers Grove, IL: Inter Varsity Press, 2013), 265.

${ }^{27}$ Jay W. Moon, "Discipling through the Eyes of Oral Learners," accessed February 15, 2015, http://mis.sagepub.com/content/38/2/127.full.pdf; Gideon Petersen, "God Speaks in the Heart Language," Journal of Adventist Mission Studies 5, no. 1 (Fall 2009): 98-109; Christine Dillon, Telling the Gospel through Story: Evangelism that Keeps Hearers Wanting More (Downers Grove, IL: InterVarsity, 2012), 98-109. 


\section{The Prayer Strategy}

In Christian witness, prayer is both a biblical imperative and a missional strategy. Several biblical texts call upon believers engaged in God's work to pray if success is to be realized. Missionary experiences throughout history also testify that prayer is an integral component for fruitful witnessing.

\section{Biblical and Historical Mandates for Prayer}

The imperative of prayer in mission work is rooted in God's admonition that people engaged in such work should pray. Both the Old and New Testaments provide examples of how prayers played a key role in God's work during challenging circumstances. In the journeys and advances of Israel for example, prayer enabled the people of God to defeat fierce nations, break down walls, and open closed territories. These include the fight against the Amalekites when Moses and Aaron employed the strategy of lifting Moses' hands up in prayer until the enemy was defeated (Exod 17:913) ${ }^{28}$ King Hezekiah's laying a letter in the temple while praying when Israel was facing the army of Assyria (2 Kgs 18; 19), and King Jehoshaphat's prayer and praise of Israel when confronted by the armies of the Moabites and Ammonites (2 Chr 20) among other prayers. God also urged Israel to seek Him in prayer: “Ask me, and I will make the nations your inheritance, the ends of the earth your possession" (Ps 2:8). Through the

\footnotetext{
${ }^{28}$ Bruce L. Bauer, "Intercessory Prayer and Mission,” Journal of Adventist Mission Studies 11, no. 1 (2015), 5. Bauer argues that Moses' intercessory prayer on behalf of Israel's army contains fundamental implications for the Church's mission and ministry to unreached or unchurched peoples. He states that since mission and ministry is a spiritual endeavor - a spiritual battle against the strongholds of evil, Church institutions such as schools, clubs, Bible classes, hospitals and clinics to unreached peoples can be much more effective in a teamwork environment. Intersessions from committed believers for those doing the actual ministry is indispensable.
} 
prophet Jeremiah, God pleaded with Israel to, "Call to me and I will answer you and tell you great and unsearchable things you do not know" (Jer 33:3).

The New Testament also indicates that prayer was key in the life and ministry of Jesus. He prayed and urged His followers to pray. When sending out the seventy-two disciples, Christ asked the disciples to pray so that the Lord of the harvest would send out laborers because the fruits were plentiful, yet the laborers were few (Matt 9: 37-38). He prayed for His Father to bring workers to the field, and for believers to be one with God and with one another (John 17:20-23). After Christ's ascension, fervent prayer and fasting marked the life and ministry of the early Church as believers advanced their witness throughout the world (Acts 1:4, 24-25; 4:31).

The biblical record also indicates the Apostle Paul constantly interceded for the churches he established during his missionary journeys. He appealed to the early Church to pray "that God may open a door for our message, so that we may proclaim the mystery of Christ" (Col 4:2-3). Paul reminded the Church that Christian warfare is "not against flesh and blood, but against the rulers, against the authorities, against the powers of this dark world and against the spiritual forces of evil in the heavenly realms" (Eph 6:12). These incidences show that there is a direct connection between the prayers of God's people and breakthroughs in the accomplishment of God's purpose in the world.

Apart from biblical evidence, the history of Christian mission is also marked by intentional prayers of those who had a vision and desire to witness for God. Mission history indicate that most modern mission movements were birthed through the prayers of committed and passionate people who desired to share the gospel in foreign regions. These include the Moravian Christians, who are remembered for their famous prayers for 
the evangelization of unreached souls, involving twenty-four hour a day prayers for one hundred years. ${ }^{29}$ The Nottingham Baptist Association of England also participated in months of prayer sessions for evangelism, which resulted in the birth of a mission movement by William Carey and his supporters in 1782.

Other examples of prayers for mission-work include the Pee Dee Baptist Association of South Carolina. As a result of their intense prayer sessions and concerts in $1802,{ }^{30}$ Adoniram Judson and others were sent to Asia as missionaries. Strategic prayer also led to the formation of the Student Volunteer Movement in Massachusetts' Williams College in $1806 .^{31}$

\section{Challenges Necessitating Prayer}

The challenges associated with cross-cultural mission are immense. Apart from the difficulties and obstacles missionaries experience when leaving their familiar surroundings, there are also economic and social obstacles their people often face that hinder them from hearing the gospel. In addition to those discussed previously, these challenges include injustices, suffering, alienation, and marginalization from those in authority. ${ }^{32}$ Antagonistic spiritual forces are also in constant battle for territorial control and supremacy, seeking to keep people under their dominion by preventing the light of

\footnotetext{
${ }^{29}$ R. Alton James, "Post Reformation Missions Pioneers," in Discovering the Mission of God: Best Missional Practices for the 21st Century, ed. Mike Barnett (Downers Grove, IL: InterVarsity, 2012), 263.

${ }^{30}$ David Claydon, A New Vision, a New Heart, a Renewed Call (Pasadena, CA: William Carey, 2005), 377.

${ }^{31}$ Ibid.

${ }^{32}$ John D. Robb, "Strategic Prayer," in Perspectives on the World Christian Movement: A Reader, eds. Ralph D. Winter and Steven C. Hawthorne (Pasadena, CA: William Carey Library, 2009), 164.
} 
the gospel from reaching them. These situations necessitate intersession for divine intervention to allow openness and receptivity to the gospel, to ensure missionaries' welfare and comfort, and to gain power over aggressive and hostile spiritual forces.

\section{Praying as Spiritual Warfare}

Obstacles must be removed to allow God's Word to spread rapidly and freely. Among the pastoralists are people from animistic backgrounds, or those with traditional religious beliefs such as ancestral worship, belief in mystical powers, and fear of spirits. By trapping individuals as well as whole communities in false worldview assumptions concerning reality, Satan and his hosts obstructs allegiance to God by holding people in strongholds of self-sufficiency. ${ }^{33}$ For missionaries to penetrate such deeply in-grained worldviews and spiritual strongholds with the gospel, a powerful encounter with the Holy Spirit is required, ${ }^{34}$ something that is often made available through prayer (Luke 11:13).

\section{Praying for Openness and Receptivity}

Although groups such as pastoralists have been resistant to Christian influences due to errors on the parts of previous missionaries, ${ }^{35}$ it is also true that Satan has constantly sought to blind people concerning their spiritual reality by forging false security through cultural traditions. A direct attack on Satan's evil kingdom through prayer and gospel proclamation should also be a model for mission to nomadic people.

${ }^{33}$ Robb, "Strategic Prayer," 164.

${ }^{34}$ For a biblical exposition of how Christ and the early Church confronted spiritual powers, see Peter C. Wagner, Confronting the Powers: How the New Testament Church Experienced the Power of Strategic-level Spiritual Warfare (Ventura, CA: Regal, 1996).

${ }^{35}$ Hunter, "Think Nomadic," 9-13. 
This approach was best manifested in Christ's life and ministry and has also been a characteristic of mission history. ${ }^{36}$

Praying for openness and receptivity of to the gospel is also a decisive weapon against the powers of injustice, oppression, war, suffering, disease, and other evils caused by cooperation with Satan. ${ }^{37}$ Paul's appeal to the early Church to pray so that God may open a door for the gospel ( $\mathrm{Col} 4: 2-3)$ should be an example for those working among nomads as well. The need to have access to regions where Satan is actively engaged in territorial demonic presence and warfare, ${ }^{38}$ for recognition of open doors, for removal of all barriers so that people can be receptive, and for willing partners, sponsors, and mission friendships are pertinent reasons necessitating prayer. ${ }^{39}$

\section{Praying for Missionaries}

Praying strategically for missionaries is equally important. Even with thorough preparations regarding cultural differences, world religions, diverse worldviews, and how

\footnotetext{
${ }^{36}$ Arthur F. Glasser et al., Announcing the Kingdom: The Story of God's Mission in the Bible (Grand Rapids, MI: Baker Books, 2003), 329.

${ }^{37}$ Robb, "Strategic Prayer," 164-165.

${ }^{38}$ A discussion on spiritual warfare and territorial spirits is now emerging in evangelical circles from Pentecostal backgrounds. See Phillip Botha, Demonology: Demons and Devils /Spiritual Warfare (Raleigh, NC: Lulu, 2012); Ott, Strauss, and Tennent, Encountering Theology, 257-259; C. Peter Wagner, Territorial Spirits: Practical Strategies for How to Crush the Enemy through Spiritual Warfare (Shippensburg, PA: Destiny, 2012).

${ }^{39}$ Susan Payne, "The Role of Prayer in Ministries Dependent upon Donations," Journal of Adventist Mission Studies 11, no.1 (2015), 1. According to Susan Payne, the experience of Nehemiah in seeking aid from the King (Neh 1) for the rebuilding of the Jerusalem temple, teaches that God is the source of everything and that aligning a ministry with God's goals is of utmost importance and is achievable through prayer.
} 
to face hostility from host governments, ${ }^{40}$ missionaries often contend with spiritual obstructions, cultural dilemmas, and resistant attitudes. There are also social, psychological, and economic uncertainties that confront those working outside of familiar contexts. ${ }^{41}$ Some abandon their work or are unwilling to be engaged in ministry within difficult contexts.

Like regular people, the fear of pain, rejection, failure, economic uncertainties, embarrassment, and evil forces are real for missionaries. They are often separated from their families, spend prolonged periods of time in solitary places, particularly those serving in nomadic contexts. ${ }^{42}$ They need God's strength to stand firm in the midst of these challenges.

Christ's prayer that God would send missionaries affirms that God directs missions and that it is God's responsibility to provide and prepare willing and suited workers for the mission field. ${ }^{43}$ Because of its uniqueness, the pastoralists' mission field requires God-appointed, love-driven, self-sacrificing, and willing missionaries who can

${ }^{40}$ Bruce Ashford, Theology and Practice of Mission: God, the Church, and the Nations (Nashville, TN: B and H, 2011), 188-195.

${ }^{41}$ For a comprehensive examination of challenges missionaries face, see Tom Steffen and Lois McKinney Douglas, Encountering Missionary Life and Work: Preparing for Intercultural Ministry (Grand Rapids, MI: Baker Academic, 2008); Lyman E. Reed, Preparing Missionaries for Intercultural Communication: A Bi-cultural Approach (Pasadena, CA: William Carey Library, 1995).

${ }^{42}$ Cheryl Savageau and Diane Stortz, Parents of Missionaries: How to Thrive and Stay Connected When your Children and Grand Children Serve Cross-culturally (Colorado Springs, CO: Authentic, 2008). Savageau and Stortz offer grandparents steps for dealing with loneliness when children and grandchildren leave for the mission field.

43 "Matthew 9: 37-38," John Gill's Exposition of the Bible, accessed September 10, 2016, http://www.biblestudytools.com/commentaries/gills-exposition-of-the-bible/matthew-9-38.html. The disciples could not make, qualify, and send out laborers themselves. Only God could fulfill the petition to send because the work is God's. It is God who furnishes one with ministerial gifts for work and engages people in service. The laborers to be sent are to be faithful, diligent, and industrious witnesses of the gospel in whatever context they are placed. 
serve in challenging conditions. Paul requested prayers for boldness that he might "fearlessly make known the mystery of the gospel" (Eph 6:19). Prayers for missionaries should focus on their welfare and their success in ministry, that they may appropriately communicate the gospel.

Interceding for nomads is equally important. As discussed in previous chapters, nomadic people are challenged economically, socially, and are generally alienated and marginalized. Their survival is generally dependent on divine intervention through natural resources, such as sufficient rain, or charity and relief from well-wishers. Prayers for the health of the people and their livestock, reliable rain, sufficient food, and a peaceful daily life are important. ${ }^{44}$ Concern for their welfare and sympathy for their plight will involve praying for, and with nomads, as indicative of being in solidarity with their struggles.

\section{Group Focused Evangelism}

Like most African tribal groups, the nomadic societies of Kenya are culturally knit together with a strong social fabric. Members of the groups are obliged to adhere to the social order requiring obedience to societal regulations and laws that govern daily life, particularly respect for the elders' authority. ${ }^{45}$ Defiance of this order, for internal or

\footnotetext{
44 Throughout the day, the Pokot offer prayer. Their songs are prayers for blessings of rain, peace, health, and protection.

${ }^{45}$ For information on the elders' position in tribal and African societies, see Levinson, Encyclopedia of World Cultures, 157; B. A. Rwezaura, "Changing Community Obligations to the Elderly in Contemporary Africa," Journal of Social Development in Africa, 4, no. 1 (1989), 5-24; Gunnar Landtman, The Origin of the Inequality of the Social Classes (New York, Routledge, 2016), 313.
} 
external reasons, ${ }^{46}$ is believed to cause turmoil, misfortunes, and disharmony, as a punishment from divine beings. ${ }^{47}$ Unlike the West where individuals can make personal decisions, such as a commitment to follow Christ, important decisions among nomads are collectively made by families, clans, or by the elders. ${ }^{48}$

For the Pokot, cultural traditions prescribed by past generations are highly valued and adherence to the social order is a fundamental requirement for maintaining poghishyo (peace). The unquestionable respect and authority of the elders and the required obedience to societal regulations is presumed to be the will of tororot (god). This communal lifestyle involving group decisions, obedience to social edicts, and the high regard for authority impacts any approach used to witness to nomads. ${ }^{49}$ While the gospel at its core emphasizes the individual decision of renouncing sin and following Christ as Lord and personal savior, communally-oriented nomads must be reached nevertheless. How will this personal dimension of the gospel be applied among nomads?

The International Mission Board describes a people group as "an ethno linguistic group with common self-identity that is shared by various members. ${ }^{, 50}$ Shared cultural traditions, including language, play a key role in uniting people. Although other aspects

\footnotetext{
${ }^{46}$ Colonialism and Western influences are generally viewed as causes for disregard of the social order in African tribal life. See Olúfémi Táíwò, How Colonialism Preempted Modernity in Africa (Bloomington, IN: Indiana University, 2010), 94.

${ }^{47}$ See an example among the Pokot in Jónsson, "Pokot Masculinity," 17.

${ }^{48}$ Hiebert, Gospel in Human Contexts, 91.

${ }^{49}$ Ibid.

${ }^{50}$ Orville Boyd Jenkins, "What is a People Group?” accessed December 22, 2016, http:// public.imb.org/globalresearch/Pages/PeopleGroup.aspx.
} 
of culture may become barriers for the gospel, when not addressed, language is the greatest obstruction to witness within a people group. ${ }^{51}$

Effective evangelism to nomads will require witnessing to them within their social groupings, such as families, villages, or clans, rather than as individuals. Accepting the gospel message individually through a public evangelistic campaign may be viewed as an abandonment of community values, which often results in the rejection or expulsion of converts from their families or community. ${ }^{52}$

The people-group approach is effective in communicating the gospel to homogenous societies. Through the Homogeneous Unit Principle advocated by church growth developers, it is observed that people "like to become Christians without crossing racial, linguistic, or class barriers." ${ }^{53}$ Being the largest group through which the gospel can flow without encountering significant cultural or linguistic barriers, ${ }^{54}$ the people group approach remains an effective strategy for witnessing to communities such as the Pokot because of their shared language and cultural tenets. This approach ensures that the gospel will spread through "natural" social networks. Rondal Smith has written,

People groups are the natural and logical choices for communicating with the individuals within them. Even though these individuals differ from each other in unique ways, they nevertheless have much in common attitudinally, behaviorally, and linguistically. By definition, communication flows in regular structured ways among those within the group. Our task as agents bringing a new message is to work with

51 Lewis, World Mission, 7-8.

52 Paul Keidel, Career-defining Crises in Mission: Navigating the Major Decisions of Crosscultural Service (Pasadena, CA: William Carey Library, 2013), 72.

${ }^{53}$ McGavran, Understanding Church Growth, 223.

${ }^{54}$ J. Scott Holste, "Finishing the Task," in Best Missional Practices for the 21 st Century: Discovering the Mission of God (Downers Grove, IL: InterVarsity, 2012), 326. 
those who desire in order to discover how to communicate the message of Christ in their codes, categories and channels of communication. ${ }^{55}$

People-group-focused evangelism is also appropriate for the Pokot people because community-oriented societies are likely to convert in groups. ${ }^{56}$ Individual allegiance to family or clan is higher than individual decisions and pursuits. Communal decision-making ensures respect, identity, traditions, and social order. The Pokot whose culture requires obedience to elders' authority will require missionaries to recognize such cultural arrangements. The targeting of people as a group — in clans or villages — rather than individually will ensure that Christian witnesses are viewed as respectful of Pokot culture and not its destroyers.

The people-group strategy is also biblical. During the early Church experience, people came to Christ in groups. After the healing of Aeneas, "all those who lived in Lydda and Sharon saw him and turned to the Lord" (Acts 9:35). Paul and Silas also urged the jailer to believe in Jesus as a prerequisite of salvation for himself and his household (Acts 16: 29-31).

Adequate post-conversion care is crucial in the people-group strategy. Effective Bible studies and discipleship of converts in order to engage them in ministry are some of the ways of nurturing converts from group conscious backgrounds, enabling them to mature in faith. ${ }^{57}$

\footnotetext{
55 Rondal Smith, "Strategy for World Evangelization," in Completing the Task: Reaching the World for Christ, ed. Edgar J. Elliston and Stephen E. Burris (Joplin, MO: College Press, 1999), 137-138.

${ }^{56}$ Charles Van Engen, Nancy Thomas, and Robert Gallagher, eds., Footprints of God: A Narrative Theology of Mission (Eugene, OR: Wipf and Stock, 1999), 69.

${ }^{57}$ C. Peter Wagner, Strategies for Church Growth: Tools for Effective Mission and Evangelism (Eugene, OR: Wipf and Stock, 2010), 187.
} 


\section{Summary}

Four missional strategies to assist in creating contacts with the pastoralists have been presented in Chapter 6. The incarnational ministries strategy challenges mission workers to proclaim the gospel by word and deed. The nomads' socio-economic needs must be addresses as way of creating a more suitable environment for sharing the gospel.

The nature of the specialization strategy is mostly administrative. Since nomads present a unique mission context, a specialized ministry ensures that individuals with a deeper understanding of the pastoralists' lifestyle and values are mobilized, trained, and equipped to carry on mission work among nomads.

Strategic prayer is a foundational principle for any witnessing activity. The powers of darkness can only be confronted by the authority of God, which is accessible through prayer. Strategic prayer opens closed doors for witnessing and provides the witness with wisdom and God's leadership.

Finally, witnessing to pastoralists requires a people group approach. The strong relationships and communal mindset that characterize pastoralists are in contrast to the individualistic emphasis that Western missionaries usually adhere to. Instead of targeting individuals who are largely limited in their ability to make personal decisions, nomads should be witnessed to as families or clans.

The next and final chapter will present a summary of the findings of this research, recommendations, and the conclusions of this study. 


\section{Chapter 7}

\section{SUMMARY, RECOMMENDATIONS, AND CONCLUSIONS}

\section{Introduction}

Seventh-day Adventist growth in Kenya is more developed and established among settled communities than among nomadic peoples. An absence of churches or low membership in pastoral nomadic territories is evident and indicative of the lack of SDA mission dynamism in the region. This state of witness, which is also true among other Christian groups, suggests that witnessing to pastoralists is a persistent challenge. A limited understanding of the cultural worldviews of pastoralists, a unique life of constant movement without a permanent abode, and ineffective mission methods are among the reasons attributed to nomads' poor responses to and alienation from the gospel message.

The study of the Pokot cultural worldview sought to accomplish three purposes: (1) describe the underlying features of the community's culture by examining the reasons for what they do, (2) analyze witnessing challenges arising from the Pokot culture and physical contexts and (3) propose appropriate and effective approaches that would potentially expedite a more dynamic and relevant witness among the Pokot and other nomads in the East Africa region. By tapping into their cultural value systems, knowing their socio-cultural needs, and evaluating current witnessing strategies, it is hoped that the proposed model of mission will allow the development of appropriate mission bridges that will ensure the Pokot and other pastoralists hear and respond to the gospel in their 
cultural context. This is a necessary step toward realizing the purpose and goal of SDA mission among nomads.

\section{Summary}

Worldview is the bedrock of a people's understanding of life and the driving force behind cultural practices and customs. Beneath the visible aspects of culture are worldview assumptions that guide people to choose or act in certain ways. Among other functions, worldview provides answers to humanity’s fundamental questions, offers emotional stability during a crisis, monitors cultural change from outside influences, authenticates people's values, integrates ideas into a greater whole, and assures people that the world is, and should be, what it appears to be. Although debate over the validity of this concept exists among modern anthropologists, the theory is nonetheless a useful tool in Christian mission.

Sharing the gospel cross-culturally demands an understanding of people's deep cultural assumptions apart from the visible structures that are openly manifested. These assumptions describe the thought processes of individuals, processes which allow them to make decisions, pledge their allegiance, and commit their lives to a cause.

One of the values of understanding worldview in mission is that it allows one to address people's deep fears, desires, and knowledge. Apart from the visible modifications of a Christian life, genuine transformation occurs deep in the heart and this is only possible when worldview assumptions are addressed. As this study demonstrated, focusing on worldview is a necessary and crucial step toward holistic transformation and the development of a Christian worldview. People must be guided into finding answers in 
Scripture, their worldview changed through the process of conversion, and their lifestyle based on biblical teachings.

Second, understanding worldview ensures that cultural values are respected. Values such as respect, generosity, kindness, humility, and helpfulness are not only promoted in most cultures, but are also biblical admonitions for God's people. Contrary to early Christian missions in foreign lands, when the respondent's culture was neglected or presumed heathen, effective witness should emphasize the desire to understand the people's cultural values through which God may communicate His ideal way of life. This approach allows for the building of missional bridges and ensures that God's Word is presented and practiced in the culture of the respondents, and is not just a reproduction of the missionary's way of life.

\section{Nomadic Cultures}

Nomads have been in existence since Old Testament times. Biblical figures such as Abraham, Isaac, Jacob, and their descendants led a nomadic lifestyle, accepted God's call, and were used by Yahweh to reach others. Since then, nomadic people have spread to all the continents of the world. In spite of the biblical evidence of their humble life and obedience to God's call and mission, modern-day nomadic people groups are the least reached with the gospel. Groups such as the Pokot are still without any significant Christian presence, even though Christian influences are within their reach. This study showed that unfamiliarity with the nomad's cultural values and lifestyle leads to unproductive witness. Lack of understanding also leads causes marginalization and results in insensitivity to felt needs, which again impedes the process of witnessing. 
God's mission demands that the gospel be proclaimed among the Pokot and other pastoralists just as it is among settled groups. In spite of their cultural uniqueness, nomads are to be presented with the Good News in ways that are relevant, contextual, and appropriate to their lifestyle. Mission agents such as the Church, individuals, and agents are invited to be part of the call to proclaim the gospel, guided by the Holy Spirit, while grounding their work in the Bible.

The Pokot Worldview

The Pokot of Western Kenya and Eastern Uganda are one of many pastoral groups in the region. In spite of being challenged socially and economically, the Pokot are resilient hard-working people with survival tactics suited to meeting their specific challenges. Their itinerant lifestyle in search of water and pastures is one of the many adaptive dynamics that define them. Tribal clashes between the Pokot and their neighbors are common and are necessitated by conflicts over grazing land.

The Pokot cultural political structure is still recognized and operates side by side with the modern government structure. Egalitarianism defines authority within the community, which is fundamentally a decentralized power system. A council of experienced elders, kokwo, oversees the affairs of the people by presiding over disputes, deciding cases, and maintaining peace and morality among the Pokot.

Religion plays a significant role in every aspect of Pokot life. Sacrifices, rituals, prayers, songs, and chanting are offered on a regular basis to appease Tororot (god) and seek guidance, blessings, and protection. The Pokot god is believed to communicate through ilat (rain) and asis (sun). Angering these divine beings may result in calamities such as disease, hunger, or death. 


\section{A Comprehensive Approach}

A comprehensive model for mission is proposed to guide Christian mission among the Pokot and other pastoralists. Seven strategies for cross-cultural mission were examined. Transformation of worldviews tops the list of steps toward forming mature Christians whose faith and practice is biblically based and spiritually guided. Second, for the nomads to hear and respond to the Word of God in their cultural setting, a contextualized mission and ministry is necessary. The use of oral methods such as stories, songs, proverbs, sayings, and riddles guarantees that the gospel will be communicated in ways that nomads can appreciate.

A contextualized ministry should also involve establishing church structures that are compatible with a nomadic life and the training of missionaries should emphasize methods that can provide ministry in nomadic contexts. Additionally, incarnational ministries to respond to felt needs among pastoralists are required. Poverty, disease, and limited sources of water are among the many challenges nomads face. Christians can address these pressing needs through specific ministries, which provide solutions or empower the nomads in their daily lives.

In addition, specialization focused ministry to nomads is essential. Nomadic contexts are unique in comparison to settled environments where Christianity is better established and from which most missionaries originate. Among the benefits of specialization are the mobilization of a skilled workforce and better management and channeling of resources. A prayer strategy is also of utmost importance because human activities are insufficient unless they are guided and energized by divine power. 
Interceding for divine intervention on behalf of missionaries and nomads is a necessary strategy toward realizing success.

Finally, there is need for a group-oriented approach to evangelism among nomads. Groups such as the Pokot are communal by nature, and Christian mission must be sympathetic to their social structures. Community elders should be engaged by seeking their permission when working among their people.

\section{Recommendations}

In response to these cultural challenges I offer the following recommendations:

1. Investigation into nomads' cultural values should continue to develop as a part of the goal of SDA mission. Because of the complexity and depth of people's cultures, one study is not sufficient to provide a complete understanding of any nomadic group. Although various studies have been conducted in the past, developing mission models for the nomads requires further studies and should be a continuing task by those involved with gospel proclamation. Research and compilation of stories, proverbs, sayings, songs, and myths should be encouraged, as these will assist in developing mission bridges and discovering redemptive analogies for sharing the gospel.

2. Formal and informal education to train and equip missionaries and ministers with skills necessary for serving in nomadic contexts should be developed and maintained. Educational programs such as the one offered at the University of Eastern Africa-Baraton should be expanded to include periodic seminars, refresher courses, and mission symposiums to better equip and enable mission personnel to serve skillfully and appropriately. The curriculum should include training preachers in story-telling skills and insights on the formation of social groups. 
3. Specialization for ministry to nomads is required. This calls for the involvement of lay workers, ministers, administrators, academics, researchers, and others in formulating policies and models that will guide ministry for nomads. Church administrators in particular should spearhead ministry to nomads through moral and material support, ensuring allocation of funds for specialized approaches.

4. Developing centers of interest where nomads can rejuvenate spiritually, socially, and physically should be considered. These centers can be supply points for relief food, such as water, clothing, and shelter from extreme weather. Worship, Bible studies, and nurture of converts can also be conducted in these centers.

5. Periodic mission progress reports from the nomadic world should be encouraged. These reports should highlight challenges encountered, witnessing opportunities, successes achieved, and proposals for a way forward. Such reports are likely to inspire and rally others for mission as well as guide informed policymaking.

6. Established churches and agencies, particularly from agriculturally rich areas, should be mobilized to participate and be stakeholders in mission to nomads. These groups can be influential in the distribution of food resources to relieve hunger among the nomads during dry seasons.

7. Local funding and ownership of mission to the nomads is vital. In place of the continual attitude of dependency on foreign funds and personnel, the SDA Church in Kenya should tap into the local community for funding and equipping resident missionaries to work among the nomads.

8. The Church must work to create an awareness of the mission field and needs of the Pokot and other nomadic groups. Through various forums such as workers' meetings 
and camp-meetings, efforts should be made to inform church members, individuals, and agencies about the state and needs of mission work in nomadic regions.

9. The creation of a department that oversees, directs, and monitors evangelism to Kenya's nomads is highly recommended. This can begin in local fields and conferences and expand to unions and divisions as needed.

10. Creation of special transitory congregations that will accommodate periodic movement be established in nomadic regions. These nomadic churches patterned after the Old Testament religious model can benefit present-day nomads who are bent on moving when need arises.

\section{Conclusion}

From biblical times, God has called people from different cultural backgrounds into a saving relationship. Nomadic patriarchs such as Abraham, Isaac, Jacob, Moses, and the prophets entered into a saving covenant with God, after which, God sent them to reveal and proclaim the gospel message, not only to their immediate families but also to their neighbors and others in foreign lands. Most nomads grew in their faith and love for God, some choosing to remain and die for their faith without receiving or seeing the promises they passionately championed. Scripture clearly indicates that most of the faithful nomads considered themselves sojourners on earth, seeking for a better heavenly country.

With the passing of time, the lifestyle of the biblical nomads was transformed and became synonymous with a settled lifestyle. Developments such as the Renaissance and the printing press aided in transforming Christianity into a religion of the book, of the settled, and of the literate. Historical methods of instruction and learning Scripture 
through storying stopped from mission practice and evangelism through formation of relationships, disappeared. These methods were replaced by systems such as mission stations and public evangelism. These approaches have continued into the present time, in spite of continued cultural diversity in the human experience.

Consequently, nomads who are essentially oral communicators and communityoriented have been gradually alienated from hearing the gospel claims in a manner they can understand. Missionaries who mostly hail from settled areas and who understand the gospel from their familiar established perspectives often show minimal consideration to the nomad's cultural communication methods.

This missional challenge necessitates developing models for mission among nomadic peoples. In order to allow for a smoother transmission of the gospel, such models should comprehensively address the cultural distance, which often exists between missionaries and the targeted communities. The comprehensive model discussed in this research seeks to guide SDA mission activities among the nomads of Kenya in a more holistic manner by: (1) addressing their deeply held cultural worldview values regarding origins, God, sin, forgiveness, tragedy, and destiny, and (2) appropriately responding to their spiritual, physical, and social needs.

Through the seven fundamentals for cross-cultural witnessing, the comprehensive suggested model effectively addresses the culture factor. This model requires missionaries to be purposeful in familiarizing themselves with the nomads' world, experiencing the life of nomads through mingling with them and seeking their good. This approach should enable missionaries to build mission bridges for sharing and communicating the gospel more appropriately. 


\section{APPENDIX A}

\section{MAP OF KENYA}

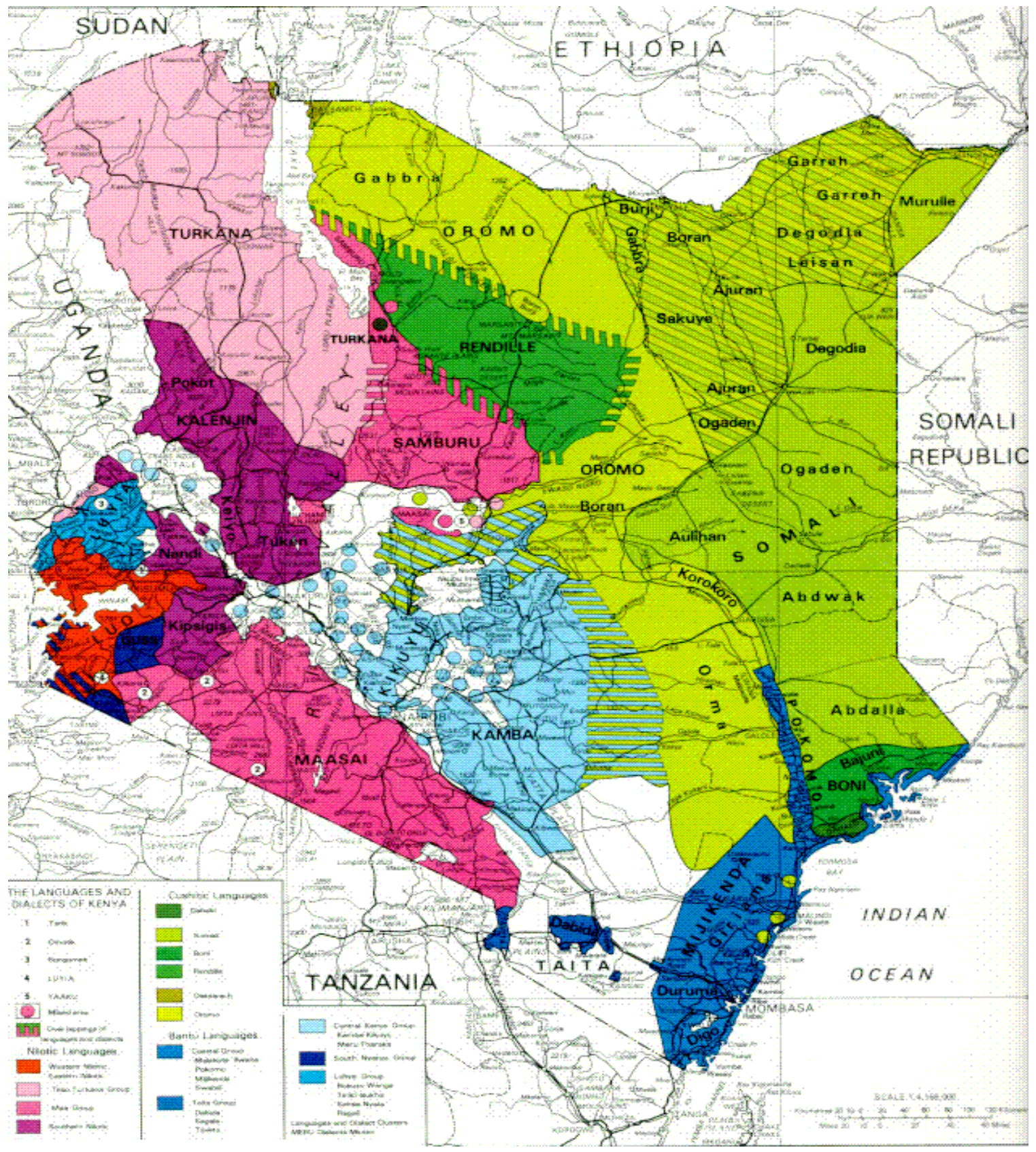

Map showing tribes of Kenya. From the Wildgens,

http://www.thewildgens.com/ministry/maps.html (accessed July 1, 2016). 


\section{APPENDIX B}

\section{POPULATION DISTRIBUTION OF KENYA'S NOMADS}

\begin{tabular}{|c|c|c|}
\hline Pastoral Group & Distribution Areas & $\begin{array}{l}\text { Estimated } \\
\text { Population }\end{array}$ \\
\hline $\begin{array}{l}\text { Boran, Gabbra, } \\
\text { Orma }\end{array}$ & $\begin{array}{l}\text { Eastern Province, Moyale, Isiolo, and Marsabit } \\
\text { districts }\end{array}$ & 176,000 \\
\hline $\begin{array}{l}\text { Daasanach } \\
\text { (Merille) }\end{array}$ & $\begin{array}{l}\text { Eastern Province, Marsabit District, Lake } \\
\text { Turkana northeast shore, Illeret area }\end{array}$ & 9,000 \\
\hline Maasai & Rift Valley Province, Kajiado and Narok districts & 750,000 \\
\hline Pokot & $\begin{array}{l}\text { Rift Valley Province, Baringo and West Pokot } \\
\text { districts }\end{array}$ & 335,000 \\
\hline Rendile & $\begin{array}{l}\text { Eastern Province, Marsabit District, } \\
\text { between Lake Turkana and Marsabit Mountain }\end{array}$ & 44,000 \\
\hline Samburu & $\begin{array}{l}\text { Samburu District, Lake Baringo south and east } \\
\text { shores; Rift Valley Province (Chamus), Baringo } \\
\text { District. }\end{array}$ & 185,000 \\
\hline Somali & Northeastern Province, Wajir area & 487,000 \\
\hline Turkana & $\begin{array}{l}\text { Rift Valley Province, Turkana, Samburu, Trans- } \\
\text { Nzoia, Laikipia, Isiolo districts, west and south } \\
\text { of Lake Turkana; Turkwel and Kerio rivers. }\end{array}$ & 479,000 \\
\hline Total & & $2,500,000$ \\
\hline
\end{tabular}

Source: Data from Lewis M. Paul ed., Ethnologue: Languages of the World, 16th ed., Dallas, TX: SIL International, 2009.

SDA Membership among the Nomads

\begin{tabular}{|l|c|c|l|}
\hline Language Group & Population & SDA Membership & Percentage \\
\hline Boran, Gabbra, Orma & 495,000 & 0 & 0.0000 \\
\hline Daasanach & 48,000 & 0 & 0.0000 \\
\hline Maasai & 590,000 & 200 & 0.0333 \\
\hline Turkana & 451,000 & 243 & 0.0359 \\
\hline Rendile & 34,700 & 0 & 0.0000 \\
\hline Somali & 420,500 & 0 & 0.0000 \\
\hline Samburu & 173,500 & 15 & 0.0083 \\
\hline Pokot & 384,000 & 1287 & 0.3299 \\
\hline
\end{tabular}

Source: Data from, East-Central Africa Division Unreached Assessment Report, April 22, 2010. 


\section{APPENDIX C}

\section{SAMPLE INTERVIEW PROTOCOLS}

Category 1: Interview of Pokot elders.

1. Where do your people say/believe they were to have come from and what made them move to this place?

2. Who are the most important/known historical figures among your people?

3. Which are some of the most significant historical events in Pokot history?

4. According to your people's beliefs, where do people go after death?

5. In Pokot customs, who makes decisions for the family, village, or community?

6. What do parents expect of/wish for their children?

7. Are there times when misunderstandings arise in the family, village, or community? If yes, what are some of them?

8. How do your people resolve misunderstandings?

9. Can you describe for me what makes a person successful? What makes a person a failure?

10. What does the death of cows or other animals mean to your people?

Category 2: Interview of Joseph Parklea, who is ministering among the pastoralists

1. How long have you served in this ministry?

2. Apart from the Pokot, have you ministered among other nomads elsewhere?

3. What do you enjoy/like about the ministry among the nomads?

4. What are some of the challenges/obstacles you are facing in your ministry?

5. What beliefs and cultural practices of the Pokot people are you aware of?

6. Among these practices, which ones do they value most? 
7. How would you describe the Pokot people's attitude toward Christianity or Adventism?

8. What methods do you employ in communicating the gospel among the Pokot people?

9. Among these methods, which ones are more appealing and attract their attention?

10. In your assessment, what are the main reasons for the low membership among the Pokot people?

11. What would you suggest as a solution to improve ministry among the Pokot and other nomadic communities in Kenya?

12. Is there any support you would like to have in your ministry to the Pokot?

13. From whom do you expect it?

\section{Category 3: Interview of Paul Girimbe and Rafael Wanyonyi}

1. How long have you served in this position?

2. Which regions of the Conference/Union are the main focuses of evangelism this year?

3. Which areas of the Conference/Union do you consider unreached or least reached?

4. What do you consider the main reason these areas are still unreached?

5. What are some of the nomadic groups within the Conference/Union?

6. Specifically regarding the Pokot, what are some of their cultural beliefs and practices that you are aware of and how strong are they attached to these beliefs and practices?

7. Are there any documented reports on the progress of work among the Pokot and other nomadic groups?

8. How has affinity to culture impacted mission among the nomads?

9. How would you describe ministry among the Pokot and other nomadic groups (i.e. successful, failing, unfruitful)?

10. Which individuals or groups have worked among the Pokot in the past or currently working? 
11. How familiar are these workers with nomadic culture?

12. How often are these workers in-serviced or trained to minister to the nomads?

13. What methods of evangelism are being recommended/employed for use among the Pokot?

14. What are some of the challenges reported while ministering the nomads?

15. What is the general response to the gospel that is being reported from nomadic regions?

16. Have you considered new approaches for ministry among the nomads?

17. Is there any support you would like to have in your ministry to pastoral communities?

18. From whom would you like such support to come from? 


\section{BIBLIOGRAPHY}

Adeney, Miriam. "Feeding Giraffes, Counting Cows, and Missing True Learners: The Challenge of Buddhist Oral Communicators." In Communicating Christ Through Story and Song: Orality in Buddhist Contexts, edited by Paul H. De Neui, 77-107. Pasadena, CA: William Carey Library 2008.

Adler, Emily, and Roger Clark. How It Is Done: An Invitation to Social Research. Belmont, CA: Thompson Learning, 2008.

Adogame, Afe, Janice McLean, and Anderson Jeremiah, eds. Engaging the World: Christian Communities in Contemporary Global Societies. Eugene, OR: Wipf and Stock, 2014.

Advameg. "Pokot Religion and Expressive Culture." Countries and Their Culture. Accessed July 8, 2016. http://www.everyculture.com/Africa-Middle-East/PokotReligion-and-Expressive-Culture.html.

Adventist Frontier Missions. "Himba Frontier Missions.” Accessed December 2, 2016. http://www.afmonline.org/serve/detail/himba.

. "Who We Serve." Accessed December 2, 2016. http://www.afmonline.org /serve/projects/all.

Ajaero, Chukwuedozie K., and Patience C. Onokala. "The Effects of Rural-Urban Migration on Rural Communities of Southeastern Nigeria." International Journal of Population Research (2013). Accessed November 22, 2016. http://dx.doi.org/ 10.1155/2013/610193.

Albin, Rabbi B. A Spiritual History of the Western Tradition. Raleigh, NC: Lulu, 2008.

All Africa. "Kenya: Missionary Starts Radio Communication with Nomads.” Accessed November 13, 2016. http://allafrica.com/stories/200409240854.html.

Anderson, James N. "The Importance of Worldview-Awareness." Crossway, January 24, 2014. 
Andrews University. "Research Integrity and Compliance." The Andrews University Institutional Review Board. Office of Research and Creative Scholarship. Accessed April 22, 2016. http://www.andrews.edu/services/research/research_ compliance/.

Anglican Church of Kenya. "The Church History.” Accessed September 1, 2016. http://www.ackenya.org/ack/history.html.

Apeh, John E. Social Structures and Church Planting. Shippensburg, PA: Companion, 1989.

Appiah, Anthony, and Henry Louis Gates. Encyclopedia of Africa. Oxford, UK: Oxford University, 2010.

Ashford, Bruce. Theology and Practice of Mission: God, the Church, and the Nations. Nashville, TN: B and H, 2011.

Atwell, James. The Sources of the Old Testament: A Guide to the Religious Thought of the Hebrew Bible. New York: T and T Clark International, 2004.

Ausenda, Giorgio, ed. After Empire: Towards an Ethnology of Europe's Barbarians. San Francisco, CA: Boydell, 2002.

Babione, Carolyn. Practitioner Teacher Inquiry and Research. San Francisco, CA: Jossey-Bass, 2015.

Baker, Ann C. Catalytic Conversations: Organizational Communication and Innovation. Armonk, NY: M.E. Sharpe, 2010.

Baker, Jonathan, and Tade Akin Aina. The Migration Experience in Africa. Uppsala, Sweden: Nordic Africa Institute, 1995.

Barnard, Alan, and Jonathan Spencer. “Africa: Nilotic.” Encyclopedia of Social and Cultural Anthropology. New York: Routledge, 2002.

Barton, Cliff. "Missionary Spotlight-Kenya, Reaching the Pokot People." Evangelical Times: Christian News and Comments, November 2007. Accessed December 23, 2016. http://www.evangelical-times.org/archive/item/2657/Kenya/MissionarySpotlight---Kenya-reaching-the-Pokot-people/.

Baumann, Eddie Karl. Worldview as Worship: The Dynamics of a Transformative Christian Education. Eugene, OR: Wipf and Stock, 2011.

Bauer, Bruce L. "Congregational and Mission Structures and How the Seventh-day Adventist Church Has Related to Them." DMiss diss., Fuller Theological Seminary, 1992. 
. "The Importance of Worldview Change in the Discipling Process." Journal of Adventist Mission Studies 12, no. 2 (2016): 184-193.

. "Intercessory Prayer and Mission." Journal of Adventist Mission Studies 11, no. 1 (2015): 34-41.

Beine, David. "The End of Worldview in Anthropology." SIL International, 2010. Accessed October 29, 2016. http://www.sil.org/silewp/2010/silewp2010-004.pdf.

Benedict, Ruth. Patterns of Culture. New York: Mariner Books, 2005.

Bevans, Stephen B. Mission \& Culture: The Louis J. Luzbetak Lectures. Maryknoll, NY: Orbis Books, 2012. . Models of Contextual Theology. Maryknoll, NY: Orbis Books, 2002.

Bevans, Stephen B., Roger P. Schroeder, and Roger Schroeder, Constants in Context: A Theology of Mission for Today. Maryknoll, NY: Orbis Books, 2004.

Bianco, Barbara. "The Historical Anthropology of a Mission Hospital in Northwestern Kenya.” PhD diss., New York University, 1992.

Bible Study Tools. "Matthew 9:37-38." John Gill's Exposition of the Bible. Accessed September 10, 2016. http://www.biblestudytools.com/commentaries/gillsexposition-of-the-bible/matthew-9-38.html.

Billings, Todd J. The Word of God for the People of God: An Entryway to the Theological Interpretation of Scripture. Grand Rapids, MI: Eerdmans, 2010.

Bliss, George R. Commentary on the Book of Luke. An American Commentary on the New Testament (ACNT). Edited by Alvah Hovey. Philadelphia, PA: American Baptist, 1881.

Boissoneault, Lorraine. "The World's Last Wanderers: 10 Nomadic Peoples." The Weather Channel. September 3, 2013. Accessed November 27, 2016. http://www .weather.com/travel/news/worlds-last-wanderers-10-nomadic-peoples$20130828 \# / 5$.

Bollig, Michael. "An Outline of Pre-Colonial Pokot History." Afrikanistische Arbeitspapiere, no. 23 (1990): 73-91.

. Risk Management in a Hazardous Environment: A Comparative Study of Two Pastoral Societies. New York: Springer Science and Business Media, 2006. 
. "Staging Social Structures: Ritual and Social Organization in an Egalitarian Society: The Pastoral Pokot of Northern Kenya." Ethnos: Journal of Anthropology 65, no. 3 (2000).

Bollig, Michael, Michael Schnegg, and Hans-Peter Wotzka. Pastoralism in Africa: Past, Present and Future. New York: Berghahn Books, 2013.

Bosch, David J. Transforming Mission: Paradigm Shifts in Theology of Mission. Maryknoll, NY: Orbis, 2011.

Botha, Phillip. Demonology: Demons and Devils /Spiritual Warfare. Raleigh, NC: Lulu, 2912.

Boundless Political Science. "Motivations behind the Formation of Interest Groups." Accessed April 20, 2016. https://www.boundless.com/political-science/textbooks /boundless-political-science-textbook/interest-groups-7/interest-groups47/motivations-behind-the-formation-of-interest-groups-280-3551/.

Caldarola, Carlo. Religion and Societies: Asia and the Middle East. Berlin, Germany: Walter de Gruyter and Company, 1982.

Chatty, Dawn. Nomadic Societies in the Middle East and North Africa: Entering the 21st Century. Leiden, Netherlands: Brill Academic, 2006.

Cheong, John. "Reassessing John Stott's, David Hesselgrave's, and Andreas Köstenberger's Views of the Incarnational Model.” In Missionary Methods: Research, Reflections, and Realities, edited by Craig Ott and J. D. Payne, 39-60. Pasadena, CA: William Carey Library, 2013.

Chesaina, Ciarunji, and Ciarunji Chesaina Swinimer. The Pokot. The Heritage Library of African Peoples. New York: The Rosen, 1994.

Chey, Loh Hung. "The Change Process." In Transforming into Christlikeness, 67-72. Guildford, UK: Genesis Books, 2011.

Claydon, David. A New Vision, a New Heart, a Renewed Call. Pasadena, CA: William Carey Library, 2005.

Cohen, Selma Jeanne, ed. International Encyclopedia of Dance. Oxford, UK: Oxford University, 1998.

Collins Dictionary. s.v. "Worldview." Accessed October 13, 2014. http://www .collinsdictionary.com/dictionary/english/weltanschauung\#weltanschauung_1.

Comboni Missionaries. "South Sudan." Accessed December 22, 2016. http://www. combonisouthsudan.org/. 
Comboni Missionaries in Kenya. "Kacheliba." Accessed December 22, 2016. http://kenyacomboni.org/.

Conant, Francis P. "Frustration, Marriage Alternatives, and Subsistence Risks among the Pokot of East Africa: Impressions of Co-Variance.” Anthropological Quarterly, 47, no. 3 (July 1974): 314-327.

Corbitt, Nathan J. The Sound of the Harvest: Music's Mission in church and Culture. Grand Rapids, MI: Baker Books, 1988.

. "Korok: A Variable Unit of Physical and Social Space among the Pokot of East Africa." American Anthropologist 67, no. 2 (1965): 429-434.

County Government of West Pokot. "First County Integrated Development Plan 20132017.” Accessed July 31 2016. www.westpokot.go.ke/docs/CIDPfinaldraft.docx.

Craig Ott, Stephen J. Strauss, and Timothy C. Tennent, Encountering Theology of Mission: Biblical Foundations, Historical Developments, and Contemporary Issues (Grand Rapids, MI: Baker Books, 2010.

Creswell, John W. Qualitative Inquiry and Research Design: Choosing among Five Approaches. Thousand Oaks, CA: Sage, 2013.

Dabrowski, Rajmund, ed. Seventh-day Adventist Church Statements, Guidelines and Other Documents. Hagerstown, MD: Review and Herald, 2010.

Dalton, Dave. People on the Move: Nomads and Travelers. Chicago: Heinemann, 2006.

Dana, Robert L. Christian Mission: How Christianity Became a World Religion. West Sussex, UK: John Wiley and Sons, 2011.

Davies, Art. From Foot Safaris to Helicopters: 100 Years of the Davis Family in Missions. Bloomington, IN: iUniverse, 2011.

De Oliveira, Paulo Candido. "Developing an Interdisciplinary Analysis and Application of Worldview Concepts for Christian Mission." PhD dissertation, Andrews University, 2006.

De Vries, Kim. "Identity Strategies of the Agro-Pastoral Pokot: Analyzing Ethnicity and Clanship within a Spatial Framework." Master's thesis, University of Amsterdam, 2007.

DeWalt, Kathleen M., and Billie R. DeWalt. Participant Observation: A Guide for Fieldworkers. Lanham, MD: AltaMira, 2011. 
Dicks, Ian D. An African Worldview: The Muslim Amacinga Yawo of Southern Malawi. Zomba, Malawi: Kachere Series, 2012.

Dillon, Christine. Telling the Gospel through Story: Evangelism That Keeps Hearers Wanting More. Downers Grove, IL: InterVarsity, 2012.

Dockery, David. “A God-centered Worldview.” Accessed December 10, 2016. https:// www.gospelproject.com/2013/10/21/the-importance-of-a-christian-worldview/.

Dosumu, Paul A. "Missiological Study of the Phenomenon of Dual Allegiance in the Seventh-day Adventist Church among the Yorba People of Nigeria." PhD diss., Andrews University, 2010.

Douglas, Mary. Natural Symbols: Explorations in Cosmology. New York: Taylor and Francis, 2004.

Drani, Emily D. "Synergy between Modern and Traditional Governance Mechanisms Experiences from Uganda." Mashariki: Culture and Peace Building Journal 1, no. 1 (2014).

Dryden, J. de Waal. Theology and Ethics in 1 Peter: Paraenetic Strategies for Christian Character Formation. Tubingen, Germany: Mohr Siebeck, 2006.

Dyer, Nat, Shadrack Omondi, and Michael Wantsusi. Securing Pastoralism in East and West Africa: Protecting and Promoting Livestock Mobility. London: International Institute for Environment and Development, 2008.

Dyrness, William A. and Veli-Matti Kärkkäinen, eds. Global Dictionary of Theology: A Resource for the Worldwide Church. Downers Grove, IL: InterVarsity, 2008.

Edgerton, Robert B. "Pokot Intersexuality: An East African Example of the Resolution of Sexual Incongruity." American Anthropologist 66, no. 6 (October 28, 2009).

Edgerton Robert B., and Francis Conant. "Kilapat: The Shaming Party among the Pokot of East Africa." Southwestern Journal of Anthropology, 20, no. 4 (1964): 404418.

Ehret, Christopher. "Outlining Southern African History: A Re-evaluation A.D. 1001500.” Ufahamu: A Journal of African Studies 1, no. 3 (1972): 9-28.

Elliston, Edgar J. Introduction to Missiological Research Design. Pasadena, CA: William Carey Library, 2011.

Encyclopedia Britannica. s.v. "Nomadism.” Accessed November 4, 2016. http://www .britannica.com/EBchecked/topic/417292/nomadism. 
Evans, Steven A. "Communicating Christ in a Cross-Cultural Context: Developing Effective Media and Communication Strategies Leading to Church Planting Movements. 2004." Accessed November 23, 2016. www.reachingandteaching.org /wp-content/uploads/sites/8/2014/06/WorldofOrality.pdf.

. "Orality, Story and Cultural Transformation: The Critical Role of Storytelling in Affecting Worldview and Values.” Accessed July 31, 2016. http://gnhmovement.org/papers/evans.pdf.

Exell, Joseph S. “Commentary on Genesis 12:1-3.” The Biblical Illustrator. Grand Rapids, MI: Baker Books, 1954.

Fecha, Aboutalib. "Best Practices for Reaching Pastoral Nomads." Lausanne Movement. Accessed December 23, 2016. http://lausanne.org/uploads/resources/files/11281.

Ferraro, Gary, and Susan Andreatta. Cultural Anthropology: An Applied Perspective. Stamford, CT: Cengage Learning, 2014.

Fitzpatrick, Mary, Tim Bewer, and Matthew Firestone. East Africa. Melbourne, Australia: Lonely Planet, 2009.

Fleischman, Jennifer R. "Beads of Empowerment: The Role of Body Art in Challenging Pokot Gender Identities.” Master's thesis, Georgia State University, 2012.

Flemming, Dean. Recovering the Full Mission of God: A Biblical Perspective on Being, Doing, and Telling. Downers Grove, IL: InterVarsity Press, 2013.

Fox, John. "Pokot Beliefs about Death." CNN, October 20, 1998. Accessed December 12, 2016. http://www.cnn.com/TECH/science/specials/africaquest/week3/.

Fratkin, Elliot, Martha A. Nathan, and Eric Abella Roth. "Is Settling Good for Pastoralists?” Accessed October 23, 2016. http://www.saga.cornell.edu/saga /ilri0606/23presentation.pdf.

Fratkin, Elliot, and Eric Abella Roth. As Pastoralists Settle: Social, Health, and Economic Consequences of the Pastoral Sedentarization in Marsabit District, Kenya. New York: Plenum, 2006.

Free Dictionary. s. v. "Nomad.” Accessed July 3, 2016. http://www.thefreedictionary .com/nomad.

Frost, Michael, and Alan Hirsch. The Shaping of Things to Come: Innovation and Mission for the 21st-Century Church. Grand Rapids, MI: Baker Books, 2013.

Fyock, James A. "The Effect of the Teacher's Worldviews on the Worldviews of High School Seniors." PhD diss., Liberty University, 2008. 
Galaty, John. "Dreams, Symbols, and Totems." New Internationalist Magazine, April 5, 1995. Accessed October 2, 2016. http://newint.org/features/1995/04/05/dreams/.

General Conference of Seventh-day Adventists. "Adventist World Statistics." Office of Archives, Statistics and Research. Accessed October 17, 2016. http://www. adventiststatistics .org/view_Summary.asp?FieldInstID=2066644.

. "Mission Statement of the Seventh-day Adventist Church." October 13, 2014. Accessed November 19, 2016. http://www.adventist.org/information/officialstatements/statements/article/go/0/mission-statement-of-the-seventh-dayadventist-church/.

. "Roadmap for Mission." Seventh-day Adventist Church, October 13, 2009. Accessed September 31, 2016. https://www.adventist.org/en/information/officialstatements/documents/article/go/-/roadmap-for-mission/.

. Seventh-day Adventists Believe. Silver Spring, MD: General Conference of Seventh-day Adventists, 2005.

Gilbert, Jérémie. Nomadic Peoples and Human Rights. New York: Routledge, 2014.

Gilliland, Dean S. “Contextualization.” Evangelical Dictionary of World Religions. Grand Rapids, MI: Baker Books, 2000.

. "The Incarnation as Matrix for Appropriate Theologies." In Appropriate Christianity, edited by Charles H. Kraft, 493-519. Pasadena, CA: William Carey Library, 2005.

Glasser, Arthur F., Charles E. Van Engen, Dean S. Gilliland, and Shawn B. Redford. Announcing the Kingdom: The Story of God's Mission in the Bible. Grand Rapids, MI: Baker Books, 2003.

Glesne, Corrine. Becoming Qualitative Researchers: An Introduction. London: Longman, 1999.

Godwyll, Francis E. "Migration of Ethnic Groups." In Cultural Sociology of the Middle East, Asia, and Africa: An Encyclopedia, edited by Andrea L. Stanton, 36-37. Washington, DC: Sage, 2012.

Goergen, Donald J. The Mission and Ministry of Jesus. Eugene, OR: Wipf and Stock, 2003.

The Government of Kenya. "Policy Framework on Nomadic Education in Kenya." Accessed October 1, 2016. http://planipolis.iiep.unesco.org/upload/Kenya/Kenya PolicyFrameworkNomadicEducation.pdf. 
Graham, Bruce. "Transforming Worldviews Through the Biblical Story." In Perspectives on the World Christian Movement, 4th ed., edited by Ralph D. Winter and Steve C. Hawthorne, 442-443. Pasadena, CA: William Carey Library, 2009.

Grant, Richard. American Nomads: Travels with Lost Conquistadors, Mountain Men, Cowboys, Hoboes, Truckers, and Bullriders. New York: Grove, 2003.

Greer, Ivor C. "Orality and Christian Discipleship: Developing A 'Living' Word.” PhD diss., Bangor University, 2008.

Gregory, Neville G., and Temple Grandin. Animal Welfare and Meat Production. Cambridge, MA: CAB International, 2007.

Hale, Tom, and Steve Thorson. "1 John 4: 7-21." Applied NT Bible Commentary. Colorado Springs, CO: David C. Cook, 2012.

Harvesters International. "Chemolingot Children's Home." Accessed December 23, 2016. https://harvesters.net/chemolingot-childrens-home/.

Haviland, William A., Harald E. L. Prins, and Bunny McBride. Cultural Anthropology: The Human Challenge. Belmont, CA: Cengage, 2011.

Hayward, Douglas J. "Ministry to Non-industrialized Peoples: A Selected Bibliography." Internal Journal of Frontier Missions 14, no. 4 (October-December 1997): 189199.

Healey, Joseph G. African Stories for Preachers and Teachers. Nairobi, Kenya: Paulines Publications Africa, 2005.

Hesselgrave, David J. Communicating Christ Cross-Culturally. 2nd ed. Grand Rapids, MI: Zondervan House, 1991.

. Planting Churches Cross-Culturally: North America and Beyond. Grand Rapids, MI: Baker Books, 2000.

. "The Role of Culture in Communication." In Perspectives on the World Christian Movement, edited by. Ralph D. Winter and Steven C. Hawthorne, 425429. Pasadena, CA: William Carey Library, 2009.

Hiebert, Paul G. Anthropological Insights for Missionaries. Grand Rapids, MI: Baker Books, 2001. . The gospel in Human Contexts: Anthropological Explorations for Contemporary Missions. Grand Rapids, MI: Baker Books, 2009. 
. Incarnational Ministry: Planting Churches in Band, Tribal, Peasant, and

Urban Societies. Grand Rapids, MI: Baker Books, 1995.

. Transforming Worldviews: An Anthropological Understanding of How People

Change. Grand Rapids, MI: Baker Books, 2008.

Hiebert Paul G., R. Daniel Shaw, and Tite Tienou. Understanding Folk Religion: A

Christian Response to Popular Beliefs and Practices. Grand Rapids, MI: Baker

Books, 1999.

Hiernaux, Pierre. The Crisis of Sahelian Pastoralism: Ecological or Economic? Addis Ababa, Ethiopia: International Livestock Centre for Africa, 1996.

Hirsh, Allan. The Forgotten Ways: Reactivating the Missional Church. Grand Rapids, MI: Baker Books, 2006.

Hirsh, Allan, and Debra Hirsh. Untamed: Reactivating a Missional Form of Discipleship. Grand Rapids, MI: Baker Books, 2010.

Holste, Scott J. "Finishing the Task." In Best Missional Practices for the 21 st Century: Discovering the Mission of God. Downers Grove, IL: InterVarsity, 2012.

Honer, Mary. Missy Fundi: Kenya Girl. Lincoln, NE: iUniverse, 2003.

Hope, Kempe R. "Decentralization and Local Governance.” In The Political Economy of Development in Kenya, 152-165. New York: Continuum, 2011.

Howell, Brian M., and Jenell Williams, Introducing Cultural Anthropology: A Christian Perspective. Grand Rapids, MI: Baker Books, 2011.

Hunter III, George G. “The Legacy of Donald A. McGavran.” International Bulletin of Missionary Research no. 4 (October 1992): 61-72.

Hunter, Malcolm J. “The Challenge of Reaching Nomadic Pastoralists.” International Journal of Frontier Missions 14, no. 4 (October-December, 1997): 183-190.

. "The Nomadic Church: The Church in Its Simplest Form." International Journal of Frontier Missions 17, no. 3 (Fall 2000): 7-16.

. "Think Nomadic." International Journal of Frontier Missions 17, no. 2 (Summer 2000): 9-13.

. "Who Are These Nomadic People and Why Bother about Them?" Nomadic Peoples Network, August 2011. Accessed November 1, 2016. http://nomadic peoples.net. 
Imana, Aletia C. Goat Rearing as a Livelihood Strategy of Turkana: Pastoralism in North West Kenya. PhD diss., University of The Free State, 2008.

International Institute for Environment and Development. "Education for Nomads." Accessed December 19, 2016. http://www.iied.org/education-for-nomads.

International Orality Network. "Making Disciples of Oral Learners." In Perspectives on the World Christian Movement, 4th ed., edited by Ralph D. Winter and Steven C. Hawthorne, 437-439. Pasadena, CA: William Carey Library, 2009.

IRIN. "Kenya: The Dangers of Pastoralism.” Accessed January 10, 2016. http://www .irinnews.org/Report/85252/KENYA-The-dangers-of-pastoralism.

. "Kenya: Drought Exacerbating Conflict among Pastoralists." Accessed December 10, 2016. http://www.irinnews.org/Report/82683/KENYA-Droughtexacerbating-conflict-among-pastoralists.

"Uganda: FGM among the Pokot Heightens HIV Risk." Accessed July 31, 2016, http://www.irinnews.org/indepthmain.aspx?InDepthID=15\&ReportID $=59941$.

James, Alton R. "Post Reformation Missions Pioneers." In Discovering the Mission of God: Best Missional Practices for the 21st Century, edited by Mike Barnett, 250265. Downers Grove, IL: InterVarsity, 2012.

Jenkins, Orville Boyd. "What Is a People Group?” Accessed December 22, 2016. http:// public.imb.org/globalresearch/Pages/PeopleGroup.aspx.

Johnson, Nancy, and Ayago Wambile, eds. "The Impacts of the Arid Lands Resource Management Project (ALRMPII) on Livelihoods and Vulnerability in the Arid and Semi-Arid Lands of Kenya." International Livestock Research Institute, 2011.

Jónsson, Kjartan. "Pokot Masculinity: The Role of Rituals in Forming Men." PhD diss., University of Iceland, 2007.

Jordan, Michael. Dictionary of Gods and Goddesses. New York: InfoBase, 2014.

Joshua Project. Accessed January 31, 2016. http://www.joshuaproject.net/countries .php?rogs=UV.

. "Kalenjin, Pokot in Kenya." The Joshua Project. Accessed December 3, 2015, https://joshuaproject.net/people_groups/14428/KE.

Kahn, Robert L., and Charles F. Cannell. The Dynamics of Interviewing: Theory, Technique, and Cases. DeKalb, IL: John Wiley, 1957. 
Kawulich, Barbara B. "Participant Observation as a Data Collection Method." Forum Qualitative Research 6, no. 2 (May 2005). Accessed December 3, 2016. http://www.qualitative-research.net/index.php/fqs/article/view/466/996.

Kearney, Michael. World View. Novato, CA: Chandler \& Sharp, 1984.

Keidel, Paul. Career-defining Crises in Mission: Navigating the Major Decisions of Cross-cultural Service. Pasadena, CA: William Carey Library, 2013.

Kelleher, Fatimah. "Reaching Nomadic Communities: Providing Inclusive Quality Education." Commonwealth Education Partnership 2007. Accessed October 21, 2016. www.cedol.org/wp-content/uploads/2012/02/65-67-2007.pdf.

Kerrow, Billow. "Census Circus and the Need to Independently Audit Results." East Africa Standard Digital, September 5, 2010. Accessed September 24, 2016. http://www.standardmedia.co.ke/?id=2000017690\&catid=612\&articleID=200001 7690 .

Kim, Hansoo. "Oregon Koreans Minister in Kenya." GleanerNow. September 1, 2006. Accessed September 22, 2015. http://gleanernow.com/news/2006/09/oregonkoreans-minister-kenya.

Kipuri, Naomi. "Indigenous Peoples' Rights to Lands, Territories and Resources Related to Discrimination in Employment and Occupation: Case Study on Practices of Pastoralism and Hunting-Gathering in Kenya." The International Labor Organization, February 2008.

Kituku, Vincent wa Muli. East African Folktales: From the Voice of Mukamba. Little Rock, AR: August House, 1997.

Kiyapyap, Francis. Comment, July 15, 2015 (4:04 am) on "Pokot Religion and Expressive Culture.” Accessed July 8, 2016. http://www.everyculture .com/Africa-Middle-East/Pokot-Religion-and-Expressive-Culture.html.

Koltko-Rivera, Mark E. “The Psychology of Worldviews." American Psychological Association Review of General Psychology 8, no. 1 (2004).

. "The Worldview Assessment Instrument (WAI): The Development and Preliminary Validation of an Instrument to Assess Worldview Components Relevant to Counseling and Psychotherapy." PhD diss., New York University, 2000 .

Kraft, Charles H. Anthropology for Christian Witness. Maryknoll, NY: Orbis Books, 2004.

. Christianity in Culture: A Study in Dynamic Biblical Theologizing in Cross Cultural Perspective. Maryknoll, NY: Orbis Books, 1979. 
. Christianity with Power: Your Worldview and Your Experience of the Supernatural. Ann Arbor, MI: Servant, 1989.

. Communication Theory for Christian Witness. Maryknoll, NY: Orbis Books, 1991.

. Culture, Communication, and Christianity: A Selection of Writings. Pasadena, CA: William Carey Library, 2001.

. Worldview for Christian Witness. Pasadena: CA: William Carey Library, 2008.

Krätli, Saverio, and Jeremy Swift. "Counting Pastoralists in Kenya.” Disaster Risk Reduction: East and Central Africa. Accessed September 6, 2016. http://www.fao .org/disasterriskreduction/east-central-africa/documents/detail/en/c/4148/.

Kuhn, Wagner. Redemptions and Transformation through Relief and Development: Biblical, Historical and Contemporary Perspectives of God's Holistic Gospel. Benton Harbor, MI: Patterson, 2013.

Lamphear, John. Encyclopedia of African History. Edited by Kevin Shillington. New York: Fitzroy Dearborn, 2005.

Landtman, Gunnar. The Origin of the Inequality of the Social Classes. New York: Routledge, 2016.

Langmead, Ross. The Word Made Flesh: Towards an Incarnational Missiology. Lanham, MD: University Press, 2004.

LeCompte, Margaret D. and Jean J. Schensul. Analysis and Interpretation of Ethnographic Data: A Mixed Methods Approach. Plymouth, UK: AltaMira, 2013.

. Designing and Conducting Ethnographic Research: An Introduction. Lanham, MD: AltaMira, 2010.

Levinson, David. Encyclopedia of World Cultures: Africa and the Middle East. Boston, MA: G. K. Hall, 1995.

Lewis, Jonathan, ed. World Mission: An Analysis of the World Christian Movement. Pasadena, CA: William Carey Library, 1994.

Lichtenwalter, Larry L. "Worldview Transformation and Mission: Narrative, Theology, and Ritual in John's Apocalypse." Journal of the Adventist Theological Society, 21, nos. 1-2 (2010): 211-219. 
Lipovsky, Igor P. “At the Sources of Biblical History.” Accessed September 22, 2016. http://www.biblicaltheology.com/Research/LipovskyIP02.pdf.

Lodico, Marguerite G., Dean T. Spaulding, and Katherine H. Voegtle. Methods in Educational Research: From Theory to Practice. San Francisco, CA: JosseyBass, 2010.

Lokwei, Immanuel, ed. "Conflict and Cultural Change, The Pokots." Long Mouth Social Commune, May 22, 2012. Accessed December 22, 2016. http://longmouthsocial commune.org/2012/05/22/chapter-6-conflict-and-cultural-change-the-pokots/.

Lopetakou, William. Interview by Author. Kapenguria, West Pokot, June 15, 2014.

Lucie-Smith, Alexander, ed. Mission Ad Gentes: The Challenge for the Church in Kenya. Occasional paper no. 21. Nairobi, Kenya: Paulines, 2007.

Makong'o, Julius, and Kizito Muchanga. Peak Revision K.C.S.E. History \& Government. Nairobi, Kenya: East African Educational, 2006.

Makumba, Maurice M. "Philosophy and African Traditional Religions." In An Introduction to African Philosophy: Past and Present, 163-176. Nairobi, Kenya: Paulines, 2007.

Mandryk, Jason. Operation World: The Definitive Prayer Guide to Every Nation. Colorado Springs, CO: Jason Mandryk and GMI, 2010.

Maro, Zakaria Godson, Peter Ngatia Nguura, and Jemal Yousuf Umer. Understanding Nomadic Realities: Case Studies on Sexual and Reproductive Health and Rights in Eastern Africa. Nairobi, Kenya: KIT Publishers, 2012.

May, Stan. "Cultures and Worldviews" In Best Missional Practices for the 21 st Century: Discovering the Mission of God, edited by Mike Barnett, 377-390. Downers Grove, IL: InterVarsity, 2012.

Mbiti, John S. African Religions and Philosophy. Portsmouth, NH: Heinemann, 1990.

McElhanon, Ken A. "Worldview." Evangelical Dictionary of World Religions." Grand Rapids, MI: Baker Books, 2000.

McGavran, Donald A. The Bridges of God. London: World Dominion, 1955. . Understanding Church Growth. Grand Rapids, MI: William B. Eerdmans, 1990.

Mcllwain, Trevor. Firm Foundations: From Creation to Christ. Sanford, FL: New Tribes Mission, 2009. 
Merriam-Webster Dictionary. s.v. "Nomad." Accessed July 13, 2016. http://www .merriam-webster.com/dictionary/nomad.

. s.v. "Worldview." Accessed October 13, 2014. http://www.merriamwebster.com/dictionary/worldview.

Meyerhoff, Elizabeth L. "The Socio-economic and Ritual Roles of Pokot Women.” PhD diss., Cambridge University, 1982.

Moreau, Scott A. Contextualization in World Missions: Mapping and Assessing Evangelical Models. Grand Rapids, MI: Kregel, 2012.

Moreau, Scott A., Evvy Hay Campbell, and Susan Greener. Effective Intercultural Communication (Encountering Mission): A Christian Perspective. Grand Rapids, MI: Baker Books, 2014.

Modola, Siegfried. "Rites of Manhood." Reuters: The Wider Image. February 11, 2016. Accessed August 12, 2016. https://widerimage.reuters.com/story/rites-ofmanhood.

Moon, Jay W. African Proverbs Reveal Christianity in Culture: A Narrative Portrayal of Builsa Proverbs Contextualizing Christianity in Ghana. Eugene, OR: Pickwick, 2009.

. "Discipling through the Eyes of Oral Learners." Missiology 28, no. 2 (2010). Accessed October 1, 2016. http://mis.sagepub.com/content/38/2/127 .full.pdf.

Moon, Jennifer A. Using Story to Enrich Learning and Teaching: In Higher Education and Professional Development. New York: Routledge, 2010.

Morgan, Clyde. "East-Central Africa Division Unreached Assessment Report." Unpublished manuscript, April 22, 2010.

Moskala, Jirí. "The Mission of God's People in the Old Testament." Perspective Digest 16, no 2 (2008). Accessed December 5, 2016. http://www.perspectivedigest.org /article/38/archives/16-2/mission-of-god-s-people-in-the-old-testament.

Muchanga, Kizito. History andGovernment. Nairobi, Kenya: East Africa Educational, 2006.

Müller, Nicole, and Martin J. Ball, eds. Analyzing Casual Conversation. New York: Wiley and Sons, 2013.

Munene, Karega. Holocene Foragers, Fishers and Herders of Western Kenya. Lansing, MI: University of Michigan, 2002. 
Murchison, Julian. Ethnography Essentials: Designing, Conducting, and Presenting Your Research. San Francisco, CA: Jossey-Bass, 2015.

Mutsotso, Beneah Manyuru. "Conflict and Social Change: The East Pokot Pastoralists Adjustment to Conflict." American International Journal of Social Science 2, no. 8 (December 2013): 121-142.

. "The Centrality of Cattle in the Social Organization of the East Pokot Pastoralists of North Western Kenya." European Scientific Journal 10, no. 8 (March 2014): 497-507.

MVUA- Missionary Volunteers to Unentered Areas. "What We Do." Accessed October 5, 2016. http://www.mvua.or.ke/index.php/what-we-do.

Mwakikagile, Godfrey. The People of Kenya and Uganda. Dar es Salaam, Tanzania: New Africa, 2014.

Mwaniki, Terry, Peter Mbuchi, Marl Leleruk, and Fred Mwei. Conflict Management: Joint Case Study of North Rift Region of Kenya. Nairobi, Kenya: Paulines, 2007.

Myers, Bryant L. Walking with the Poor: Principles and Practices of Transformational Development. Maryknoll, NY: Orbis Books, 1999.

Nangulu, Anne Kisaka. Food Security and Coping Mechanisms in Marginal Areas: The Case of West Pokot, Kenya, 1920-1995. Leiden, Netherlands: African Studies Centre, 2009.

Nasambu, Tabitha. Chepararia SDA Clinic Nurse in-charge. Interview by Author. Chepararia, West Pokot, June 25, 2014.

Naugle, David K. Worldview: The History of a Concept. Grand Rapids, MI: William B. Eerdmans, 2002.

Naylor, Larry L. Culture and Change: An Introduction. Westport, CT: Bergin and Garvey, 1996.

Ndegwah, David J. Biblical Hermeneutics as a Tool for Inculturation in Africa: A Case Study of the Pokot People of Kenya. Charlotte, NC: Creations Enterprises, 2007.

Nelson, Sarah M. Identity and Subsistence: Gender Strategies for Archaeology. Lanham, MD: AltaMira, 2007.

New Internationalist. "The Facts.” April 5, 1995. Accessed November 18, 2016. http://newint.org/features/1995/04/05/facts/. 
New World Encyclopedia. s.v. "Nomad." Accessed December 18, 2016. http://www .newworldencyclopedia.org/entry/Nomad.

Nganga, Daniel. "Culture as the Cause of Conflict. A Case Study in West Pokot District, Kenya." In Fact-is Pax 6, no. 1 (2012): 51-69.

Nida, Eugene A. God's Word in Man's Language. New York: Harper and Row, 1952.

Nomadic Peoples Network. "Defining Nomadic Pastoralists." Accessed November 18, 2016. http://nomadicpeoples.net/defining-nomadic-pastoralists/.

. "What Is the Nomadic Peoples Network?” Accessed July 1, 2016. http:// nomadicpeoples.net/what-is-the-nomadic-peopls-network/.

Nthamburi, Zablon, and Douglas Waruta. "Biblical Hermeneutics in African Instituted Churches." In The Bible in African Christianity: Essays in Biblical Theology, edited by H. W. Kinoti and J. M. Waliggo, 140-155. Nairobi, Kenya: Acton, 1997.

Nyaundi, Nehemiah M. Religion and Social Change: A Sociological Study of Seventhday Adventism in Kenya. Lund, Sweden: Lund University, 1993.

Oba, Gufu, and Walter J. Lusigi. An Overview of Drought Strategies and Land Use in African Pastoral Systems. London: Overseas Development Institute Agricultural Administration Unit, 1987.

Obika, Julaina, A., and Harriet K. Bibangambah. "Climate Change and Peacebuilding among Pastoralist Communities in Northeastern Uganda and Western Kenya." In Conflict and Peacebuilding in the African Great Lakes Region, edited by. Kenneth Omeje and Tricia Redeker Hepner, 141-160. Bloomington, IN: Indiana University, 2013.

O’Dempsey, T. J. “Traditional Belief and Practice among the Pokot People of Kenya with Particular Reference to Mother and Child Health: The Pokot People and their Environment.” Ann Trop Paediatr 2 (June 1988): 49-60.

Office of the Prime Minister. "Getting to the Hardest-to-teach: A Strategy to Provide Education to Nomadic Communities in Kenya, by Jeremy Swift.” March 2010. Accessed September 15, 2016. http://pubs.iied.org/pdfs/G02742.pdf.

Ogachi, Ibrahim O. Transforming Education and Development Policies for Pastoralist Communities in Kenya. Addis Ababa, Ethiopia: Organization of Social Science Research in Eastern and Southern Africa, 2011.

Ogola, Leandro O. "Human Security in Pastoralist Areas of Eastern Africa." African Security Review 19, no. 3 (2010): 27-40. 
Okindo, Joel. East-Central Africa Division. Interview by Author. Berrien Springs, MI, September 2, 2012.

Olson, Gordon C. What in the World Is God Doing: The Essentials of Global Missions: An Introductory Guide. Cedar Knolls, NJ: Global Gospel Publishers, 2003.

Olthuis, James H. “On Worldviews.” In Stained Glass: Worldviews and Social Sciences, edited by Paul A. Marshall, Sander Griffioen, S. Griffioen, and Richard J. Mouw, 26-40. Lanham, MD: University Press, 1989.

Omondi, Francis, and Orvill Boyd Jenkins. "The Borana of Ethiopia and Kenya." Strategy Reader Resource Kit. Accessed July 1, 2016. http://strategyleader.org /profiles/borana.html.

O’Neal, Sean S. Bridges to People: Communicating Jesus to People and Growing Missionary Churches in a Multi-Ethnic World. Maitland, FL: Xulon Press, 2007.

Ong, Walter J. "World as View and World as Event." American Anthropologist 71, no. 4 (November 1969): 641-643.

Onongha, Kelvin O. "Towards a Missiological Model for Worldview Transformation among Adherents to African Traditional Religion in Yorubaland." PhD diss., Andrews University, 2014.

Onunwa, Udobata R. A Handbook of Methodologies of African Studies. Pittsburgh, PA: Red Lead, 2010.

Österle, Matthias. "From Cattle to Goats: The Transformation of East Pokot Pastoralism in Kenya.” Nomadic Peoples 12, no. 1 (Summer 2008): 81-91.

Oswald, John. "Gospel Communication in Tibetan Song." In Communicating Christ Through Story and Song: Orality in Buddhist Contexts, edited by Paul H. De Neui, 237-272. Pasadena, CA: William Carey Library, 2008.

Ott, Craig, and Gene Wilson. Global Church Planting: Biblical Principles and Best Practices for Multiplicity. Grand Rapids, MI: Baker Books, 2011.

Oxford English Dictionary. s.v. "Worldview." Accessed October 13, 2014. http://www.oxforddictionaries.com/us/definition/

Parklea, Joseph. Interview by author. Kapenguria, West Pokot, June 12, 2014.

Parsons, Greg H. Lausanne' 74: Ralph D. Winter's Writings with Responses. Pasadena, CA: William Carey Library, 2015.

Patterson, David K. The Pokot of Western Kenya, 1910-1963: The Response of a Conservative People to Colonial Rule. Syracuse, NY: Syracuse University, 1969. 
Patton, Michael Q. Qualitative Research \& Evaluation Methods. Thousand Oaks, CA: Sage, 2002.

Paul, Lewis M. Ethnologue: Languages of the World. 16th ed. Dallas, TX: SIL International, 2009.

Pawar, Manohar S. Data Collecting Methods and Experiences: A Guide for Social Researchers. Elgin, IL: New Dawn, 2004.

Payne J. D. and John M. Terry, Developing a Strategy for Missions, Encountering Mission: A Biblical, Historical, and Cultural Introduction. Grand Rapids, MI: Baker Books, 2013.

Payne, Susan. "The Role of Prayer in Ministries Dependent upon Donations." Journal of Adventist Mission Studies 11, no. 1 (2015): 54-60.

Peek, Philip M., and Kwesi Yankah, eds. "The Bantu.” African Folklore: An Encyclopedia. New York: Routledge, 2004.

Peristiany, J. G. "The Age-Set System of the Pastoral Pokot: Mechanism, Function and Post-Sapana Ceremonies.” Africa, no. 21 (1951): 279-302.

Peters, George W. A Biblical Theology of Missions. Chicago: Moody, 1972.

Petersen, Gideon. "God Speaks in the Heart Language." Journal of Adventist Mission Studies 5, no. 1 (Fall 2009): 98-109.

. "Ministry to Nomads: A Comprehensive Missiological Approach." PhD diss., University of the Free State, 2011.

. "Training Oral Leaders: An Adventist Challenge." Journal of Adventist Mission Studies 5, no. 2 (Fall 2009): 86-96.

Petrakis, Panagiotis E. Culture, Growth and Economic Policy. New York: Springer, Science, and Business Media, 2014.

Phillips, David J. "Factors in Training Workers for Nomadic Peoples." International Journal of Frontier Missions 17, no. 3 (Fall 2000): 41-44.

Peoples on the Move: Introducing the Nomads of the World. Pasadena, CA: William Carey Library, 2004.

. "Peoples on the Move: It Is Past Time to Target the Neglected Nomads." Evangelical Missions Quarterly 35, no. 4 (1999): 410-417. 
. "The Need for a Nomadic Theology (Part One)." International Journal of

Frontier Missions 17, no. 2 (Summer 2000): 25-33.

. "Peoples on the Move: Toward Christ." International Journal of Frontier Missions 17, no. 2 (Summer 2000): 5-8.

. "Striking Camp with Nomads." Mission Frontiers, March 1, 2002. Accessed December 3, 2016. http://www.missionfrontiers.org/issue/article/striking-campwith-the-nomads?from_navigate=true.

Phillips, K. N. Tom Collins of Kenya: Son of Valour. Nappanee, IN: Evangel House, 2003.

Phiri, George A. Social-Cultural Anthropology: Christian Communication with the African Society. Eugene, OR: Resource, 2009.

Pierson, Paul E. The Dynamics of Christian Mission: History Through a Missiological Perspective. Pasadena, CA: William Carey Library, 2009.

Pkalya, Ruto, Mohamud Adan, and Isabella Masinde. Indigenous Democracy:

Traditional Conflict Resolution Mechanisms. Nairobi, Kenya: Greenwood, 2004.

Pleasance, Chris. "Young Women Dragged Away from Their Village for a Dowry of 20 Goats and 3 Camels: Inside the Traditional Tribal Wedding Ceremony That Still Takes Place in Kenya." Daily Mail, December 10, 2014. Accessed January 20, 2017. http://www.dailymail.co.uk/news/article-2868693/.

Poe, Samuel. "Bringing the Good News to Oral Cultures." Accessed November 2, 2016. http://www.newfrontierschurch.com/downloads/cbs/oralcultures.pdf.

Pokot Mission Project. “About-Pokot Mission Project.” Accessed October 21, 2016. http://pokotmission.blogspot.com/p/about.html.

"Pokot-Turkana Peace Initiative: Initial Findings and Recommendations." Pokot-Turkana Peace Initiative. Accessed November 11, 2016. http://www.pokotturkanapeace initiative.com/about.html.

. "We Are Your Orphans." Accessed January 22, 2016. http://www.pokot turkanapeaceinitiative.com/sponser-an-orphan.html.

Porter, Philip W., and David R. Faust. A World of Difference: Encountering and Contesting Development. New York: Guilford, 2009.

Powel, Mark A. "Shepherds." HarperCollins Bible Dictionary condensed ed. New York: HarperCollins, 2009. 
Pragya Kenya. "Conflict Assessment: Northern Kenya.” Accessed December 10, 2016. http://www.pragya.org/doc/Conflict_Assessment_Report.pdf.

Reed, Lyman E. Preparing Missionaries for Intercultural Communication: A Bi-cultural Approach. Pasadena, CA: William Carey Library, 1995.

Richardson, Don. Peace Child: An Unforgettable Story of Primitive Jungle Treachery in the 20th Century. Ventura, CA: Regal Books, 2005.

Ritchie, Jane, Jane Lewis, Carol M. Nicholls, and Rachel Ormston. Qualitative Research Practice: A Guide for Social Science Students and Researchers. New York: Sage, 2013.

Robb, John D. "Strategic Prayer." In Perspectives on the World Christian Movement: A Reader, edited by Ralph D. Winter and Steven C. Hawthorne, 163-169. Pasadena, CA: William Carey Library, 2009.

Rogers, Glenn. The Role of Worldview in Missions and Multiethnic Ministry. Dallas, TX: Mission and Ministry Resources, 2002.

Roller, Margaret R., and Paul J. Lavrakas. Applied Qualitative Research Design: A Total Quality Framework Approach. New York: The Guilford, 2015.

Rommen, Edward, and Gary Corwin, Missiology and the Social Sciences. Pasadena, CA: William Carey Library, 1996.

Rwezaura, B. A. "Changing Community Obligations to the Elderly in Contemporary Africa." Journal of Social Development in Africa 4, no. 1 (1989): 5-24.

Ryan, Patrick, ed. "Theology Inculturation in Africa: Methods, Praxis, and Mission." Paper presented at the Catholic University of East Africa, Nairobi, 2003. Quoted in Rhodian G. Munyenyembe, Christianity and Socio-cultural Issues: The Charismatic Movement and Contextualization in Malawi. Mzuzu, Malawi: Mzuni, 2011.

Samovar, Larry, Richard E. Porter, Edwin R. McDaniel, and Carolyn Sexton Roy. Communication between Cultures. 8th ed. Boston, MA: Cengage, 2013.

Sanchez, Daniel R. Introduction to Worldview: Implications for Missionary Work. Fort Worth, TX: Church Starting Network, 2013.

Sanou, Boubakar. "Responding Biblically and Missiologically to the Threat of Religious Syncretism." Journal of Adventist Mission Studies 9, no. 2 (2013): 94-109. 
Savageau, Cheryl, and Diane Stortz. Parents of Missionaries: How to Thrive and Stay Connected When Your Children and Grand Children Serve Cross-culturally. Colorado Springs, CO: Authentic, 2008.

Schensul, Stephen L., Jean J. Schensul, and Margaret Diane LeCompte, Essential Ethnographic Methods: Observations, Interviews, and Questionnaires. Lanham, MD: AltaMira, 1999.

Schneider, Harold K. The Africans: An Ethnological Account. Upper Saddle River, NJ: Prentice Hall, 1981.

. "Pakot Resistance to Change." In Continuity and Change in African Cultures, edited by William R. Bascom and Melville J. Herskovits, 154-162. Chicago, IL: University of Chicago, 1959.

. "The Pakot (Suk) of Kenya with Special Reference to the Role of Livestock in Their Subsistence Economy.” PhD diss., Northwestern University, 1953.

Schreier, Margrit. Qualitative Content Analysis in Practice. Washington, DC: Sage, 2012.

Schultz, Courtney. "Kenyan Pokot People Need Water: Christian Ministry." Baylor Lariat, August 22, 2005. Accessed December 25, 2016. http://www.baylor.edu /lariatarchives/news.php?action=story\&story $=35050$.

Seeger, Anthony. "Traditional Music in Community Life: Aspects of Performance, Recordings, and Preservation." Cultural Survival Quarterly Magazine (December 1996).

Seventh-day Adventist Church. "Why Global Mission." Pioneer Care Guide—Adventist Mission. Accessed November 9, 2016. http://adventistmission.genetadventist.org/ why-global-mission.

. SDA Church. General Conference Office of Archives, Statistics and Research. Accessed October 17, 2016, http://www.adventiststatistics.org/view _Summaryasp?FieldInstID=2066644.

Seventh-day Adventist Encyclopedia. Washington, DC: Review and Herald, 1976.

Shaffer, David Reed, and Katherine Kipp, Developmental Psychology: Childhood \& Adolescence. Belmont, CA: Cengage Learning, 2010.

Shanahan, Mike. "Media Perceptions and Portrayals of Pastoralists in Kenya, India, and China." International Institute for Environment and Development 154 (April 2013). 
Sheik-Mohamed, Abdikarim, and Johan P.Velema. "Where Health Care Has No Access: The Nomadic Populations of Sub-Saharan Africa." Tropical Medicine and International Health 4, no. 10 (October 1999): 695-707.

Sider, Ronald J. Good News and Good Works: A Theology for the Whole Gospel. Grand Rapids, MI: Baker Books, 1999.

Siele, David, Jeremy Swift, and Saverio Krätli. "Reaching Pastoralists with Formal Education: A Distance Learning Strategy for Kenya.” Paper presented at the International Conference on the Future of Pastoralism, Tufts University, March 21-23, 2011.

Sire, James W. Naming the Elephant: Worldview as a Concept. Downers Grove, IL: InterVarsity, 2004.

. The Universe Next Door. 5th ed. Downers Grove, IL: InterVarsity, 2009.

Smeets, Ineke. A Grammar of Mapuche. Berlin, Germany: Walter de Gruyter, 2008.

Smith, Rondal. "Strategy for World Evangelization." In Completing the Task: Reaching the World for Christ, edited by Edgar J. Elliston and Stephen E. Burris, 129-148. Joplin, MO: College Press, 1999.

Smith, Tom W. "Surveying Hard-to-Reach Populations in Comparative Perspective." University of Chicago GSS Cross-National Report, no. 33, November 2012. Accessed, July 31, 2016. publicdata.norc.org:41000/gss/documents/CNRT/CNR $\% 2033$.pdf.

Smither, Edward L. "Word and Deed." In Mission in the Early Church: Themes and Reflections, 127-147. Eugene, OR: Cascade Books, 2014.

Spencer, Paul. Nomads in Alliance: Symbiosis and Growth among the Rendile and Samburu of Kenya. New York: Oxford University Press, 1973.

Time, Space and the Unknown: Maasai Configurations of Power and Providence. New York: Routledge, 2003.

Southworld. "Kenya: Pokot, the Rite of Initiation: Sapana." September 1, 2014. Accessed December 20, 2016. http://www.southworld.net/kenya-pokot-the-rite-of-initiation -sapana/.

Spickard, Paul R., and Kevin M. Cragg, A Global History of Christians: How Everyday Believers Experienced Their World. Grand Rapids, MI: Baker Books, 2008.

Stanton, Andrea L., and Peter J. Seybolt, eds. Cultural Sociology of the Middle East, Asia, and Africa: An Encyclopedia. Washington, DC: Sage, 2012. 
Steffen, Tom A. "Why Communicate the Gospel through Stories." In Perspectives on the World Christian Movement, edited by Ralph D. Winter and Steven C. Hawthorne, 440-444. Pasadena, CA: William Carey Library, 2009.

Steffen, Tom A., and Lois McKinney Douglas. Encountering Missionary Life and Work: Preparing for Intercultural Ministry. Grand Rapids, MI: Baker Academic, 2008.

Sterile, Matthias. "From Cattle to Goats: The Transformation of East Pokot Pastoralism in Kenya." Nomadic Peoples 12, no. 1 (2008): 81-91.

Strauss, Robert, and Tom Steffen. "Change the Worldview, Change the World." Evangelical Missions Quarterly 45, no. 4 (October, 2009): 443-456.

Strauss, Steve. "Worldview Awareness." Christian Research Journal 28, no. 3 (2005): 13.

Sutton, Chuck. "The Challenge of Religious Pluralism." In Overcoming the World Missions Crisis: Thinking Strategically to Reach the World, edited by Russel L. Penny, 109-143. Grand Rapids, MI: Kregel, 2001.

Tablino, Paul. Christianity among Nomads: The Catholic Church in Northern Kenya. 2 vols. Nairobi, Kenya: Paulines Publications Africa, 2006.

Táíwò, Olúfémi. How Colonialism Preempted Modernity in Africa. Bloomington: Indiana University, 2010.

Tennent, Timothy C. Invitation to World Missions: A Trinitarian Missiology for the Twenty-first Century. Grand Rapids, MI: Kreg Academic and Professional, 2010.

Terry, J. O. "Chronological Bible Storying to Tribal and Nomadic Peoples." International Journal of Frontier Missions 14, no. 4 (Fall 1997): 1-15.

Trochim, William, James P. Donnelly, and Kanika Arora. Research Methods: The Essential Knowledge Base. Boston, MA: Cengage, 2015.

Tucker, Ruth. Not Ashamed: The Story of Jews for Jesus. Colorado Springs, CO: Multnomah Books, 1999.

Tulel, Irene Chepoisho. "Women and Peace-Building in Pastoral Conflicts: A Case Study of Pokot Women in Sigor Region of West Pokot County, 1984-2000.” Master's thesis, Nairobi University, 2013.

Umar, Abdi. "Resource Utilization, Conflict, and Insecurity in Pastoral Areas of Kenya." Paper presented at the USAID Seminar on Conflict Resolution in the Horn of Africa, Nairobi, Kenya, March 27-29, 1997. 
United Nations. "Chronic Marginalization, Fragmentation, Encroachment, Lack of Land Rights: Pastoralists in Africa among Poorest in World." United Nations Meetings Coverage and Press Releases, May 23, 2013. Accessed October 2, 2016. http://www.un.org/press/en/2013/hr5135.doc.htm.

United States Department of Health, Education and Welfare. The Belmont Report. April 18, 1979. Accessed September 2, 2016. http://www.hhs.gov/ohrp/regulations-andpolicy/belmont-report/.

United States Agency for International Development. "Understanding Nutrition Data and the Causes of Malnutrition in Kenya." Famine Early Warning Systems Network, September 2006.

Valle, Carlos A. Challenges of Communication. Delhi, India: ISPCK Press, 1995.

Van Engen, Charles, Nancy Thomas, and Robert Gallagher, eds. Footprints of God: A Narrative Theology of Mission. Eugene, OR: Wipf and Stock, 1999.

Van Rheenan, Gailyn. Communicating Christ in Animistic Contexts. Pasadena, CA: William Carey Library, 1991.

. Missions: Biblical Foundations and Contemporary Strategies. Grand Rapids, MI: Zondervan, 1996.

Van Steenbergen, Gerrit. "Translating 'Sin' in Pokoot: An Analysis of the Problem." The Bible Translator 4 no. 42 (October 1991): 431-437.

Vinay, Samuel, and Chris Sugden, eds. Mission as Transformation: A Theology of the Whole Gospel. Eugene, OR: Wipf, 2009.

Von Rad, Gerhard. Old Testament Theology: The Theology of Israel's Traditions. Louisville, KY: Westminster John Knox Press, 2001.

Wagner, Peter C. Confronting the Powers: How the New Testament Church Experienced the Power of Strategic-level Spiritual Warfare. Ventura, CA: Regal, 1996. 1980.

Stop the World: I Want to Get On. Pasadena, CA: William Carey Library

Strategies for Church Growth: Tools for Effective Mission and Evangelism. Eugene, OR: Wipf and Stock, 2010.

. Territorial Spirits: Practical Strategies for How to Crush the Enemy through Spiritual Warfare. Shippensburg, PA: Destiny, 2012.

Walls, Andrew F. The Missionary Movement in Christian History: Studies in the Transmission of Faith. Maryknoll, NY: Orbis Books, 2006. 
Walton, John H. The Lost World of Genesis One: Ancient Cosmology and the Origins Debate. Downers Grove, IL: InterVarsity, 2009.

Wanyonyi, Rafael. Interview by Author, Kitale, Kenya, June 2, 2014.

Webb, Eugene. Worldview and Mind: Religious Thought and Psychological Development. Columbia: University of Missouri, 2009.

Webster's Dictionary and Thesaurus. New Delhi, India: Allied Publishing Group, 2005. s.v. "Conservatism."

White, Ellen G. The Great Controversy. Nampa, ID: Pacific Press, 1996. . Ministry of Healing. Boise, ID: Pacific Press, 1942. . Prophets and Kings. Nampa, ID: Pacific Press, 1943. . The Story of Patriarchs and Prophets. Nampa, ID: Pacific Press, 1958.

Wilcox, Clifford. Robert Redfield and the Development of American Anthropology. Lanham, MD: Lexington Books, 2004.

The Willowbank Report: Lausanne Theology and Educational Group. "Changing Cultures and the Gospel." Third Way: Towards a Biblical Worldview 2, no. 11 (June 1978): 3-6.

Wilson, Sharon. "African Oral Tradition.” BlackandChristian.com, September 2003. Accessed March 17, 2016. http://www.blackandchristian.com/articles/academy /swilson-09-03.shtml.

Wolcott, Harry F. Ethnography: A Way of Seeing. New York: Altamira, 2008.

World Health Organization. "Eritrea: Map of the Migratory Routes of the Nomads in Northern and Southern Red Sea Zobas." May 30, 2007. Accessed November 27, 2016. http://reliefweb.int/report/eritrea/eritrea-map-migratory-routes-nomadsnorthern-and-southern-red-sea-zobas.

. Health Complications of Female Genital Mutilation.” World Health Organization. Accessed July 14, 2016. http://www.who.int/reproductivehealth /topics/fgm/health_consequences_fgm/en/.

World Mission Center. "Pokot." Accessed July 25, 2016. http://www.worldmissioncentre .com/index.html.

Wright, Christopher J. H. The Mission of God. Downers Grove, IL: InterVarsity, 2006. 
Wright, Nicholas T. The New Testament and the People of God. Minneapolis, MN: Fortress, 1992. 
VITA

\section{Personal Profile}

Name: $\quad$ Haron Nyamweya Matwetwe

Date of Birth: October 25, 1970.

Marital Status: Married to Deborah Mokeira Matwetwe.

\section{Educational Profile}

2000 B. A. Theology (University of East Africa-Baraton, Arusha Campus, Tanzania).

2006 M-Div (Andrews University).

2010 M. A. Religion (Andrews University).

2017 PhD Religion, World Mission Emphasis (Andrews University).

\section{Professional Profile}

1991 P1 Teacher, Kenya Teachers Service Commission.

$2001 \quad$ District Pastor, Kenya Coast Field.

2015 Adjunct Lecturer, World Missions, Adventist University of Africa. 